\title{
BIOLOGICAL PROCESSES IN THE WATER COLUMN \\ OF THE SOUTH ATLANTIC BIGHT
}

\author{
A Progress Report Submitted to \\ U.S. Department of Energy \\ CONTRACT DE-ASO9-76EV00936 \\ JuNE, 1979 TO JUNE, 1982
}

BY

SKIDAWAY INSTITUTE OF OCEANOGRAPHY

POST OfFICE BOX 13687

Savannah, Georgia 31406

Gustav-Adolf Paffenhöfer

AND

JAMES A, YODER

Co-Principal InVestigators

21 DeCEMber 1981 


\section{DISCLAIMER}

This report was prepared as an account of work sponsored by an agency of the United States Government. Neither the United States Government nor any agency Thereof, nor any of their employees, makes any warranty, express or implied, or assumes any legal liability or responsibility for the accuracy, completeness, or usefulness of any information, apparatus, product, or process disclosed, or represents that its use would not infringe privately owned rights. Reference herein to any specific commercial product, process, or service by trade name, trademark, manufacturer, or otherwise does not necessarily constitute or imply its endorsement, recommendation, or favoring by the United States Government or any agency thereof. The views and opinions of authors expressed herein do not necessarily state or reflect those of the United States Government or any agency thereof. 


\section{DISCLAIMER}

Portions of this document may be illegible in electronic image products. Images are produced from the best available original document. 


\section{The following pages are an exact representation of what is in the original document folder.}




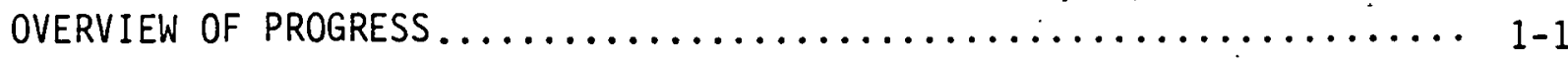

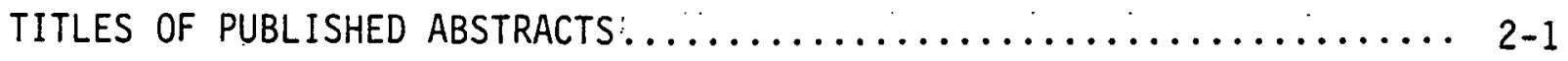

\section{MANUSCRIPTS}

Paffenhöfer, G.-A. and S.C. Knowles. 1979. Ecological Implications of fecal pellet size, production and consumption by copepods.

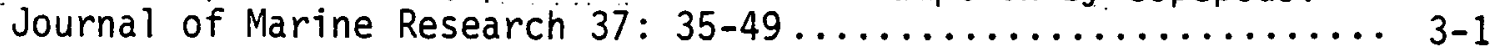

Bishop, S.S., J.A. Yoder and G.-A. Paffenhöfer. 1980. Phytoplankton and nutrient variability along a cross-shelf transect off Savannah, Georgia, U.S.A. Estuarine and Coastal Marine Science 11: $359-368$

Kim, H.H., C.R. McClain, L.R. Blaine, W.D. Hart, L.P. Atkinson and J.A. Yoder. 1980. Ocean chlorophyli studies from a U-2 aircraft platform. Journal of Geophysical Research 85: 3982-399C .. 5-1

Paffenhöfer, G.-A. 1980. Zooplankton distribution as related to summer hydrographic conditions in Onslow Bay, North Carolina. Bulleting of Marine Science $30: 819-832 \ldots \ldots \ldots \ldots \ldots \ldots \ldots \ldots \ldots \ldots \ldots \ldots \ldots .1$

Paffenhöfer, G.-A., D. Deibel, L.P. Atkinson and W.M. Dunstan. 1980. The relation of concentraion and size distribution of suspended particlate matter to hydrography in Onslow Bay, North Carolina. Deep-Sea Research 27A: 435-447

Pomeroy, L.R. and D. Deibel. 1980. Aggregation of organic matter by pelagic tunicates. Limnology and Oceanography 25: 643-652 ... 8-1

Hanson, R.B., K.R. Tenore, S. Bishop, C. Chamberlain, M.M. Pamatmat and J. Tietjen. 1981. Benthic enrichment in the Georgia Bight related to Gulf Stream intrusions and estuarine outwelling. Journal of Marine Research 39: 417-441

Hofmann, E.E., J.M. KI inck and G.-A. Paffenhöfer. 1981. Concentrations and vertical fluxed of zooplankton fecal pellets on a continental shelf. Marine Biology 61: 327-335 ............... 10-1

Yoder, J.A., L.P. Atkinson, J.0. Blanton, D.R. Deibel, D.W. Menzel and G.-A. Paffenhöfer. 1981. Plankton productivity and the distribution of fishes on the southeastern U.S. continental shelf. Sclence 214: 351-354... 
Yoder, J.A., L.P. Atkinson, T.N. Lee, H.H. Kim and C.R. McClain. 1981. Gulf Stream frontal eddies in forming phytoplankton patches on the outer southeastern shelf. Limnology and Oceanography 26: 1103-

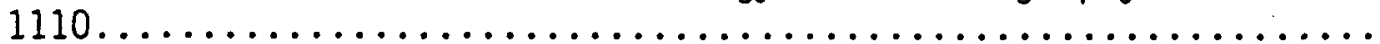

Deibel, D. In Press. Laboratory determined mortality, fecundity and growth rates of Thalia democratica Forskal and Dolioletta gegenbauri U1janin (Tunicata, Thaliacaea). Journal of Plankton Research. 13-1

Deibel, D. In Press. Laboratory measured grazing and ingestion rates of the salp, Thamia democratica Forskal and the doliolid, Dolioletta gegenbauri UTjanin (Tunicata, Thaliacea). Journal of Plank-

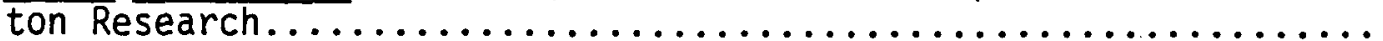

Gardner, W.S. and G.-A. Paffenhöfer. Nitrogen regeneration by the subtropical marine copepod Eucalanus pileatus. Submitted to Journal

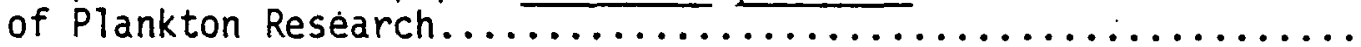

Paffenhöfer, G.-A. 1981. Calanoid copepod feeding: Grazind on small and large particles. Presented at Trophic Dynamics of Aquatic Ecosystems, AAAS Symposium, Toronto, Canada....................

Paffenhöfer, G.-A. In Press. Grazing by copepods in the Peru upwelling. Letter to the Editor, Deep-Sea Research.................

Bishop, S.S. and W.M. Dunstan. Effects of ionic copper on natural populations of phytoplankton grown in continuous culture. Submitted to Journal of Experimental Marine Biology and Ecology....

Yoder, J.A., L.P. Atkinson, S.S. Bishop, E.E. Hofmann and T.N. Lee. Effect of upwelling on phytoplankton productivity of the outer southeastern U.S. continental shelf. Submitted to Deep-Sea

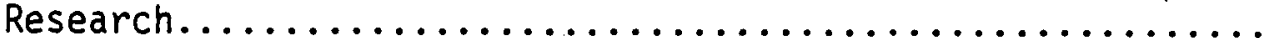

Paffenhöfer, G.-A. Vertical zooplankton distribution on the east Florida shelf in relation to temperature and food abundance.

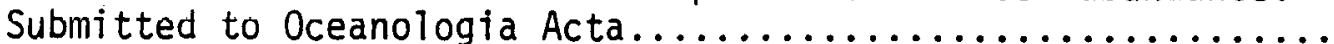


SECTION 1. OVERVIEW OF PROGRESS

\section{Phytoplankton Dynamics}

The following is a summary of what has been learned in the past three years covering phytoplankton dynamics of the southeastern shelf. Details are provided in the manuscripts that comprise sections $4,5,9,11,12,18$ and 19 of our Progress Report. All data collected prior to GABEX I (spring 1980) are included in these manuscripts as are the productivity measurements made during GABEX I. Other results obtained during GABEX I will be included in manuscripts that are presentiy in preparation. These include a manuscript that discusses surface chlorophyll distributions as measured by ship, by the Ocean Color Scanner (OCS) flown aboard a NASA U-2 aircraft, and by the Thematic Mapper Simulator (TMS) flown aboard a NASA C-130 aircraft. The latter is a prototype' of the radiometer that will be incorporated in the next LANDSAT satellite. A second manuscript in preparation focuses on shelfwide distribution of chlorophyll in relation to hydrography during the GABEX I study.

GABEX II (summer, 1981) samples are still being analyzed and these measurements will primarily be used to develop a water column $\mathrm{N}$ budget during the lifetime of a stranded intrusion. A second goal is to construct a time series of primary production during the development and collapse of a phytoplankton bloom within a stranded intrusion. Samples required to accomplish both of the above were collected during GABEX II. We expect that all GABEX II samples will be analyzed by May, 1982. A meeting will be held to discuss the preliminary results of GABEX II at the AGU/ASLO meeting in February, 1982, since most of the southeast-DOE group plans to attend this meeting. 
Summary of Phytoplankton Dynamics

1. Unlike the continental shelves north of Cape Hatteras, seasonal patterns in phytoplankton productivity and biomass are not very important on the southeastern shelf, if they exist at all (see section 4).

2. Aseasonal, episodic upwelling caused by disturbances of the Gulf Stream cyclonic front results in frequent, but short-lived, phytoplankton blooms. Upwelling is the major process controlling temporal and spatial changes in phytoplankton productivity and biomass on the middle and outer portions of the shelf (sèe sections $4,11,12$, and 19).

3. During winter and spring when the shelf is not stratified, upwelled waters are generally constrained to the outer portion of the shelf. During these months, phytoplankton blooms develop within the upwelled cold core of eddies as they propagate along the Gulf Stream cyclonic front. Strong upwelling can result in surface phytoplankton patches that cover more than $1000 \mathrm{~km}^{2}$. However, highest chlorophyll and primary production often occurs within subsurface intrusions of nutrient-rich upwelled waters (see section 12).

4. During summer when the shelf is stratified, subsurface intrusions of upwelled water move onto the shelf. These intrusions remain on the shelf long enough (greater than 1-2 weeks) for virtually all upwelled nitrate to be converted into phytoplankton biomass (see section 19).

5. Kecognition and elucidation of the upwelling process and 1 ts effect on phytoplankton productivity led to a new estimate of outer shelf primary productivity during winter and spring. This new estimate is 2-3 times higher than earlier estimates that did not take upwelling into account. Our esti- 
mate of "new" production is about $10 \times$ higher than those which did not account for the effect of upwelling. More than $90 \%$ of primary and "new" production on the outer shelf occurs during upwelling which occurs about $50 \%$ of the time (see section 19).

6. Our analysis of data collected during the 1950s shows that fish eggs and larvae are generally higher on the outer shelf (upwelling influenced) than the inner shelf.. The abundance of fish eggs and larvae on the outer shelf is independent of season which may in part reflect the aseasonality of primary production (manuscript in preparation, abstract submitted to Ocean Sciences 1982).

7. In conjunction with out NASA colleagues, we showed that muiti-spectral scanners flown at high altitudes can quantitatively determine chlorophyll gradients within ocean waters which contain only small amounts of non-biogenic particulate matter (see section 5 ).

8. In collaboration with others, we showed that benthic organisms are affected by high water column productivity of intrusions (see section 9).

9. We completed preliminary studies showing the effect of copper on phytoplankton of the nearshore region (see section 18 ).

\section{Zooplankton and Particulate Matter}

The results presented in the following 2 chapters are unpublished. Earlier obtained data on zooplankton and particulate matter have either been published or are in manuscript form (see Progress Report).

1. Our goal in 1979 was to determine abundance and distribution of nutrients, 
phyto- and zooplankton in upwelled water and describe processes associated with it. Throughout the 7 weekly cruises upwelling was limited and upwelled water masses were restricted to the outer shelf as shown for July 31st in Fig. 1a. Maximum nitrate concentrations in these intrusions ranged from 8.0 $1012.8 \mu$-moles. Surface waters and thermocline had no detectable amounts of nitrate. The water column was then stratified with a distinct thermocline (Fig. 1b). The concentrations of particulate matter available to zooplankton (2 to $100 \mu \mathrm{m}$ particle diameters) ranged from near $0.5 \mathrm{~mm}^{3} \cdot l^{-1}$ in surface waters to $5 \mathrm{~mm}^{3} \cdot \dot{\ell}^{-1}$ in the bottom intrusion (Fig. Ib).

Several of the zooplankton taxa which were found abundantily were in different stages of assemblage development (Figs. 1c and $d$ ): Concentrations of doliolids, the cladoceran Penilia avirostris, the cyclopoid Oncaea sp. and the calanoid Temora turbinata were lowest at St. 370 where water had just upwelled onto the shelf and the zooplankton therefore was in an early state of development. In contrast, zooplankton occurred in largest abundances at St. 374. The intruding water found there had moved onto the shelf earlier and was also of higher temperature. Zooplankton samples had been taken during the night covering with a pump the entire water column from near the surface to within $2 \mathrm{~m}$ of the sea floor. Sampling depths (upper mixed layer, thermocline and bottom mixed layer) were determined with temperature and depth sensors. At most times highest abundances were observed in the bottom layer and the thermocline. The relatively high concentrations in the upper mixed layer of the smaller copepods 0ithona, Oncaea, Paracalanus and the nauplii is related to the relatively high concentraions of particulate matter $\left(>0.5 \mathrm{~mm}^{3} \cdot \ell^{-1}\right)$. 
Characteristic of summer upwelling are amphioxus larvae (Branchiostoma caribaeum). Fish larvae:were observed in concentrations from 2 to $26 \cdot \mathrm{m}^{-3}$ throughout the water column considerably exceeding the concentrations on the west Florida shelf (Houde and Chitty 1976). The densities of nauplii which serve as food for early fish larvae ranged from 8 to 43 specimens $\cdot \ell^{-1}$ and are an underestimate as young nauplii of the small copepods should be able to pass to $30 \mu \mathrm{m}$ mesh employed in zooplankton pump collections (Beers and Stewart 1967). Nevertheless, the ambient concentrations of nauplii and small copepods should support the survival of 5 to $10 \%$ of hatched fish larvae (Houde 1978) which again should lead to the observed high concentrations of fish larvae on the outer shelf.

2. Our goal in 1981. was to determine the frequency and size of upwelled water masses between $29^{\circ}$ and $31^{\circ} 30^{\prime} \mathrm{N}$ and follow them for several weeks to determine rates and magnitudes of phyto- and zooplankton for development. We achieved this through onshore-offshore transects and standard hydrographic methods, among them the distribution of temperature and particulate matter in the range from 2 to $120 \mu m$ dianeter.

During mid-July we observed upwelling along the shelf break but no distinct stranding. Particle measurements indicated high concentraions of large particles off Jacksonville (Fig, 2a), and high concentrations $\left(>\mathrm{mm}^{3} \cdot \ell^{-1}\right)$ over most of the shelf. One week later the upwelling had moved onshore as observed by temperature, and by particle measurements (Fig. 2b). The particle size spectra hardly changed from July 13-16 to July 22-23: One week later (Fig. 2c) a new upwelling was observed by temperature; yet we could follow the "old" intru- 
sion using particle concentraion. These high particle concentrations consisted mostly of large diatoms which cannot be eaten 3 by small copepods (Paffenhöfer et al., 1980). The "new" water observed on July 27-29 remained on the shelf for the following 3 weeks (Figs. 2d, e and f). High particle concentraions were observed near the $20^{\circ} \mathrm{C}$ isotherm and increased from near 3 to $7 \mathrm{~mm}^{3} \cdot \mathrm{l}^{-1}$, consisting mostly of the large diatom Guinardia flaccida. Part of this new intrusion had low concentrations of particles $\left(<0.5 \mathrm{~mm}^{3} \cdot l^{-1}\right)$ which is partly attributed to high concentrations of pelagic tunicates (doliolids) in that particular part of the upweiling. Zoopiankton samples taken at all stations through the entire water column are now being analyzed and additional hydrographic data are processed. A synthesis of all data should allow us to contruct a nitrogen budget for each observed intrusion.

\section{CITED LITERATURE}

Beers, J.R. and G.L. Stewart. 1967. Micro-zooplankton in the euphotic zone at five locations across the California Current. J. Fish. Res. Bd. Can. 24 : 2053-2068.

Houde, E.D. 1978. Critical food concentrations for larvae of three species of subtropical marine fishes. Bul1. Mar. Sci. 28: 395-411.

Houde, E.D. and N. Chitty. 1976. Seasonal abundance and distribution of zooplankton, fish eggs, and fish larvae in the eastern Gulf of Mexico, 197274. NOAA Tech. Rep. NMFS SSRF-701, 18 pp.

Paffenhöfer, G.-A., D. Deibel, L.P. Atkinson and W.M. Dunstan. 1980. The relation of concentration and size distribution of suspended particulate matter to hydrography in Onslow Bay, North Carolina. Deep-Sea Res. 27A: 435-447. 


\section{FIGURES}

Fig. 1a. Horizontal distribution of near bottom temperature off northeastern Florida: July 31, 1979.

Fig. 1b. Onshore-offshore transect of temperature and particle concentration $\left(\mathrm{mm}^{3} \cdot \mathrm{l}^{-1}\right)$ at $30^{0} 00^{\prime} \mathrm{N}$ on August 1 to $2,1979$.

Figs. Ic to d. Zooplankton abundance and vertical distribution at 3 stations on August 1 to 2, 1979. Light bars = Upper mixed layer; stippled bars $=$ Thermocline; dashed bars = Bottom layer (intrusion):

Figs. $2 a$ to $f$. Distribution of near bottom temperature and near bottom particle concentration $\left(\mathrm{mm}^{3} \cdot \ell^{-1}\right)$ on the southeastern continental shelf. 


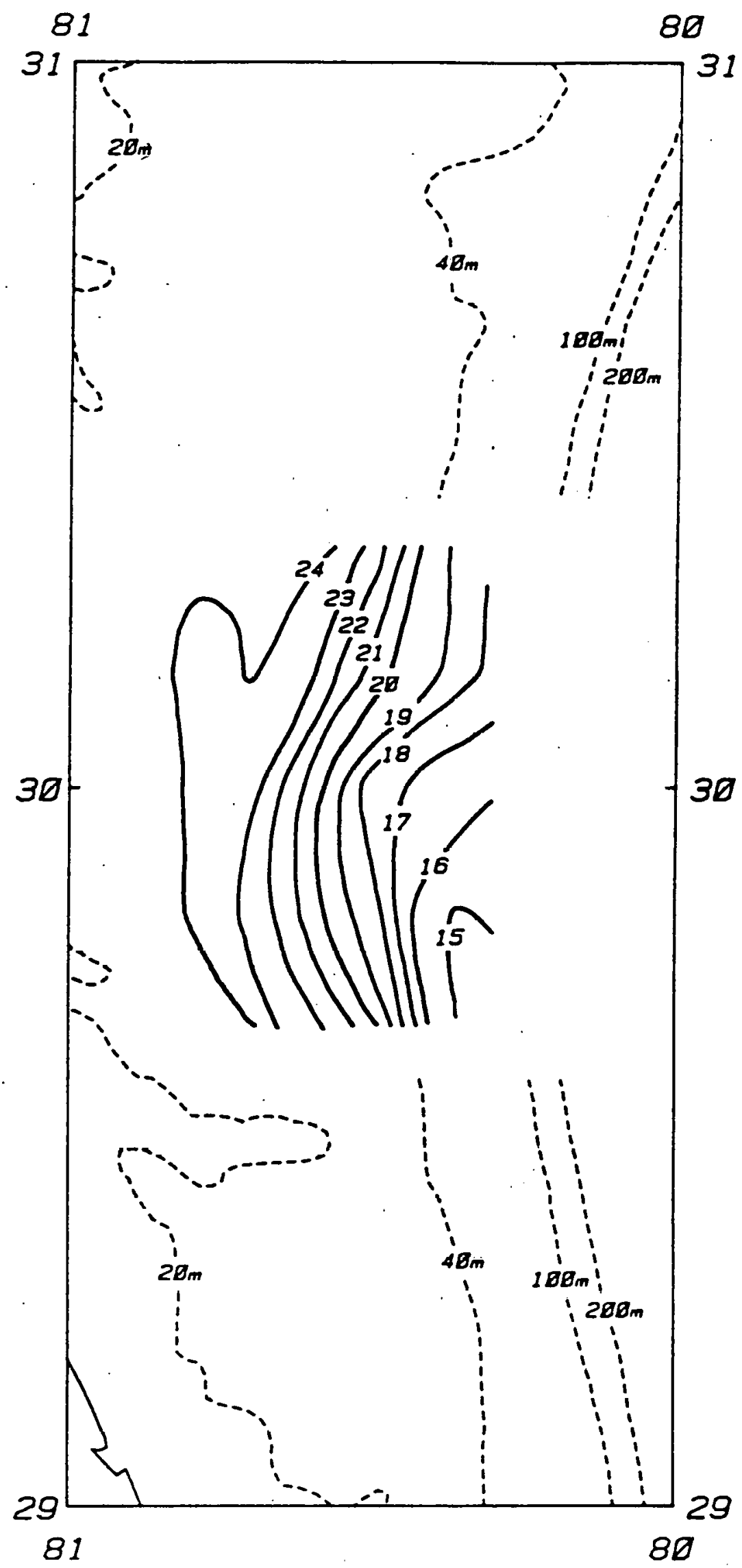

Fig. 1 a. Horizontal distribution of near bottom temperature off northeastern Florida: July 31, 1979. 
August 1-2, 1979 (Stations 370,372 and 374 )

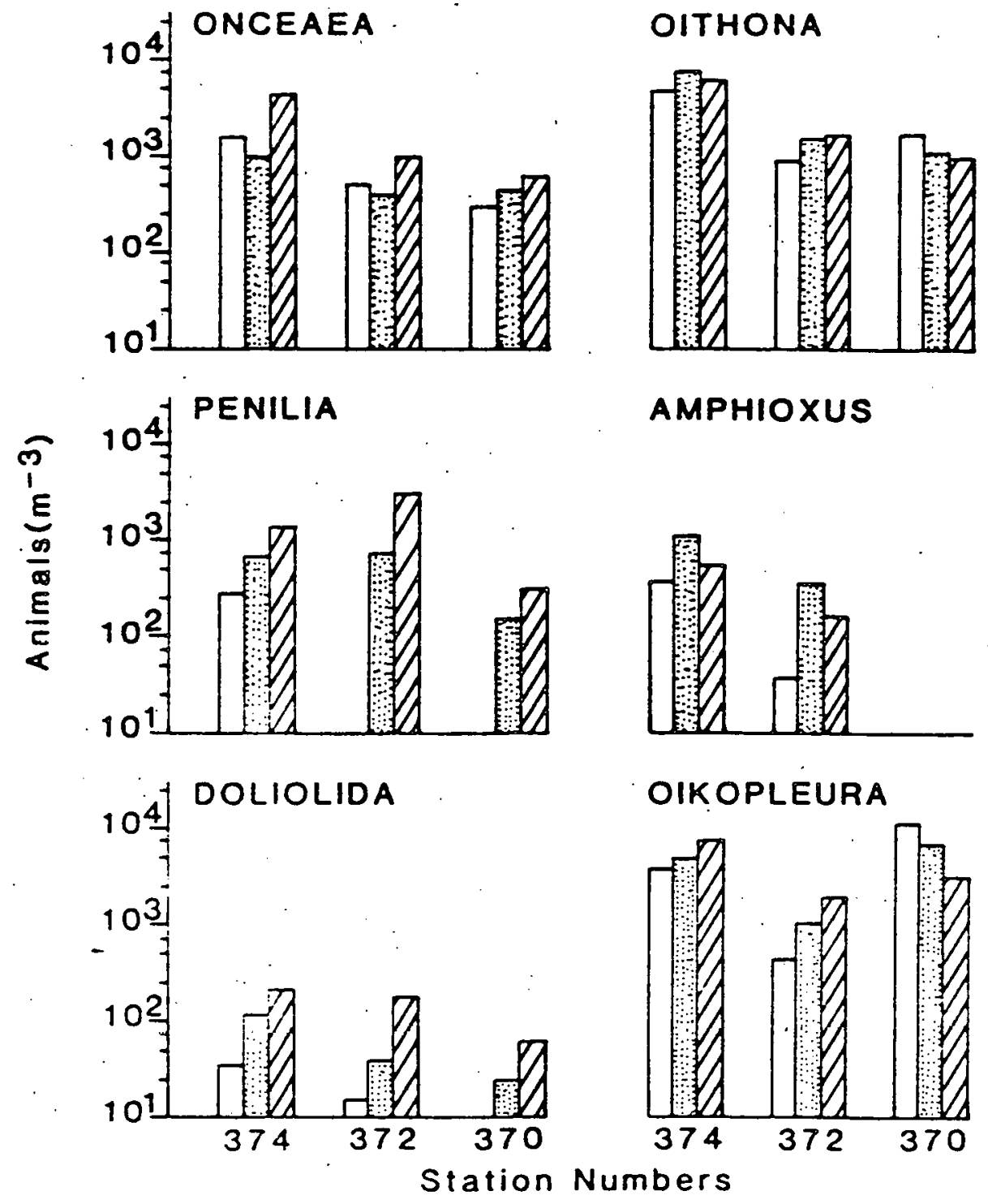

OITHONA

Fig. 1c. Zooplankton abundance and vertical distribution at 3 stations on August 1 to 2,1979 . Light bars = Upper mixed layer; stippled bars = Thermocline; dashed bars = Bottom layer (intrusion). 

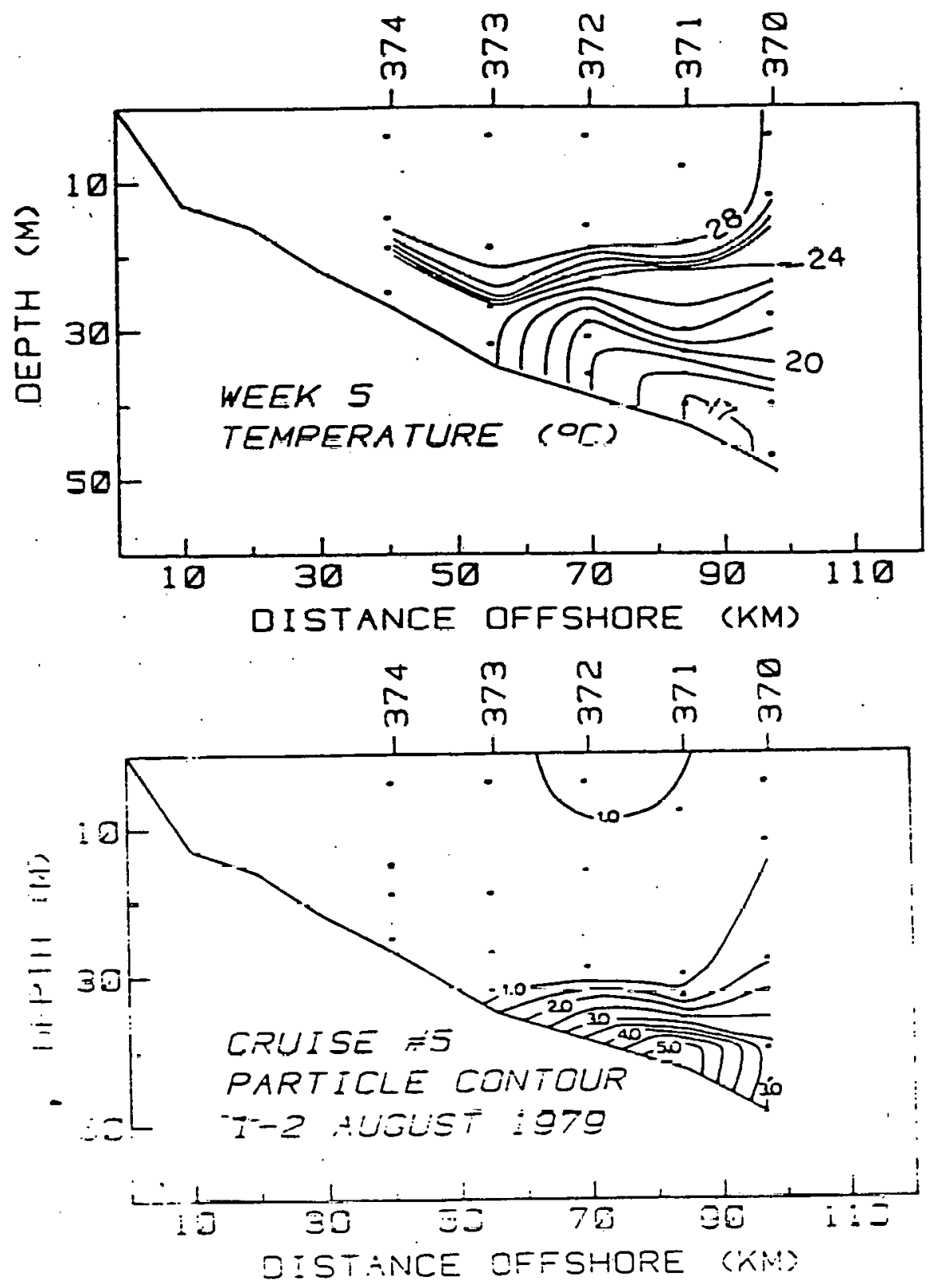

Fig. 1b. Onshore-offshore transect of temperature and particle concentration $\left(\mathrm{mm}^{3} \cdot \ell^{-1}\right)$ at $30^{\circ} 00^{\prime} \mathrm{N}$ on August 1 to 2 , 1979. 


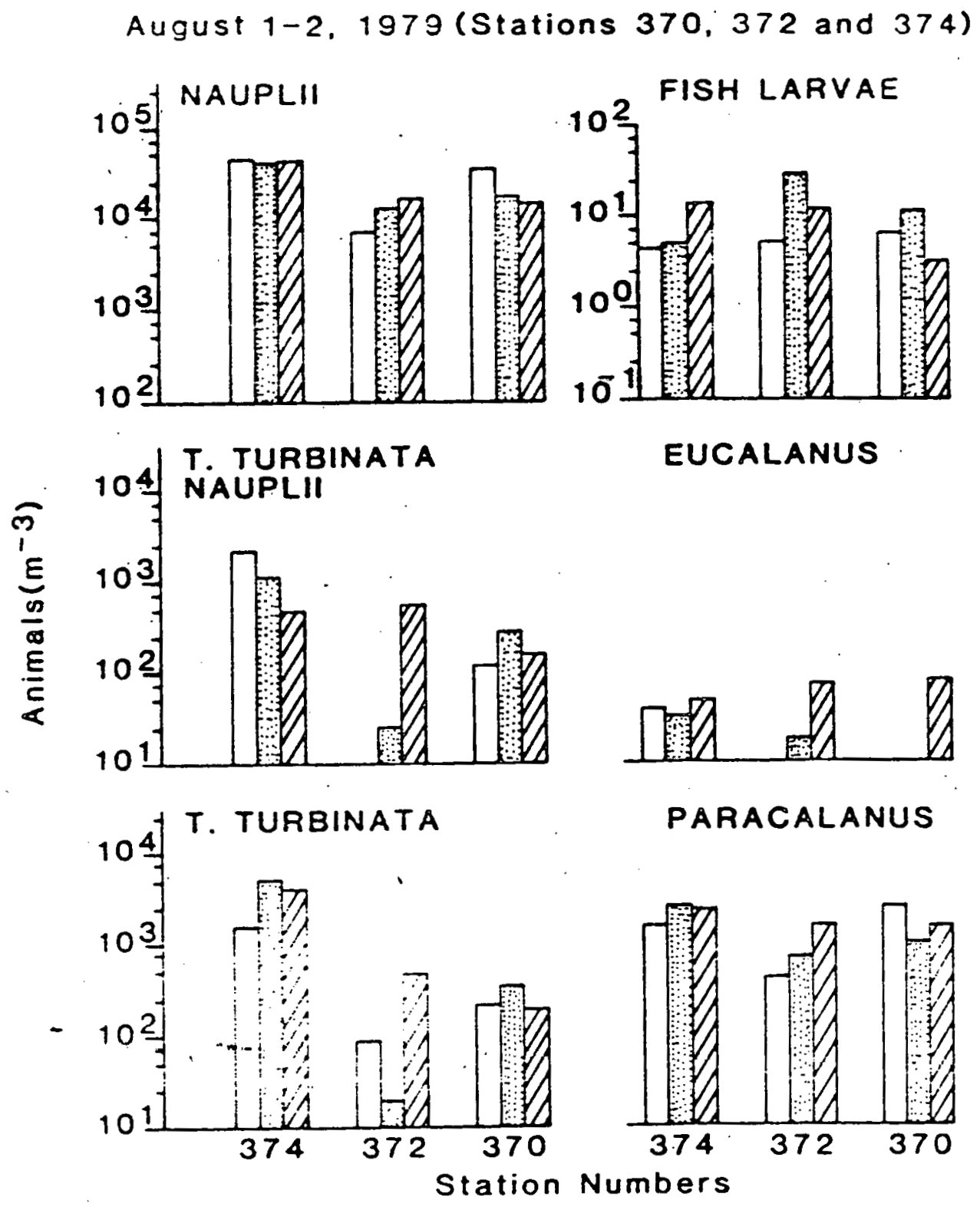

Fig. 1d. See Fig. 1c. 


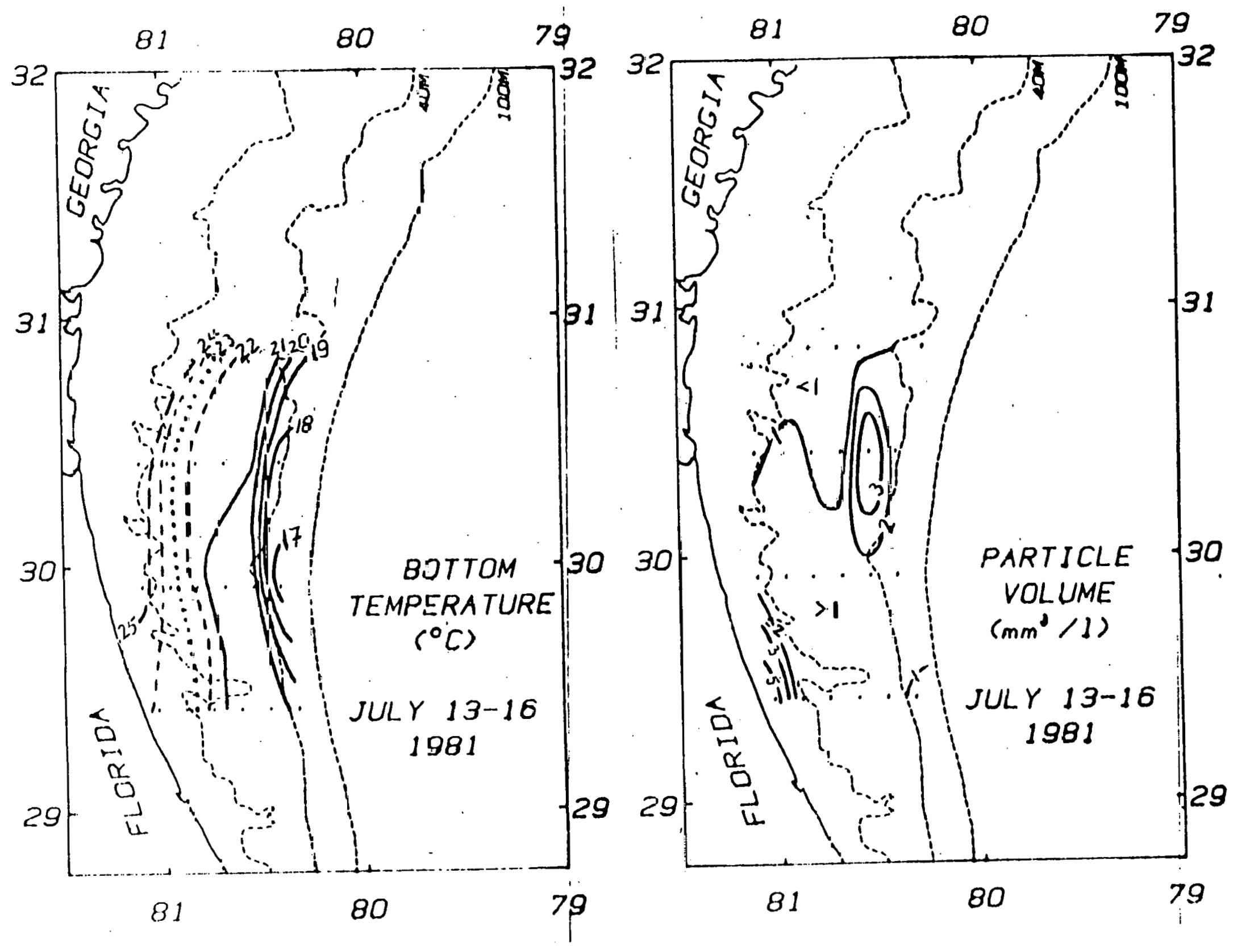

Fig. 2a. Distributior of near bottom temperature and near bottom particle concentration $\left(\mathrm{mm}^{3} \cdot \ell^{-1}\right)$ on the southeastern continental shelf. 


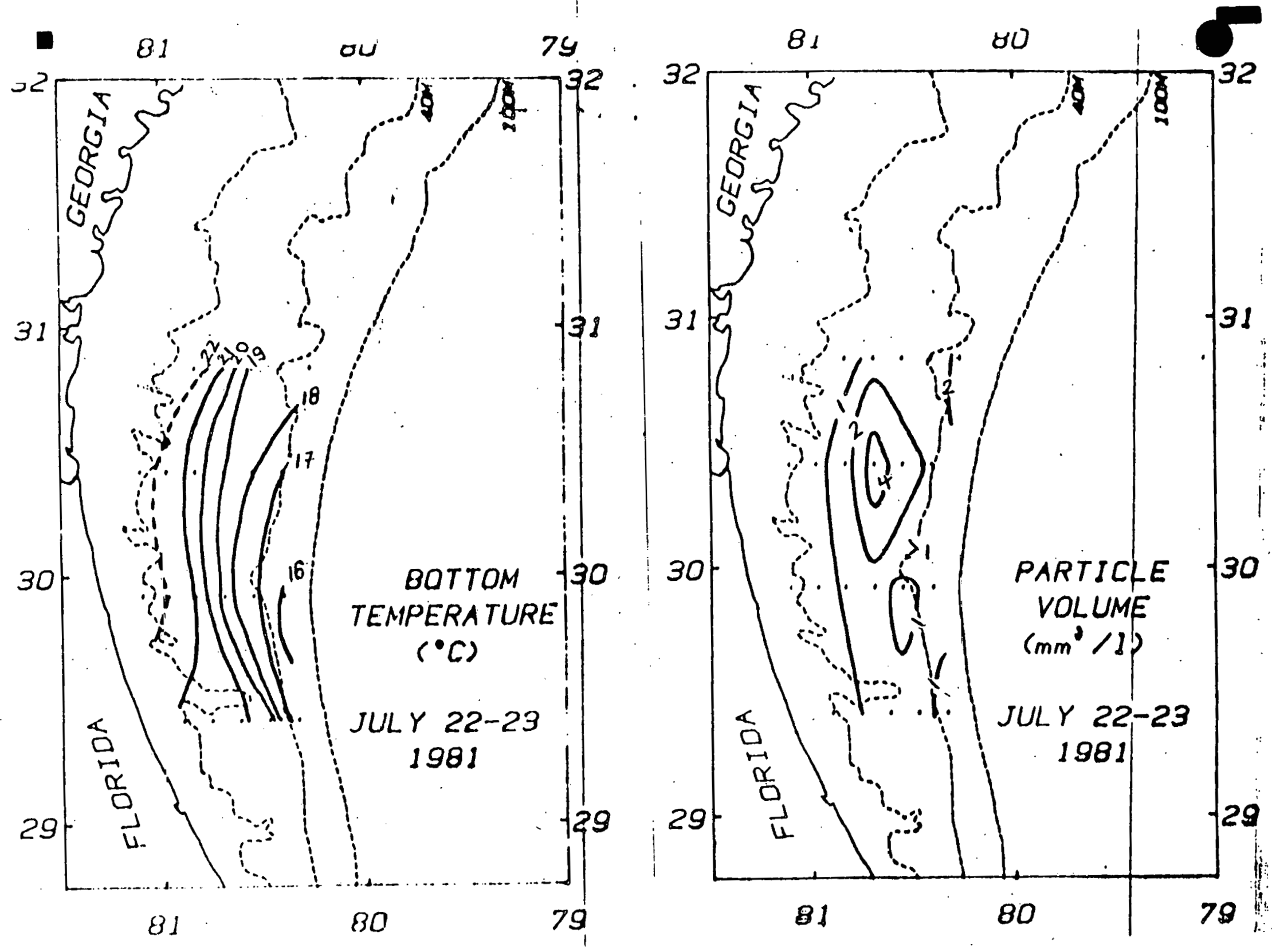

Fig. 2b. See Fig. 2a. 


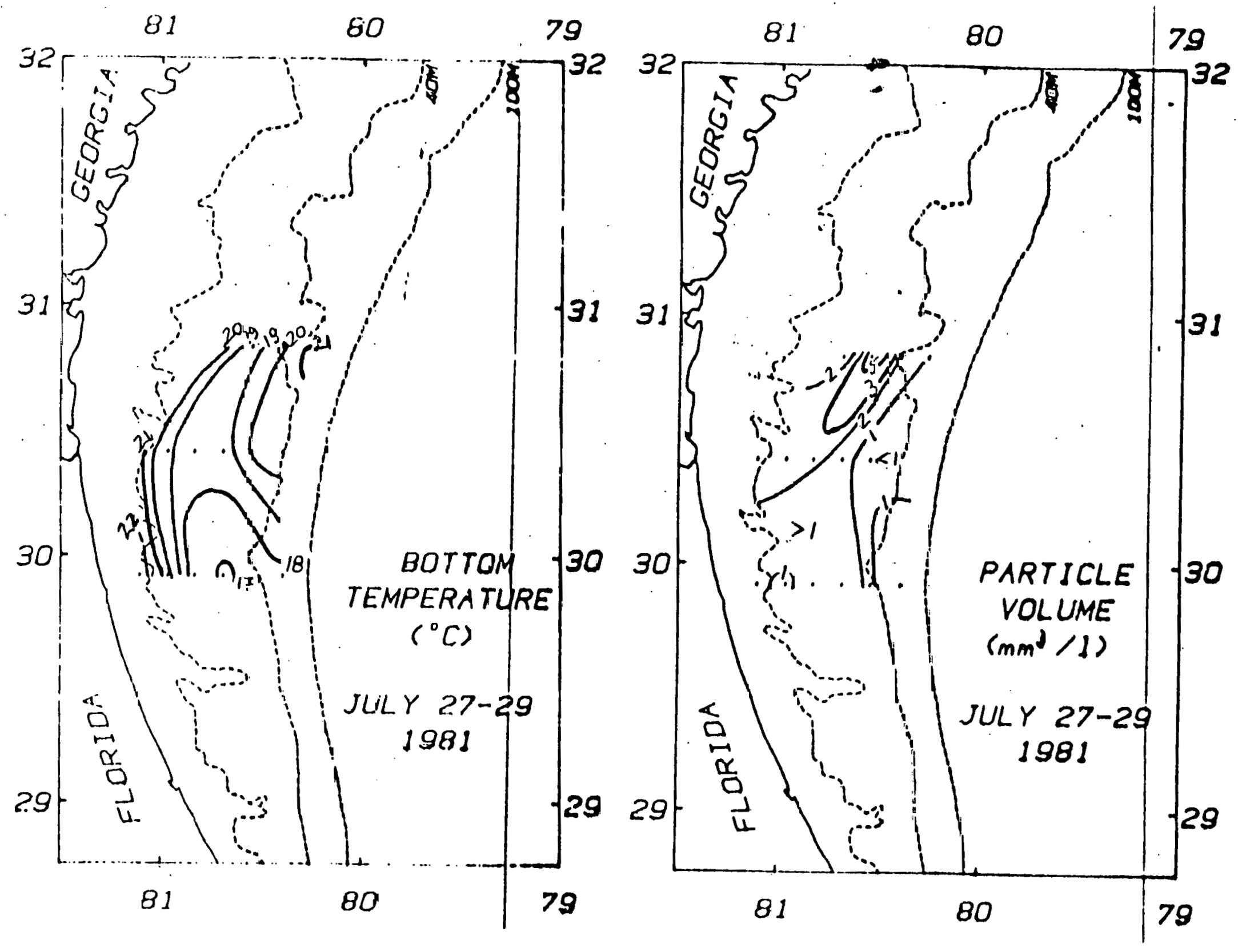

Fig. 2c. See Fig. 2a. 


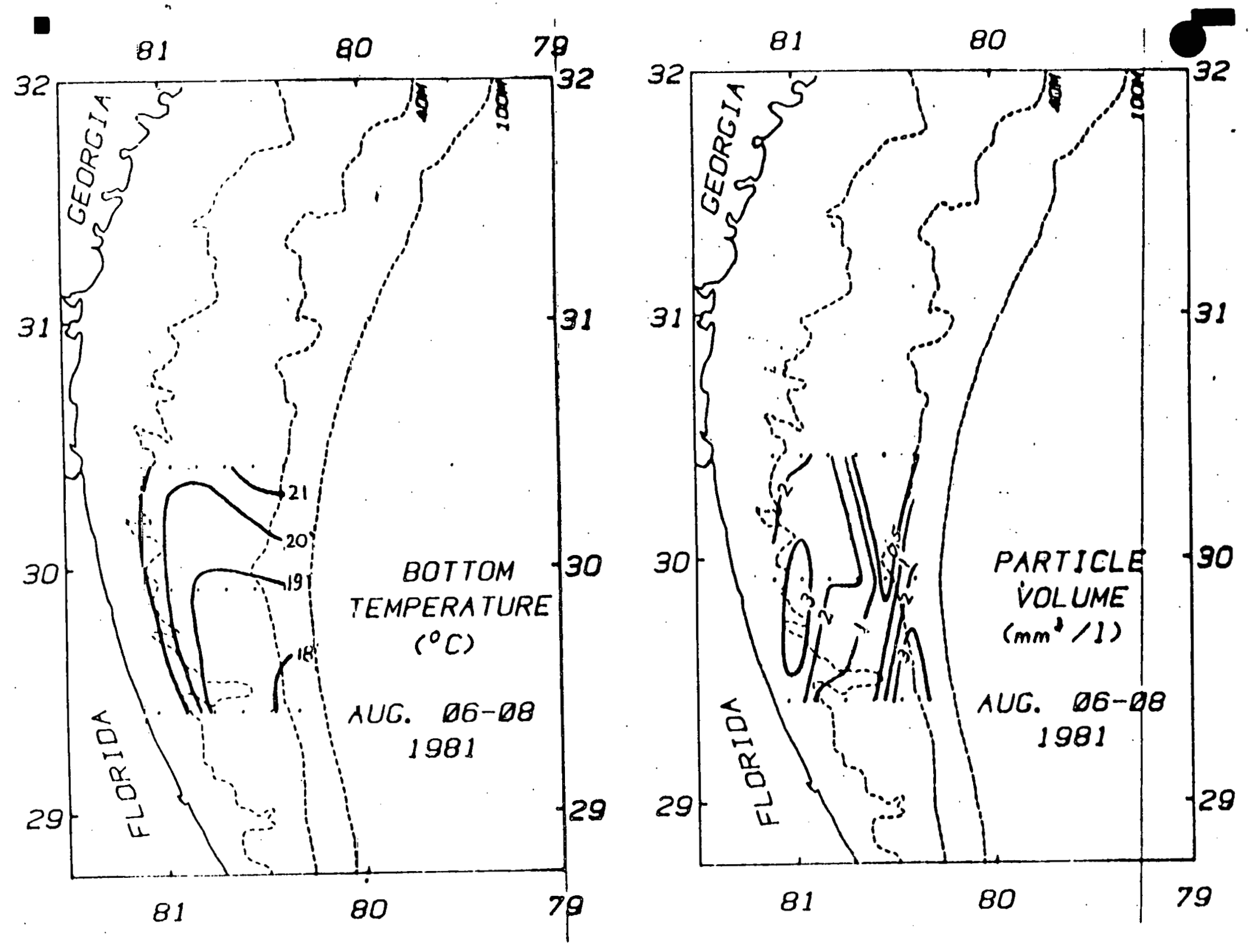

Fig. 2d. See Fig. 2a. 


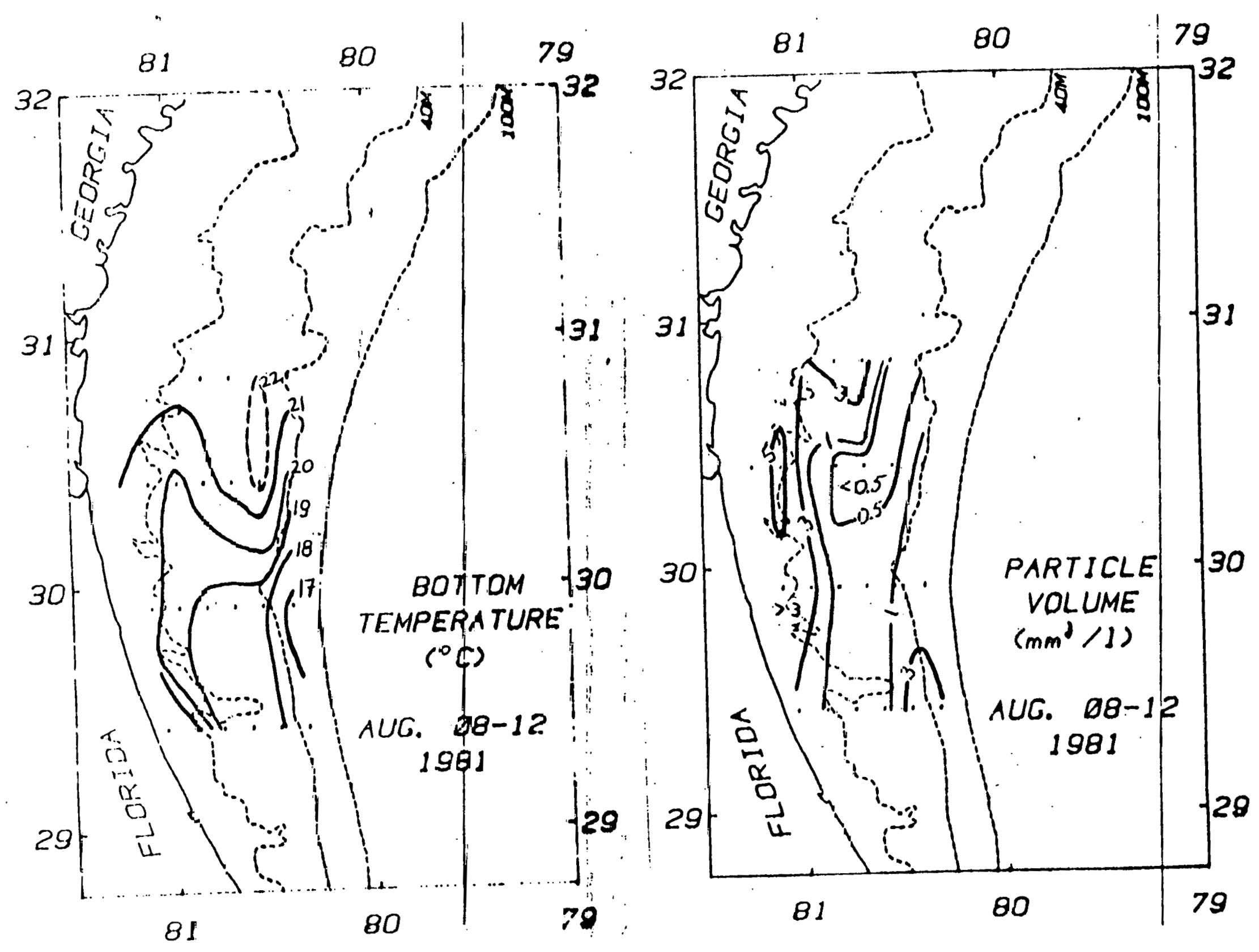

Fig. 2e. See Fig. 2a. 


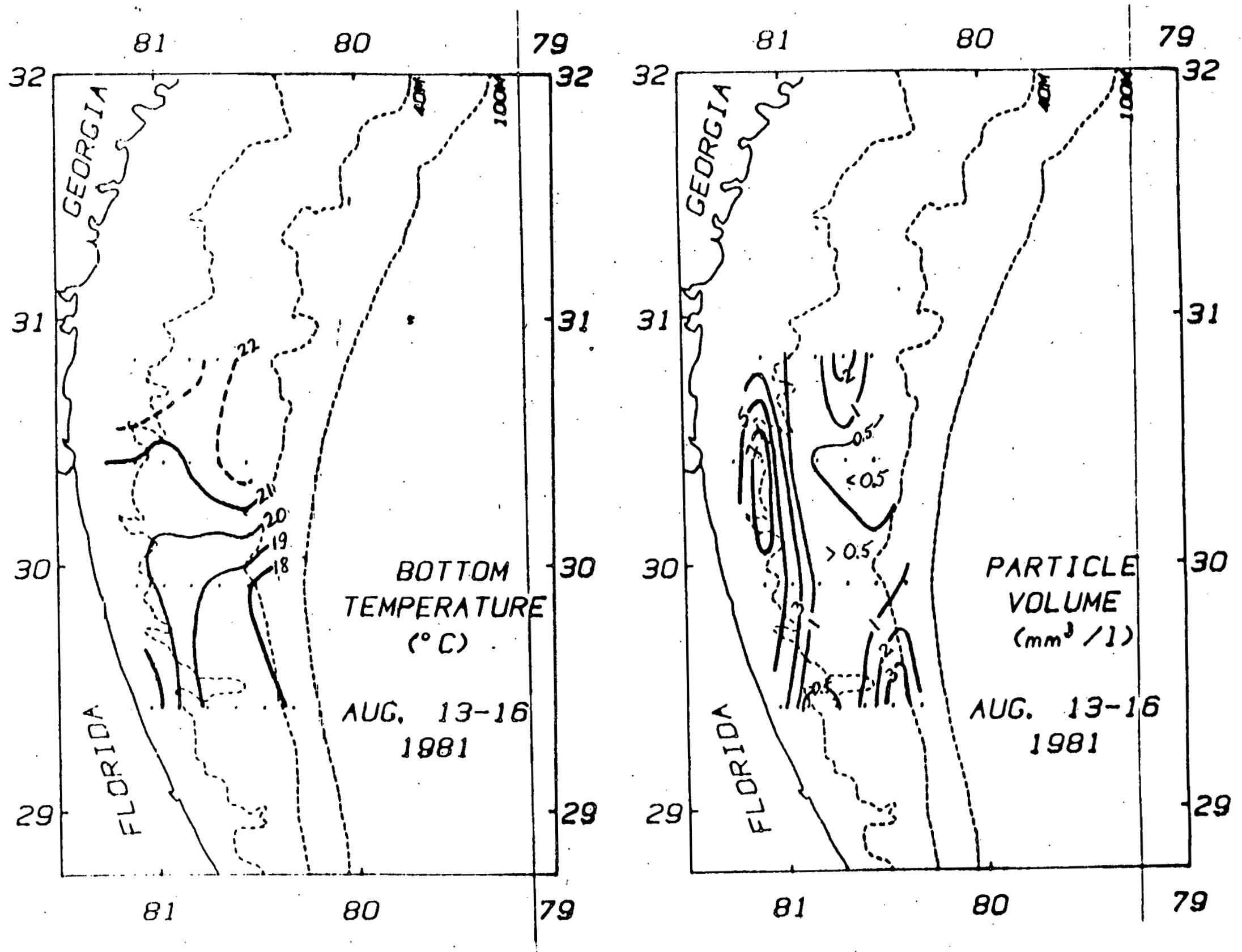

Fig. 2f. See Fig. 2a. 
SECTION 2. TITLES OF PUBLISHED ABSTRACTS

ASLO, June, 1979

Yoder, J.A. and S.S. Bishop. Upwelling events in the South Atlantic Bight: Phytoplankton response to an intrusion of nutrient-rich water onto the contintental shelf.

Atkinson, L.P., J.A. Yoder and T.N. Lee. Upwelling events in the South Atlantic Bight: Gulf Stream induced nutrient flux compared to other sources.

Paffenhöfer, G.-A. and D.C. Herring. Upwelling events in the South Atlantic Bight: Concentration and size distribution of particulate matter as related to zooplankton abundance and composition in intruding water masses.

Bishop, S.S. and W.M. Dunstan. Upwelling events in the South Atlantic Bight: The effects of Gulf Stream intrusions on the distribution of phytoplankton in Onslow Bay, North Carolina.

ASLO, January, 1980

Deibel, D. Thermohaline fronts and pelagic tunicate swarms.

IDOE Symposium on Coastal Upwelling, February, 1980

Atkinson, L.P., J.A. Yoder, H.H. Kim, C.R. McClain and T.N. Lee. Upwelling along the Gulf Stream front off the Southeastern coast of the United States,

Atkinson, L.P., J.O. Blanton, R.B. Hanson, T.N. Lee, D.W. Menzel, G.-A. Paffenhöfer, L.J. Pietrafesa, L.R. Pomeroy, K.R. Tenore, and J.A. Yoder. Upwelling off the Southeastern coast of the United States: An overview.

McClain, C.R., H.H. Kim, L.P. Atkinson and J.A. Yoder. High altitude remote sensing of the oceanic chlorophyll in frontal zones.

ASLO, June 1980

Bishop, S.S., S.R. Lasley, L.P. Atkinson and J.A. Yoder. Effect of eddyforced upwelling on nutrient and phytoplankton distribution near the shelf break in the South Atlantic Bight.

O'Malley, P.G., L.P. Atkinson and J.A. Yoder. The nitrogen pool of a mid= shelf intrusion. 
Singer, J.J., L.P. Atkinson, J.A. Yoder and T.N. Lee. Hydrographic observations of the Charleston Bump.

Paffenhöfer, G.-A. and S.C. Knowles. Omnivorous feeding of planktonic copepods.

Bishop, S.S. and W.M. Dunstan. Effects of ionic copper on natural populations of phytoplankton grown in continuous culture.

AGU, December 1980

Kim, H.H., C.R. McClain, W.D. Hart, L.P. Atkinson, and J.A. Yoder. Thermal and visible color expressions of an upwelling off the Gulf Stream.

ASLO, December, 1980

Yoder, J.A., L.P. Atkinson, S.S. Bishop, E.E. Hofmann, T.N. Lee, H.H. Kim and C.R. McClain. Effect of upwelling on primary productivity of the outer southeastern shelf.

Atkinson, L.P., J.A. Yoder and L.R. Pomeroy. Nutrient sources to the southeastern United States shelf waters: rivers, recycling, and the Gulf Stream.

ASLO/AGU, February, 1982

McClain, C.R., L.J. Pietrafesa, J.A. Yoder, H.H. Kim and L.P. Atkinson. On upwelling dynamics along the northern Florida-Georgia shelf. (Submitted)

Yoder, J.A. Distribution of fish eggs and larvae and their relation to upwelling regions on the southeastern U.S. continental shelf. (Submitted)

O'Malley, P.G., L.P. Atkinson and S.S. Bishop. Nutrient dynamics of summer Gulf. Stream intrusions off Florida and Georgia.. (Submitted)

Paffenhöfer, G.-A. Environmentally oriented copepod feeding studies. (Submitted)

Symposium on Biological Productivity of Continental Shelves. Kiel, March, 1982

Atkinson, L.P., J.A. Yoder and T.N. Lee. Gulf Stream associated upwelling off the southeastern United States and its effect on continental shelf nutrient concentrations and primary productivity. (In Press) 

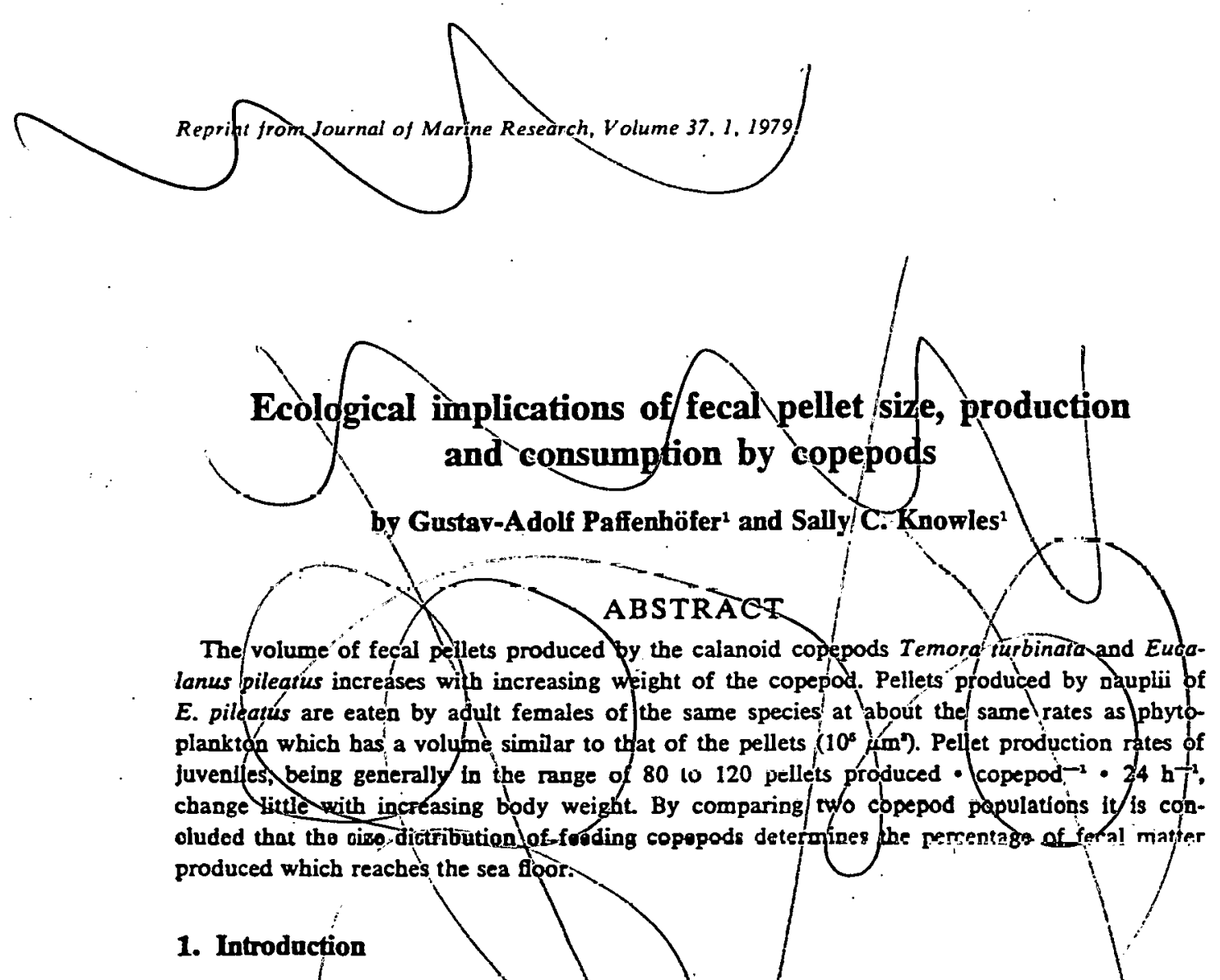

In the marine environment nopliving particulate organic matter (detritus) generally occurs in larger concentrations than living particulate matter (Krey, 1960; Poulet, 19776 ). Although the availability of detritus to zooplankton bas been frequently discussed, its quantitative impertance as a food source has been descuribed only twice (Petipa et al., 1970; Poulet, 1976). One constituent of detritus is zooplankton fecal màterial, the production of which has been measurèd numerous/imes, usually under unnatural conditions (Raymont and Gross, 1942; Marshatt and Orr, 1955; Corner et al., 1972; Gaudy, 1974; Honjo, 1976; Reeve and Whalter, 1977; Reeve et al., 1977; Grice et al., 1977; Honjo and Roman, 1978). Othor investiga tions have concentrated on determining the/rate of vertical transport of fecal pellets to the deep-sea pwith interest focysed mainly on fast-sinking $\left(>100\right.$ on $\left.\cdot 24 \mathrm{~h}^{-1}\right)$ large pellets (Swayda, 1969, 1971, Schader, 1971; Small and Fowlez, 1972; Honjo, 1976; Wiebe et al. 1976; Turner, 1977; Honjo and Roman, 1978).

Paffenhorer and Strlckland (1970) noled that Culanus helgolandicus dingests fecal pelyets. Davies et ul. (1973) concluded/that enpeponds "rework" fecal pellets besed on the fact that only 2 to $25 \%$ of the primary production was recovened as pellets in experimenta bags while one-third recovery was obtained outside the bags. Riley (1970) stated that "they (fecal pellets) mak be a source of particulate food that is

1. Skidaway Instimue of Deeanngraphy, P/O. Box 13687. Sayannah. Georgia/31406, U.S.A. 
TABLES 
Table I. Summary of the conditions of the laboratory experiments. All data are the arithmetic mean \pm standard error. $I=\underline{I}$. galbana, $P=\underline{P}$. trochoideum, $N G=$ no growth estimates were made.

\begin{tabular}{|c|c|c|c|c|c|c|}
\hline EXPERIMENT & STAGE & $\begin{array}{l}\text { Z0OID CONC } \\
\left(\mu g C \times 1^{-1}\right) \\
\left(\# \times 2.57^{-1}\right)\end{array}$ & $\begin{array}{l}\text { DURATION } \\
\text { (days) }\end{array}$ & N TEMP $\left({ }^{\circ} \mathrm{C}\right)$ & DIET & $\stackrel{5000 \mathrm{COl}}{\left(\mathrm{mm}^{3} \times 1-1\right)}$ \\
\hline A1 & $\frac{T}{\text { aggregates }}$ & $\begin{array}{l}190 \pm 29 \\
(29-9)\end{array}$ & 5 & $17.9 \pm 0.2$ & $I(N G)$ & $0.24 \pm 0.04$ \\
\hline $\mathrm{A} 2$ & & $\begin{array}{l}30.2 \pm 2.1 \\
(4-2)\end{array}$ & 3 & $18.6 \pm 0.5$ & I & $0.34 \pm 0.05$ \\
\hline \multirow[t]{2}{*}{ A3 } & & $\begin{array}{l}159 \pm 16 \\
(61-9)\end{array}$ & 8 & $20.6 \pm 0.2$ & $I+P$ & $0.38 \pm 0.07$ \\
\hline & & $\begin{array}{l}29.7 \pm 5.7 \\
(53-8)\end{array}$ & & . & $I(N G)$ & $0.48 \pm 0.04$ \\
\hline \multirow[t]{2}{*}{ A4 } & & $\begin{array}{l}87.8 \pm 13 \\
(64-3)\end{array}$ & 8 & $20.2 \pm 0.4$ & $I+P$ & $0.44 \pm 0.1$ \\
\hline & & $\begin{array}{l}75.8 \pm 14 \\
(120-20)\end{array}$ & & & $P(N G)$ & $0.16 \pm 0.3$ \\
\hline $\mathrm{Pl}$ & $\frac{\text { D. }}{\text { phorozooids }}$ & $\begin{array}{l}27.3 \pm 8.5 \\
(17-17)\end{array}$ & 3 & $18.6 \pm 0.4$ & 1 & $0.37 \pm 0$ \\
\hline P2 & & $\begin{array}{l}23.5 \pm 0.7 \\
(10-10)\end{array}$ & 8 & $20.1 \pm 0 . ?$ & $I+P$ & $0.43 \pm 0$. \\
\hline P3 & & $\begin{array}{l}17.4+0.5 \\
(15-12)\end{array}$ & 5 & $20.3 \pm 0.1$ & $1+P\left(N G_{2}\right)$ & $0.69 \pm 0$. \\
\hline G1 & $\frac{\text { D. }}{\text { gonozooids }}$ & $\begin{array}{l}25.5 \pm 3.0 \\
(10-3)\end{array}$ & 20 & $19.0 \pm 0.6$ & I & $0.40 \pm 0 . n^{n}$ \\
\hline \multirow[t]{2}{*}{62} & & $\begin{array}{l}55.0 \pm 0.0 \\
(6-2)\end{array}$ & $1 \%$ & $20.3 \pm 0.2$ & $I+P(N G)$ & $0.43 \pm 0.07$ \\
\hline & & $\begin{array}{l}55.0 \pm 0.0 \\
(4-2)\end{array}$ & & & $I+P(N G)$ & $0.34 \pm 0.08$ \\
\hline \multirow[t]{3}{*}{01} & $\frac{0}{00 z 00 i d s}$ & $\begin{array}{l}29.8 \pm 5.3 \\
(68-5)\end{array}$ & 20 & $19.4 \pm 0.9$ & $I(N G)$ & $0.34 \pm 0.03$ \\
\hline & . & $\begin{array}{l}33.2 \pm 4.6 \\
(68-4)\end{array}$ & & & $I(N G)$ & $0.32 \pm$ \\
\hline & & $\begin{array}{l}39.7 \pm 3.3 \\
(65-11)\end{array}$ & & & $I(H G)$ & $0.41 \pm 0.1$ \\
\hline
\end{tabular}


Table II. Arithmetic mean ( \pm standard error) mortality rates ( $\% \times$ $24 \mathrm{~h}^{-1}$ ) of $I$. democratica aggregates, and $\underline{D}$. gegenbauri gonozooids and oozooids. $n=$ the number of mortality rates which were pooled for the calculation of the means. * = a significant difference at the $95 \%$ confidence level. NS $=$ no significant difference at the $90 \%$ confidence level.

\begin{tabular}{cccc}
\hline STAGE & $\begin{array}{l}\text { MORTALITY RATE } \\
(\bar{X} \pm \text { SE })\end{array}$ & $n$ & $p$ \\
\hline $\begin{array}{c}\text { T. democratica } \\
\text { aggregate }\end{array}$ & $15 \pm 2.5$ & 27 & \\
D. gegenbauri & & & \\
gonozooid & $4.9 \pm 3.2$ & 17 & NS
\end{tabular}


Ta III Fecundity of the solitary stage of I. demc tica. SE = standard error of the mean. $(--)=$ data not available. SOL = solitary, and $A G=$ aggregate stages. There is no difference between seasons in the tota: number of aggregates released $x$ solitary ${ }^{-1}(p>0.3)$.

\begin{tabular}{|c|c|c|c|c|c|c|}
\hline Date & $\begin{array}{l}\text { Field } \\
\text { temp. } \\
\left({ }^{a} c\right)\end{array}$ & $\begin{array}{l}\text { SOL. } \\
\text { length } \\
(\mathrm{mm})\end{array}$ & $\begin{array}{l}\text { \# of chains } \\
\times \text { SOL }-1\end{array}$ & $\begin{array}{l}\text { \# of } A G \\
x \text { chain } \\
\end{array}$ & $\begin{array}{c}A G \\
\text { length } \\
(\mathrm{mm})\end{array}$ & $\begin{array}{l}\text { Total \# of } \\
A G \times S^{-1}\end{array}$ \\
\hline 12 Jan. 77 & 15.2 & $\cdots$ & 1 & 29 & $1.4-2.1$ & 29 \\
\hline 29 June 77 & 28.2 & $\begin{array}{l}8.2 \\
8.4\end{array}$ & $\begin{array}{l}1 \\
1\end{array}$ & $\begin{array}{l}62 \\
42\end{array}$ & -- & $\begin{array}{l}62 \\
42\end{array}$ \\
\hline 16 Sept. 77 & 29.3 & $\therefore$ & $\begin{array}{l}1 \\
1 \\
1 \\
1\end{array}$ & $\begin{array}{l}64 \\
21 \\
42 \\
33\end{array}$ & $\begin{array}{l}2.1 \\
1.1 \\
1.4 \\
1.4\end{array}$ & $\begin{array}{l}64 \\
21 \\
42 \\
33\end{array}$ \\
\hline 6 oct. 77 & 26.0 & $\begin{array}{l}-- \\
\cdots \\
\cdots-\end{array}$ & 2 & $\begin{array}{l}85 \\
35 \\
64\end{array}$ & $\cdots$ & $\begin{array}{r}120 \\
64\end{array}$ \\
\hline 12 Jan. 73 & 19.9 & -- & 2 & $\begin{array}{l}44 \\
41\end{array}$ & $\cdots$ & 88 \\
\hline 28 Jan. 78 & 18.3 & $\begin{array}{l}6.2 \\
6.2\end{array}$ & $\begin{array}{l}1 \\
1\end{array}$ & $\begin{array}{l}32 \\
50\end{array}$ & $\cdots$ & $\begin{array}{l}32 \\
50\end{array}$ \\
\hline Range & $\begin{array}{l}15.2- \\
29.3\end{array}$ & $\begin{array}{l}5.2- \\
8.4\end{array}$ & $1-2$ & $\begin{array}{l}21- \\
85\end{array}$ & $1.1-2.1$ & $\begin{array}{l}21- \\
120\end{array}$ \\
\hline $\bar{X} \pm S E$ & -- & - & -- & $46 \pm 5$ & $\ldots$ & $54 \pm 8$ \\
\hline
\end{tabular}


Table IV. Fecundity of the gonozooid stage of $\underline{\mathbb{D}}$. gegenbaurt. SE a standard error of the mean. (---) = data not avallable. $G Z$ = gonozoold stage. There is no effect of diet or season on the number of larvae released $x$ gonozooid $(p>0.20)$. The larvae are significantly shorter during March and April ( $p<0.01)$.

\begin{tabular}{|c|c|c|c|c|c|}
\hline Date & Food & \# of GZ & $\underset{\substack{G Z \\
\text { length } \\
(\text { nin) }}}{ }$ & $\#$ of larvae & $\begin{array}{l}\text { Larval } \\
\text { length } \\
(\mathrm{mm})\end{array}$ \\
\hline 18 Mar. 77 & I. galbana & $\begin{array}{l}7 \\
4 \\
3 \\
3 \\
3 \\
5\end{array}$ & $\begin{array}{l}3.7-3.9 \\
4.8-5.2 \\
4.9-5.6 \\
4.7-5.7 \\
5.8-6.2 \\
4.9-5.0\end{array}$ & $\begin{array}{l}2 \\
4 \\
4 \\
6 \\
4 \\
5\end{array}$ & $\begin{array}{c}\cdots \\
\cdots \\
0.6 \pm 0 \\
\cdots \\
0.6 \pm 0\end{array}$ \\
\hline 1 Apr. 77 & I. gulbana & 4 & $3.9-6.2$ & 3 & $0.6 \pm 0$ \\
\hline 26 Aug. 77 & $\begin{array}{l}\text { I. galbana }+ \\
\underline{\text { trochoideum }}\end{array}$ & 2 &.- & 4 & $1.2 \pm 0.3$ \\
\hline 1 Sept. 77 & $\underline{\underline{p}} \cdot \frac{\text { galbana }+}{\text { trochoideum }}$ & 1 & 6.2 & 2 & $1.0 \pm 0$ \\
\hline Range & $\therefore$ & -- & $3.7-6.2$ & $2-6$ & $0.6-1.2$ \\
\hline $\bar{x} \pm S E$ & -- & -- & -- & $3.8 \pm 0.1$ & - \\
\hline
\end{tabular}


Table V. Daily growth coefficients $\left(k \times 24 \mathrm{~h}^{-1}\right)$ in contiguous weight classes ( $\mu \mathrm{g} C$ ) for I. democratica aggregates (experiments $A 3$ and $A 4$ ) and $\underline{D}$. gegenbauri gonozooids (experiment G1). (---) = no coefficients available for zooids of that weight class. SE = standard error of the mean. There is no difference between the mean coefficients of the three experiments $(p>0.25)$.

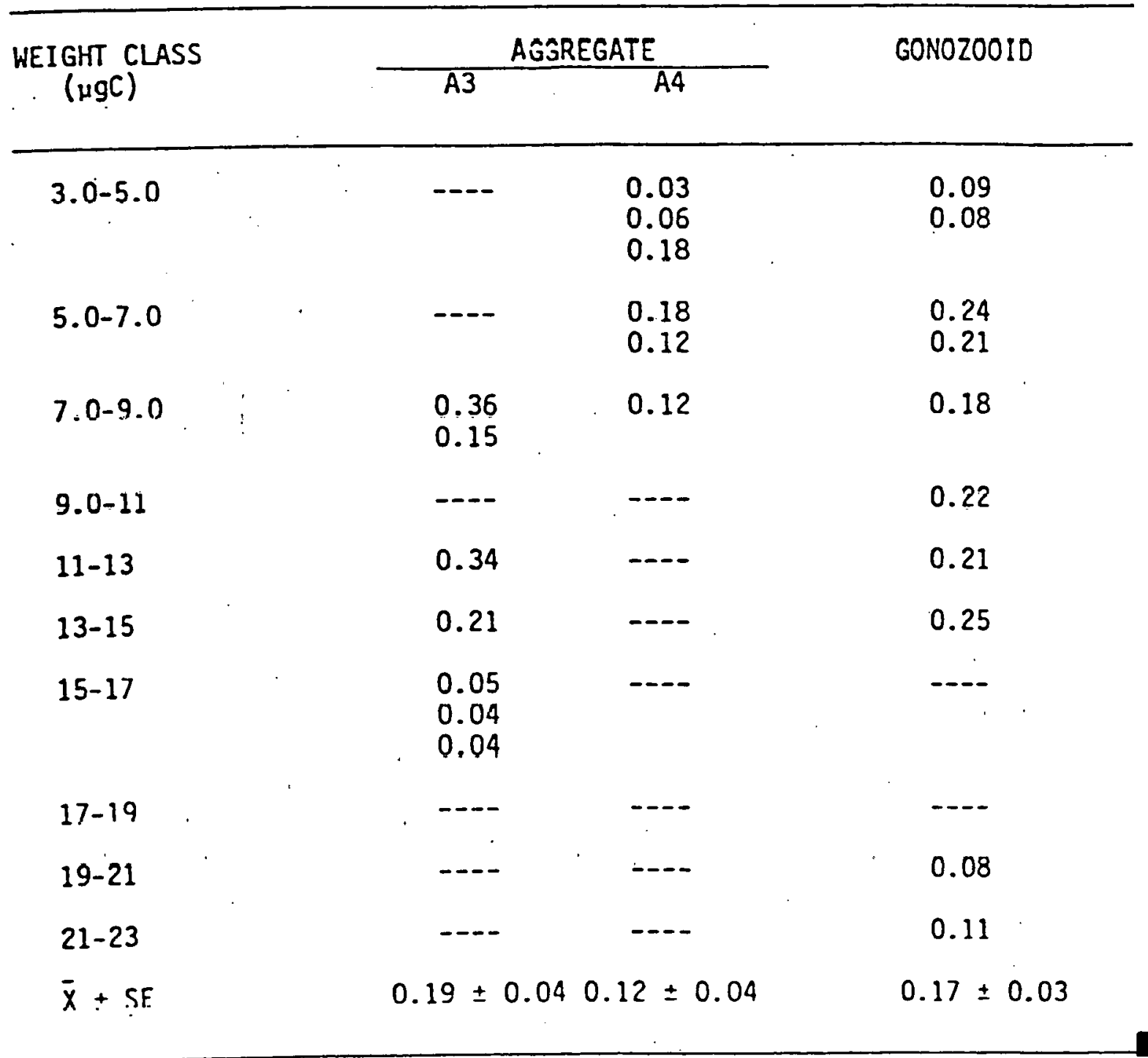


Table VI. Fecundity of the solitary stage of $I$. democratica. $S E=$ standard error of the mean. $(--)$ Data not avallable

\begin{tabular}{|c|c|c|c|c|c|c|c|}
\hline Source & $\begin{array}{l}\text { Field } \\
\text { temp. } \\
\left({ }^{\circ} \mathrm{C}\right)\end{array}$ & $\begin{array}{l}\text { SOL } \\
\text { leng=h } \\
\text { (mml }\end{array}$ & $\begin{array}{c}\text { \# of chains } \\
x \\
\text { SOL-1 }\end{array}$ & $\begin{array}{l}\text { \# of } \\
\text { chai } \\
\text { range }\end{array}$ & $\frac{-1}{(\bar{X})^{1} \times \mathrm{SE}}$ & $\begin{array}{c}A G \\
\text { length } \\
\text { (mm) }\end{array}$ & $\begin{array}{l}\text { Total \# of } A G \\
\frac{X S O L^{-1}}{\text { range }(X) \pm S E}\end{array}$ \\
\hline This report & $15.2-29.3$ & $6.2-8.4$ & $1-2$ & $21-85$ & $45 \pm 5$ & $1.1-2.1$ & $21-120 \quad 54 \pm 8$ \\
\hline $\begin{array}{c}\text { Braconnot, } \\
1953\end{array}$ & 14 & $10-12$ & 2 & - & $32 \pm 4$ & - & $71 \pm 13$ \\
\hline Heron, 1972a & -- & 10 & & $20-80$ & - & $1.5-2.0$ & - \\
\hline
\end{tabular}


Table VII Estinated gereration tine of I. democratica. Data are the arithmetic mean \pm standard error.

\begin{tabular}{|c|c|c|c|c|c|}
\hline & $\begin{array}{l}\text { Length } \\
\text { at birth } \\
(\mathrm{mm})\end{array}$ & $\begin{array}{l}\text { Length at } \\
\text { birth of } \\
\text { first progeny } \\
(\mathrm{m} \text { ) }\end{array}$ & $\begin{array}{l}\text { Weight } \\
\text { at birth } \\
(\mu g C)\end{array}$ & $\begin{array}{c}\text { Weight at } \\
\text { birtt. of } \\
\text { first Frogeny } \\
\text { (uCC) }\end{array}$ & $\begin{array}{c}\text { Time from } \\
\text { initial to } \\
\text { final weight } \\
\text { (days) }\end{array}$ \\
\hline SOLITARY & $c .8 \pm 0.1$ & $7.3 \pm 0.3$ & 7.0 & 52 & $11-13$ \\
\hline AGGREGATE & $1.6 \pm 0.1$ & 5.0 (estimate) & 2.1 & 23 & $8-10$ \\
\hline GENERATION TIME & • & & & . & $19-23$ \\
\hline
\end{tabular}


Table VIII Estimated generation time of $\underline{D}$. gegenbauri. Data are the arithmetic mean \pm standard error.

\begin{tabular}{|c|c|c|c|c|c|}
\hline . & $\begin{array}{l}\text { length } \\
\text { at birth } \\
(\mathrm{mm})\end{array}$ & $\begin{array}{l}\text { Length at } \\
\text { birth of } \\
\text { first progeny } \\
(\mathrm{mm})\end{array}$ & $\begin{array}{l}\text { Weight } \\
\text { at birth } \\
(\mu g C)\end{array}$ & $\begin{array}{c}\text { Weight at } \\
\text { birth of } \\
\text { first progeny } \\
\text { (ugC) }\end{array}$ & $\begin{array}{l}\text { Time from } \\
\text { initial to } \\
\text { final weight } \\
\text { (days) }\end{array}$ \\
\hline 0020010 & $0.8 \pm 0.1$ & 8.0 (estimate) & 0.5 & 63 & $13-15$ \\
\hline PHOROZOOID & 2.5 (est.) & $7.5 \pm 1.0$ & 5.5 & 55 & $8-12$ \\
\hline GONOZOOID & $0.8 \pm 0.1$ & $5.1 \pm 0.1$ & 0.5 & 24 & $8-14$ \\
\hline GENERATION TIME & & & & & $29-41$ \\
\hline
\end{tabular}




\section{FIGURE LEGENDS}

Figure 1. Weight versus length for $I$. democratica aggregates. Each point is a mean of measurements of 2 to 5 zooids. The power function is $W=0.8 L^{2.1}\left(n=49, R^{2}=79 \%, p<0.001\right)$. The equation was calculated by the natural $\log$ transform method of Draper and Smith (1966).

Figure 2. Mean ( \pm standard error) daily mortality rate versus time since release for $\underline{I}$. democratica aggregates $(\Xi)$ and ali $\underline{D}$. gegenbauri zooids $(x)$. Since there was no difference between gonozooid and oozooir mean mortality rates, these data were pooled. 2 to 4 observations were pooled for the calculation of each aggregate mean, and 3 to 5 observatic..j for each doliolid mean. Doliolid mortality is time independent ( $p>0.25$ ) The aggregate regression equation is:

$$
M R=2.44 T+0.85\left(n=28, R^{2}=20 \%, p<0.05\right) .
$$

Figure 3. Zooid weight versus time since release. Weight was plotted only rur those populations with less than $15 \%$ daily mortality.

(-) - I. democratica aggregates (experiment $A 3, I+P=T a b l e ~ 1) . \log _{10}$ $0.07 T+0.72\left(n=8, R^{2}=90 \%, p<0.001\right)$.

$(0)=I$. democratica aggregates (experiment A4, I $+P-$ Table 1). $\log _{10^{n}}=$ $0.06 T+0.45\left(n=7, R^{2}=96 \%, p<0.001\right)$.

$(x)=D$. gegenbauri gonozooids (experiment GI, I - Table 1 ). $\log _{10} W=$ $0.06 T+0.35\left(n=11, R^{2}=96 \%, p<0.001\right)$. 


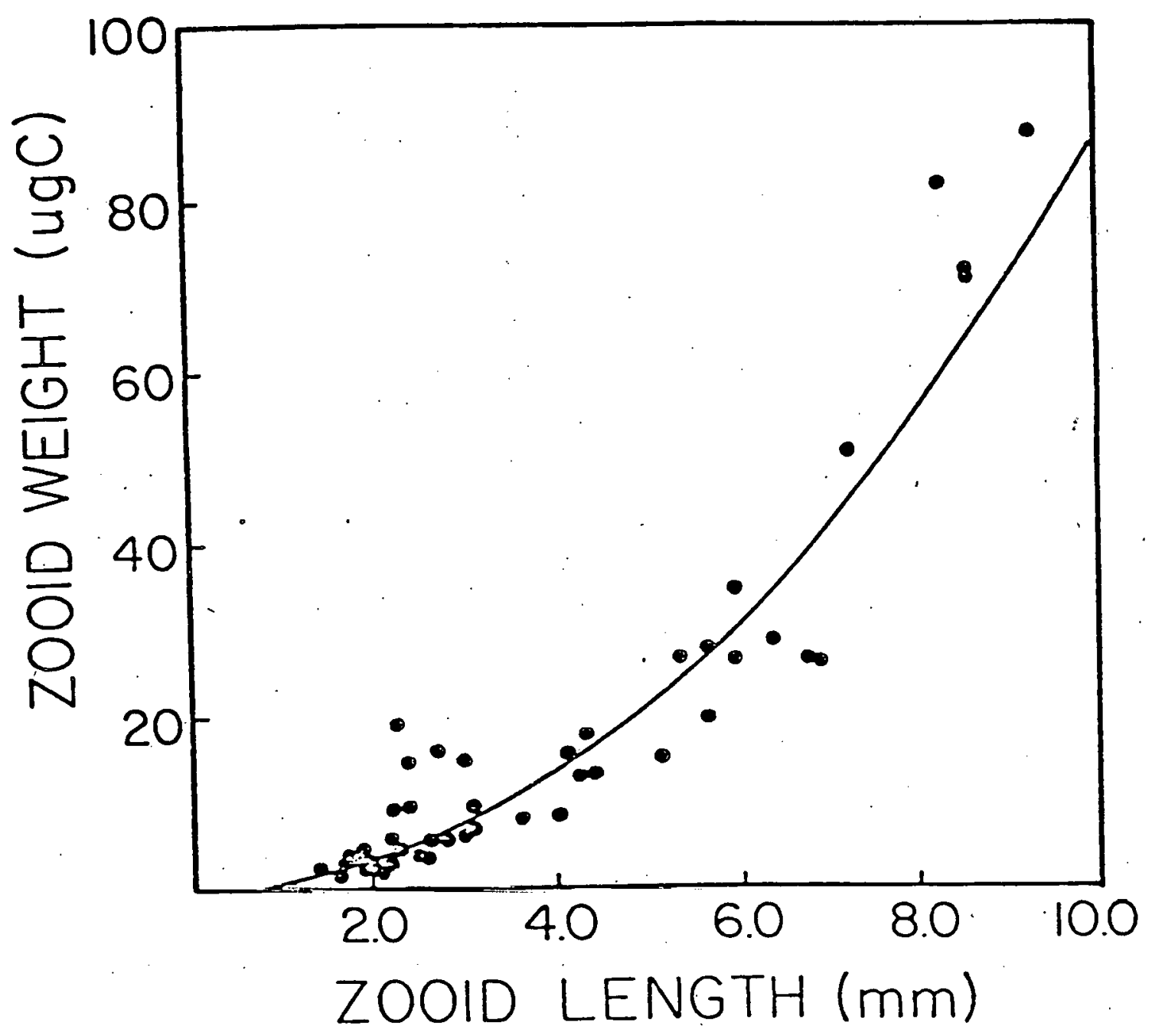




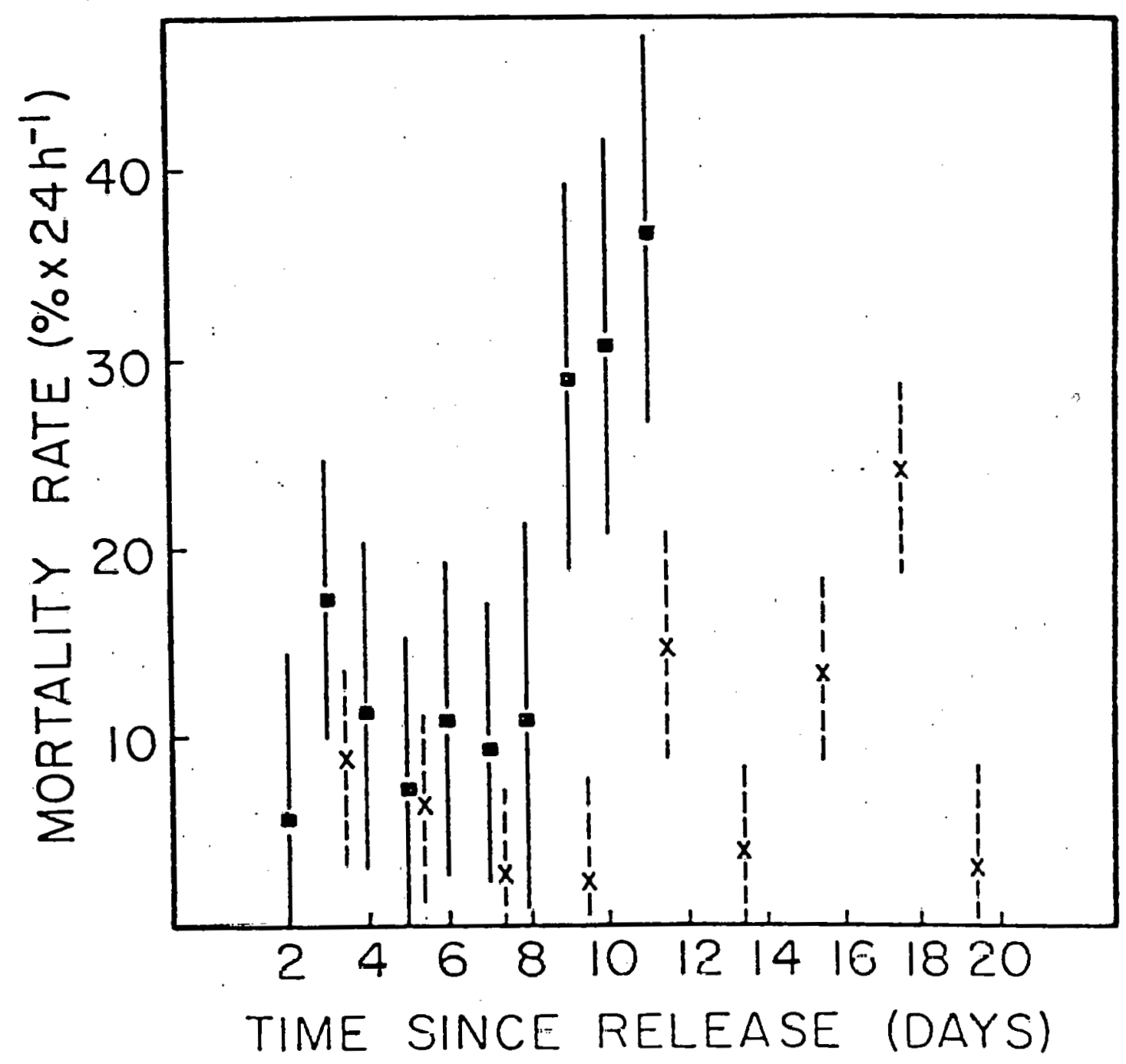




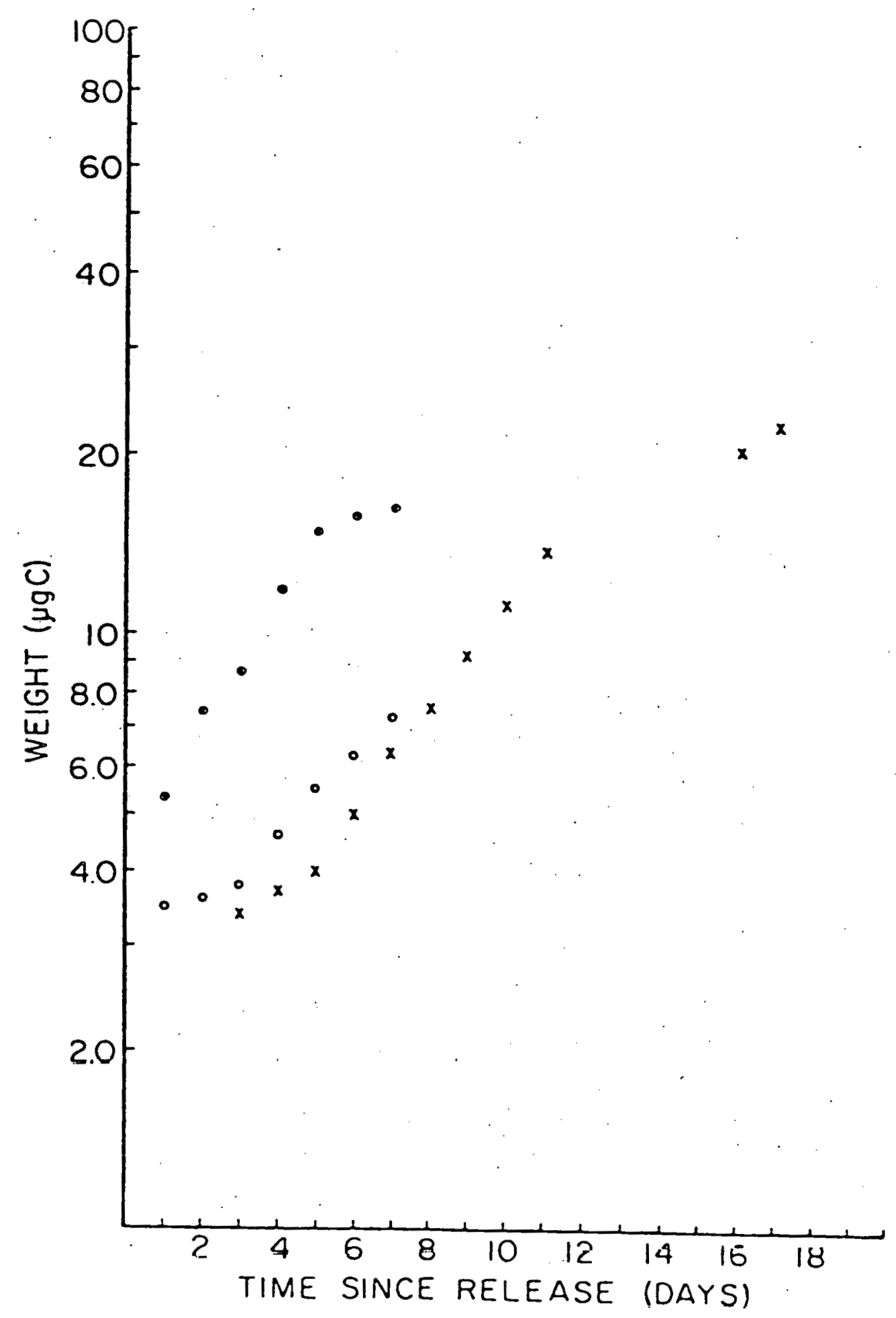




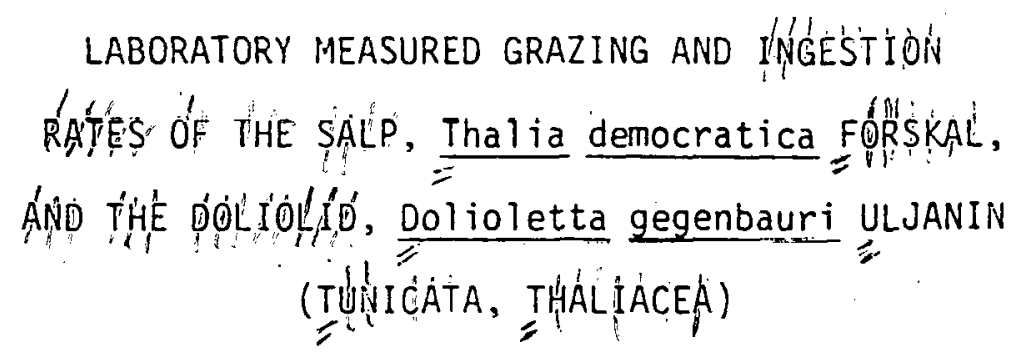

By

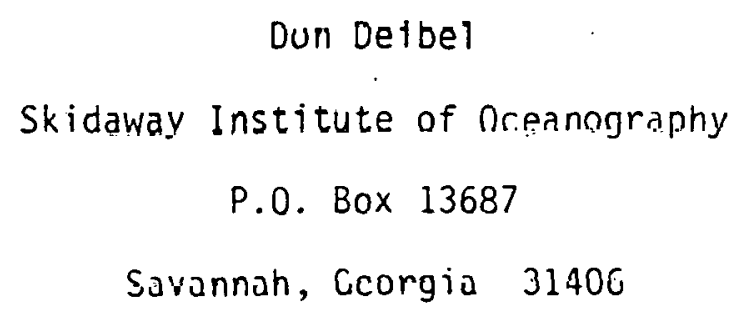

Rurning Head: Grazing and ingestion rates of Thalia and Dolioletta Journà of Plankion Research (suhnitted) 
ABSERACT

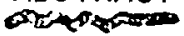

Grazing and ingestion rates of laboratory born Thalia democratica aggregates and Dolioletta gegenbauri gonozooids, phorozooids and oozcoids were determined while fed Isochrysis galbana (4-5 $\mu \mathrm{m}$ diameter) alone or 1. galbana and Peridinium trochoideum (16-18 $\mu \mathrm{m}$ diameter) in combination at concentrations of 0.15 to $0.70 \mathrm{~mm}^{3} \times 1^{-1}$. Grazing rates (mi $\times$ zooid $^{-1} \times 24 h^{-1}$ ) ranged from 10 to 355 and at zooid weights greater than $5 \mathrm{\mu g}$ carbon were in the order oozooid > gonozooid > aggregate. Grazing rates increased exponentially with increasing zooid weight. Weight-specific grazing rates ( $m \times \mu \mathrm{gC}^{-1} \times 24 \mathrm{~h}^{-1}$ ) were independent of the fourfold initial food concentration. Mean weightspecific grazing rates increased linearly with increasing zooid weight for the aggregates and oozooids but the gonozooid mean rates were independent of zooid weight. Aggregate and gonozooid ingestion rates 63 $-1$ $-1$ $(10 \mu \mathrm{m} \times$ zooid $\times 24 \mathrm{n})$ ranged from 4 to 134 while oozooid rates ranged from 3 to 67 . All ingestion rates were independent of the initial food concentration but increased linearly with increasing zooid weight at similar rates for all zooids. All mean weight-speciric ingestion rates $\left(\mathrm{ml} \times \mu \mathrm{gC} \times 24 \mathrm{~h}^{-1}\right)$ were independent of zooid weight. The mean aggregate daily ration ( $1 \mathrm{gC}$ ingested $\times \mu g$ body $C^{-1}$ ) was $59 \%$ and the mean doliolid ration was $132 \%$. Based on field and laboratory studies it is estimated that normal concontrations of ${ }_{3}$. gegenbauri in the Georgia Bignt clear their resident water :olume $(1 \mathrm{~m})$ in about 5 months but that highly concentrated, swarm populations which occur along thermohaline fronts clear their resident water volume in less than 1 day. 
INTRODUCTIOII

นn

In coastal waters off the southeastern United States the concen$-3$ tration of thaliaceans ranges from less than $20 \times \mathrm{m}^{-3}$ to over $3000 \times$ $-3$

$m$. Highest concentrations are associated with mid-shelf thermohaline fronts (Atkinson, et al., 1978; Deibel, 1980). The two dominant thaliaceans in the Georgia Bight are Thalia democratica and Dolioletta gegenbauri. These species range in length from 1.0 to $15 \mathrm{~mm}$, and in weight from about 2.0 to $300 \mathrm{\mu g}$ carbon. Salps graze sinall particles (< 1 um in dianeter) at high rates ( $\left.>11 \times \mathrm{h}^{-1}\right)$, using an efficient and continuously produced internal mucus net liladin, 1974; Harbison and Gilmer, 1976). Thougn Thalia and Dolioletta often dominate macrozooplankton biomass and numbers (Thompson, 1948; Braconnot, 1971a, b; Atkinson, et al., 1978) their role in the tropho-dynamics of neritic waters has been given limited attention. Knowledge of the grazing performance of the various life-history stages of $I$. denocratica and D. gegenbauri is essential to understand the transfer of materials in neritic plankton communities.

Small particle retention by oceanic salps has been studied (Silver, 1971; Braconnot, 1971b; Harbison and Gilmer, 1976; Harbison and McAlister, 1979) but there is little information on fooding by coastal specins. Oceanic salps retain small particles which adhere to the mucus feeding llel (Hadin, 19/4; Harbison and bilmer, 1976). The maximum size of ingestible particle is not known but presumably is constrained by mouth diameter (Silver, 1971; Deibel, unpublished). Although net-collected salps often do not feed in culture due to damage during collection or to collisions with vessel walls (Silver, 1971; 
Pavlova, et al., 1973) salp filtration rates have been found to range from 2 to $3001 \times 200 i^{-1} \times 24 \mathrm{~h}^{-1}$, increasing exponentially with increasing body length (Silver, 1971; Harbison and Gilmer, 1976). Filtration rates are not affected by changes in food concentration. Salps have higher weight-specific grazing rates $\left(m i \times \mu g C^{-1} \times 24 h^{-1}\right)$ than ascidians, ranging from 2 to 50 (Harbison and Gilmer, 1976): Salp weight-specific grazing rates increase with increasing body weight in contrast to the rates of ascidians which decrease. Neritic salps and doliolids feed at higher rates during the night than in the daytime and there is no particle selection in the range of 6 to $14 \mu \mathrm{m}$ diameter (Braconnot, 1971b). There may be fundanental differences in the feeding performances of salps and doliolids due to differences in mechanisms used to pump water. Salps contract circunferential muscle bands and swim continuously to feed and respire. Doliolids utilize stigmatal cilia to pump water and are usually notionless while feeding.

Comprehensive field and laboratory studies of neritic thaliacean feeding are essential to define the role of salps and doliolids in particle consumption in continental shelf ecosystems. The laboratory experiments reported were designed to answer the following questions:

(1) What are the range of grazing ( $m 1 \times 200 \mathrm{id}^{-1} \cdot \times 24 \mathrm{~h}^{-1}$ ) and $\begin{array}{llll}6 & 3 & -1 & -1\end{array}$ ingestion (10 un $\times$ zooid $\times 24 \mathrm{~h}^{-1}$ ) rates of the various life-history stages?

(2) llow do these rates change as the zooids grow?

(3) How do the weight-specifir grazing (m) $\times \mu \mathrm{gC}^{-1} \times 24 \mathrm{~h}^{-1}$ ) and $\begin{array}{llll}0 & 3 & -1 & -1\end{array}$ ingestion ( $10 \mu \mathrm{m} \times \mathrm{Hg} \mathrm{C} \times 24 \mathrm{~h})$ rates change as the zooids grow? Do changes indicate fundamental differences in salp and doliolid feeding performance due to known differences in feeding mechanisms? 
(4) How does weight-specifici ingestion (i.e., the daily ration) change as zooids grow?

(5) Given the known concentrations, life-history stages, and sizes of thaliaceans in the Georgia Bight (Deibel, 19S0) what is the grazing pressure ( $\mathrm{ml} \times$ population ${ }^{-1} \times 24 \mathrm{~h}^{-1}$ ) of naturally occurring salp and doliolid populations?

METHODS

Thaliaceans were collecten from outer continental shelf waters off the coast of Georgia, U.S.A. and were reared in the laboratory (Deibel, 1980). Grazing rates were determined while thaliaceans were fed Isochrysis galbana Parke (4.0-6.0 $\mathrm{\mu m}$ diameter) at 0.15 to $0.70 \mathrm{~mm}$ $-1$ $\times 1$ concentration. Grazing rates were also determined while thaliaceans were simultaneously fed $\underline{I}$. galbana and Peridinium trochoideum Lemmermann (16-18 $\mu$ mi diameter).

Feeding studies were conducted with zooids which were released in the laboratory from net-collected parents (Table 1). Feeding rates were monitored daily beginning 24 to $48 \mathrm{~h}$ after release. Measurements were terminated when mortality exceeded $15 \% \times 24 h^{-1}$, 8 to 15 days later. Grazing rates were estimated by the difference between particle cunrentrations at the beginning and end of a feeding incerval using a Coulter conunter monel TA II. Particles in the I. ydludlld chinnels were counted with coefficients of variation (precision) of 1 to $10 \%$. Feeding intervals ranged from 18 to $26 \mathrm{~h}$ and included day and night periods to integrate over possible diel grazing rate differences (braconnot, 1971b). At the end of each interval, thailaceans were transferred to a fresh food suspension and the next feeding interval was initiated. 
Increases in cell numbers in the phytoplankton suspensions were estimated from paired control bottles without thaliaceans. The presence of the tunicates was assumed not to alter phytoplankton growth over the short feeding intervals. Feeding over each interval reduced the total particle concentration 5 to $30 \%$ in doliolid experiments and 10 to $60 \%$ in experiments with salps (see Results).

Phytoplankton growth constants in the control bottles $(\mu \times 24$ $\begin{array}{llll}-1 & -1 & -1 & \end{array}$ $\mathrm{h})$, thaliacean grazing $(\mathrm{ml} \times$ zooid $\times 24 \mathrm{~h})$, and ingestion (10 $\mathrm{m}^{3} \times 24 \mathrm{~h}^{-1}$ ) rates were calculated using the equations of Frost (1972) and Harbison and Gilmer (1976). Growth constants were calculated for each Coulter Counter channel covering the size range of particulate food. Background counts were less than $5 \%$ of the particle numbers so no subtractions were made. Although algal growth constants were often an order of magnitude lower than thaliacean grazing rates they were routinely subtracted in calculating grazing rates. Zooids which died during a feeding interval were assumed not to have fed over that interval (Mullin and Brooks, 1970). Variability in grazing rates was without an apparent trend between contiguous channels covering the size ranges of $\underline{1}$. galbana and $\underline{P}$. trochoideum. Therefore a mean grazing rate was. calculated using rates from all channels containing at least $10 \%$ of the total particle volume. Accuracy of the Coulter Counter was monitored - frequently with inverted microscope counts of the food suspension. RESULTS

Although the Coulter Counter slightly underestimated true particle numbers, regression coefficients between cell concentrations determined with the counter (CC in particles $x \mathrm{mi}^{-1}$ ) and with the inverted 
microscope (Iii) were not significantly different from 1.0;

$$
C C=0.95(I M)-224(N=6, r=0.97, p>0.50) \text {. }
$$

Assuming that the inverted microscope reflects true particle numbers, this indicates that the coulter Counter yielded accurate estimates of particle concentration for I. galbana at concentrations up to 16,000 cells $\times \mathrm{mi}^{-1}$.

\section{Grazing Rates}

There was no significant difference between I. democratica aggregate mean grazing rates when fed $\underline{1}$. galbana or $\underline{p}$. trochoideum (Table 2); an observation which was supported by several single measurements from two other feeding experiments. Thus, grazing rates of both phytoplankters were pooled for further analyses. Due to the morphological similarity of gonozooids and phorozooids of $\underline{D}$. gegenbauri, and to the small number of phorozooids observed, all gonozooid and phorozooid data were combined. In the following discussion this group will be referred to as gonozooids. Aggregate grazing rates ranged froni 13 to 305 , ‥ gegenbauri gonozooid rates from 10 to 335 , and D. gegenbauri oozooid rates from 14 to $355 \mathrm{ml} \times 200 \mathrm{id}^{-1} \times 24 \mathrm{~h}^{-1}$ (Figure 1). The grazing rates of all three life-history stages are logarithmic functions of zooid weight. Since no oozooids of greater than $11 \mu g \mathrm{C}$ were observed in the feeding experiments, aggregate and gonozooid regression equations were recalculated using data froin the same weight range. These equations are not shown. Over the 0-11 $1 \mathrm{GC}$ weight range there is a significant difference $(p<0.001)$ between the aggregate regression coefficient (0.07, $n=20$ ) and the ouzooid coefficient $(0.14, n=18)$, but no diffo erence $(p>0.20)$ between the oozooid and gonozooid $(0.11, n=13)$ coefficients. however, gonozooid grazing rates were initially higher 
than those of oozooids $(p<0.001)$. Over the entire 0 to $20 \mu \mathrm{gC}$ weight range the gonozooid intercept is significantly greater ( $p$ : $0.01)$ than the aggregate intercept (1.16). This indicates that at weights greater than $5 \mu \mathrm{gC}$ grazing rates of the three life-histury stages are in the order oozooid > gonozooid > aggregate.

Grazing rates were corrected by calculating the weiglit-specific rates shown in figure 2. Height-specific grazing rates ranged from 1 to $13 \mathrm{ml} \times \mu \mathrm{gC}^{-1} \times 24 \mathrm{~h}^{-1}$ for aggregates, from 3 to 30 for the gonozooids and from 6 to 33 for the oozooids. Weight-specific rates were independent of the fourfold range in initial food concentration $(p>0.10)$.

I. democratica aggregates are released from the solitary stage in chains of 21 to 85 zooids (Deibel, 1980). Breaking these chains darnages individual zooids. Thus, complete chains were used in the feeding experinents often resulting in excessive decreases in food concentration over $24 \mathrm{~h}$ feeding intervals. Since decreased food concentration may alter grazing rates, the weight-specific grazing rates were screened for dependence on food concentration using regression analysis of variance (Figure 3 ). No dependence of aggregate and gonozooid weight-specific grazing on food concentration was apparent, but $28 \%$ of oozooid weight-specific grazing rate variability was related to decreases in food concentration. However, since the range of oozooid weight-specific grazing rate was only twofold between food concentration decreases of greater than or less than $30 \%$, all oozooid grazin.j rate data were used in subsequent analyses.

By pooling grazing rate estimates from contiguous $1 \mathrm{HgC}$ weight classes, mean weight-specific grazing rates can be calculated. size class mean aggregate and oozooid weight-specific rates depended 
on zooid weight but gonozooid rates were weight independent (Figure 4). Aggregate and oozooid size class mean rates increased with increasing zooid weight, ranging from 6 to $15 \mathrm{ml} \times \mathrm{\mu gc}^{-1} \times 24 \mathrm{~h}^{-1}$ for aggregates and from 10 to 33 for oozooids. The grand mean gonozooid weight-specific grazing rate, computed over all size classes, was $17.0 \pm 1.6( \pm S E)$.

Ingestion Rates

Aggregate ingestion rates ranged from 4 to $11210^{6} \mathrm{unl}^{3} \times 200 \mathrm{id}^{-1}$ $\times 24 \mathrm{~h}^{-1}$, gonozooid rates from 5 to 134 and oozooid rates from 3 to 67 (Figure 5). Ingestion rates of all three stages were independent of the initial food concentration but were dependent on zooid weight. Over the weight range of 0 to $11 \mu \mathrm{gC}$, the aggregate regression coefficient $(1.85)$ was significantly lower $(p<0.001)$ than the oozooid coefficient (6.64), but the oozooid and gonozooid equations were colinear $(p>0.10)$. Over the full $20 \mu \mathrm{gC}$ weight range (Figure 5 ), aggregate and gonozooid regression coefficients were not significantly different, but the gonozooid intercept was significantly greater $(p<0.01)$ than the aggregate intercept. At a given weight, aggregate ingestion rates were lower than gonozouid and oozooid rates and the ingestion rates of all life-history stages increased with increasing zooid weight at similar rates.

Doliolid and aggreficto mean weight-specific ingestion rates (Figure 6) were independent of zooid lieigiit. Aggregate weightspecific ingestion ranged from 1.7 to $6.010^{6} \mathrm{\mu m}^{3} \times \mathrm{\mu SC}^{-1} \times 24 \mathrm{~h}^{-1}$, and doliolid rates ranged from 4.0 to 8.0 . Since mean weightspecific ingestion rates were independent of zooid weight data from ali weight classes were pooled and grand means calculated. The 
aggregate grand mean $( \pm S E)$ weight-specific ingestion rate $(2.8 \pm 0.5$, $n=25)$ is significantly lower $(p<0.001)$ than the grand mean doliolid ingestion rate $(6.3 \pm 0.4, n=40)$.

\section{DISCUSSION}

\section{Grazing Rates}

Thaliacean grazing rates (Figure 1) are similar to those 0 ? large calanoid copepods (Paffenhöer, 1971; Corner, et al., 1972) but are lower than those of larger, oceanic salps (Harbison and Eilmer, 1976; Harbison and MCAlister, 1979). In my experiments, net-collected, adult aggregates decreased their grazing rates with time, indicating deleterious effects of capture or containment, which agrees with other studies of net-collected thaliaceans (Silver, 1971; Heron, 1972a; Harbison and Gilmer, 1976). However, I found that laboratory released zooids had linear increasing grazing rates over 7 to 14 days, indicating that they maintained vitality at a relatively constant level. The use of laboratory released zooids is an alternative method to hand collection for procuring undamaged zooids.

Thaliacean grazing rates depended on zooid weight, as is common among oceanic salps (Harbison and Gilmer, 1976), appendicularia (Paffenhöfer, 1976a) and copepods (Paffenhöfer and Harris, 1976). Aggregate Weight-specific grazing rates increased with increasing zooid weight (Figure 4), supporting abservations of the oceanic saip, Pegea confederata (Harbison and Gilmer, 1976). This contrasts with ascidians (Harbison and Gilmer, 1976) and calanoid copepods (Mullin and Brooks, 1970; Paffenhöfer, 1971) which decrease weight-specific grazing rate with increasing weight. Harhison and Gilmer (1976) hypothesized that 
muscular-driven water pumping and continuous swimming allow salps to filter exponentially increasing voumes of water as they grow. Unlike salps, doliolids and ascidians pump water by ciliary mechanisins. Gonozooids swim briefly to escape physical assault, e.g., contact with other zooplankton or rigid surfaces. Thus, one expects doliolids to resemble ascidians more than salps, i.e., doliolids should have decreasing weight-specific grazing rates with increasing zooid weight. This was not the case. Rather, oozooids increased weight-specific grazing rates with increasing weighl dnd yunusuvid rales were unrelated to increasing weight. These relations support the hypothesis of Harbison and Gilmer (1976) that planktonic tunicates may derive increased grazing efficiency as they grow by being able to move through the water. My notion that doliolids may be similar to the muco-ciliary feeding ascidians may be false since doliolids also move through the water, although aperiodically in conparison to salps.

Increasing grazing rates with a decrease in food concentration is common in appendicularia (Paffenhöfer, 1976a) and several copepods (Mullin, 1963; Anraku, 1964; Paffenhöfer, 1971, 1976b, c; Frost, 1972). Evidently; oceanic salps are unable to adjust grazing rates to changing food concentration (Silver, 1971; Harbison and Gilmer, 1976; Madin, 1974). In my study the grazing rates of all thaliaçeans were independent of food concentration changes (Figure 2). This evidence supports the unmodulated feeding behavior of salps which may explain the exciusion of most salps from particle rich coastal and estuarine waters (Harbison and Gilmer, 1976).

Although oceanic salps have greater weight-specific grazing rates than do ascidians (Harbison and Gilmer, 1976), the rates of salps, 
doliolids, appendicularians and copepods are similar (Table 3). There is only a 25 fold range in weight-specific grazing rate $(2-52 \mathrm{ml} \times$ $\mathrm{\mu gC}^{-1} \times$ individual ${ }^{-1}$ ) over a 900 fold range of zooplankton weight (2$1800 \mu g C \times$ individual $\left.^{-1}\right)$. Even though this similarity exists, a single, large, oceanic salp can have the grazing impact of ten to a hundred copepods due to its great weight (Harbison and Gilmer, 1976). Also, thaliaceans can have a pronounced impact on smail cells due to efficient small particle retention. Ingestion Rates

Ingestion rates were independent of the 4 fold range in initial food concentration indicating that grazing rates may be inversely related to food concentration. However, variability in grazing rates from separate replicate experiments nasks possible inverse relations between grazing rates and food concentration (Figure 2).

Thaliacean ingestion rates depended on zooid weight (Figure 5), as has been observed for other zooplankton (Mullin and Brooks, 1970; Paffenhöfer, 1971; Paffenhöfer and Harris, 1976; Paffenhöfer and Knowles, $1978 a, b)$. Since weight-specific ingestion rates are independent of zooid weight (Figure 6) as weight increases, the daily ration ( $1 \mathrm{gC}$ ingested $\mathrm{x} \mu \mathrm{g}$ body $\mathrm{C}^{-1}$ ) must remain constant. Such observations also have been inade of two copepod species (Paffenhöfer and Harris, 1976; Harris and Paffenhöfer, 1976).

Using the niean weight-specific ingestion rates for aggregates and doliolids (Figure 6), and the following equation to convert the food volume of Isochrysis galbana lo carbon, one can compute the rean daily ration.

$$
\left.C(\mu g)=211\left(v, m^{3}\right)^{3}\right)-1.31 \quad(n=13, r=0.99)
$$


The aggregate mean daily ration was $59 \%$, and the doliolid mean daily ration was $132 \%$. There are no comparable ration data for any thaliacean although these values are similar to those of appendicularia (Paffentöfer, 1976a) and copepods (Paffenhöfer, 1971; 1976b; Paffenhöfer and Knowles, 1978a,b; Paffenhöfer and Harris, 1976) determined at similar food concentrations. Although the difference between the aggregate and doliolid daily rations may represent true biological differences between these species in feeding mechanisil, a degree. of uncertainty is introduced into the computation of the doliolid ration because of the necessity of estimating doliolid weight from the aggregate length-weight regression (Deibel, 1980).

To estinate the population grazing rate of Dolioletta the following calculations were made. In non-swarm conditions there are approximately 25 zooids $\times \mathrm{m}^{-3}$ with a known life-history stage and size=class compusition (Defbel, 1980). Since grazing rates were not determined for the largest zooid size classes in the field populations, a median weight-specific grazing rate of $20 \mathrm{ml} \times \mu \mathrm{C}^{-1} \times 24 \mathrm{~h}^{-1}$ was chosen (Figure 4) as the best estimate for all size classes. Some inaccuracy results but this is sufficient for a first estimate. The median grazing rate was multiplied by the biomass in each size class ard then the individual size class grazing rates were sumned over all classes to arrive at a population grazing rate estinat.r. These 25 zooids $\times \mathrm{m}^{-3}$ sweep clear $81 \times 24 \mathrm{~h}^{-1}$, or their resident water volunie (i.e., $1 \mathrm{~m}^{3}$ ) each 125 days. In doliolid "swarms" gonozooids often number more than $3000 \times \mathrm{m}^{-3}$. This swarm population sweeps clear 1142 $1 \times 24 \mathrm{~h}^{-1}$, or its resident viater volume every $21 \mathrm{~h}$. Since swarms inay persist for days and possibly for weeks (Deibel, 1980) phytoplankton 
must double their number each day simply to maintain the food supply for the doliolid population. This production can only occur through phytoplankton reproduction or by the advection of phytoplankton and non-living particulate matter into the swarm area from a surrounding zone of higher particle concentration.

In sumnary, (1) net-collected zooids could not be used for feeding studies because of decreasing grazing rates with time. Instead, laboratory released offspring were successfully maintained and studied for weeks; (2) grazing rates increased exponentially with increasing zooid weight, wille ingestion rates increased linearly with increasing zooid weight. Rates compared to those reported for large calanoid copepods but were less than those of larger oceanic salps; (3) weightspecific grazing rates were a linear function of increasing zooid weight for 00zooids and aggregates, but were constant for gonozooids. Weight-specific rates are similar to those of a wide range of copepods and tunicates; (4) daity rations, in terms of carbon, were independent of increasing zooid weight and were lower for Thalia than for Dolioletta:

(5) non-swarm concentrations of doliolids clear their resident water volume in about 5 months, but during swarms they clear their resident water volune in less than $24 \mathrm{~h}$.

ACKNOWLEDGEMENTS

This manuscript was adapted from a dissertation submitted in partial fulfillment of the requirements for the Ph.D. degree, Department of Zoology, University of Georgia, Athens. It was. improved by the comments of Drs. D.W. Menzel and G.-A. Paffenhöfer. Drafting of the figures was by ilr. 'D. Picintosh. The work was supported by Department 
of Energy contract DE-AS 09-76EV00936 to Dr. G.-A.P., to whom the author is grateful for inspiration and guidance. 


\section{REFERENCES}

Anraku, M.: 1964, 'Influence of the Cape Cod Canal on the hydrography and on the copepods in Buzzards Bay and Cape Cod Bay, Massachusetts. II. Respiration and feeding.' Limnol. Oceanogr.9(2), 195-206. ntkinson, L.P., Paffenhöfer, G.-A., and Dunstan, W.M.: 1978, 'The chemical and biological effects of a Guif Stream intrusion off St. Augustine, Florida.' Bull. Mar. Sci. 28(4), 667-679. Braconnot, J.-C.: 1971a, 'Contribution à l'étude biologique et ecologique des Tuniciers pélagiques Salpides et Doliolides I. Hydrologie et ecologie des Salpides.' Vie Millieu. 22(2, Ser. B), $257-286$.

Braconnot, J.-C.: 1971b, 'Contribution à l'étude biologique et ecologique des Tuniciers pélagiques Salpides et Doliolides II. Ecologie des Doliolides, biologie des deux groupes.' Vie Millieu. $22(3$, Ser. B. $), 437-467$.

Corner, E.D.S., Head, R.N., and Kilvington, C.C.: 1972, 'On the nutrition and metabolism of zooplankton VIII. The grazing of Biddulphia cells by Calanus helgolandicus.' J. Mar. Biol. Ass. U.K. 52, 847-861.

Deibel, D.: 1980, 'Feeding, growth and swarm dynamics of neritic tunicates from the Georgia Bight.' Ph.D. Thesis, Univ. of Georgia, Athens, $156 p$.

Frost, B.W.: 1972, 'Effects of size and concentration of food particles on the feeding behavior of the marine planktonic copepod Calanus pacificus.' Limnol. Oceanogr. $17(6), 805-815$.

Harbison, G.R., and Gilmer, R.W.: 1976, 'The feeding rates of the 
pelagic tunicate Pegea confederata and two other salps.' Limnol. Oceanogr. 21, 517-528.

Harbison, G.R., and McAlister, V.L.: 1979, 'The filter-feeding rates and particle retention efficiencies of three species of Cyclosalpa (Tunicata, Thaliacea).' Limnol. Oceanogr. 24(5), 875-892.

Harris, R.P., and Paffenhöfer, G.-A.: 1976, 'Feeding, growth and reproduction of the marine planktonic copepod Temora lorigicornis Miiller.' J. mar. biol. Ass. U.K. 56, 675-690.

Heron, A.C.: 1972, 'Population ecology of a colonicing species: The pelagic tunicate Thalia democratica I. Individual growth rates and generation time.' Decologia (Berl.). 10, 269-293.

Madin, L.P.: 1974. 'Field observations on the feeding behavior of salps (Tunicata: Thaliacea).' Mar. Biol. 25, 143-147.

Mullin, M.M.: 1963, 'Some factors affecting the feeding of marine copcpods of the genus Calanus.' Limnol. Oceanogr. $8(3), 239-250$. Mullin, M.M., and Brooks, E.R.: 1970, 'The effect of concentration of food on body weighi, cumulative ingestion, and rate of growth of the marine copepoil Calanus helgolandicus.' Limnol. Ocear:ugr. 15, 748-755.

Paffenhöfer, G,-A.: 1971, 'Grazing and ingestion rates of nauplii, copepodids, and adults of t!le marine planktonic copepod calanus helgolandicus.' Mar. Biol. 11(3), 286-298.

Paffenhöfer, G.-f..: 1976a, 'Un the biology of appendicularia of the Southeasterr: North Sea.' European Marine Biology Symposiuin, luth. Ostend, Eelgium, 1975. 237-455.

Paffenhöfer, G.-A.: 1976b, 'P.cint nuous and nocturnal jeeding of the marine planktonic copepod Calanus helgolandicus.' Bull. Mar. Sci: 
$26(1), 49-58$.

Paffenhöfer, G.-A.: 1976c, 'Feeding, growth, and food conversion of the marine planktonic copepod Calanus helgolandicus.' Limnol. Oceanogr. $21(1), 39-50$.

Paffenhöfer, G.-A., and Harris, R.P.: 1976, 'Feeding, grow'th and reproduction of the marine planktoric copepod Pseudocalanus elongatus Boeck.' J. mar. biol. Ass. U.K. 56, 327-344.

Paffenhöfer, G.-A., and Knowles, S.C.: 1978a, 'Laboratory experiments on feeding, growth, and fecundity of and effects of cadmium on Pseudodiaptonus.' Bul1. Mar. Sci. 28(3), 574-580.

Paffenhöfer, G.-A., and Knowles, S.C.: 1978b, 'Feeding of marine planktonic copepods on mixed phytoplankton.' Mar. Biol.48, 143-152.

Pavlova, E.V., Petipa, T.S., and Sorokin, Y.I.: 1973, 'Bacterioplankton as food for pelagic marine organisms.' Pages 156-165 in Life activity of pelagic conmunities in the ocean tropics, M.E. Vivogradov, ed. Israel Program for Sci. Transl., Jerusalem. Silver, M.E.: 1971, 'The habitat of Salpa fusiformis in the California Current as defined by stomach content studies and the effect of salp swarms on the food supply of the plankton community.' Ph.D. Thesis. Univ. Calif., San Diego. 135p.

Thompson, H.: 1948, 'Pelagic tunicates of Australia.' Comm. Council. Sci. Industr. Res. Melbourne, 196p. 
TABLES

$14-19$

,

.

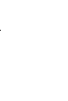

\section{TABLES

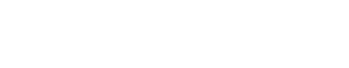

.


lable 1. A sulisidy of the conditions of inc laboratory experiments. All dato are the oriemiati:

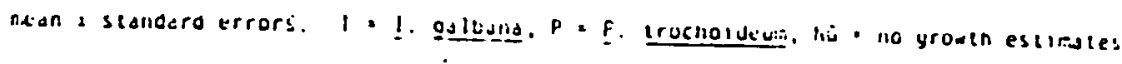
eere nude.

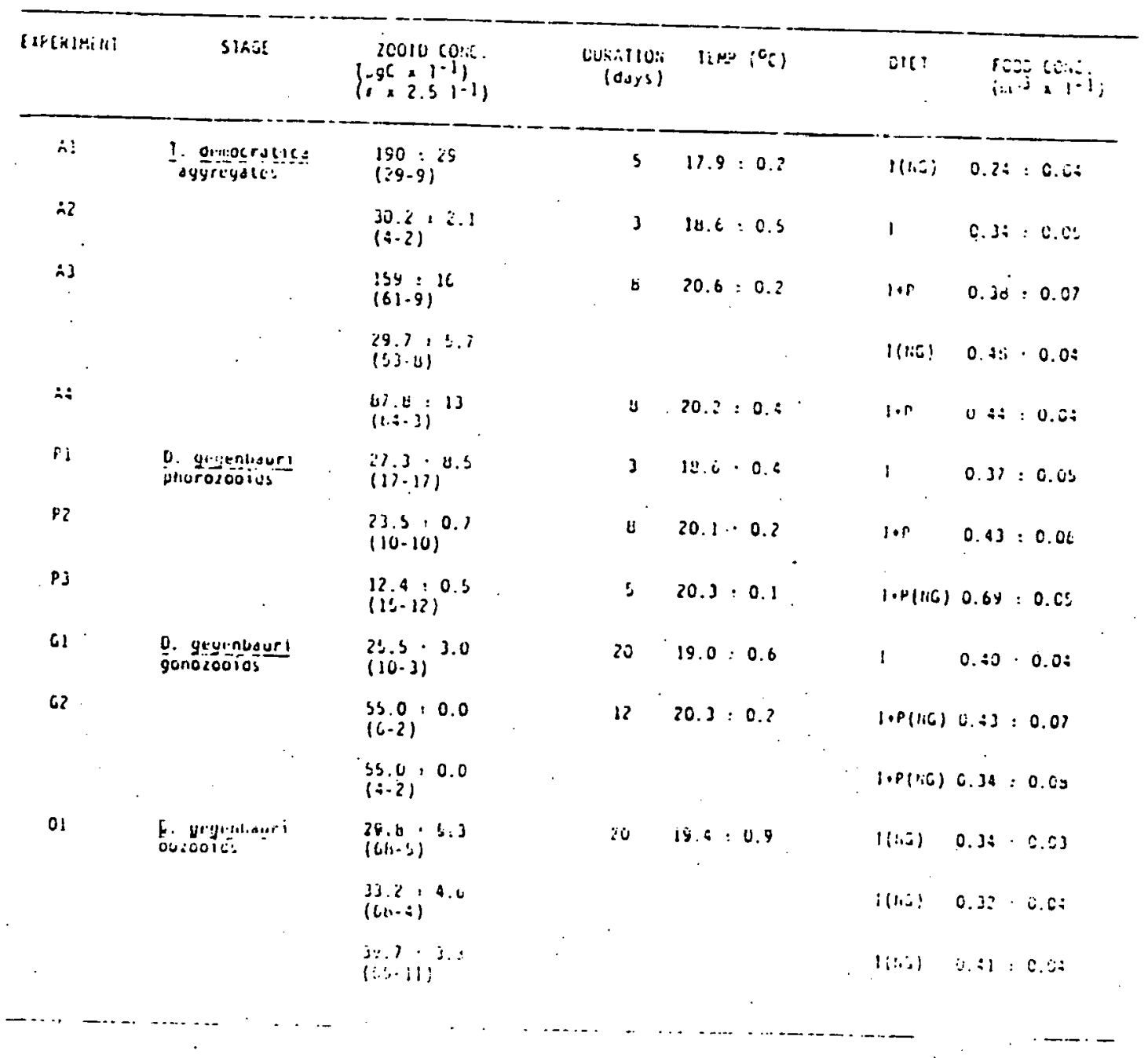


Table II. Mean grazing rates $\left(\mathrm{ml} \times 200 \mathrm{id}^{-1} \times 24 \mathrm{~h}^{-1}\right)$ of $\underline{I}$.

galbana and $\underline{P}$. trochuideum by $\underline{I}$. democratica aggregates. NS - ditference not signtficant at the $95:$ ronfidence levcl.

The means were compared by one-way ANOVA. SE = standard error of the mean.

\begin{tabular}{llll}
\hline GOOD & $\begin{array}{c}\text { GRAZING RATE } \\
(\bar{X} \pm \text { SE })\end{array}$ & $n$ & $F_{1,11}$ \\
\hline$\underline{\text { I. galband }}$ & $38.4 \pm 5.3$ & 7 & 0.36 (NS) \\
$\underline{P}$. trochoideum & $33.8 \pm 5.7$ & 6 & \\
\hline
\end{tabular}


Table III. Weight-specific grazing rates of assorted marine zooplankton. Food concentrations were between 20 and $200 \mu \mathrm{gC} \times 1^{-1}$ for all studies except Harbison and Gilmer (1976), which was from 200 to 1400 ugC $\times 1^{-1} . \quad A G=$ aggragate stage, SOL = soiitary, $G Z=$ gonozooid, and $0 Z=00 z 00 i d$.

\begin{tabular}{|c|c|c|c|c|c|c|}
\hline Organism & Stage & $\begin{array}{l}\text { Temp. } \\
\left({ }^{\circ} \mathrm{C}\right)\end{array}$ & $\begin{array}{l}\text { Length } \\
(\mathrm{mm})\end{array}$ & $\begin{array}{l}\text { Weight } \\
(\mu g C)\end{array}$ & $\begin{array}{l}\text { Weight-Specific } \\
\text { Grazing Rate } \\
\text { (m) } \times \mu \operatorname{aC}^{-1} \times 24 \mathrm{~h}^{-1}\end{array}$ & Source \\
\hline C. helgolandicus & - & 15 & - & $\begin{array}{l}10 \\
80\end{array}$ & $\begin{array}{l}19 \\
10\end{array}$ & Paffenhöfer, 1971 \\
\hline P. elongatus & - & 12.5 & - & 4.0 & $\begin{array}{l}8.0 \\
52\end{array}$ & Paffenhöfer and Harris, 1976 \\
\hline I. longicornis & - & 12.5 & - & 4.0 & $\begin{array}{l}11 \\
32\end{array}$ & Harris and Paffenhöfer, 1976 \\
\hline 0. dioica. & - & 13 & - & $\begin{array}{l}4.0 \\
8.0\end{array}$ & $\begin{array}{l}27 \\
38 \\
32 \\
44\end{array}$ & Paffenhöfer, $1976 a$ \\
\hline P. confederata & $\begin{array}{l}\text { AG } \\
\text { SOL }\end{array}$ & $25-29$ & $\begin{array}{l}15 \\
50 \\
15 \\
50\end{array}$ & $\begin{array}{r}106 \\
1416 \\
242 \\
1821\end{array}$ & $\begin{array}{l}2.0 \\
38 \\
4.0 \\
8.0\end{array}$ & Harbison and Gilmer, 1976 \\
\hline I. democratica & $A G$ & 20 & $\begin{array}{l}2.7 \\
3.3 \\
4.2\end{array}$ & $\begin{array}{l}6.4 \\
9.8 \\
16\end{array}$ & $\begin{array}{l}7.0 \\
9.0 \\
12\end{array}$ & This study \\
\hline \multirow[t]{2}{*}{ - ‥ gegenbauri } & $\mathrm{GZ}$ & 20 & $1.7-4.9$ & $2.4-23$ & $17 \pm 1.6(\bar{X} \pm S E)$ & \\
\hline & $0 Z$ & 20 & $\begin{array}{l}1.4 \\
2.5 \\
3.4\end{array}$ & $\begin{array}{r}1.5 \\
5.5 \\
10.5\end{array}$ & $\begin{array}{l}8.0 \\
17 \\
28\end{array}$ & \\
\hline
\end{tabular}




\section{FIGUPE LEGENDS}

Figure 1. Grazing rate versus weight for $T$. democratica aggregates and $\underline{0}$. gegenbauri gonozooids and oozooids. All points are means \pm standard error. Grazing rates were calculated only for those days with mortality rates of less than $15 \%$. The regression equations are: Aggregates $(\bullet-\bullet), \log _{10} G R=0.07 W+1.16\left(n=25, R^{2}=85 \%, p<0.001\right)$. Conozooids $(--\infty), \log _{10} G R=0.06 W+1.50\left(n=23, R^{2}=58 \%, p<0.001\right)$. 0ozooids $(x--x), \log _{10} G R=0.14 W+1.07\left(n=18, R^{2}=88 \%, p<0.001\right)$. Figure 2. Weight-specific grazing rate versus the initial food concentration for I. democratica aggregates $(\bullet)$, D..gegenbauri gonozooids $(0)$, and oozooids $(x)$. Rates are independent of the initial food concentration $(p>0.10)$.

Figure 3 . Weight-specific grazing rate versus the $\%$ food concentration decrease for $\underline{T}$. democratica aggregates $(\bullet)$, D. gegenbauri gonozooids $(0)$, and oozooids $(x)$. The $\%$ food concentration decrease $=\{($ initia $\}$ food concentration - final food concentration) $\div$ ( initial food concentration) $\}$ $x$ 100\%. The aggregate and gonozooid rates are independent of the food concentration decrease $(p>0.05)$ but $R^{2}$ for the oozonids $=28 \%$, and the regression coefficient is significantly different from zero $(p<0.05)$. Figure 4. Mean (t standard error) weight-specific grazing rates versus zooid weight. From 2 to 5 values were pooled for the calculation of each mean. Points without error bars were single observations for that. weight class. The regression equations are: Aggregates $(0-\bullet)$ WSGR $=0.42 \mathrm{~W}+5.16 \quad\left(n=12, R^{2}=59 \%, p<0.01\right)$. Gozooids $(x--x)$ WSGR $=2.22 W+5.07 \quad\left(n=8, R^{2}=81 \%, p<0.01\right)$. The gonozooid ( $)$ mean rates are independent of zooid veight $(p>0.10$ ). The grand mean for this group is $17.0 \pm 1.6 \mathrm{ml} \times \mu \mathrm{gC}^{-1} \times 24 \mathrm{~h}^{-1}(n=23)$. 
Figure 5. Ingestion rate versus zooid weight for I. democratica aggregates $(0-0)$, and $\underline{D}$. gegenbauri gonozooids $(\mathbf{x - - \infty )}$, and oozooids $(x--x)$.

The regression equations are:

Aggregates $I R=4.43 W-10.4 \quad\left(n=25, R^{2}=76 \%, p<0.001\right)$.

Gonozooids $I R=4.51 \mathrm{~W}+1.4 .5 \quad\left(n=22, R^{2}=41 \%, p<0.01\right)$.

0ozooids $I R=6.64 \mathrm{~W}-3.18 \quad\left(n=18, R^{2}=85 \%, p<0.001\right)$.

Figure 6. Mean ( \pm standard error) weight-specific ingestion rate versus zooid weight. $(0)=$ T. democratica aggregates, and $(x)=$ all $\underline{D}$.

gegenbauri zooids. All rates are independent of zooid weight $(p>0.05)$.

The grand mean ( \pm standard error) for the aggregates is $2.8 \pm 0.5$

$(n=25)$, and for the doliolids it is $6.3 \pm 0.410^{6} \mu^{3} \times \mu g C^{-1} \times 24 \mathrm{~h}^{-1}$

$(n=40)$. 

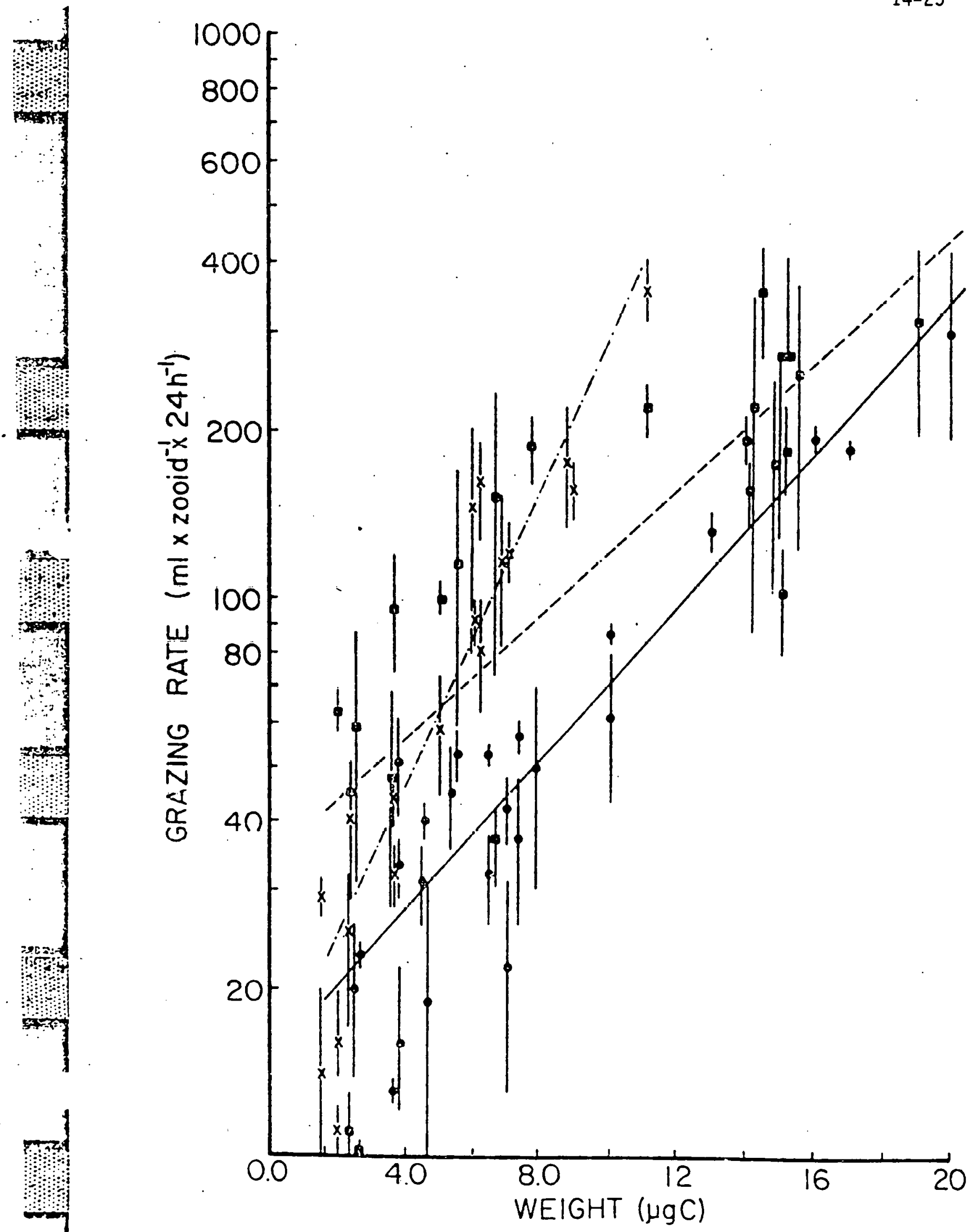


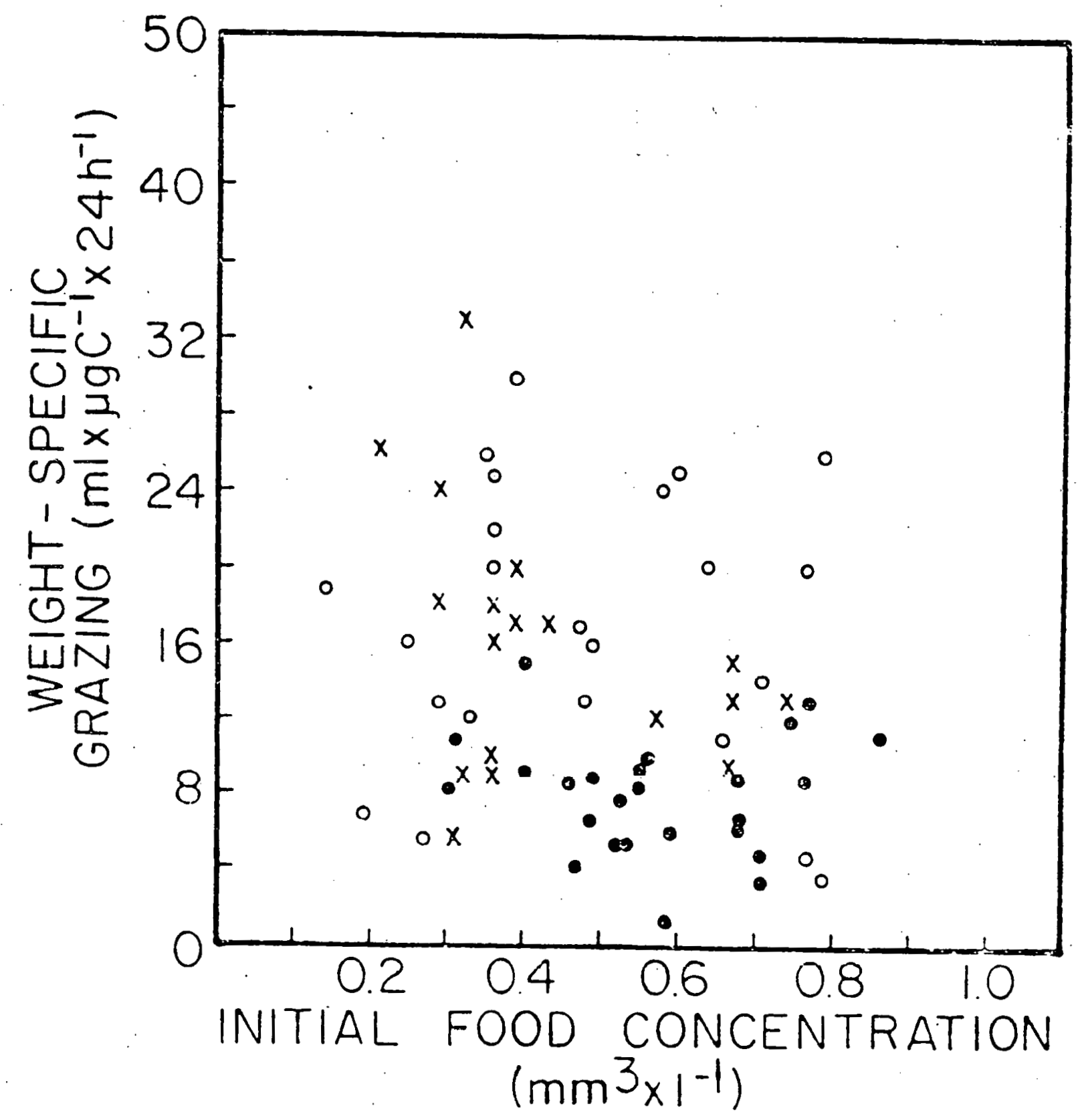




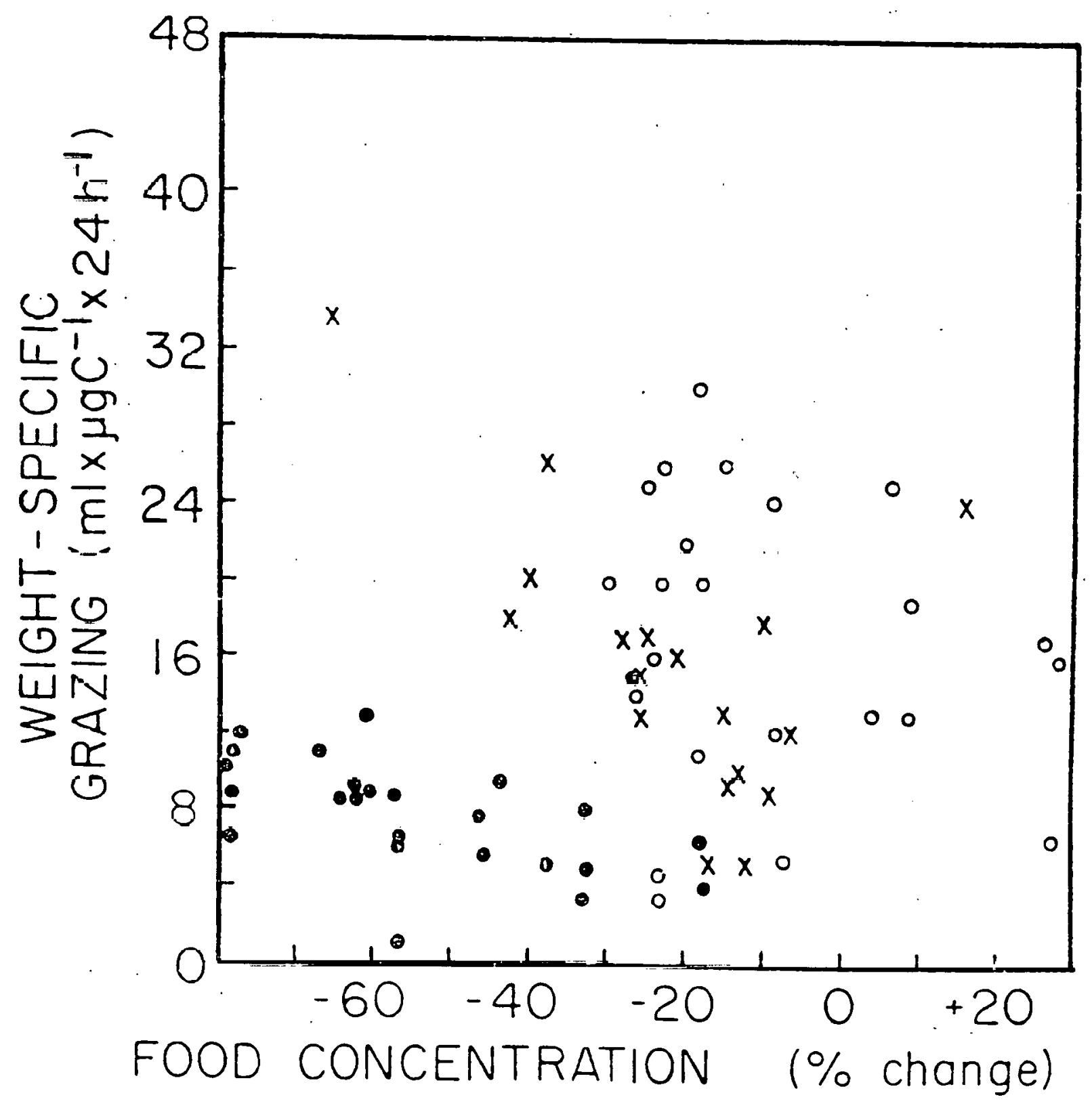




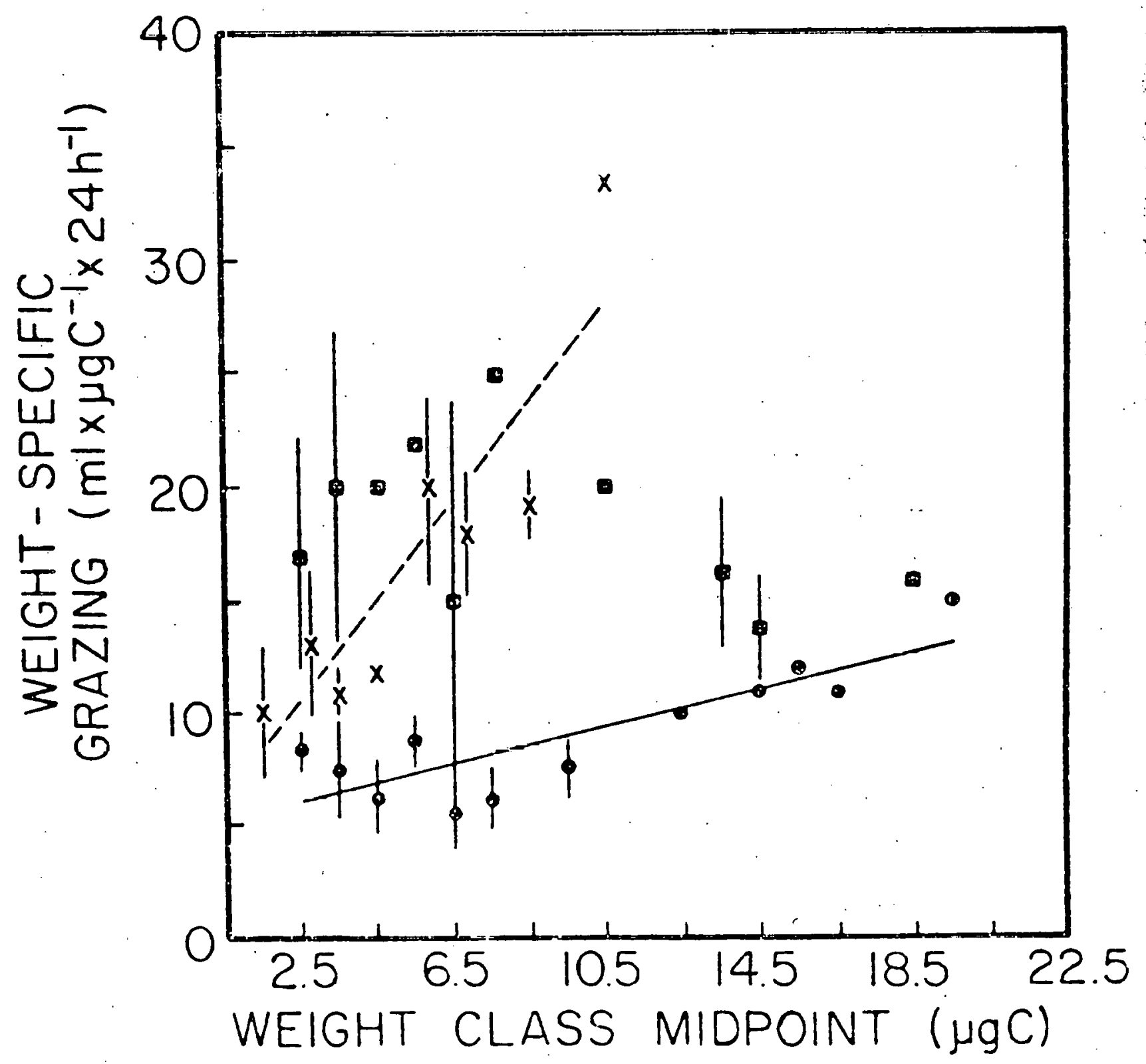


$\frac{E}{2}$

L. $\checkmark$

a
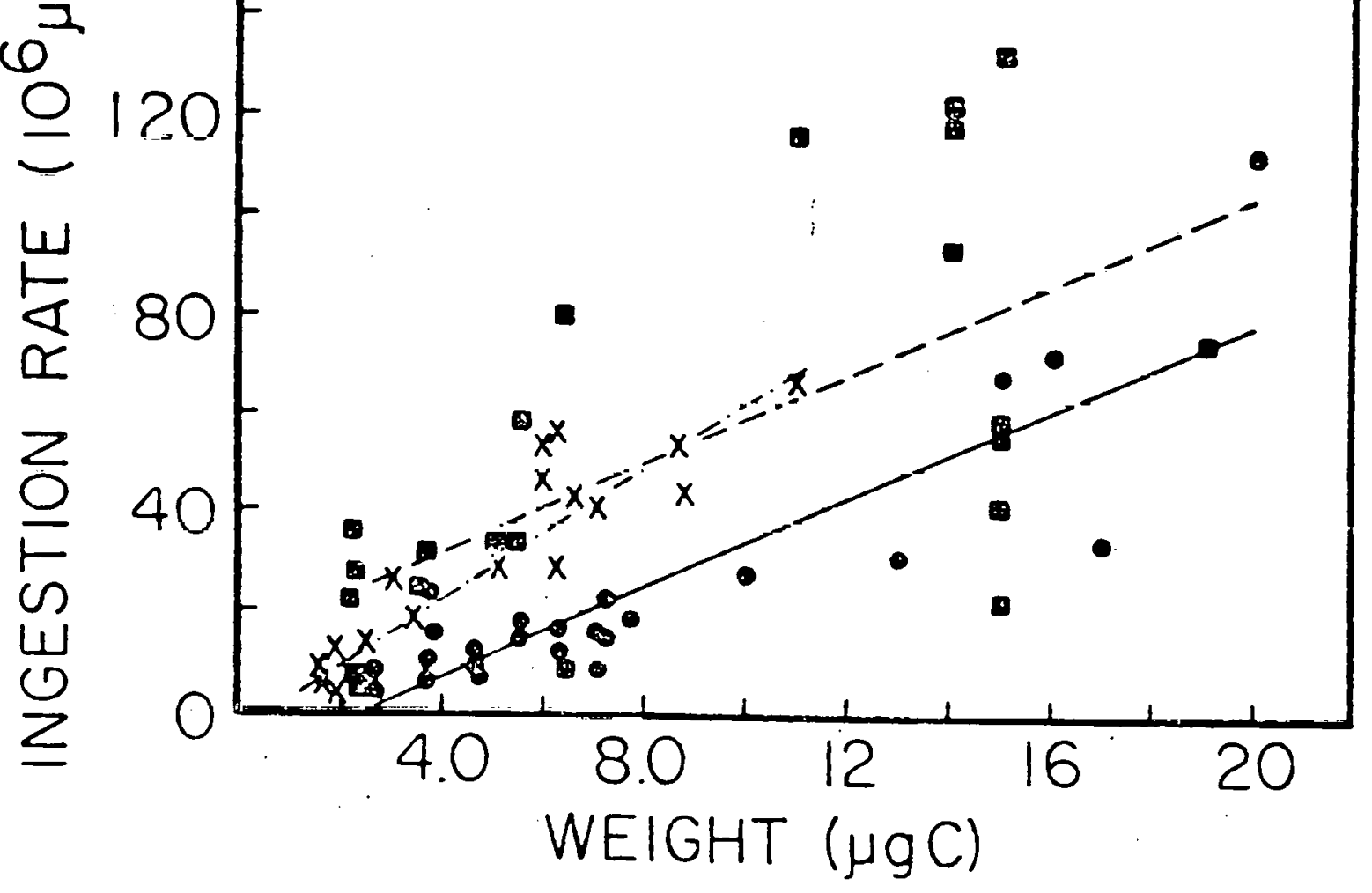


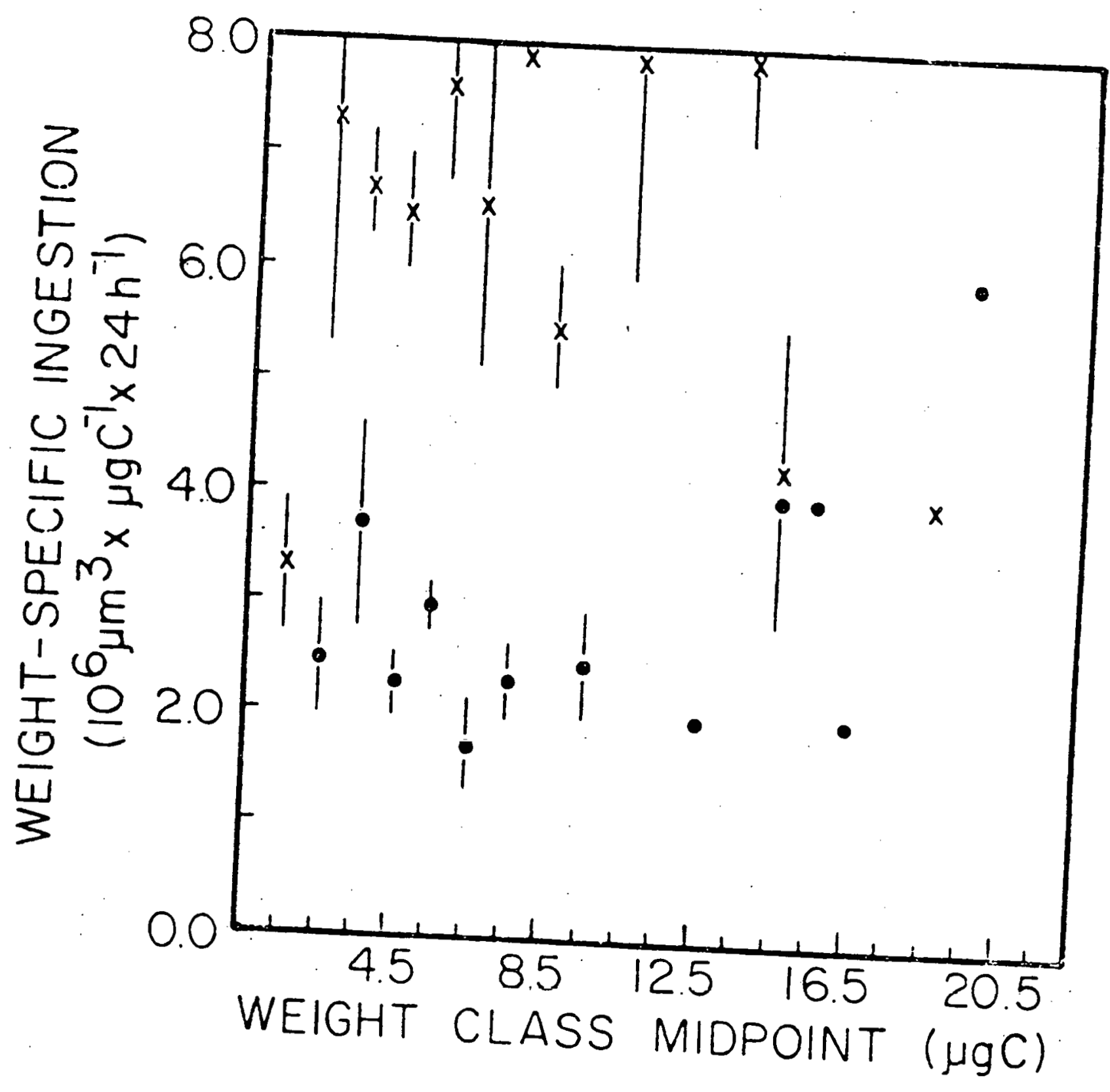


NITROGEN REGENERATION BY THE SUBTROPICAL MARINE COPEPOD EUCALANUS PILEATUS ${ }^{-1}$

by

\author{
Wayne S. Gardner ${ }^{2}$ \\ and
}

Gustav A. Paffenhöfer ${ }^{3}$

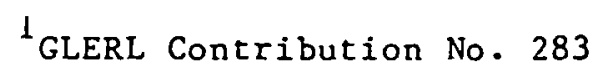
${ }^{2}$ Natinnal Oceanis and Atmoopherir Aiministialiuu Great Lakes Environmental Research Laboratory 2300 Washtenaw Avenue Ann Áror, Michigan 48104
${ }^{3}$ Skidaway Institute of Oceanography P.0. Box 13687
Savannah, Georgia 31406

Submitted to Journal of Plankton Research 
Nitrogen Regeneration by the Subtropical Marine Copepod Eucalanus pileatus

by

Wayne S. Gardner and Gustav A. Paffenhöfer

ABSTRACT

Ammonium release rates by Individual marine copepods (Eucalanus pileatus) were examined kinetically over successive 10-min intervals after exposing the animals to three concentrations of the diatom Thalassiosira fluviatilis as food. Food concentrations spanned those expected in the natural environment. "Well-fed" (3 $\mathrm{mm}^{3} \mathrm{I}$. fluviatilis liter $\left.{ }^{-1}\right)$ copepods released ammonium significantly $(p<0.05)$ faster than those fed zero or low concentrations of food, but differences were not dramatic. Mean excretion rates ( \pm SE) for animals removed from food for 18-22 h [30 \pm 6 nmoles $\mathrm{NH}_{4}$ (mg ash free dry weight) ${ }^{-1} h^{-1}$ ] were about $60 \%$ of those for "well-fed" animals [49 \pm 8 imoles $\mathrm{NH}_{4}$ (mg ash free dry welght) ${ }^{-1} \mathrm{~h}^{-1}$ ). Depending on food concentration, animals released ammonium at rates ranging from 40 to greater than $100 \%$ of their $N$ ingestion rates over the previous 18-22 h. Long-term ( 4 to 6h) kinetic excretion experiments with "well-fed" anlmals indicated that, on the average, release rates decreased with time after food removal, but patterns varled among individual copepods. In addition to amonium release, ophthalaldehyde reactive amino acld nitrogen was occasslonally released by $\underline{E}$. pileatus in large "spurt everts" lasting from 20 to 60 min. 


\section{INTRODUCTION}

Nitrogen in food ingested by copepods is incorporated for growth and reproduction, released in soluble form, egested in fecal pellets, or lost as molted exoskeletal or other materials. The percentage of ingested nitrogen incorporated into body tissue of copepods can range from a negative value (loss) to 49.2 depending on the ration (Corner et al. 1976). Thus, considerable amounts (often more than 50\%) of ingested nitrogen are relcoscd by the feeders. Several studies have indicated that increases in food levels are accompanied by increases in dissolved nitrogen release rates (Corner et al. 1972; Takahash1 and Ikeda 1975; Corner et al. 1976; Nelson et al. 1979). Although organic compounds such as urea (Corner and Newell 1967; Eppley et a1. 1973; Corner et al. 1976; Smith 1978) and amino acids (Johannes and Webb 1965; Webb and Johannes 1967; Kremer 1977) account for a portion of nitrogen released by marine invertebrates, ammonium is thought to be the primary form of dissolved nitrogen released by zooplankters (Corner et a1. 1972; Corner et al. 1976; Gardner and Miller 1981). Release of amonium by copepods is relevant to marine ecosystem dynamics both because it is the preferred form of nitrogen for phytoplankton uptake and because regenerated nitrogen is essential to maintaining phytoplankton production in regions of nitrogen limitation (McCarthy and Goldman 1979). Except for studies involving special precautions (Peters and Rigler 1973; Takahashi and Ikera 1975; Lehman 1980; Gardner and Scavia 1981), previous zooplankton excretion experiments have tended to underestimate natural rates of nutrient release, efther because nutrients were taken up by phytoplankton during incubation or because partially starved animals were used (Takahashi and I,keda 1975). 
In this study, we hypotheslzed that ammonium excretion by feeding copepods may account for a large portion of ingested nitrogen and that excretion rates may be directly related to food supply. To consider the effects of food on the magnitude and kinetics of nitrogen regeneration, we measured ammonium release rates for the subtropical marine copepod Eucalanus pileatus as a function of food concentration, ingestion rate, and time after food removal. Individuals were used to provide information on time-related patterns as well as magnitude of ammonium release. Amino acid release patterns were observed, but not quantified, for several hours after food removal on animals fed relatively high levels of food.

METHODS

The Eucalanus pileatus ( 1 copepodid Stage $V$ and 28 adult females) used for this study were elther collected from the Atlantic Ocean in coastal waters offshore from Savannah, Ga., or reared from eggs in the laboratory (Paffenhöfer and knowles 1978). They were maintalned at $20^{\circ} \mathrm{C}$ on a diet of 1.0 to $1.5 \mathrm{~m}^{3}$ Thalassiostra fluviat1lis 1 iter ${ }^{-1}$ for 1 to 2 weeks before experiments. The animals vere contained in sea water in a closed botte attached to a rotating wheel ( $1 \mathrm{rPm}$ ). Animals were of uniform size $[\bar{x}+S D=75 \pm 14 \mu g$ ash free dry weight (AFDW), $N=29]$ and all appeared healthy during experiments. Before nftrogen release experiments, the copepods ( 4 animals for each food level bottle) were maintained for 18 to $22 \mathrm{~h}$ in $960 \mathrm{ml}$ volumes of aged sea water supplemented with various concentrations of food $\left(0,0.3,1.0\right.$, and $3.0 \mathrm{~m}^{3} \mathrm{I}$. fluviat1l1s $\left.11 \mathrm{ter}^{-1}\right)$ to simulate the range of phytoplanktor concentrations in upwellings on the southeastern shelf of 
the U.S.A. (Paffenhöfer et. al. 1980). Except for the unfed animals, all individuals had green guts at the beginning of ammonium release experiments. Ammonium release rates for individual copepods were measured kinetically (Gardner and Scavia 1981) over five successive 10-min intervals after food removal. Amonium (and amino acid) release rate patterns of six animals exposed to high food concentrations ( $3 \mathrm{~mm}^{3} \mathrm{I}$. fluviatilis liter ${ }^{-1}$ ) before Incubation were monitored at 10-min intervals for more than $4 \mathrm{~h}$ after food removal to provide detalled information on nutrient release over extcnded periods.

Ammonium release rates were estimated by measuring the quantity of ammonium accumulated over discrete periods (10 min) by individual animals in incubation flow cells $(0.05 \mathrm{ml})$. The cell was initially purged with fresh sea water ( $1.1 \mathrm{ml} \mathrm{min}^{-1}$ for $\left.1.5 \mathrm{~min}\right)$ to clear original culture water from the system. At 10-min intervals thereafter, the water in the cell was automatically displaced with fresh sea water and injected into an analyzer for ammonium and amino acid release measurements (Gardner and Scavla 1981). The ammonlum analyzer separated ammonium from amino acids by catiun exchange chromatography and reacted the isolated compounds with o-phthalaldehyde to form fluorescent derivatives (Gardner 1978). For this study, two incubation cells with corresponding analytical systems were operated in parallel (a Beckman 420 microprocessor controlled both units simultaneously). Animals frow each feeding treatment werc cxamined wilh both ayatems.

The effects of food concentrations, time after food removal, and analytical system on excretion rates were statistically evaluated for the 50-min experiments using a two-factor. ANOVA with repeated measure (hiner 1971; Dixon and Brown 1979). 
Mean zooplankton food ingestion rates for the different food concentrations were calculated from mean phytoplankton biomass removed from the feeding bottles $\left(\mathrm{mm}^{3} \mathrm{~T}\right.$. fluviatilis 1 iter $\mathrm{r}^{-1}$; Coulter Counter wethod of Paffenhöfer 1971), a nitrogen conversion factor of $1.14 \mathrm{Hg}^{-a t m} \mathrm{~N}$ per $\mathrm{mm}^{3} \mathrm{~T}$. fluviatilis, and the mean ing AFDW of experimental animals at each food level.

\section{RESULTS AND DISCUSȘION}

Experimental considerations. In agreement with previous observations on Daphnia magna (Gardner and Scavia 1981), confinement in the incubation flow cells did not appear to adversely affect Eucalanus pileatus. All animals survived the experiments and appeared to be in good physiological condition after removal, even after spending more than $6 \mathrm{~h}$ in the cells.

Although food level experiments were designed to examine the effects of food concentration and time (for 50 min after food removal) on mmonium release rates of $\underline{E}$. pileatus, the zero food concentrations also provided a way to differentiate "handling effects" from "food effects". Significantly $(p<0.01)$ elevated ammonium release rates were observed for all food concentrations during the first $10 \mathrm{~min}$ interval after removal from food (e.g., Table 1). Rates for this interval were about double the rates for the other intervals during the 50 min experiments. Because this was observed for unfed, as well as fed animals, we concluded that this initial elevated rate was likely due to experimental effects other than food; data from the first intervals were therefore not included in our excretion rate estimates. Exact reasons for these early elevated rates are unclear, but transferring animals into the flow cells may cause metabolic rates and amonium release rates to 
be 1ncreased. Alternatively the increased rates may reflect the animals' adjustments to the incubation flow cells or their reaction to the inftial purging of the cells with low-nutrient sea water.

Examination of data from both analytical systems indicated that one system yielded about 30\% lower excretion rates on average than the other for animals subjected to the same treatments. A posteriori considerations suggested that this apparent discrepancy was an analytical error caused by Inadequate time programed for sample injection into one of the ammonium analyzers. (Appropriate injection interval is derermined by ammonium analyzer buffer flow and injection loop size.) Since numbers obtained from this system therefore likely did not represent complete excretion rates, they were not included on Tables 1 and 2. However, because the injection error did not affect the relative patterns of nitrogen release for given animals, data froin both analytical systems were included in our statistical treatment of food and time effect on release rates; analytical system effects were cunslderèd as the second factor in a two-factor ANOVA with one repeoted measure (Winer 1971). Although rates were significantly lower for one system than the other, the ANOVA showed no evidence of interactions between eyotem effects and efther food level or time.

Ammonium release patterns. Except for the first 10-min intervals mentioned above, mean nitrogen release rates did not change significantly with time for any food concentration during the first 50 min after food removal. These results contrast with the pronounced progressively decreasing nitrogen (Gardner and Scavia 1981) and phosphorus (Peters and Rigler 1973) release rates observed for freshwater cladocerans during the first hour after food 
removal. These different excretion patterns may reflect physiological differences between taxa or differences in food composition or gut passage time. Because mean ammonium release rates (excluding data from the first interval) did not change significantly with time $(p>0.1)$ during the first 50 min for animals exposed to any of the food concentrations, we assumed these mean rates to be reasonable estimates of ammonium release rates for feeding animals. In agreement with data on other species (Corner et al. 1972; Takahashi and Ikeda 1975; Corner et al. 1976; Nelson et al. 1979), animals exposed to high concentrations of food released ammonium significantly $(p<0.05)$ faster than similar animals exposed to low or zero concentrations of food. However, the mean rate over 50 min (excluding the first interval) for E. 'pileatus exposed to the high food level of $3 \mathrm{~mm}^{3}$ Thalassiosira fluviatilis liter ${ }^{-1}\left(49 \mathrm{nmole} \mathrm{NH}_{4}(\mathrm{mg} A F D W)^{-1} \mathrm{~h}^{-1}\right.$ ) was less than double the mean rate for animals starved for 18-22 h (30 nmole $\mathrm{NH}_{4}$ (mg AFDW) ${ }^{-1} \mathrm{~h}^{-1}$; Table 1). Copepods exposed to intermediate levels of food $\left(0.3\right.$ and $1.0 \mathrm{~mm}^{3}$ algae liter ${ }^{-1}$ ) yielded mean excretion rates of 33 nmoles $\mathrm{NH}_{4}$ (mg. AFDW) ${ }^{-1} \mathrm{~h}^{-1}$. If dry weight to AFDW conversions are considered, our data for starved animals compare favorably with preliminary data we obtained previously (by the method descriher hy Gardner and Miller 1981) for individual E. pileatus fed on Rhizosolenia alata and then incubated without food for 6 to $8 \mathrm{~h}(\bar{x} \pm S E=23$ \pm 4 noole $\mathrm{NH}_{4}$ (mg dry weight) ${ }^{-1} \mathrm{~h}^{-1}, \mathrm{~N}=16$ ); unpublished data). Other data on E. pileatus were not avallable for comparison. Our release rates for $\underline{E}$. plleatus were typical of those reported for other marine zooplankters (Harris 1959; Beers 1964; Butler et al. 1969; Eppley et. al. 1973; Jawed 1973;

Conover and Mayzaud 1976; Szyper et al. 1976; Ikeda 1977; Sqith and whitledge 1977; Kremer 1977; and Biggs 1977), but exact comparisons are not weaningful 
because of differences in specles, animal sizes, and experimental methodology.

To compare nitrogen ingestion rates with measured ammonium excretion rates, we calculated the mean ingestion rates for zooplankters at each feeding level and compared them to the mean release races of the animals over the second through fifth 10 -min incubations after food removal (Table 2). In agrement with previous data on Calanus helgolandicus during $4 \mathrm{~h}$ incubations (Corner et al. 1976), the ratio of ammonium-N release rates to nitrogen ingestion rates progressively increased with decreasing food levels (Table 2). These data indicate that a relatively large fraction ( 40 to $>100 \%$ ) of nitrogen ingested by $\underline{E}$. pileatus is released as ammonium over comparable time intervals. After periods of low ingestion rates ( 0 or $24 \mathrm{ng}$-atm N (mg $A F D W)^{-1} h^{-1}$ in our experiments), the animals released nitrogen faster than they had been ingesting it during the pre-incubation periods. Although significant, ammonium release rates were only weakly related to ingestion rates (Table 2). As would be expected for "endogenous" (as contrasted to "fnod dependent") release, $\underline{E}$. pileatus continued to release substantial quantitiee of ammonium after extensive periods without food. In support of this observation, we have observed relatively continuous ammonium release by $\underline{E}$. pileatus in 6-ml vials over a period of 5 days after food removal (data not shown).

Our 4 to $6 \mathrm{~h}$ experiments allowed a detailed examination of the rate of change of nitrogen release rates with time after food removal. During these experiments, amonium release rates by $\underline{E}$. pileatus decreased with time, on average, for antmals fed high levels of food. If results from both analytical systems are included, the mean ammonium release rate ( $\pm S E$ ) of six 
animals for the $24 \mathrm{th} 10$ min interval ( $4 \mathrm{~h}$ after food removal) was $26 \pm 5$ as compared to a mean rate of $40 \pm 5$ noles $\mathrm{NH}_{4}$ (mg AFDW) ${ }^{-1} \mathrm{~h}^{-1}$ for the second through fifth intervals after food removal. Although ammonium release rates tended to decrease with time, release rate patterns varied among animals and were not entirely predictable (Figure 1). The slowly decreasing trends in release rates with time after food removal for some animals suggests that ammonium release by E. pileatus could be characterized into "endogenous" and "food related" mechanisms as was done for D. magna (Garoner and Scavia 1981), but that apparent food effects sometimes continue for several hours after food removal. The mean rate for a 10-min interval after 4-h incubations was similar to that obtained for animals starved for 18 to $22 \mathrm{~h}$ before the 50 -min experiments $\left(23 \pm 5\right.$ nmoles $\mathrm{NH}_{4}(\mathrm{mg} \text { AFDW })^{-1} \mathrm{~h}^{-1} ; \mathrm{N}=8$; mean rate for both analytical systems) and indicates that direct food effects on excretion occur within about $4 \mathrm{~h}$ of ingestion. The average rate of change of nutrient release with time was slower for E. pileatus than was previously observed for cladocerans (Peters and Rigler 1.973; Gardner and Scavia 1981).

The continued relatively high ammonium release rates for long periods (at least 5 days) after food was removed suggests that $\underline{\text { E. }} \underline{\text { pileatus may }}$ require frequent ingestions of food to malntain an adequate nitrogen balance. Assuming an. "endogenous" release rate of $30 \mathrm{ng}$-atm $\mathrm{N}$ (mg AFDW) $^{-1} \mathrm{~h}^{-1}$ ( $\mathrm{Table}$ 1) and a body content of $10 \mu g-a t m ~ N\left(m g\right.$ AFDW) ${ }^{-1}$ (based on a C to AFDW mass ratio of $0.5: 1$ and a $C$ to $N$ mass ratio of $3.6: 1)$, E. pileatus without food would lose half of its body nitrogen through ammonium refease in about 7 days at $20^{\circ} \mathrm{C}$. We have observed that E. pileatus cannot survive more than about 8 days in the laboratory without food. In agreement with this hypothesized need for frequent food ingestion, E. pileatus is rarely found in waters having low particle (phytoplankton) concentrations, but is frequently observed in particle-rich Gulf Stream intrusions. When occasionally encoun- 
tered in particle-poor environments, E. pileatus is physiologically weak and in a nonreproductive state (unpublished observations of $\underline{E}$. pileatus in waters off the southeastern U.S.A.). Thus $\underline{E}$. pileatus apparently cannot adequately adjust to long periods of low food conditions in nature. In contrast, some other species of copepods are more adaptable to periods of food shortáge. For example, the temperate copepod Calanus helgolandicus/pacificus (adult females) can survive in good condition for 3 weeks without food at $15^{\circ} \mathrm{C}$ (unpublished observation).

Amino acid release pallerns. Hatterns of p-phthalaldehyde-reactive amino acid release were followed, but not quantified, for $\underline{E}$. pileatus during the long-term experiments. Amino acid release rate patterns for these "well-fed" animals were pronounced and showed dramatic and unexpected variations during the course of the experiwents (Figure 1). Amlnn acids were generally released at very low rates (only slightly above analytical detection), but occastonally the release rates increosed euddenly to high, offscale levels for periods lasting from 20 to 60 min (Figure 1). Except for a few relativoly small amino acld peaks after tho high release events, awino acid levels in incubation vaters returned to almost undetectable levels soon after the events. The high-concentration amino acid spurts followed no recognizable time patterns relative to food removal, but were isolated and appeared to occur randomly. Four unt of the eix anidais yielded highconcentration amino acld spurts during these long-term expeziments. Since we did not examine fecal pellet release events, we could nor deterwine wherher they and the arino acid spurts were related.

Because levels of amino acids in these spurts were too high to quantify, we could not accurately estimate the relative levels of amino acids released during these events. Bowever, similar phenomena observed in our preliminary 
experiments with larger incubation volumes $(6 \mathrm{ml})$ allowed us to make relative comparisons of amino acid levels before and after the spurts. When ammonium and amino acid levels were monitored (by the method described in Gardner and Miller 1981) in $6 \mathrm{ml}$ volumes of filtered sea water surrounding individual E. pileatus (previously fed Rhizosolenla alata) over 6 to $8 \mathrm{~h}$ incubations, elevated peak heights from high-concentration amino acid spurts were observed on two occasions. During these events, respective levels of amino acids (based on relative heights of primary amine peaks) increased more than an order of magnitude over the "pre-spurt" levels that had accumulated over periods of 2 to $4 \mathrm{~h}$.

Amino acid release by marine invertebrates may account for a substantial portion (up to $25 \%$ of ammonium release) of dissolved nitrogen released by marine zooplankters (Webb and Johannes 1967; Kremer 1977), but the mechanism or kinetics of release have not been adequately examined. Based on the similar relative composition of released amino acids to those in intracellular pools, Webb and Johannes (1967) postulated that release by marine invertebrates could result from simple diffusion across cell membranes. Our data indicate that continuous diffusion is not the major mechanism of release for E. pileatus, but that most amino acid release occurs as occasional discrete events. The quantity, relative composition, and actual mechanism of release is not provided by our data, but the kinetic patterns of release are clearly demonstrated. The occurrence and frequency of these amino acid spurts among other species, their possible dependence on food level and quality, and the amounts of amino acids released to these spurts should be determined to assess their importance to nitrogen regeneration by warine zooplankters. Although difficult to demonstrate statistically, our results on these aminals suggest that ammonium release patterns may also be modified during 
the amino acid release events. Ammonium release appeared temporarily elevated and possibly more variable during the spurts than during periods of low amino acid release "(Figure 1). These increased ammonium release rates appeared to continue for a period after amino acid release had decreased to near background levels. More studies are needed to verify this tentative observation, but, if true, it could suggest changes in metabolic activity during and after the events.

\section{CONCLUUSIONE}

Depending on levels of food exposure prior to measurements, ammonium release rates after feeding were from 40 to more than $100 \%$ of the nitrogen ingestion rates over the previous several hours. Except for "experimentally Induced" elevations of ammonium release rates shortly after the animals were placed in the incubation flow cells, release did not change significantly with time during the first 50 min after food removal. In the course of several hours, however, the mean release rates for previously "well-fed" animals decreased in the absence of food down to about $60 \%$ of the mean rates observed soon after food removal. Continued high release rates after

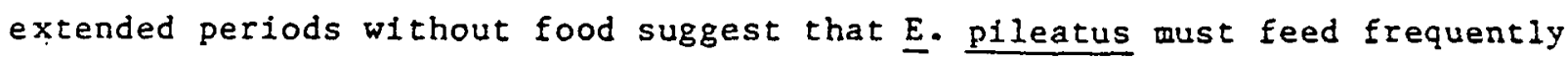
in nature to malntain an adequate nitrogen balance. In addition to ammonium, free amino acids were released by $\underline{E}$. pileatus in occasional large spurts extending over periods of 20 to $60 \mathrm{~min}$. The mechanism of release and the guantity of nitrogen in these spurts should be evaluated to assess their importance to copepod nitrogen regeneration processes in marine ecosystems. 


\section{ACKNOWLEDGEMENTS}

The authors are grateful to S. C. Knowles for help with preliminary excretion experiments, to $L$. R. Herche for conducting the ANOVA's and helping interpret statistical results, and to D. Scavia and H. A. Vanderploeg for suggestions on the manuscript. This research was supported by NSF grant OCE79-25055 and DOE Contract DE-ASO9-76EV00936. 


\section{REFERENCES}

Beers, J.R.: 1964. 'Ammonia and inorganic phosphorus excretion by the planktonic chaeognath, Sagitta hispida Conant'. J. du Conseil Internat. pour l'exploration de la Mer. 29, 123-129.

Biggs, D.C.: 1977. 'Respiration and ammonium excretion by open ocean gelatinous zooplankton'. Limnol. Oceanogr. 22(1), 108-117.

Butler, E.I., Corner, E.D.S., and Marshall, S.M.: 1969. 'On the nutrition and metabolism of zooplankton. VI. Feeding efficiency of Calanus in terms of nitrogen and phosphorus'. J. Mar. Biol. Ass. U.K. 49, 977-1001.

Conover, R.J., and Mayzaud, P.: 1976. 'Respiration and nitrogen excretion of neritic zooplankton in relation to potential food supply'. In European Symposium on Marine Biology, 10th, Ostend, Belgium, September 17-23, 1975. Vo1. 2: Population Dynamics. Universa Press, Wetceren, Belgium. Pp 151-163.

Corner, E.D.S., Head, R.N., and Kilvington, C.C.: 1972. 'On the nutritfon and metabolism of zooplankton. VIII. The grazing of Biddulphia cells by Calanus helgolandicus'. J. Mar. Biol. Ass. U.K. 52, 847-861.

Corner, E.D.S., Head, R.N., Kilvington, C.C.', and Pennycuick, I.: 1976. 'On the nutrition and metabolism of zooplankton. X. Quantitative aspects of Calanus helgolandicus feeding as a carnivore'. J. Mar. Biol. Ass. U.K. $56,345-358$.

Corner, E.D.S., and Newell, B.S.: 1967. 'On the nutrition and metabolism of zooplankton. IV. The forms of nitrogen excreted by Calanus'. J. Mar. Biol. Assoc. U.K. 47, 113-120. 
Dixon, W.J., and Brown, M.B.: 1979. BMDP 79. Biomedical Computer Programs P-Series. University of Calffornia Press, Program P2V.

Eppley, R. W., Renger, E. H., Ventrick, E. L. and Mullin, M. M.: 1973. 'A study of plankton dynamics and nutrient cycling in the central gyre of the North Pacific ocean'. Limnol. Oceanogr. 18(4) 534-551.

Gardner, W.S.: 1978. 'Microfluorometric method to measure ammonium in natural waters'. Limnol. Oceanogr. 23(5), 1069-1072.

Gardner, W.S., and Scavia, D.: 1981. 'Kinetic examination of nitrogen release by zooplankters'. Limnol. Oceanogr. 26(5), 801-810.

Gardner, W.S., and Miller, W.H. III: 1981. 'Intracellular composition and net release rates of free amino acids in Daphnia magna' Can. J. Fish. Aquat. Sci. $38,157-162$.

Harris, E.: 1959. 'The nitrogen cycle in Long Island Sound.' Bulletin of the Bingham Oceanographic Collection Yale University 17, 31-65.

Ikeda, T.: '1977. "The effect of laboratory conditions on the extrapolation of experimental measurements to the ecology of marine zooplankton. IV. Changes in respiration and excretion rates of boreal zooplankton species maintained under fed and starved conditions.' Marine Biol. 41, $241-252$

Jawed, M.: 1973. 'Ammonia excretion by zooplankton and its significance to primary productivity during summer'. Marine B101. 23, 115-120.

Johannes, R.E., and Webb, K.I.: 1965. 'Release of dissolved amino acids by marine zoopiankton'. Science 150, 76-77.

Kremer, P.: 1977. 'Respiration and excretion by the ctenophore Mneplopsis leid1'. Marine Biol. 44, 43-49. 
Lehman, J.T.: 1980. 'Release and cycling of nutrients between planktonic algae and herbivores'. Limnol. Oceanogr. 25(4), 620-632.

McCarthy, J.J., and Goldman, J.C.: 1979. 'Nitrogenous nutrition of marine phytoplankton in nutrient-depleated waters'. Science 203, 670-672.

Nelson, S.G., Simmons, M.A., and Knight, A.W.: 1979. 'Ammonia excretion by the benthic estuarine shrimp Crangon franciscorum (crustacea: crangonidae) in relation to diet'. Marine Biol. 54, 25-31.

Paffenhöfer, G.A.: 1971. 'Grazing and ingestion rates of nauplii, copepo'dide and adulte of the marine planktonic copepod Calanuo helgolandicus'. Marine Biol. 11, 286-298.

Paffenhöfer, G.A., Deibel, D., Atkinson, L.P., and Dunston, W.M.: 1980. 'The relation of concentration and size distribution of suspended particulate matter to hydrography in Onslow Bay, North Carolina. Deep-Sea Research 27A, 435-447.

Paffenhöfer, G.A., and Knowles, S.C.: 1978. 'Feeding of marine planktonic copepods on mixed phytoplankton'. Marine Biol. 48, 143-152.

Pctcr3, R.H., and Riglcr, F.H.1 1973. 'Phosphorus relcasc by Daphnia'. Limnol. Oceanogr. 18(6), 821-839.

Smith, S.L.: 1978. 'The role of zooplankton in the nitrogen dynamics of a shallow estuary'. Estuar. Coast. Mar. Sci. 7, 555-565.

Smith, S.I., and Whitledge, T.E.: 1977. 'The role of zooplankton in the regeneration of nitrogen in a coastal upwelling system in northwest Africa'. Dép-Sea Research 24, 49-56.

Szyper, J.P., Hirota, J., Caperon, J., and Ziemann, D.A.: 1976. 'Nutrient regeneration by the larger net zooplankton in the Southern Basin of Kaneohe Bay, Oahu Hawailan Islands. Pacific Science 30, 351-361. 
Takahashi, M., and Ikeda, T.: 1975. 'Excretion of ammonia and inorganic phosphorus by Euphausia pacifica and Metridia pacifica at different concentrations of phytoplankton'. J. Fish. Res. Board Can. 32(11), 2189-2195.

Webb, K.L., and Johannes, R.E.: 1967. 'Studies of the release of dissolved free amino acids by marine zooplankton'. Limnol. Oceanogr. 12, $376-382$.

Winer, B.J.: 1971. Statistical Principles in Experimental Design. 2nd Ed. McGraw-Hill, New York, 907 pp. 
TABLE 1

Mean annonium release rates $\pm \mathrm{SE}\left[\right.$ nmoles $\mathrm{NH}_{4}(\mathrm{mg} \mathrm{AFDW})^{-1} h^{-1}$ ]

of Eucalanis pileatus at $20^{\circ} \mathrm{C}$ for five successive $10 \mathrm{mda}$ intervals

after exposure to four levels of food for 18 to $22 \mathrm{~h}$.

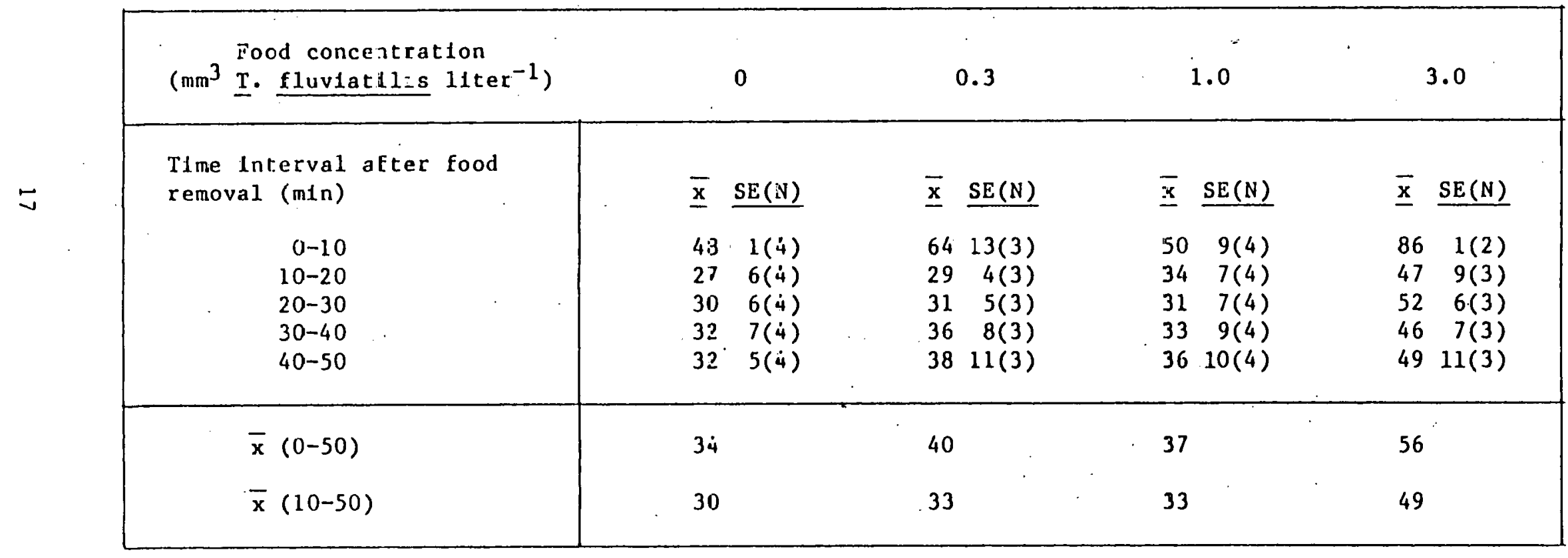


TABLE 2

Comparison of mean nttrogen ingestion rates

and mean ammonfum release rates for Eucalanus p1leatus

exposed to four levels of Thalassiosira fluviatilis at $20^{\circ} \mathrm{C}$.

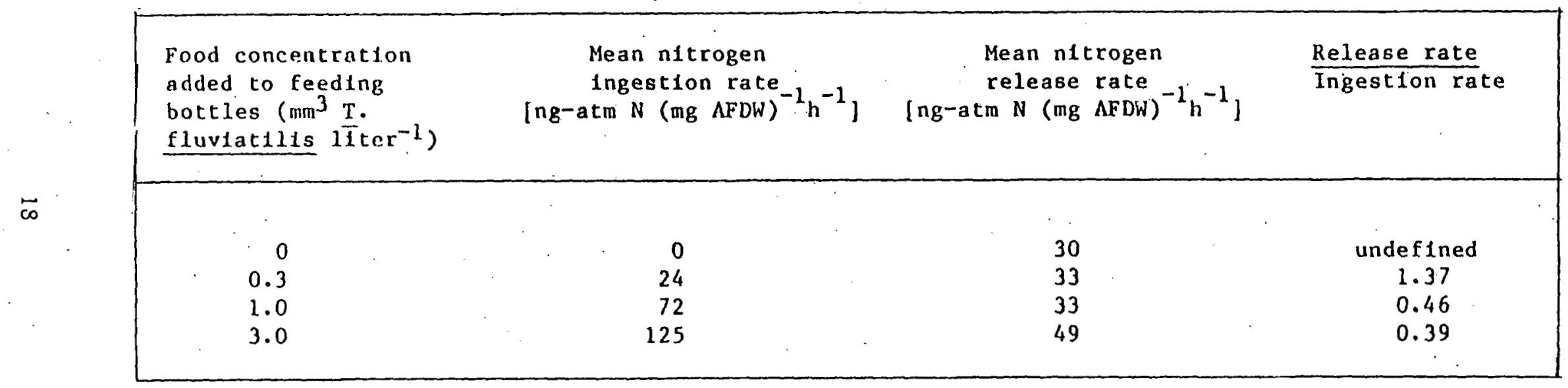




\section{LIST OF FIGURES}

Figure 1. Patterns of ammonium and o-phthalaldehyde-reactive amino acid nitrogen release with time after feeding for six individual $\underline{\text { Eucalanus pileatus fed on } 3 \mathrm{~mm}^{3} \text { Thalassiosira fluviatilis liter }}{ }^{-1}$ for 18 to $22 \mathrm{hr}$. Ammonium was not determined for the first inter$\mathrm{val}$ of the $100.4 \mathrm{~g}$ animal because of recorder malfunction. The magnitude of release rates reported for the $79.2,80.0$, and $84.0 \mu \mathrm{g}$ AFDW animals may be low because of incomplete sample injections (see text). 


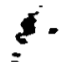
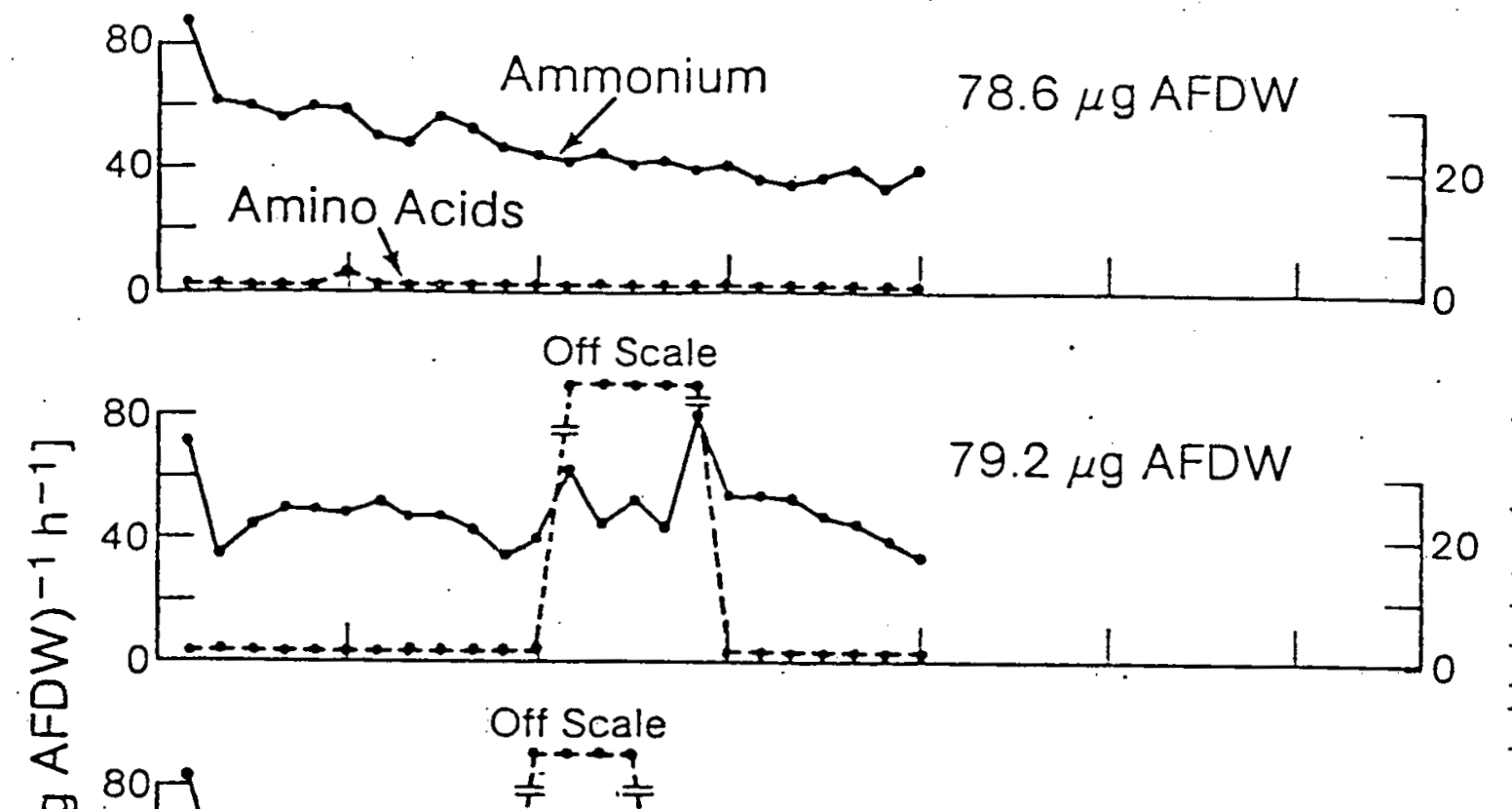

है

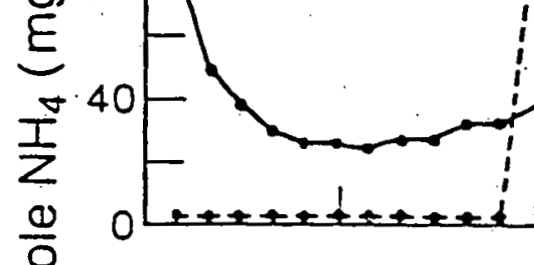

ํㅡㄹ

E

80

$\frac{9}{\pi}$

悉

$\Phi$

๘

$\frac{\mathscr{O}}{\mathscr{Q}}$

(1)

$\frac{\pi}{5}$

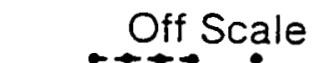

$80 \div-\frac{1}{1}$

E

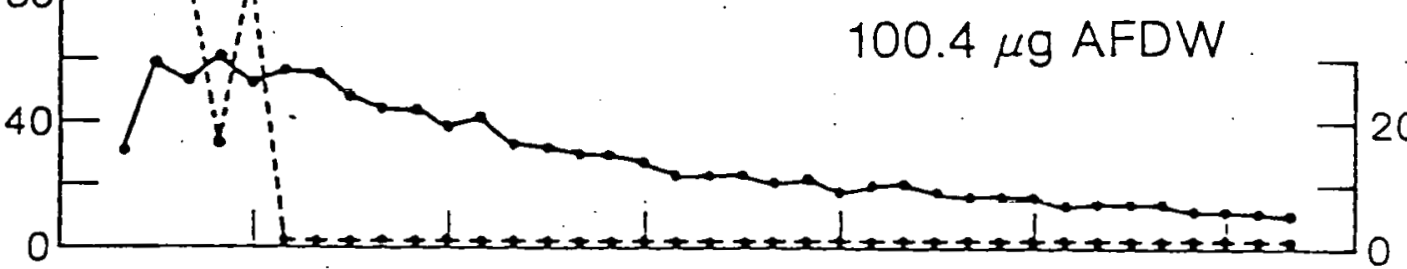

$80.0 \mu \mathrm{g} \mathrm{AFDW}$

$72.9 \mu \mathrm{g}$ AFDW

\section{Off Scale}

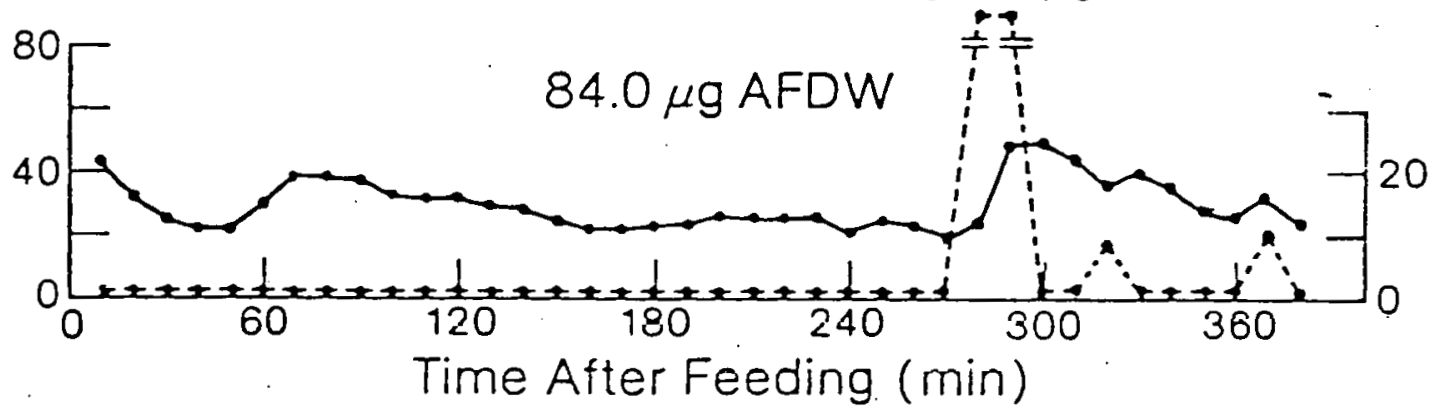

Figure 1

$$
-20-
$$




\title{
CALANOID COPEPOD FEEDING: GRAZING ON SMALL AND LARGE PARTICLES
}

\author{
BY \\ A.?. \\ Gustav-Adolf Paffenhöfer
}

Skidaway Institute of Oceanngraphy

P.0. Box 13687

Șavannah, Georgia 31406

presented at: Trophic Dynamics of Aquatic Ernsystems AAAS Symposium, Toronto, Canada, 1981 
Removal of phytoplankton cells by adult females of the calanoid copepods Eucalanus pileatus and Paracalanus sp., when simultaneously offered cells of 3 different sizes, were determined over 48h. Concentrations of the 2 larger algae were reduced below $0.05 \mathrm{~mm}^{3} \cdot \ell^{-1}$ without large changes in grazing rates. Only Paracalanus removed significant amounts of the smallest alga. While copepods from temperate waters reduce their grazing rates when metabolic costs cannot be met, the 2 subtropical copepods studied here feed at near maximum rates even when their metabolic costs cannot be met. Thus, it appears that not only algal concentration, but also algal size determines the feeding thresholds of copepods which reduce removal rates as smaller particles ( $\leq 6 \mu m$ ) are eaten. These findings are based on visual counts of cells. Electronic counts overestimate the amount of phytoplankton-present as the experiments advance in time. 


\section{INTRODUCTION}

The basic goal of most quantitative zooplankton feeding studies is to understand events which occur in the ocean but cannot be accurately determined in situ. Experiments are designed to answer important environmental questions, one of them being: At what rates are particles of different sizes ingested by copepods? All feeding studies covering the entire particle spectrum have been conducted so far with naturally occurring particulate mattor.

Poulet (1978) showed that 5 species of neritic copepods removed large quantitites of particles in a size range from 2.5 to $60 \mu m$ diameter at equal rates. However, Koeller et ai. (1979) found that female Pseudocalanus minutus, a species used by Poulet (1978) removed only particles larger than $6 \mu \mathrm{m}$ diameter. In both studies the concentrations of copepods used ranged from 50 to $100 \cdot \ell^{-1}$, at least one order of magnitude higher than found in nature. Also, because their conclusions were based on one measurement at the beginning and one at the end of the 24 h experiments information was not obtained on possible changes in feeding sequences on different particle sizes or on changes in feeding rates with time. Richman et al. (1980) and Roman and Rublee (1980) obtained intermediate measurements. Richman et al. (1980) showed that grazing rates on particles larger than $8 \mu m$ remained even throughout the cxpcriments for Diaptomus orcgonensis and decreased moderately for Diaptomus siciloides. Both copepods started feeding on particles smaller than $8 \mu m$ as the experiments progressed. In contrast, in $48 \mathrm{~h}$ experiments 
Acartia tonsa drastically reduced its grazing rate after $12 \mathrm{~h}$ and rates continued to decrease moderately for the next $36 \mathrm{~h}$ (Roman and Rublee, 1980). The results of Richman et al. (1977) using A. tonsa and Eurytemora herdmani tend to support those of Roman and Rublee (1980) who found that at low copepod densities $(5 / 180 \mathrm{ml})$ highest grazing rates were obtained (for particles $>10 \mu \mathrm{m})$, that rates dropped sharply at the next higher density $(10 / 180 \mathrm{ml})$ and remained low at all higher concentrations.

Discrepancies between the findings of Poulet (1978) and Koeller et al. (1979) and between Richman et al. (1980) and Roman and Rublee (1980) prompted the experiments described here. These experiments were designed to determine how copepods feed over extented time in phytoplankton patches when the concentration of phytoplankton and temperature of water masses upwelled during sumer on the southeastern continental shelf (SE-shelf) of the U.S.A. were simulated.

The specific objectives/questions of this study were:

1. to determine if particles of $6 \mu \mathrm{m}$ and $>10 \mu \mathrm{m}$ diameter are eaten simultaneously or consecutively. The former should be assumed from Poulet's (1978) result. However, cinematography techniques (Paffenhöfer; Strickler and Alcaraz, unpubl.) show that Eucalanus pileatus females use different feeding modes for small (<6um) ano large $(>10 \mu m)$ particles.

2. to determine if grazing rates (volume swept clear $\cdot \operatorname{copepod}^{-1} \cdot$ day $^{-1}$ ) on various food sizes change when food concentrations decrease. 
3. to determine if thresholds occur at low food concentration. Several authors found feeding thresholds under different conditions (Corner et al. 1972, Frost 1975, Gamble 1978) and stressed the importance (Steele 1974) or limited importance (Landry 1976) of these thresholds. In my experiments copepods were allowed to reduce the phytoplankton to near or below the concentration at which assimilation approximately equals basic metabolic expenditures.

4. to compare determinatiuns of cell concentration obtained by electronic and visual counting techniques. This type of comparison tells whether, and to what extent, particle production occurs in the size range of the phytoplankton cells offered and should help to determine the extent of particle production while copepods feed (Frost 1977, Richman et al. 1980). As earlier cited, most feeding studies have been based on electronic particie counts (for a critical evaluation see Harbison and MCAlister, 1980) and comparisons of electronic and visual counts are needed. 
MATERIAL AND METHODS

Experiments were conducted with late copepodid stages and adult females of laboratory-reared Paracalanus sp. and field-collected Eucalanus pileatus. The food initially offered consisted of equal volume concentrations of Thalassiosira pseudonana ( 6 to $6.5 \mu \mathrm{m}$ equivalent spherical diameter=ESD),

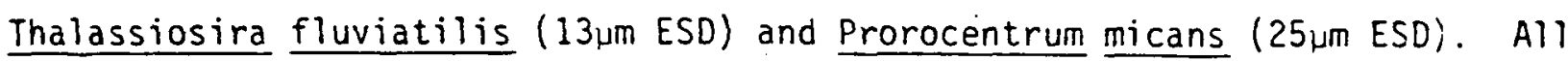
experiments were started with a nominal concentration of approximately $0.5 \mathrm{~mm}^{3} \mathrm{~L}^{-1}$ of each algal species. The experimental vessels were jars of $1900 \mathrm{ml}$ capacity and controls held $960 \mathrm{ml}$. The concentrations of animals used were 32 to 45 Paracalanus or 12 to $17 \mathrm{E}$. pileatus per liter. The total mass of each species was approximately equal. Paracalanus is usually the most abundant zooplanktonic genus on the SE-shelf; E. pileatus is abundant in upwelled water masses which intrude onto the SE-shelf during summer (Paffenhöfer 1980).

Food concentrations in control and experimental vessels were determined

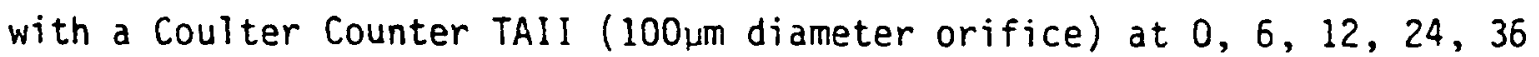
and $48 \mathrm{~h}$ and by inverted microscope at $0,12,24,36$ and $48 \mathrm{~h}$ after the start of each experiment. The temperature was constant at $20^{\circ} \mathrm{C}$ and animals and food were exposed to $14 \mathrm{~h}$ light and $10 \mathrm{~h}$ darkness. Algae were added to the cunlainers $16 \mathrm{~h}$ before the start of the experiments. The water had previously contained copepods for preconditioning, was filtered through $0.8 \mathrm{im}$ membrane filters and enriched with $\frac{f}{10}$ medium $\left(2 \mu \mathrm{g}-\mathrm{at} \cdot \ell^{-1}\right.$ of ammonia) to allow the algae to grow. Copepods were adapted to the 3 algal species by keeping them for $48 \mathrm{~h}$ at food concentrations with appropriate cell mixtures close to those used in the experiments. Each time food concentrations were measured 
55 to $70 \mathrm{mi}$ were removed by pipette and this volume was replaced with $0.8 \mu \mathrm{m}$ membrane-filtered seawater. From the volume of water added the new concentration of each food species was calculated. Dilution was between 3 to $6.5 \%$. From each sample withdrawn 2 subsamples of $5.0 \mathrm{ml}$ or $22.0 \mathrm{ml}$ were preserved with Lugol's solution, placed in settling chambers and counted by inverted microscope 14 to $20 \mathrm{~h}$ later. The remainder of each subsample was used to make at least 2 replicate Coulter counts within 30 min of withdrawing the sample. The algal species used could be clearly distinguished from each other in separate channels. At the end nf each $48 \mathrm{~h}$ experiment the surviving copepods were collected, counted, staged and dried to determine ash-free dry weights. Copepod mortality was always below $12 \%$ over $48 \mathrm{~h}$. Dead or weak animals were removed as soon as detected.

To compare Coulter Counter and microscope counts, the cells visually counted were multiplied by average cell volumes which were $125 \mu^{3}$ (I. pseudonana), $1620 \mathrm{\mu m}^{3}$ (I. fluvidtilis) and $7200 \mathrm{\mu m}^{3}$ (․ micans). Particle concentrations in the environment were determind with a Coulter Counter Model TAll with 100 and 400 um diameter orifices. 


\section{RESULTS}

I conducted 3 experiments with each species of copepod. As somewhat different stages and algal concentrations were used for each experiment, feeding rates and decreases in food concentrations differed over time. Thus, the experiments are discussed separately.

In each $48 \mathrm{~h}$ experiment concentrations of $\underline{T}$. fluviatilis and $\underline{P}$. micans decreased to below $0.05 \mathrm{~mm}^{3} \cdot \Omega^{-1}$, here shown (Figs. 1 and 2) for one experiment each with the two species of copepods. E. pileatus removed few T. pseudonana $(6 \mu \mathrm{m})$ whereas Paracalanus ingested considerable amounts of this species when the combined concentrations of the 2 larger algae were reduced to below $0.2 \mathrm{~mm}^{3} \cdot \mathrm{l}^{-1}$

Electronic and visual counts of $I$. pseudonana compared quite well in both experiments. The Counter Counter, however, overestimated the concentration of $\underline{T}$. fluviatilis and $\underline{P}$. micans when their concentrations reached levels near or below $40 \%$ of that initially present (Figs. 1 and 2 ). The electronic counter data for the 2 larger algae were 145 to $900 \%$ higher than those of visual counts at concentrations below $0.1 \mathrm{~mm}^{3} \cdot \ell^{-1}$. Differences were less for $\underline{P}$. micans-than for I. fluviatilis. At the beginning of the experiments the number of cells $\cdot \mathrm{ml}^{-1}$ measured with the coulter counter and the inverted microscope differed by 3 to $7 \%$.

Grazing rates (volume swept clear.copepod-1.day-1) corrected for algal growth (Frost 1972), served to indicate how feeding effort changed during the $48 \mathrm{~h}$ experimental period. Visual counts showed a slight decrease of the 
feeding rate of $\underline{E}$. pileatus females ( $39 \mu \mathrm{\mu g}$ ash free dry weight) on I. fluviatilis, increased consumption of $\underline{P}$. micans and little change for $\underline{T}$. pseudonana (Fig. 3). To compare rates derived from electronic and visual counts, the electronic counts for hours 0 to 6 and 6 to 12 were averaged. Rates based on electronic and visual counts compared well for $\underline{P}$. micans only during the first 24h. All grazing rates based upon electronic data for I. fluviatilis and for the second $24 \mathrm{~h}$ for $\underline{\mathrm{P}}$. micans are considerably below the visually obtaincd data.

Grazing rates of Paracalanus sp. females ( $8.6 \mu g$ ash-free dry weight) based on electronic counts were close to visual data for I. pseudodonana throughout the experiment and for I. fluviatilis and $\underline{P}$. micans for the first $12 \mathrm{~h}$ (Fig. 4). After $12 \mathrm{~h}$ visually obtained rates considerably exceeded those from the Coulter Counter. Grazing rates based on visual counting of $\underline{P}$. micans and $I$. pseudonana increased with time whereas those on $I$. fluviatilis vere higher during the night than during the day.

To obtain a more complete understanding of the above observations, grazing rates derived from visual counts in 2 other experiments are presented in Fig. 5. The feeding rates of E. pileatus (Copepodid stages IV and $V$ weighing on the average-25ug ash-free) on $I$. fluviatilis and $\underline{P}$. micans increased similarly during the first $12 \mathrm{~h}$ followed by a decrease of $10 \%$ (I. fluviatilis) and $16 \%$ ( . micans) during the $36-48 \mathrm{~h}$ period. Feeding rates on $I$. pseudonana increased as concentrations of the 2 larger algae decreased. 
Grazing rates of Paracalanus sp. females ( $7.7 \mu \mathrm{g}$ ash-free dry weight) on I. fluviatilis and $\underline{P}$. micans again changed with the time of day (Figs. 4 and 5). In this experiment (Fig. 5) Paracalanus reduced the 2 large algae to the limits of detection in large settling chambers $(22 \mathrm{ml})$. The average concentrations of the 2 larger algae were, $0.2 \mu \mathrm{g} \mathrm{C.S.-1}$ (I. fluviatilis) and. $1.7 \mu \mathrm{g} \mathrm{C} \cdot l^{-1}$ (P. micans) during the final 12 hours. As in the 2 other experiments with Paracalanus there was a marked increase of grazing rate on I. pseudonana when the combined volumetric concentration of the larger cells dropped to about 20\% of the total algal volume (Fig. 6). Grazing rates of $\underline{E}$. pileatus females on $\underline{I}$. pseudonana changed littie during the experiments; copepodid stages IV/V of the same species increased their consumption of this small algae as concentrations of the larger phytoplankton decreased. 


\section{DISCUSSION}

Feeding on Small and Large Particles:

Female E. pileatus and Paracalanus sp. reduced $\underline{I}$. fluviatilis $(11-14 \mu \mathrm{m}$ equivalent spherical diameter $=E S D$ ) and $\underline{P}$. micans $(25 \mu \mathrm{m} E S D)$ to as low as 0.3 cells $\cdot \mathrm{ml}^{-1}$. E. pileatus females ingested only small amounts of $\underline{T}$. pseudonana ( $6 \mu \mathrm{m}$ ESD) even when the combined concentrations of the 2 larger algae dropped to $0.05 \mathrm{~mm}^{3} \cdot \ell^{-1}$. Paracalanus, however, considerably reduced the conccntration of I. pseudonana when the larger algae were reduced to $0.2 \mathrm{~mm}^{3} \cdot \ell^{-1}$ or less (Fig. 5). This means that large algae must be quite low in volumetric concentration before Paracalanus females start eating significant amounts of algae of 6 um or less in diameter. This agrees with observations of Richman et al. (1977, 1980) on Acartia tonsa, Eurytemora affinis, Diaptomus siciloides and Diaptomus oregonensis.

My studies show. that copepods always remove algae larger than 10um ESD at much higher rates than cells <6um when both sizes of cells are equally abundant by volume. In contrast, Poulet (1978) showed that small and large particles were removed at similar rates. Poulet's experimental concentrations of 50 to 100 adult copepods. $\rho_{-1}^{-1}$ exceed natural densities by about one order of magnitude. Thus, large particles were removed at least 10 times faster than in the sea. This resulted in unnaturally low concentrations of large particles after a relatively short feeding period leading to the incestion of small particles by the copedods. Such raptd depletion of large darticles shoul not occur in the sea at natural concentrations of adult copepods although 
they preferentially remove large particles (Koeller et al. [1979] using female Pseudocalanus minutus; Richman et az. [1980] using Diaptomus siciloides, their figs. 3 and $3 a$ ). It would also be ecologically unfavorable if reproducing females intensively competed with juveniles of the same species for the same food size. In my opinion, adults only resort to feeding on small particles when larger particles have been depleted. Reduced feeding rates on small particles prevents exhaustion of food which is so important to nauplii (Paffenhöfer and Knowles 1978). Here particle size dictates feeding threshold of adult copepods.

However, there may be exceptions when smaller particles are removed at higher rates than large ones. For example, Small and Donaghay (1979) demonstrated that Acartia clausii removed small and large algae and ignored intermediate sized plastic spheres. Acartia, and probably many other calanoids possess non-mechanical means to select particles. From Friedman and Strickler (1975) and recent unpublished observations by Dr. Rudolf Strickler one concludes that calanoids may select cells 'by chemosensory perception. argans located on mouthparts sense chemicals which constitute phycospheres surrounding the cells (Bell and Mitchell 1971). If large particles in Poulet's (1978) experiments consisted of mostly detritus and relatively few algae the copepods, after detecting and removing the algue by chemosensory perception, would have turned their attention to small particles (perhaps flagellates): Larger algal cells would have been rapidly depleted resulting in a relatively high ingestion rate of small over large particles. 
Grazing Rates and Feeding Thresholds:

The concept of threshold concentrations below which feeding does not occur has been addressed in various experimental studies. Corner et al. (1972) showed a marked decrease in volume swept clear by Cananus helgolandicus when concentrations of Biddulphia sinensis ( $>60 \mu m$ diameter) were at or below 500 cells $\cdot \ell^{-1}$. Frost (1975) demonstrated a reduction of about $50 \%$ in clearance rates by adult female calanus pacificus when concentrations of Thalassiosira fluviatilis ( $13 \mu \mathrm{m}$ diameter) were about $150 \mathrm{cel} 1 \mathrm{~s} \cdot \mathrm{m}^{-1}$. The filtration rates of Acartia tonsa decrease from maximum to near zero as phytoplankton concentrations decrease from 10 to near 0.2 to $0.5 \mu \mathrm{g}$ chlorophyli-a: $\ell^{-1}$ (Reeve and Walter 1977). Using particulate matter (PM) from the sea Adams and Steele (1966) showed marked reductions of grazing rates of Calanus finmarchicus at PM concentrations below $150 \mathrm{\mu g} \mathrm{C} \cdot \mathrm{l}^{-1}$. Calanus plumchrus, Calanus pacificus and Pseudocalanus minutus did not feed when PM concentrations were reduced to 50 and $190 \mu \mathrm{g} C \cdot l^{-1}$ (Parsons et ai. 1969). Roman and Rublee (1980) observed that grazing rates of Acartia tonsa copepodid stage $V$ and adults feeding on particulate matter from nearshore decreased over a period from 3 to $8 \mathrm{~h}$. My experiments showed the Paracalanus and Eucalanus pileatus reduced phytoplankton cells of 13 and $25 \mu \mathrm{m}$ ESD from more than $300 \mathrm{cells} \cdot \mathrm{ml}^{-1}$ to below $1 \mathrm{cell} \cdot \mathrm{m} \ell^{-1}$ without a marked reduction in grazing rate.

Because of these different findings the following questions may be addressed: 1. Why are grazing rates reduced over time (Roman and Rublee, $1980), 2$. What could cause the copepods to almost cease feeding at low food concentrations, and 3 . Why can grazing rates be maintained as particle concentrations decrease, or: must there be threshoid concentrations of iond? 
1. Using high-speed cinematography I have observed that phytoplankton cells of 10 to $13 \mu \mathrm{m}$ diameter (I. fluviatilis) and larger are "individualiy" removed from the surrounding water by $\underline{E}$. pileatus. The second maxillae are used to transport the cells in a parcel of water to the mouth. When cells of $6 \mu \mathrm{m}$ diameter and smaller. are present at concentrations of $10,000 \mathrm{ce} 11 \mathrm{~s}$. $\mathrm{ms}^{-1}$ or less $\underline{E}$. pileatus does not employ "individual" feeding mode but rather appears to use a not yet fully understood and less efficient "filtration" mode. Grazing rates on smafl, compared to large cells under this condition are very low. I assumie that when large $(>10 \mu \mathrm{m})$ particles become less abundant in the spectrum of particulate matter available to copepods (i.e., 2 to $32 \mu \mathrm{m}$ ) that grazing rates on the total particulate matter decreases as small particles become more abundant $=$ when the number of large cells is reduced relatively fewer particles are removed by the "individual". (high rate) and more by the "filtration" (low rate) mode.

When visual counts showed that large cells were depleted the electric particle counter still showed a considerable number of such particles. These were either artifacts or represented particles which do not trigger a feeding response by the copepod. Figures 3 and 4 show that feeding rates on $I$. fluviatilis and $\underline{P}$. micans between hours 24 to 48 are far higher than estimated by Coulter Counter measurements of particles in the size range of these algae. Figures 1 and 2 show that many particles were produced in the experimental jars. Thus, tine dependant reductions in overall grazing rate observed by Roman and Rublee (1980) could have been due to: (1) small particles becoming relatively more abundant as large particles were removed; (2) the production 
of particles lead to underestimates of grazing rates based on electronic counts; and (3) particles of terrestrial origin found in nearshore waters may not trigger a feeding response by calanoid copepods. Terrestrial detritus has low nutritive value (Tenore 1981).

2. For a copepod to ingest particles feeding responses must be triggered. Cinematographic observations and experimental studies show that particles are efficiently removed when $\underline{\underline{E}}$. pileatus and Paracalanus use their second maxillae (Paffenhöfer, Strickler and Alcaraz, unpubl. observations). There may be considerahle amnunts of particulate matter in the water and no measurable feeding response. The lowest concentration of particulate matter we have measured on the SE-shelf was $0.28 \mathrm{~mm}^{3} \cdot \ell^{-1}$ (Fig. 7), with chlorophyll-a concentrations below $0.1 \mu \mathrm{g} \cdot \ell^{-1}$. From my findings (Figs. $I$ and 2), where electronically measured volumes were $145-900 \%$ higher than observed visually, one could assume that most of the particles measured (Fig. 7), were not phytoplankton and were not removed by copepods which were abundant (Paffenhöfer, unpubl, observations). Otherwise particle concentrations in the sea - at least for $>10 \mu \mathrm{m}$ ESD should be lower, approaching values found visually in my experiments.

3. Feeding thresholds are food levels below which feeders reduce or cease feeing. The ecological cignificance of thresholds is to provont r.nmplete depletion of a food source, i.e., maintain survival (Steele 1974). In experiments with Paracalanus sp. and $\underline{E}$. pileatus I observed no concentration thresholds, in contrast to the studies by Corner et az. (1972) and the other authors referenced earlier. To attempt to explain this discrepancy 1 com- 
pared metabolic expenditures with the food assimilated (Table 1) and then compare copepods behaviour in their natural environment. The approach has limitations as there are no respiration data available on actively feeding specimens of the species 1 used. However, applying respiration rates for wild C. helgolandicus (pacificus) (Mullin and Brooks 1970) I calculated metabolic expenditures for $\underline{\underline{C}}$. helgolandicus and $\underline{E}$. pileatus females (transforming CIV data to $20^{\circ} \mathrm{C}$ ). Expenditures were also calculated from Ivleva (1980). The assimilated food was then calculated using a $35 \%$ assimilation efficiency for $\underline{C}$. helgolandicus (Vidal, 1980, his Table 1) and 90\% for E. pileatus and Paracalanus at $20^{\circ} \mathrm{C}$ (extrapolating roughly from Vidal 1980). The calculations (Table 1 ) indicate that when $\underline{C}$. helgolandicus reduces its grazing rates at cell concentrations below $32 \mu \mathrm{g} \mathrm{C} \cdot \ell^{-1}$ its metabolic expenditures are no longer met. Paracalanus can meet its metabolic needs when food concentrations of $66 \mu \mathrm{g} C \cdot l^{-1}$ were reached during the second 24 hours of my experiments, whereas $E$. pileatus cannot (Table 1 ).

E. pileatus is abundant on the S.E.continental shelf only when relatively high concentrations $\left(>1 \mathrm{~mm}^{3} \cdot l^{-1}\right)$ of large algae (Rhizosolenia sp., e.g., 15 to $120 \mu \mathrm{m}$ cell width) are found. Without large particles it (E. pileatus) seemingly cannot exist as unlike some temperate species it stores few wax esters. Thus, to minimize metabolic losses it continues to graze intensively at low levels (Lam and Frost 1976). Paracalanus is abundant when cell concentrations are as low as $0.5 \mathrm{~mm}^{3} \cdot \ell^{-1}$ ( 2 to $100 \mu \mathrm{m}$ diameter) as it can obtain sufficient energy from small particles (Figs. 4 and 5). For these animals there is no refuge in shallow subtropical waters of $20^{\circ}$ to $29^{\circ} \mathrm{C}$ other than to migrate vertically to find food or to minimize metabolic losses by continued grazing at high rates. 
In contrast, temperate copepods like Calanus helgolandicus, store energy (Lee et al. 1971) and can, in times of food shortage, migrate to deeper, colder waters where metabolic expenditures are sharply reduced; or, if low food concentrations are found in shallow areas metabolic losses can be temporarily compensated by using stored enerçy reserves:

My study attempted to determine, by simulation, how adult females of Paracalanus and E. pileatus feed in upwelled water mass initially rich in phytoplankton and low in detritus. This situation is common during summer on the SE-shelf. In such water masses females of the 2 spccies studied can remove almost all phytoplankton cells larger than $10 \mu \mathrm{m}$ diameter. My data reveals that particle size is more important than absolute phytoplankton concentration in determining the rate at which copepods graze cells. Therefore not only the absolute food concentration but the size of the cells available serves to determine feeding thresholds. By reducing the removal rate of small cells sharply latep juveniles and adults do not deplete the main food of early juveniles.

In waters in which copepods have fed for up to $48 \mathrm{~h}$ measurements of phytuplankton abundance by electric particle counter differ from that determined by inverted microscope counts. This difference is not due to the presence of fecal pellets alone. To obtain reliable electronic data experiments should be run with few animals over short periods. Otherwise visual counts are necessary. Feeding data from electronic counts usually underestimate jeeding performance. 
Various questions arose from this study:

1. Why are small algae $(\leq 6 \mu \mathrm{m}$ ESD) grazed at much lower rates than larger ones $(\geq 10 \mu \mathrm{m}$ ESD)?

2. Are phytoplankton cells grazed at different rates than detritus particles of the same size and shape? Do chemosensors allow the copepod to discriminate particles? Donaghay and Small (1979) showed that diatoms, irrespective of their size, were eaten while plastic spheres were not. This strongly suggests a chemosensory behaviour, especially after Friedman and Strickler (1975) observed chemosensors on the mouthparts of calanoids.

3. At what level of food concentrations/compositions do different calanoids, especially subtropical species, start searching for food by migrating vertically? Is it at levels at which they can no longer fully meet their metabolic costs? How does searching differ for different copepodid stages? How do low phytoplankton levels affect the ingestion of detritus?

To understand the feeding behaviour and performance of entire copepod populations it is essential to offer the entire spectrum of sizes of food to developing cohorts of early. juveniles and allow them to develop to aduithood. This type of study is presently being conducted in our laboratory. 


\section{ACKNOWLEDGEMENTS}

This study was partly supported by National. Science Foundation Grants OCE76-01142 and OCE79-25055 and U.S. Department of Energy Contract EY-76-509-0936. Drs. K. Banse, R.P. Harris, D.W. Menzel and S.L. Smith comnented on the manuscript with constructive criticism. Support and advice are gratefully acknowledged. 


\section{FIGURE LEGENDS}

Figure 1. Eucalanus pileatus. Food concentrations over time as measured electronically (Coulter Counter TAII) and visually (inverted microscope). The diluted concentration after sample removal is shown by the lower of two symbols at the same time. When food concentrations reached very low levels one symbol was chosen as the difference between final and the following initial (diluted) food concentrations was very small.

Figure 2. Paracalanus sp. For legend see Figure 1.

Figure 3. Eucalanus pileatus. Volume swept clear per adult female per day over 48 hours measured electronically and visually. Symbols as in Figure 1.

Figure 4. Paracalanus sp. Volume swept clear per adult female per day over 48 hours measured electronically and visually.

Figure 5. Eucalanus pileatus CIV (large symbols) and Paracalanus sp. females (small symbols). Volume swept clear is presented for each 12 hour feeding period. The cell concentrations presented are from hours $0,12,24,36$ and 48 of each experiment, made with an inverted microscope.

Figure 6. Paracalanus Sp. Changes in grazing rates on $I$. pseudonana compared to changes in the relative amount of large algae (\% of total aigal volume).

Figure 7. Particle size spectra from near surface and near bottom of Onslow Bay, North Carolina. The total concentration amounts to $0.28 \mathrm{~mm}^{3} \cdot \ell^{-1}$. Modified after Paffenhöfer at al. (1980). 


\section{P.EFERENCES}

Adams, J.A., and Steele, J.h.: 1966. Shipboard experiments on the feeding of Calanus finmarchicus (Gunnerus). In: Some contemporary studies in Marine Science. H. Barnes ed., Allen and Unwin, London, pp. 19-35.

Bell, W. and Mitchell, R.: 1972. Chemotactic and growth responses of marine bacteria to algal extracellular products. Biol. Bull. 143: 265-277.

Corner, E.D.S., Head, R.N., and Kilvington, C.C.: 1972. On the nutrition and metabolism of zooplankton. VIII. The grazing of Biddulphia cells by Calanus helgolandicus, J. mar. Biol. Ass. U.K. 52: $347=861$.

Douaghy, P.L. and Smal1, L.T.: 1979. Food selection capabilities of the estuarine copepod Acartia clausij. Mar. Biol. 52: 137-146.

Friedman, M.M. and Strickler, J.R.: 1975. Chemorecption and feeding in calanoid copepods. Proc. Nat.. Acad. Sci. 72: 4185-4188.

Frost, B.W.: 1972. Effects of size and concentration of food particles on the feec ing behavior of the marine planktonic copepod Calanus pacificus Limnot. Oceanogr. 17: $805-815$.

Frost. B.W.: 1975. A threshold feeding behavior in Calanus pacificus. Limnol. Oceanogr. 20: 263-266.

Frost, B.W.: 1977. Feeding behavior of Calanus pacificus in mixtures of food parti. cles. Limnol. Ocfanogr. 22: 472-491.

Gamble, J.D.: 1978. Conepod grazing during a declining spring phytoplanktun bluon in the norther North Sea. Mar. Biol. 49: 303-315.

Harbison, G.K., and MCAlister, V.L.: 1980. Fact and artifact in copepod feeding experiments. Limnol. Oceanogr. 25: 971-981.

Ivịeva, I.V.: 1980. The dependance of crustacean respiration rate on body mass and habitat temperature. Int. Revue ges. Hydrobiol. 65: 1-47. 
Lam, R.K., and Frost, B.W.: 1976. Model of copepod filtering response to changes in size and concentration of food. Limnol. Oceanogr. 21: 490-500.

Landry, M.R.: 1976. The structure of marine ecosystems: An alternative. Mar. Biol. 35: 1-7.

Lee, R.F., Hirota, J., and Barnett, A.M.: 1971. Distribution and importance of wax esters in marine copepods and other zooplankton. Deep-Sea Res. 18: 1147-1165.

Mullin, M.M., and Brooks, E.R.: 1970. Growth and metabolism of two planktonic, marine copepods as influenced by temperature and type of food. In: Marine Food Chains, J.H. Steele, ed., 01 iver and Boyd, Edinburgh, pp. 74-95.

Paffentöfer, G.A.: 1980. Zooplankton distribution as related to summer hydrographic conditions in Onslow Bay, North Carolina. Bull. Mar. Sci. 30, 819-832.

Paffenhöfer, G.-A., Deibel, D., Atkinson, L.P., and Dunstan, W.M.: 1980. The relation of concentration and size distribution of suspended particulate matter to hydrography in Onslow Bay, North Carolina. Deep-Sea Res. 27A: 435-447.

Paffenhöfer, G.-A., and Knowles, S.C.: 1978. Feeding of marine planktonic copepods on mixed phytoplankton. Mar. Biol. 48: 143-152.

Parsons, T.R., LeBrasseur, R.J., Fulton, J.D., and Kennedy, P.D.: 1969. Production under the Fraser River Plume, February to May, 1967. J. Exp. Mar. Biol. ECOI. 3: $29-40$.

Poulet, S.A.: 1978. Comparison between five coexisting species of marine copepods feeding on naturally occurring particulate matter. Limnol. Oceanogr. 23: $1120-1143$.

Reeve, M.R., and walter, M.A.: 1977. Otservations on the existence of lower threshold and upper critical food concentrations for the copepod Acartia tonsa Dana. J. Exp. Mar. Biol. Ecol. 29: 211-221.

Richman, S., Heinle, D.R., and Huff, R.: 1977. Grazing by adult estuarine calanoid copepods of the Chesapeake Bay. Mar. Biol. 42: 69-84. 
Richman, S., Bohon, S.A., ani Robbins, S.E.: 1980. Grazing interactions among freshwater calanoid copepods. Am. Soc. Limnol. Oceanogr. Spec. Symp. 3. pp. $219-233$.

Roman, M.R. and Rublee, P.-A.: 1980. Containment effect in copepod grazing experiments: A plea to end the black box approach. Limnol. Oceanogr. 25: 982-990.

Steele, J.H.: 1974. The structure of marine ecosystems . Harvard University Press. Cambridge, ilass., $128 \mathrm{pp}$.

Tenore, K.R.: 1981. Organic nitrogen and caloric content of detritus. I. Utilization by the deposit-feeding polychaete Capitella capitata. Est. Coast. Mar. Sci. (in press).

Vidal, J.: 1980. Physioecology of zooplankton. IV,' Effects of phytoplankton concen tration, temperature, and body size on the net production efficiency of Calanus pacificus. Mar. Biol. 56. 203-211. 
TMBLE 1. INGESTION, ASSIMILATION AND METABOLIC EXPENDITURES OF CALANOID COPEPODS.

\begin{tabular}{|c|c|c|c|c|}
\hline SPECIES & $\begin{array}{l}\text { TEMPERATURE } \\
\left({ }^{\circ} \mathrm{C}\right)\end{array}$ & 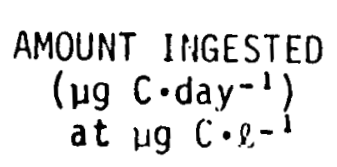 & $\begin{array}{l}\text { AMOUNT ASSIIILATED } \\
\left.\text { (ug } C \cdot d a y^{-1}\right)\end{array}$ & $\begin{array}{l}\text { AMOUNT RESPIRED } \\
\left(\text { ug } C \cdot \dot{d} a y^{-1}\right)\end{array}$ \\
\hline$\frac{\text { Calanus }}{\text { (Corner et ai. 1971) }}$ & 12.5 & $\begin{array}{c}24.4 \text { at } 37 \\
3.88 \text { at } 11\end{array}$ & $\begin{array}{l}8.54 \\
1.36\end{array}$ & $\begin{array}{c}4.2 \text { (Mull in and Brooks } \\
1970)\end{array}$ \\
\hline $\begin{array}{c}\text { Eucalanus pileatus female } \\
\text { June } 2-4,80 \frac{1}{h 24-36} \\
h 36-48\end{array}$ & $20^{\circ} \mathrm{C}$ & $\begin{array}{l}2.26 \text { at } 109 \\
1.01 \text { at } 103\end{array}$ & $\begin{array}{l}2.03 \\
0.91\end{array}$ & $\begin{array}{l}4.0 \text { (Ivleva 1980) } \\
\text { and } 2.3 \text { (Mullin } \\
\text { and Brooks 1970) }\end{array}$ \\
\hline 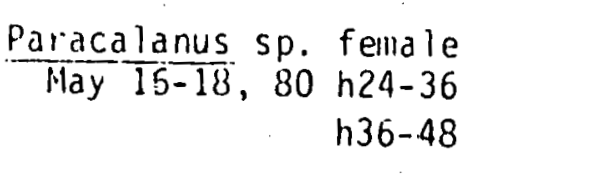 & $20^{\circ} \mathrm{C}$ & $\begin{array}{l}1.68 \text { at } 91 \\
1.07 \text { at } 60\end{array}$ & $\begin{array}{l}1.51 \\
0.96\end{array}$ & 1.03 (Ivleva 1980) \\
\hline
\end{tabular}


Figure 1

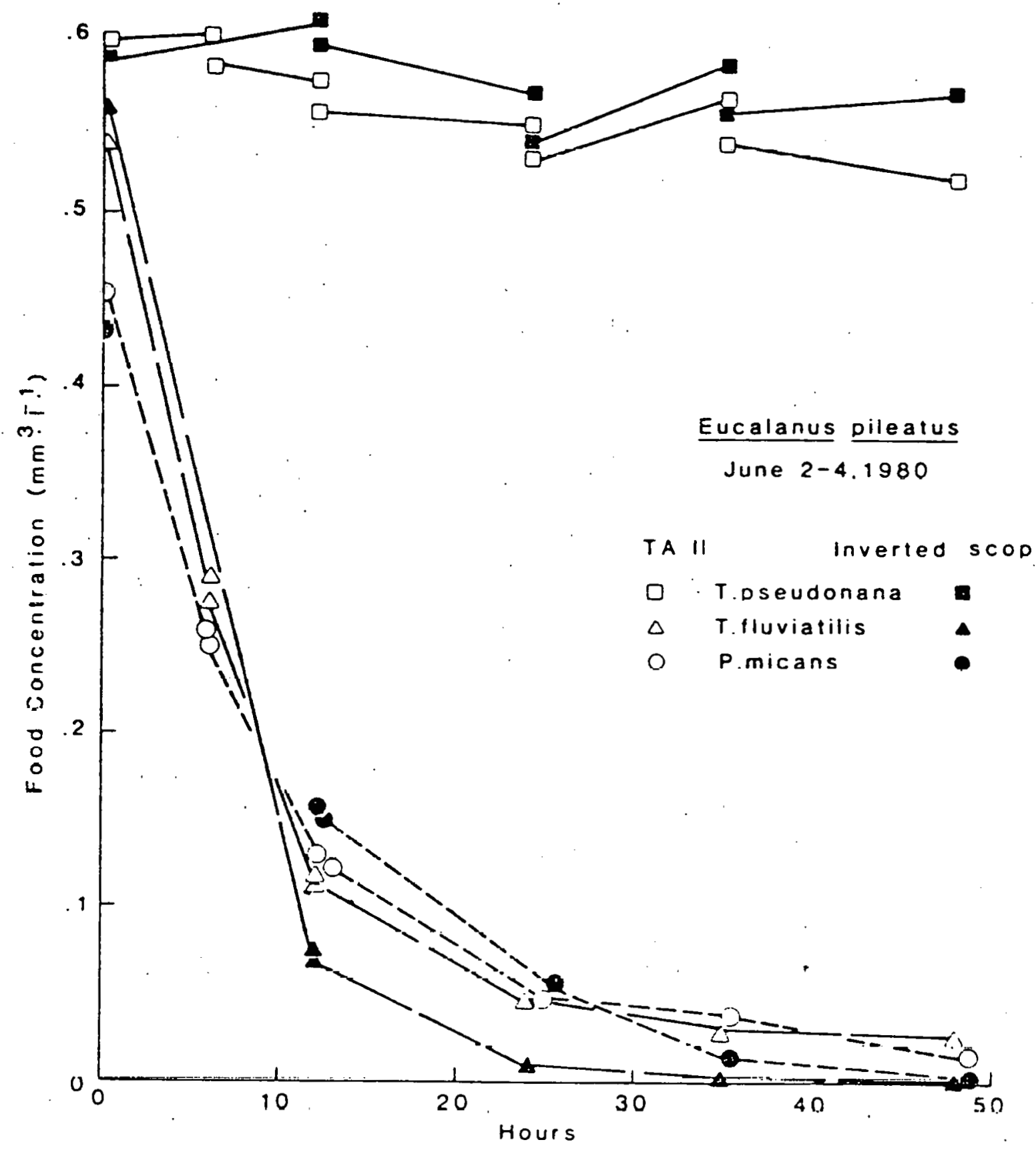




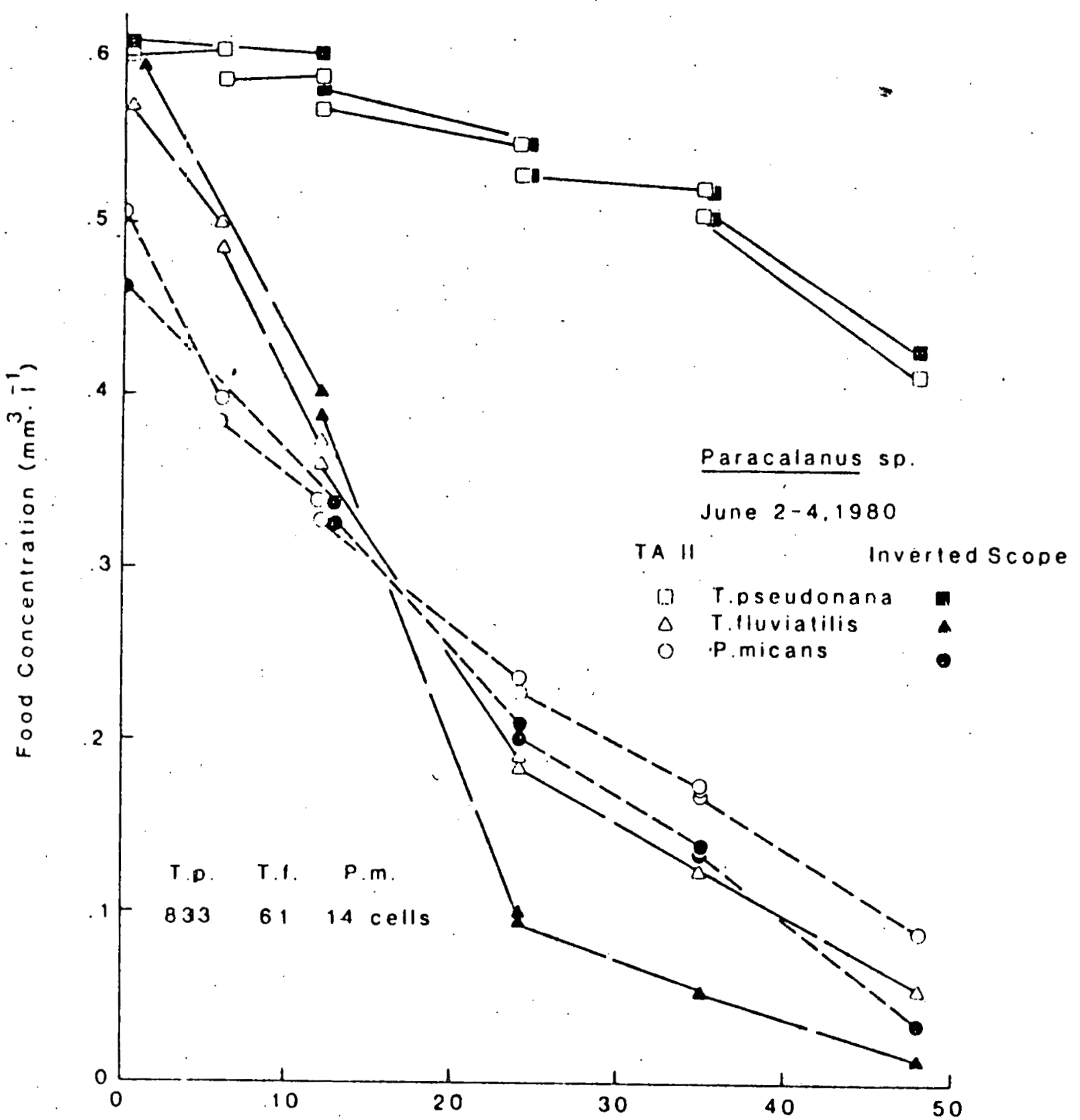


Figure 3

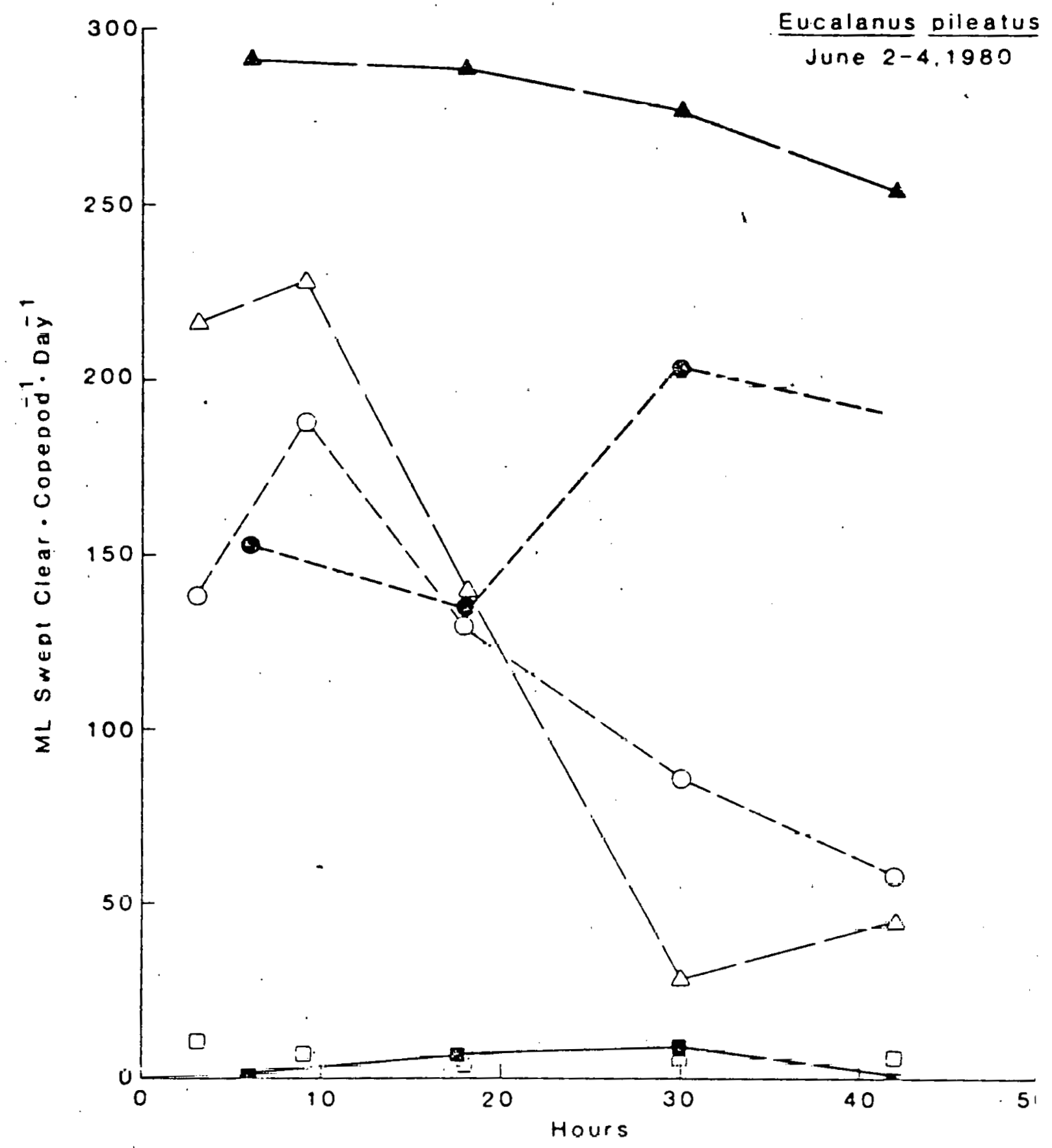


Paracalanus sp. June 2-4,1980
TA 11
Inverted scope
$\square \quad$ T.pseudonana
$\triangle$ Tifluviatilis
ว Pimicans

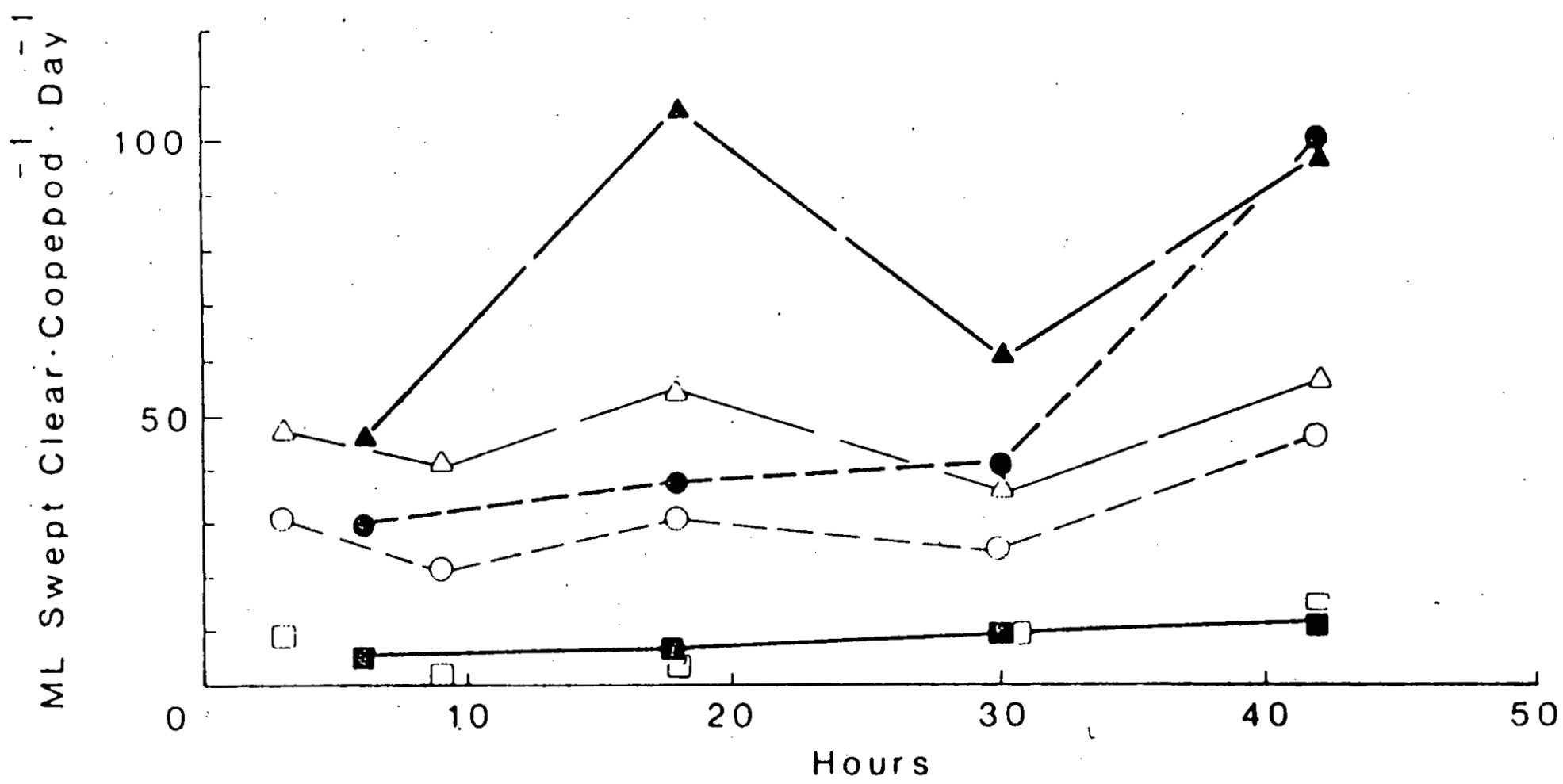




$$
\text { Cells } \mathrm{ml}^{-1}
$$

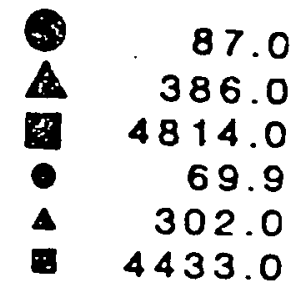

81.5
244.0
5161.0
37.8
93.6
4357.0

46.1
91.2
4695.0
7.0
12.4
4318.0

\section{8}

E.pileatus (May 25-27)

Paracalanue (May 16-18)

T.pseudunana

T.fluviatilis

P.micans

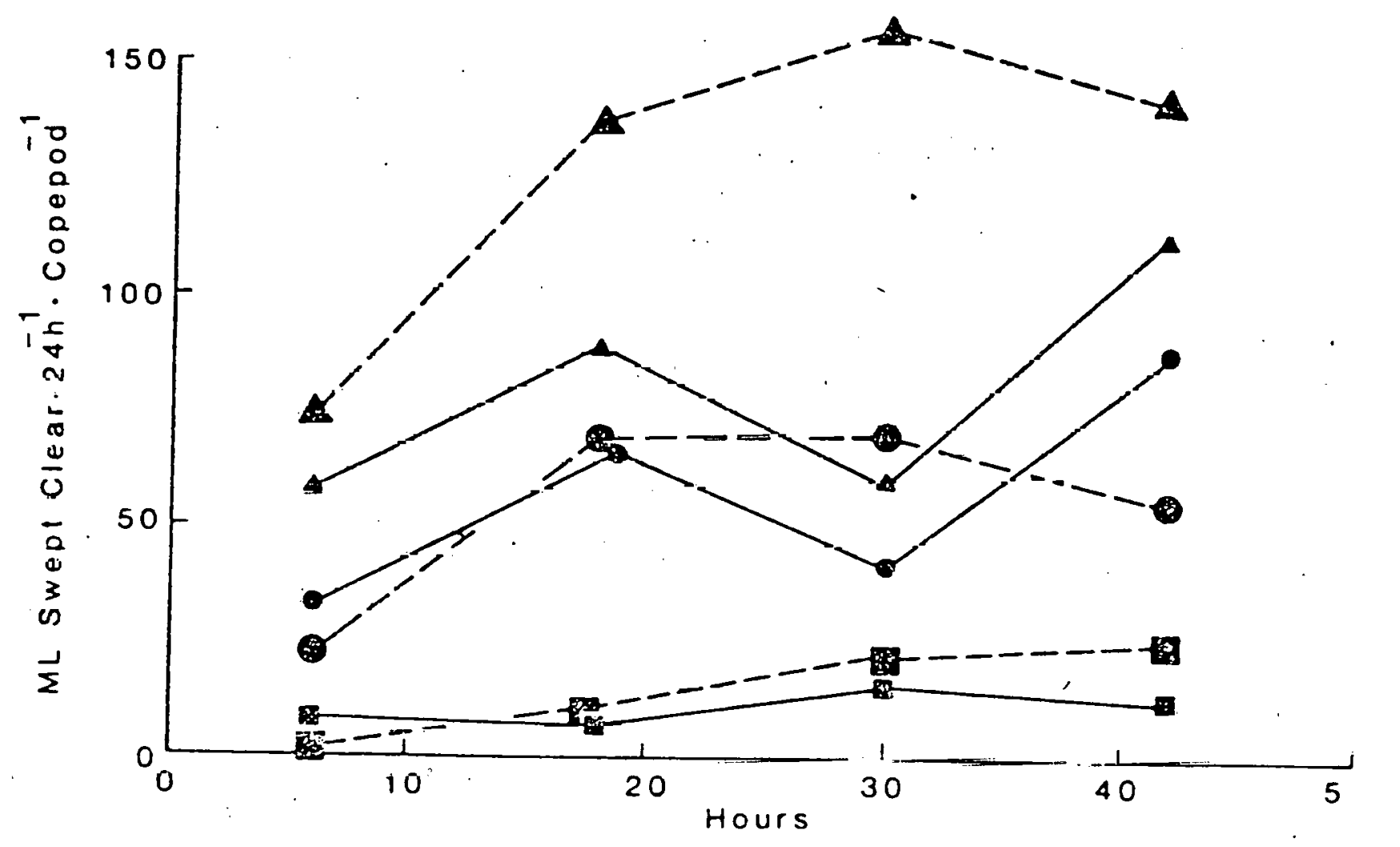


Figure 6

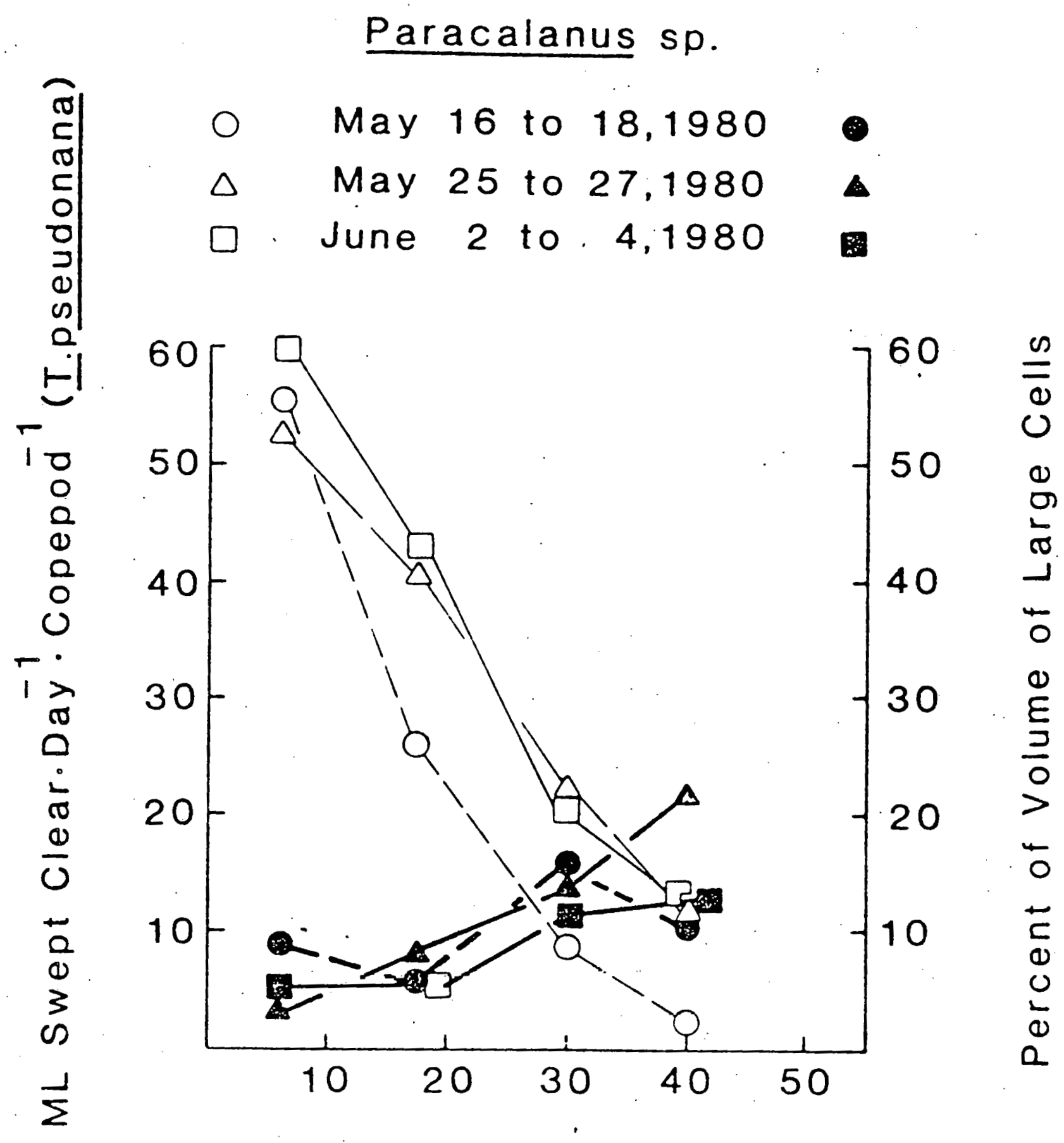

Hours 


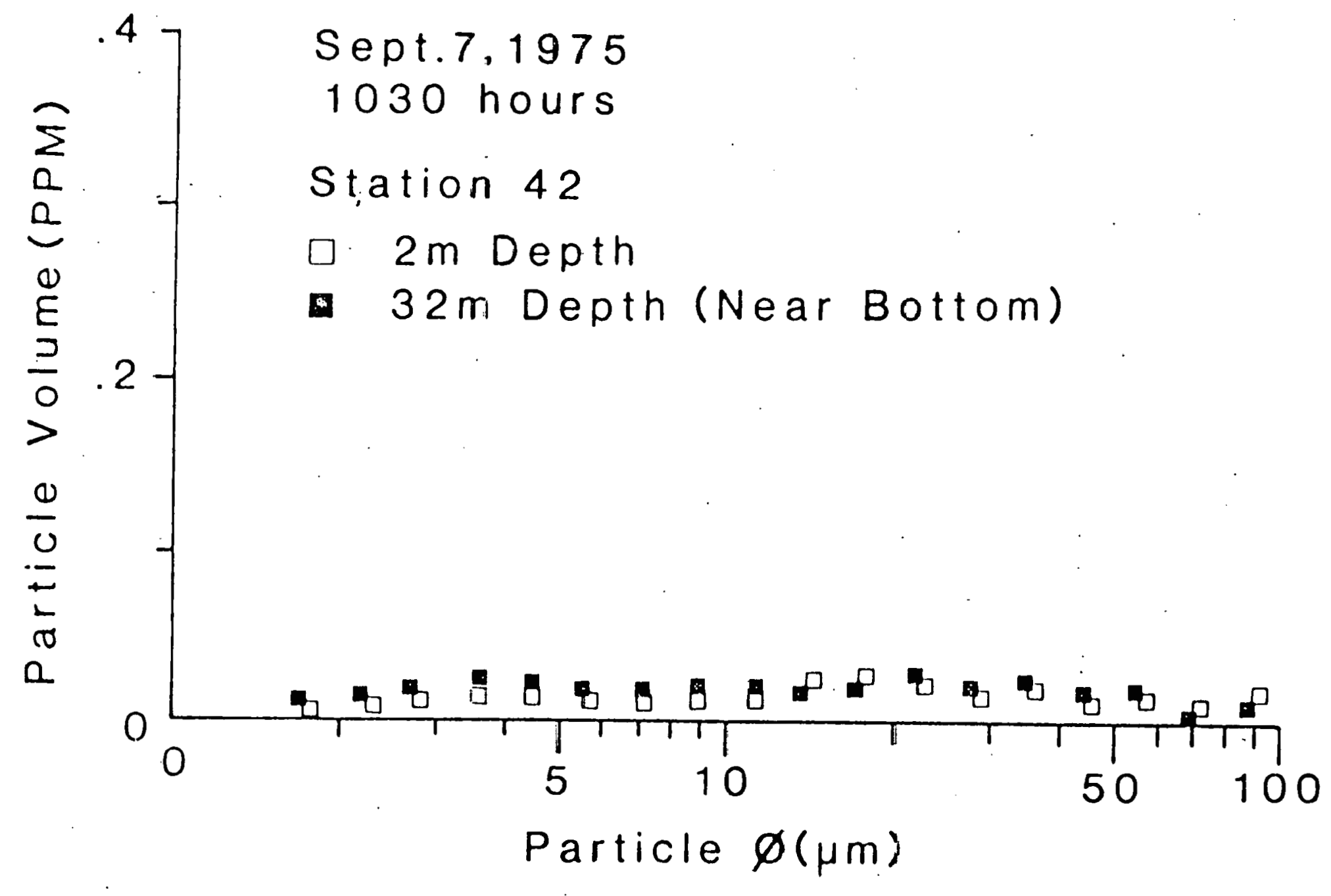

sept.7.1975

Station 42

- $2 \mathrm{~m} \mathrm{Depth}$

- 32 m Depth (Near Bottom)

Particle $\varnothing(\mu m)$ 
Grazing by Copepods in the Peru Upwelling

\section{Dear Editor:}

In the article "Grazing and excretion by zooplankton in the Peru upwelling system during April 1977" Dagg et al. (1980) calculated, from experimental data, the grazing impact of adult fenales of the 3 calanoid copepods Centropages brachiatus, Eucalanus inermis and Calanus chilensis on phytoplankton populations. Impact was considered small, which implied ingestion rates only 0.5 and $4.7 \%$ of : the daily primary production. From data on the abundance of small copepods the authors suggest a much greater impact by the total zooplankton population but do not estimate what this might be.

Dagg et al. calculated the grazing impact of adult (I assume females) Paracalanus denudatus assuming a body weight of $1.4 \mu \mathrm{g}$ carbon and an ingestion rate of $1.20 \mu \mathrm{gC} \cdot \mathrm{day}^{-1}$ at $1.0 \mathrm{PPM}\left(1.0 \mathrm{~mm}^{3} \cdot 1^{-1}\right)$ at $15^{\circ} \mathrm{S}$. However, concentrations as high as 1.0 PPM were not found on their transect. $\underline{P}$. denudatus adults were assumed to have removed on the average $8.0 \%$ of the daily primary production and the 3 large calanoids $2.9 \%$ resulting in a total of $10.9 \%$. This calculation takes into account only a small fraction of the abundant small copepods and bases grazing calculations on experiments conducted at particle concentrations of 1.0 PPM, about three times higher than the average found (Fig. 2 of Dagg et al. [1980]).

Here I calculate the daily ingestion rate of Paracalanus copepodids and adults (females) using the animal concentrations from Table 3 of Dago et al. 
(1980). Ingestion data were derived from feeding experiments conducted at $2 C$ with all copepodid stages and adult females of Paracalanus sp. (Paffenhöfer, unpublished). Shushkina et al. (1978) found that the surface temperature off Peru at $8^{\circ} \mathrm{S}$ increased from $16.5^{\circ} \mathrm{C}$ nearshore to $24.0^{\circ}$ offshore, making $20^{\circ} \mathrm{C}$ a reasonable comparison.

As Dagg et al. (1980) sampled with $102 \mathrm{um}$ mesh net all Paracalanus copepods except CI were probably sampied quantitatively (Paffenhöfer, unpublished results). One can expert that most Paracalanus collecled were younger copepodiu stages. Herte I assume that the average copepodid stage collected was CIII which weighs $0.72 \mu \mathrm{g}$ at $20^{\circ} \mathrm{C}$ (Paffenhöfer, unpublished). The average weight of adult females is $3.75 \mu \mathrm{Hg}$.

Ingestion data are taken from experiments which simulated early upwelling conditions, were conducted at an average particle concentration of $0.1 \mathrm{~mm}^{3} \cdot 1^{-1}$ each of mixed cultures of Isochrysis galbana $(4.5 \mathrm{\mu m}$ giameter), Thalassiosira fluviatilis ( $11 \mu \mathrm{m}$ width) and Rhizosolenia sp. (16 $\mu \mathrm{m}$ width, $350 \mu \mathrm{m}$ length). These algae, in order, contain 251,82 and $20 \mu \mathrm{g} \mathrm{C} \cdot \mathrm{mm}^{-3}$ of cell and cover the size range from 4 to 70 um equivalent spherical diameter. Three times $0.1 \mathrm{~mm}^{\hat{3}} \cdot 1^{-1}$ results in a total cell concentration of $0.3 \mathrm{~mm}^{3} \cdot 1^{-1}$ which is close to the avera!particle concentration found in the upper $100 \mathrm{~m}$ at $15^{\circ} \mathrm{S}$ (Fig. 2 of Dagg et al. 1980). It should be noted that the copepods in my experiments encountered relatively small amounts of detritus (their own fecal pellets) whereas in the experiments of Uagg et al. (1980) particulate matter from the ncean was used which probably had higher amounts of detritus. 
Table 1 shows ingestion rates for adults (females) and copepodids (CIII) per $\mathrm{m}^{3}$. In my experiments one adult female Paracalanus $\mathrm{sp}$. ingested 2.58 .1. $\mathrm{C}$ and one CIII $0.64 \mu \mathrm{g} \mathrm{C}$ daily. The total daily ingestion of Paracalanus is expressed as a percentage of the daily primary production at $15^{\circ} \mathrm{S}$; which was $1.15 \mathrm{~g} C \cdot \mathrm{m}^{-2} \cdot \mathrm{day}^{-1}$ or $11.5 \mathrm{mg} C \cdot \mathrm{m}^{-3} \cdot$ day $^{-1}$ (Barber et al., 1978). Calculated total ingestion rates range from $4.6 \%$ (Station 192) to $68.1 \%$ (Station 196) with an average of $32.7 \%$, almost three times the $10.9 \%$ calculated by Dagg et al. for the 3 larger calanoid adults and $\underline{\underline{p}}$. denudatus adults. On the average the females then graze $18.2 \%$ and the copepodids $14.5 \%$ of the daily primary production. If one also takes into account the abundance of the copepodids of the cyclopoids Oncaea and Oithona, and the nauplii of the small copepods which all pass $102 \mu m$ mesh, one could easily obtain total ingestion rates close to 100\% of the average daily productivity. Accurate calculations for cyclopoid copepodids have to wait as information on their ingestion, performance is scarce. However, it is obvious that small copepods, which have been largely ignored in most studies, can have a grazing impact on the available particulate matter well in excess of that of larger copepods.

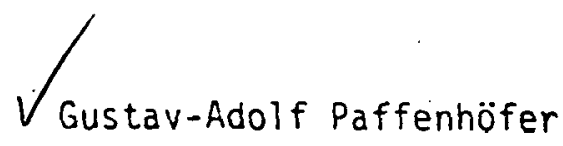

Skidaway Institute of Oceanography P.0. Box 13687 Savannah; Georgia 31406 U.S.A. 
TABLE 1. Ingestion rates of Paracalanus sp. (mg $\left.C \cdot d a y^{-1} \cdot \mathrm{m}^{-3}\right)$ at stations of a transect $15^{\circ} \mathrm{S}$ off Peru. Abundance values are given in Table 3 of Dagg
et al. (1980).

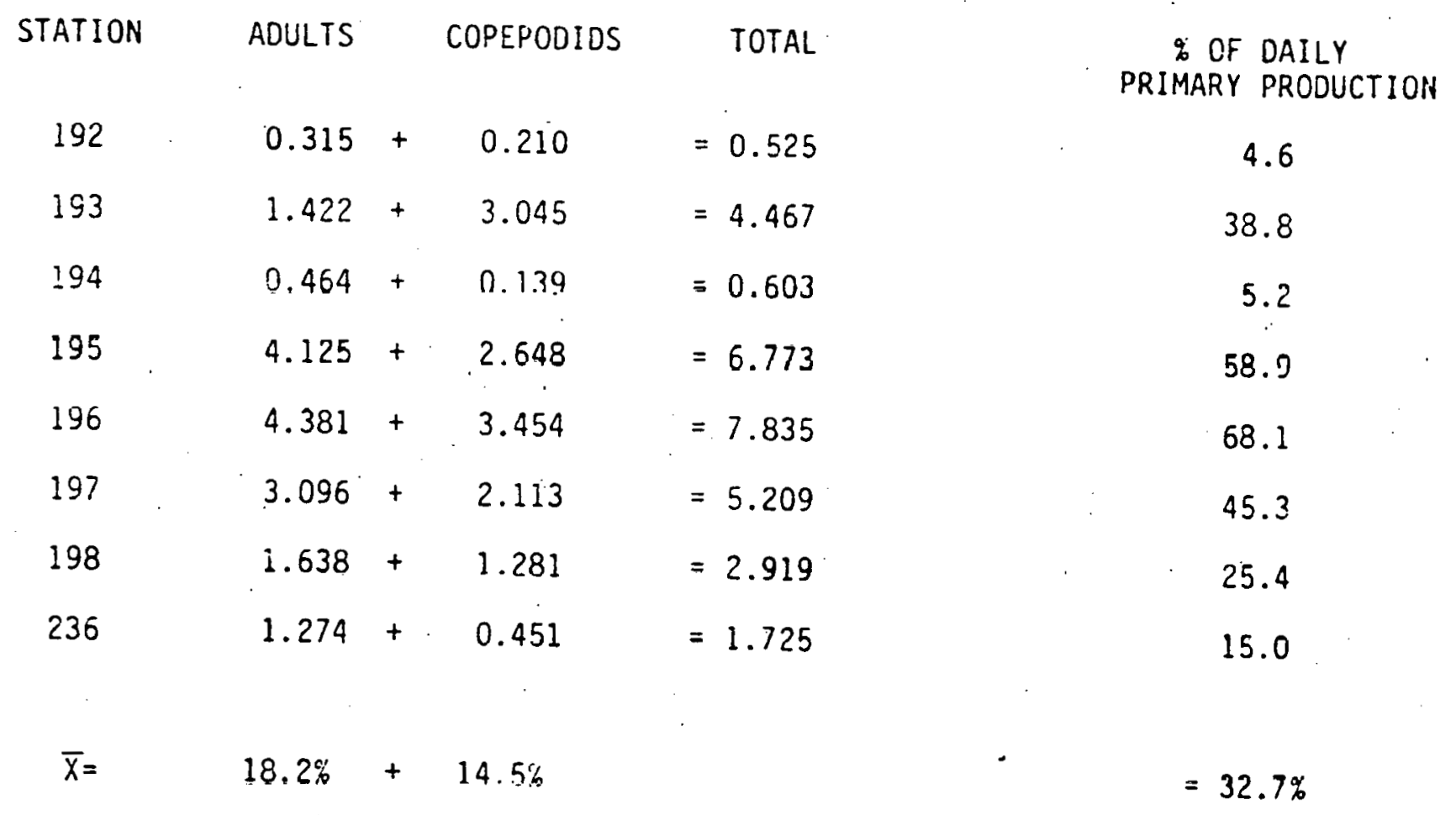




\section{LITERATURE CITED}

Barber, R.T., S.A. Huntsman, J.E. Kogelschatz, W.O. Smith, B.H. Jones and J.C. Paul, (1978). Carbon, chiorophyll and light extinction from Joint II 1976 and 1977. CUEA Data Report 49. 476 pp. (Unpubiished Document).

Dagg, M., T. Cowles, T. Whitledge, S. Smith, S. Howe and D. Judkins, (1978). Grazing and excretion by zooplankton in the Peru upwelling system during Apri] 1977. Deep-Sea Research 27A, 43-59.

Shushkina, E.A., M.Y. Vinogradov, Y.I. Sorokin, L.P. Lebedeva and V.N. Mikheyev, (1978). Functional characteristics of planktonic communities in the Peruvian upwelling region. Oceanology (USSR) $\underline{8}, 579-589$ (Engl. Transi.) 


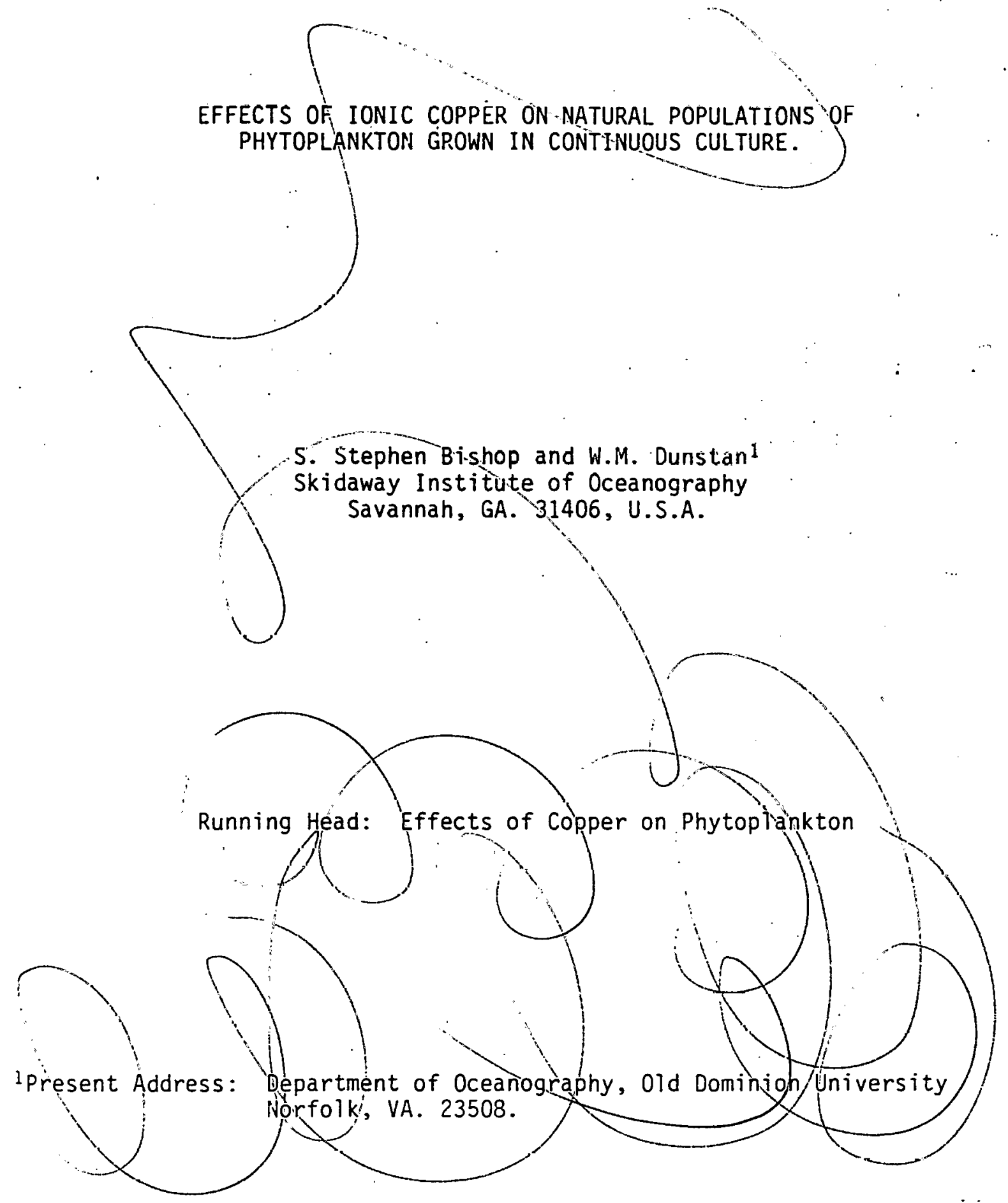


TABLE 11

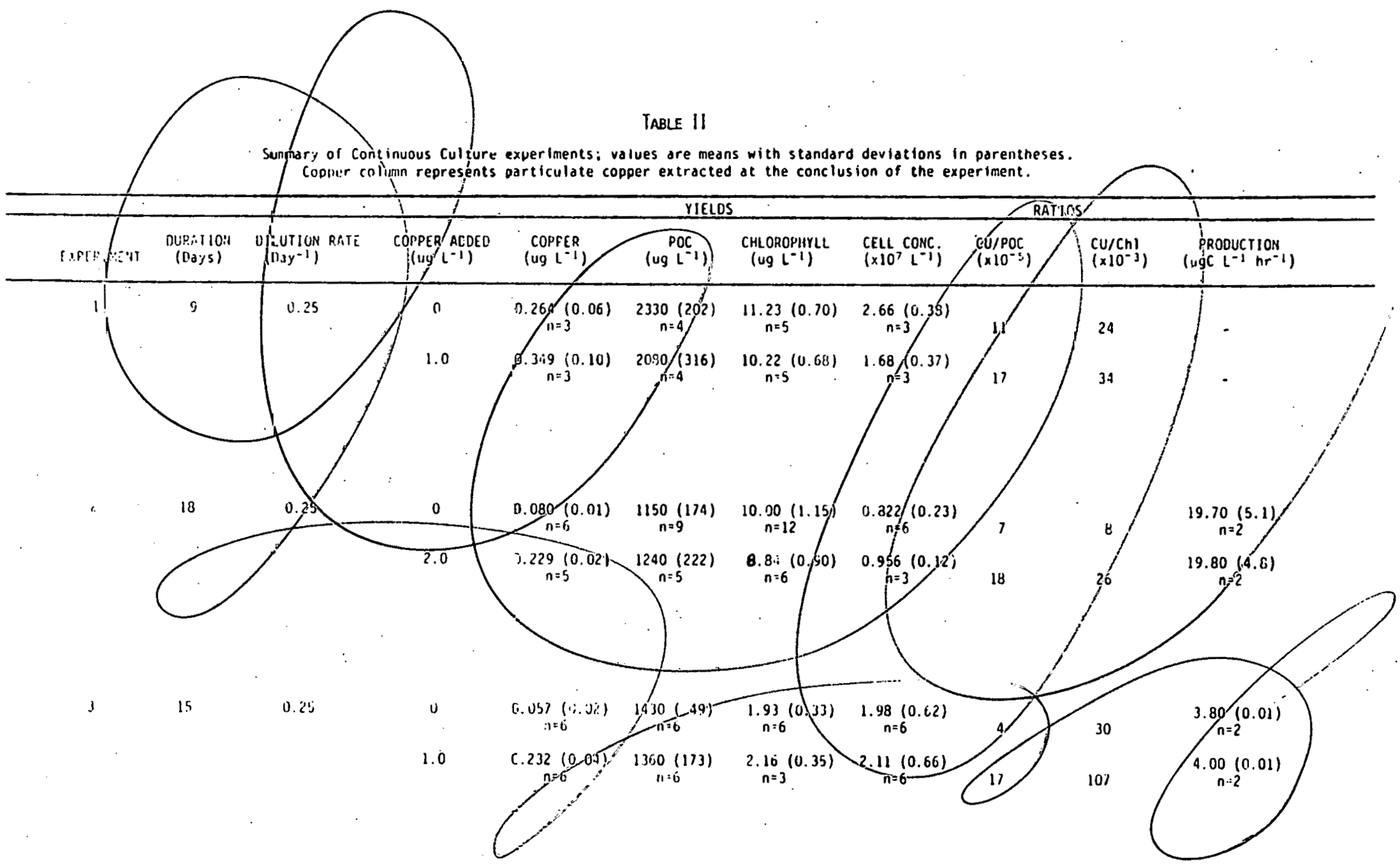


EFFECT OF UPWELLING ON PHYTOPLANKTON PRODUCTIVITY ON -THE OUTER SOUTHEASTERN U.S. CONTINENTAL SHELF

James $A$. Yoder ${ }^{1}$, Larry P. "Atkinson ${ }^{1}$, S. Stephen Bishop ${ }^{1}$,

Eileen E. Hofmann ${ }^{2}, 4$, Thomas N. Lee 3

'Skidaway Institute of Oceanography, Post Office Box 13687, Savannah, Georgia 31406, U.S.A.

${ }^{2}$ North Carolina State University, Department of Marine Science and Engineering, Post Office Box 5923, Raleigh, N. C. 27650, U.S.A.

3University of Miami, Rosentiel School of Marine and Atmospheric Science, 4600 Rickenbacker Causeway, Miami, Florida 33149, U.S.A.

4Present Address: Texas A \& M University, Department of Oceanography, College Station, Texas 77843, U.S.A. 


\section{ABSTRACT}

Gulf Stream frontal disturbances cause nutrient-rich waters to frequently upwell and intrude onto the southeastern U.S. continental shelf between Cape Canaveral, Florida and Cape Hatteras, North Carolina. Phytoplankton response in upwelled waters was determined with three interdisciplinary studies conducted during April, 1979 and 1980 and in summer, 1978. The results show that when shelf waters are not stratified, upwelling causes productive phytoplankton (diatom) blooms on the outer shelf. Phytoplankton production averages about $2 \mathrm{~g} \mathrm{C} \mathrm{m}^{-2} \mathrm{~d}^{-1}$ during upwelling events, and "new" production is 50\%, or more, of the total. When shelf waters are stratified, upwelled waters penetrate well onto the shelf as a subsurface intrusion in which phytoplankton production averages about $5 \times$ higher than the nutrient-depleted overlying mixed layer. Phytoplankton within the intrusion deplete upwelled $\mathrm{NO}_{3}$ in about 7-10 days at which point no further net increase in phytoplankton biomass occurs.

Current meter records show that upwelling occurs roughly $50 \%$ of the time on the outer shelf during November-April (shelf not stratified), and we estimate that seasonal primary production in upwelled waters is $175 \mathrm{~g} \mathrm{C} \mathrm{m}^{-2} 6$ mos-1 of which at least $50 \%$ is "new" production. More than $90 \%$ of outer shelf primary and "new" production occurs during upwelling, and thus upwelling is the dominant process affecting primary productivity of the outer shelf. Our seasonal estimates of outer shelf primary and "new" production are, respectively, $2 \times$ and $10 x$ higher than previous estimates that did not account for upwelling. 


\section{INTRODUCTION}

Circulation on the outer southeast U.S. continental shelf is directly and frequently affected by Gulf Stream frontal processes. The cyclonic front generally follows the shelf break from: Miami, Florida to Cape Hatteras, North Carolina, a distance of more than $1000 \mathrm{~km}$. The front is disturbed by wave-like meanders and eddies which occur every several days to two weeks, have alongand cross-shelf dimensions greater than $100 \mathrm{~km}$ and $20 \mathrm{~km}$, respectively, and propagate along the front from south to north at average speeds of approximately $35 \mathrm{~km} \mathrm{~d}$ (Webster, 1961; Lee, 1975; Lee and Mayer, 1977; Pietrafesa and Janowitz, 1979; Lee and Brooks, 1979; Vukovich, Crissman, Bushnell and King, 1979; Blanton, Atkinson, Pietrafesa and Lee, 1981; Lee, Atkinson and Legeckis, 1981 ). Physical and hydrographic characteristics of eddies along the cyclonic Gulf Stream front off the southeast U.S. coast were described with satellite IR images (Vukovich et al., 1979), current meters (Lee and Brooks, 1979; Pietrafesa and Janowitz, 1979), shipboard hydrographic observations (Atkinson, 1978), and by integrating all three types of measurements (Lee et al., 1981). All investigators agree (so far) that frontal eddies are common features; the "disturbance" propagates northward along the front; eddies cause upwelling and intrusion of upwelled waters onto the shelf; and they are a primary cause of subtidal frequency current fluctuations on the outer shelf. The investigators disagree on the appropriate name for the features (shingles, fi]aments, spin-nff eddies aro, or were, used), the clrculation within the "warm tongue" (compare Chew, 1981 with Lee et al., 1981), and whether upwelled waters are removed from a fixed position on the outer shelf primarily by downwelling off the shelf (Pietrefesa, personal communication) or by northward advection (Lee et al., 1981). Of the issues in dispute the latter has the most important biological implication because it affects the calculation of shelf residence time for upwelled waters, and 
because it will determine where some of the biological production within upwelled waters eventually will go. However, all investigators agree that eddies induce upwelling and from a phytoplankters perspective, this is the "first order" effect and the one we consider in this manuscript.

Upwelling source water is a mixture of water masses dominated by Western North Atlantic Water (also referred to as North Atlantic Central Water) but can also include continental edge water, Gulf Stream surface water, Subtropical Underwater and Antarctic Intermediate Water. Hereafter, we will refer to upwelled water as Gulf Stream Water (GSW) to distinguish it from shelf water. An important and useful characteristic of. GSW is that $\mathrm{NO}_{3}$ is linearly related to temperature below about $21^{\circ} \mathrm{C}$. In general, the temperature of freshly upwelled GSW found on the southeastern continental shelf ranges from about 15 to $22^{\circ} \mathrm{C}$ which corresponds to about 15 and $\mathrm{O}_{\mu \mathrm{M} \mathrm{NO}}$, respectively. Upwelled $\mathrm{NO}_{3}$ is virtually the only important source of "new" nitrogen for the outer shelf (Lee et al., 1981); since resident shelf waters contain negligable amounts of inorganic nitrogen, and river inputs are important only to the inner sheif (Dunstan and Atkinson, 1976; Bishop, Yoder and Paffenhöfer, 1980; Yoder, Atkinson, Blanton, Deibel, Menzel and Paffenhöfer, 1981).

Before the effects of upwelling were known, outer shelf primary production was believed to be relatively low - ca. $130 \mathrm{~g} \mathrm{C} \mathrm{m}^{-2} \mathrm{y}^{-1}$ (Haines and Dunstan, 1975). Because the importance of offshore nutrient sources was not recognized at the time, Haines (1974) concluded that recycling within the water column provided more than $95 \%$ of the nitrogen required to support primary production on the outer shelf. Dthers (Turner, Woo and Jitts, 1979;. Turner, 1981) concluded that outer and inner shelf plankton dynamics were closely coupled and implied that outwelling of nutrients from estuaries and marshes controlled plankton productivity across the shelf. 
Recent studies of upwelling and its effect on biological processes of the southeastern shelf led to a different view of outer shelf plankton productivity and the processes responsible for it (Dunstan and Atkinson, 1976; Atkinson, Paffenhöfer and Dunstan, 1978; Bishop et al., 1980; Hofmann, Pietrafesa, Klinck and Atkinson, 1980; Paffenhöfer, 1980; Paffenhöfer, Deibel, Atkinson and Dunstan, 1980; Yoder et al., 1981A; Yoder, Atkinson, Lee, Kim and McClain, 1981B). Briefly, these studies show that chlorophyll a within upwelled waters is roughly $10 \times$ higher than observed when there is no upwelling (ca. 5 versus $0.5 \mathrm{mg} \mathrm{m}^{-3}$ ), primary production may be several times higher during upwelling than under non-upwelling conditions, large phytoplankton (diatom) patches (ca. $1000 \mathrm{~km}^{2}$ ) form on the outer shelf within upwelled waters, chlorophyll a concentrations are often higher within subsurface intrusions of GSW than in the overlying mixed layer, higher numbers of zooplankton are found within upwelled waters than in resident shelf waters and finally, the biological response to upwelling is more pronounced at the outer shelf than at the middle or inner shelf. Based primarily on the cross-shelf distribution of chlorophyll a and nutrients, Bishop et al. (1980) proposed that the southeastern continental shelf could be roughly divided into three zones of approximately equal width $(40 \mathrm{~km})$ off the Georgia coast: the outer, middle, and inner shelf. Phytoplankton dynamics of the outer shelf (ca. 40-200 m isobaths) are controlled by periodic inputs of offshore nutrients, whereas inner shelf (0-20 $\mathrm{m}$ isobaths) production is primarily affected by river and estuarine outwelling. Production on the middle shelf ultimately depends on nutrients that cross either of the other two zones.

Results presented to date (references above) were primarily descriptions of biological distributions (e.g., chlorophyll a, phytoplankton and zooplankton numbers), and the conclusions were limited to what these distributions imply to productivity. Among the conclusions (generally presented as hypotheses) were 
that: (1) upwelling is the most important process controlling phytoplankton productivity of the outer shelf, (2) outer shelf productivity is higher than originally believed, (3) a relatively high percentage of primary production is "new" production (in sensu .Dugdale and-Goering, 1967)., (4) a significant percentage of primary production in the water column occurs below the mixed layer, and (5) episodic upwelling causes frequent highly productive short-lived phytoplankton blooms that occur throughout the year. The purpose of this paper is to address the above hypotheses primarily using phytoplankton "rate measurements" (e.g., $\mathrm{C}$ and $\mathrm{NO}_{3}$ uptake), or when appropriate, to infer rates from temporal changes in phytoplankton biomass. We describe the response of phytoplankton to individual. upwelling events and estimate the importance of upwelling to seasonal outer shelf primary and "new" production.

\section{METHODS}

Figure 1 shows the continental shelf off the South Carolina, Georgia, and north Florida coasts (hereafter referred to as the Southeastern Shelf) and locations where our studies were conducted. Cruises were during April (spring) and July/August (summer) of 1978, 1979, and 1980 using the R.V. Bluefin, Eastward, Gilliss, or Iselin. A different sampling strategy was used in the spring and summer. During spring, shelf waters are $5-10^{\circ} \mathrm{C}$ colder than Gulf Stream surface waters making it possible to use satellite thermal imagery to locate frontal eddies prior to, and during the cruises (see Lee et al., 1981; Yoder et al., 1981B). In addition, upwelled waters are generally restricted to the shelf break and do not penetrate more than 20-40 km onto the shelf (see Atkinson, 1977; Lee et al., 1981; Yoder et al., 1981B). To determine the spatial scales of upwelling features, surface and subsurface hydrography of upwelled waters were mapped using a thermosalinograph and XBTs, and surface chlorophyll was determined by underway measurements of in vivo fluorescence (see Lee et al., 1981; Yoder et al., 1981B). 
During summer, shelf waters are stratified and upwelled GSW moves onto the shelf as subsurface intrusions, and differences in surface temperature between shelf and Gulf Stream waters are slight. Under these conditions satellite imagery is not useful for detecting upwelled waters...However, the temperature of resident shelf surface water in summer is about $28^{\circ} \mathrm{C}$, and subsurface intrusions of upwelled waters (ca. 15-22 C) can be. located with. XBTs or by towing a temperature probe at a depth of $20-40 \mathrm{~m}$.

Water samples were generally collected with a General Oceanics rosette sampler attached to a Plessy CTD. When the rosette was not available water was collected with Niskin bottles after first determining the vertical temperature structure with an XBT. In the latter case salinity of discrete samples was determined with a Plessy Model $6230 \mathrm{~N}$ salinometer. During spring, both temperature and salinity characteristics were required to identify upwelled waters, since the temperature of upwelled GSW and shelf water is often the same. However, the T-S characteristics of GSW distinguish it from shelf waters (e.g., Lee et al., 1981).

The CTD was calibrated using procedures described by Chandler et al. (1978). Current meter data were processed according to Lee et al. (1981). Nutrients were determined with a Technicon AutoAnalyzer (Glibert and Loder, 1977). In general, $\mathrm{NO}_{2}$ was not determined separately from $\mathrm{NO}_{3}$ but has never been found to be a significant component of $\mathrm{NO}_{3}+\mathrm{NO}_{2}$ in upwelled GSW. Hereafter, we refer to $\mathrm{NO}_{2}+\mathrm{NO}_{3}$ as $\mathrm{NO}_{3}$. Sumples not immediately analyzed were frozen. Vertical profiles of subsurface irradiance were obtained with a LI-COR spherical quantum sensor. Incident irradiance was continuously monitored during simulated in situ. productivity experiments with LI-COR quantum sensor, model LI-190S, equipped with a LI-COR integrator, model LI-550. Lugols solution was used to preserve phytoplankton for later identification and enumeration. An inverted microscope was 
used to identify and count the samples.

For the analyses and experiments described below, water samples were first filtered through $183 \mu \mathrm{m} \mathrm{Nitex} \mathrm{netting} \mathrm{to} \mathrm{remove} \mathrm{the} \mathrm{larger} \mathrm{zooplankton.} \mathrm{Nets}$ with a smaller mean pore size were not used to avoid excluding larger phytoplankton cells and colanies. Chlorophyll a and phaeopigment $\underline{a}$ were determined using the fluorometric method of Yentsch and Menzel (1963) as described by Strickland and Parsons (1972). For particulate C and N measurements, a known volume of water (0.5 - 1 liter) was filtered onto $25 \mathrm{~mm}$ pre-combusted Gelman type A/E glass fiber filters, the filters were frozen; then freeze-dried, and analyzed for $\mathrm{C}$ and $\mathrm{N}$ content with a Perkin-Elmer Elemental Analyzer. Particulate Si was determined using the filter method of Paasche (1980).

Primary production ( $C$ uptake) was determined using the ${ }^{14} \mathrm{C}$-labelled sodium bicarbonate method (Steemann Nielsen, 1952). Five ucuries of ${ }^{14} \mathrm{CO}_{2}$ were added to $125 \mathrm{ml}$ flasks (2 light and 1 dark) containing prescreened water samples as described above. After incubation the contents were filtered through $0.45 \mu \mathrm{m}$, $25 \mathrm{~mm}$ Millipore HA filter disks. Filters were dried in a dessicator, fumed with $\mathrm{HCl}$ to remove labelled "inorganic" carbon, and ${ }^{14} \mathrm{C}$ activity was determined with a Beckman liquid. scintillation counter using New England Nuclear's "Omnifluor" cocktail (98\% PPO, $2 \%$ Bis-MSB).

$\mathrm{NO}_{3}$ uptake was determined using the stable isotope method $\left(15 \mathrm{NO}_{3}\right)$ of Dugdale and Goering (1967). The added label usually did not increase the total $\mathrm{NO}_{3}$ concentration by more than 10-20\%. However, because at least 0.2 umoles $\mathrm{NO}_{3} \mathrm{liter}^{-1}$ was added, the total $\mathrm{NO}_{3}$ concentration was occasionally increased by as much as a factor of 2. During summer 1978, 4 liter glass bottles were used for $\mathrm{NO}_{3}$ uptake experiments. After incubation, the contents were filtered onto $47 \mathrm{~mm}$ pre-combusted type A/E Gelman glass fiber filters. The filters were then frozen and eventually freeze-dried. In 1979 and 1980, 1 liter glass bottles were used and after 
incubation, the contents were filtered onto $25 \mathrm{~mm}$ pre-combusted type $A / E$ Gelman glass fiber filters. The isotope ratios of 1979 and 1980 samples were determined by Or. Hans Paerl, University of North Carolina Harine Institute, using model NTA-1 Jasco emmission spectrometer. The rate of $\mathrm{NO}_{3}-\mathrm{N}$ uptake was calculated using equation 1.

$$
\mathrm{NO}_{3}-\mathrm{N} \text { uptake }\left(m g N m^{-3} h^{-1}\right)=\left[P N\left(N_{p}-N_{b}\right) /\left(N_{s}-N_{p}\right)\right] / t
$$

where, $P N=$ particulate $\mathrm{N}\left(\mathrm{mg} \mathrm{N} \mathrm{m}^{-3}\right)$

$N_{p}=\% 1{ }^{15} \mathrm{~N}$ on the filter

$N_{0}=$ natural $15 \mathrm{~N}$ abundance $(\%)$

$N_{S}=\% 15 N_{3}-N$ in seawater after enrichment

$t=$ incubation time $(h)$

Several different procedures were used to incubate samples for carbon and $\mathrm{NO}_{3}$ uptake experiments. Because intruded waters were often up to $10^{\circ} \mathrm{C}$ colder than the surface mixed layer in summer, surface water could not be used to maintain temperature control during incubations of samples from these waters. Instead, water collected from intruded waters was incubated at 1 or more irradiance levels in temperature controlled "laboratory" incubators using Sylvania "Plant Light" as the light source. For spring cruises, bottles were incubated under simulated in situ conditions. The bottles were placed in bags constructed of different numbers of layers of plastic screen to simulate incident irradiance at the depth which water was collected. The bottles were incubated "on deck" within tanks through which surface water was continously pumped. In 1980, better temperature control was obtained using 2 plexiglass tanks which were kept at 2 different temperatures with Forma Scientific "Masterline" cooling and heating units.

In 1978, the incubation time for both primary production and $\mathrm{NO}_{3}$ uptake experiments was 4 hours. In spring 1979, 4 and 24 hour incubations were used. The 4 hour results agreed within about 20\% with those from the $24 \mathrm{~h}$ after the 4 hour rates were converted to daily rates using a factor based on the ratio of 
light received during 24 hours to that received during the shorter incubation. In 1980, all incubations were for 24 hours.

In summer, 1978, a drogue designed by Dr. G. -A. Paffenhöfer was followed and used as a reference station. The drogue sail was a plastic sheet wrapped around aluminum hoops to form a cylinder (diameter $=1 \mathrm{~m}$, height $=2 \mathrm{~m}$ ) open at each end.

\section{RESULTS}

APRIL, 1979

\section{Physical Description}

The only current record for the April, 1979 study was from shelf break (75 m isobath) and mid-shelf ( $30 \mathrm{~m}$ isobath) moorings located about $90 \mathrm{~km}$ north of the area sampled by the ship (see Fig. 1). Assuming the average propagation velocity of $35 \mathrm{~km} \mathrm{~d}^{-1}$, the shelf break mooring detected Gulf Stream disturbances about 3 days after they affected the area where biological and hydrographic observations were made. The current and temperature record at the shelf break mooring showed that two large frontal eddies moved past the morring in rapid succession between 15-27 April, and a smaller one reached the mooring on 30 April. All three eddies were also observed with satellite IR imagery (Lee, unpublished; C. R. McClain, personal communication) and the last two by shipboard measurements. Shipboard sampling on 20-22 April determined temperature, salinity, nutrient, and chlorophyll structures of the southerly part of the second of the two large eddies. These results showed that a large phytoplankton patch was present within upwelled waters that formed the cold core of the frontal eddy (Yoder et al., 1981B). The patch was more or less elliptically shaped having an alongshelf dimension of approximately $100 \mathrm{~km}$ and maximum width of $40 \mathrm{~km}$.

Figure 2 shows that winds were very strong (ca. $20 \mathrm{~m} \mathrm{~s}^{-1}$ ) from 24 to 27 April and were upwelling-favorable on 26-27 April.. However, the current and 
temperature record at the shelf break mooring $90 \mathrm{~km}$ to the north of the study area did not indicate any significant wind driven upwelling. On 26 and 27 April, shelf break currents rotated counter-clockwise from southward to northward flow which was coherent with increasing temperatures throughout the water column. This signature indicates northward passage of the southern extremity of the second of the large frontal eddies (see Lee et al., 1981 for description of eddy current signatures). However, the strong winds probably had a biologically important effect by mixing nutrients upwelled by the frontal eddies farther up into the euphotic zone.

Hydrographic time series at the $45 \mathrm{~m}$ and $75 \mathrm{~m}$ isobath are shown in Figure 3. These two locations were $5 \mathrm{~km}$ apart and all primary production stations were between, or at, these two locations... Salinity was always greater than $36 \times 10^{-3}$ and is not shown. Note the position of the $20^{\circ} \mathrm{C}$ isotherm. At both stations this isotherm is always above $40 \mathrm{~m}$ and is occasionally above $15 \mathrm{~m}$. In the absence of upwelling, the $20^{\circ} \mathrm{C}$ isotherm is close to $100 \mathrm{~m}$ at the shelf break during April (e.g., Atkinson, 1978). At the $75 \mathrm{~m}$ isobath, changes in the depth of isotherms colder than about $18^{\circ} \mathrm{C}$ reflect the northward passage of the second of the two large frontal eddies (22-24 Apri1) and the presence and passage of the third (and smaller) eddy (24-30 Apri1). Changes in the depth of isotherms warmer than about $20^{\circ} \mathrm{C}$ were influenced by the strong winds between 24-27 April. Surface waters at both stations were about $1^{\circ} \mathrm{C}$ cooler during this 3 day period than at other times in the record which suggests strong vertical mixing in the upper portion of the water column.

\section{Biological Effects}

Figure 4 shows the vertical distributions of density, $\mathrm{NO}_{3}$, chlorophyll $\underline{a}$, and the rates of $\mathrm{C}$ and $\mathrm{NO}_{3}-\mathrm{N}$ uptake at shelf break stations occupied in April, 1979. All production stations were at, or between, the two locations $(5 \mathrm{~km}$ 
apart) where we showed the hydrographic time series (see Figure 3). At all stations, the upper 50 meters was strongly stratified with a density gradient of at least one sigma-t unit through the pycnocline. The base of the euphotic zone ( $1 \%$ isolume) extended to a depth of $30-45 \mathrm{~m}$, whereas the pycnocline started no deeper than $25 \mathrm{~m}$. Thus, the euphotic zone always extended into the pycnocline. The pycnocline separated a $\mathrm{NO}_{3}$-depleted surface mixed layer from $\mathrm{NO}_{3}$-rich GSW below it. The average chlorophyll a concentration in the mixed layer was $1.5 \mathrm{mg} \mathrm{m}^{-3}$, and primary production exceeded $5 \mathrm{mg} \mathrm{C} \mathrm{m}^{-3} \mathrm{~h}^{-1}$ in the mixed layer at 4 of 6 stations. Maximum $C$ assimilation numbers in the mixed layer at each station ranged from $15-19 \mathrm{mg} \mathrm{C} \cdot \mathrm{mg} \mathrm{Chl} \underline{a}^{-1} \mathrm{~h}^{-1}$. $\mathrm{NO}_{3}$ uptake measurements were not obtained in the surface mixed layer, but the vertical distribution of $\mathrm{C}$ and $\mathrm{NO}_{3}-\mathrm{N}$ uptake were similar below the mixed layer at 3 of 4 stations.

A time series of euphotic zone integrals of $\mathrm{NO}_{3}$, chlorophyll $\underline{\text { a }}$, primary production, and other measurements are presented in Figure 5 . Because all primary production stations were within $5 \mathrm{~km}$ of each other, the results are merged into one time series. Euphotic zone $\mathrm{NO}_{3}$ and chlorophyll a showed 2 peaks (Fig. 5). The chlorophyll a peak lagged $\mathrm{NO}_{3}$ by about 1 day. Temporal changes in primary production tracked chlorophyll a. The first peak in euphotic $\mathrm{NO}_{3}$ (resulting from upwelling associated with the second large frontal eddy) was observed on 22 April. The decrease in euphotic zone $\mathrm{NO}_{3}$ from 22-24 April was probably caused by a combination of phytoplankton uptake and either downwelling or advection of nutrient-rich water as the frontal eddy passed through this area. Because C assimilation numbers increased slightly from 23 to 24 April, the decrease in primary production was solely a result of lower euphotic zone chlorophyll a rather than a decline in the physiological activity of the phytoplankton. The storm interrupted sampling on 25 and 26 April. When sampling was resumed on 27 April, the third eddy was in the study area. A second peak 
in euphotic zone $\mathrm{NO}_{3}$ was observed on 27 April which was caused by upwelling associated with the third eddy as well as vertical mixing resulting from the strong winds. Chlorophyll a peaked on 28 April, and primary production reached the highest value (ca. $6 \mathrm{~g} \cdot \mathrm{C} \cdot \mathrm{m}^{-2} \cdot \mathrm{d}^{-1}$ ) observed by us; a rate that may have been characteristic of much of the shelf break. A multispectral scanner flown by a NASA U-2 aircraft on 28 April showed that a 10-20 km wide surface chlorophyll patch (ca. $5 \mathrm{mg} \mathrm{\textrm {m } ^ { - }}$ ) extended for at least $90 \mathrm{~km}$ along the shelf break through our study area (Kim, McClain, Blaine, Hart, Atkinson and Yoder, 1980; Yoder et al., 19818). A similar instrument in the Nimbus 7 satellite showed that the patch extended along the inshore edge of the Gulf Stream front for several hundred $\mathrm{km}$ (C. R. McClain, personal communication). C assimilation number (euphotic zone integral). also reached its highest value (90 $\mathrm{mg} \mathrm{C} \mathrm{mg} \mathrm{Chl} \mathrm{a}^{-1} \mathrm{~d}^{-1}$ ) on $28 \mathrm{April}$, apparentiy .in response to the relatively high levels of euphotic zone $\mathrm{NO}_{3}$ and to a $50 \%$ increase in solar irradiance from 27 to 28 April (Fig, 6). By 30 April, primary production decreased to $1 \mathrm{~g} \mathrm{C} \mathrm{m}^{-2} \mathrm{~d}^{-1},<20 \%$ of the rate two days earlier. The decrease was a result of both lower euphotic zone chlorophyll a and lower $C$ assimilation numbers:- The decrease in:C assimilation number was probably related to the sharp drop in euphotic zone $\mathrm{NO}_{3}$ from 27-30 April as the third eddy moved out of the study area. In addition, incident irradiance was lower on 30 April than on the two previous days (Fig. 6).

Chain-forming centric diatoms and a pennate, Nitzschia sp., dominated the phytoplankton on 28 April (Table 1) when we observed highest rates of primary production (Fig. 5). At the 3 depths where phytoplankton were counted, diatom concentration was highest $\left(10^{6}\right.$. cells liter $\left.^{-1}\right)$ at $12 \mathrm{~m}$ (Table 1). Dinoflagellates and coccolithophorids were present at very low concentrations. Skeletonema costatum was the single most dominant species with a maximum concentration. of $3.5 \times 10^{5}$ cells liter -1 at $12 \mathrm{~m}$. The species composition was similar within 
upwelled waters at other shelf break stations that we sampled. In addition to the species shown in Table 1, large mats (ca. $1 \mathrm{~mm}^{2}$ or larger) of thousands of individual cells of the diatom, Thalassiosira subtilis (or similar species) were also observed, particularly below the mixed layer (see Summer Results). These mats were concentrated during oblique tows for zooplankton, and at times were so abundant that they discolored the nets and made the zooplankton samples difficult to process (G. -A. Paffenhöfer, personal communication).

APRIL, 1980

\section{Physical Description}

During the April, 1980 study, hydrographic, current meter, and production stations were all on the same transect at $30^{\circ} \mathrm{N}$ (Fig. 1). River runoff along the Georgia and South Carolina coasts was unusually high during the winter and spring of this year (approximately $2 \times$ the 20 year mean) and peaked in early April ( $J .0$. Blanton, unpublished) causing anomalously low surface salinities $\left(<35 \times 10^{-3}\right)$ along the middle and outer shelf (Fig. 7). The low surface salinities were a factor in stratifying the shelf earlier than was found in 1979 and other years. Stratification generally occurs later in the spring and is primarily a result of temperature difference. Early stratification of the shelf may explain why intruded GSW moved farther onto the shelf in Aprit 1980 than in April 1979 (see Atkinson, 1977). Figure 8 shows that the $5 \mu \mathrm{M} \mathrm{NO}$ isopleth extended as far shoreward as the $20 \mathrm{~m}$ isobath within a subsurface intrusion of upwelled GSW (confirmed by T-S analysis). In comparison, spring studies of upwelling in 1979 (Yoder et al., 1981B) and 1977 (Lee et al., 1981) found that $\mathrm{NO}_{3}$-rich waters only penetrated to about the $40 \mathrm{~m}$ isobath.

Current meter moorings were located near the production stations at the $40 \mathrm{~m}$ and $75 \mathrm{~m}$ isobaths. The shelf break moorings (75 $\mathrm{m}$ isobath) was equipped with 6 meters between 7 and $72 \mathrm{~m}$. At the $40 \mathrm{~m}$ isobath, 4 current meters were located 
between 7 and $37 \mathrm{~m}$. Data from these instruments indicated strong Gulf Stream influence throughout the study period (10-26 April). Current speeds at the shelf break were frequently in excess of $150 \mathrm{~cm} \mathrm{~s}^{-1}$ near the surface $(17 \mathrm{~m})$ and $50 \mathrm{~cm} \mathrm{~s} \mathrm{~s}^{-1}$ near the bottom. (72 m) (Fig. 9). Vertical shears between the top and bottom meter ranged from about $8 \times 10^{-3}$ to $2 \times 10^{-2} \mathrm{~s}^{-1}$. Upper layer mean_flows were toward the north at about $60 \mathrm{~cm} \mathrm{~s}^{-1}$ at the shelf break and $5 \mathrm{~cm} \mathrm{~s}-1$ at the $40 \mathrm{~m}$ isobath. Subtidal fluctuations of the along-shelf $(v)$ and cross-shelf $(u)$ velocity components and temperature $(T)$ indicate four Gulf Stream frontal disturbances propagated northward past the current meter arrays between 9 to 28 Apri] (Fig. 9). Northward propagation speeds were higher than observed in other years and ranged from $40-60 \mathrm{~km} \mathrm{~d}^{-1}$ as determined from current meters located north and south of the $30^{\circ} \mathrm{N}$ transect. The first event passed through the $30^{\circ} \mathrm{N}$ transect on 9-10. April, the second from-12-15 April, the third from 20-22 Apri1, and the fourth from 23-27 Apri1. Each event produced a cyclonic perturbation in the mean northward flow that occurred simultaneously with a large oscillation of temperature. These fluctuations were highly coherent and close in phase throughout the water column at both the 40 and $75 \mathrm{~m}$.. isobaths. . The onset of each disturbance produced onshore flow with decreasing temperature and decreasing northward speed throughout the water column at each location, however the effect was more pronounced near the shelf break.

Hydrographic time series from 12-26 April at the $30 \mathrm{~m}, 40 \mathrm{~m}$, and $50 \mathrm{~m}$ isobaths at $30^{\circ} \mathrm{N}$ are presented in Figure 7 . The series started after the first event and in the middle of the fourth, but the second and third events are apparent in the change in isotherm depth at the $40 \mathrm{~m}$. and $50 \mathrm{~m}$ isobaths. Wind speeds are shown in Figure $2 \mathrm{~B}$ and were never as strong as during the storm in Apri1, 1979. However, winds were frequently in excess of $10 \mathrm{~m} \mathrm{~s}^{-1}$ and may have been an important contributor to vertical mixing. Salinity changes at the $30 \mathrm{~m}$ 
and $40 \mathrm{~m}$ isobaths suggest a gradual mixing of relatively low salinity surface waters (initially $34 \times 10^{-3}$ ) with higher salinity water (initially $36 \times 10^{-3}$ ) lower in the water column during the course of the study (Fig. 7). Biological Effects

Figure 10 shows the vertical distributions of density, $\mathrm{NO}_{3}$, chlorophyll a , and the rates of $\mathrm{C}$ and $\mathrm{NO}_{3}-\mathrm{N}$ uptake at the $50 \mathrm{~m}$ isobath (shelf break) at $30^{\circ} \mathrm{N}$. As for the 1979 study, the water column was strongly stratified. The euphotic zone ( $1 \%$ isolume) at the shelf break was not as deep as in 1979 and was never deeper than $30 \mathrm{~m}$. The average chlorophyll a concentration of the mixed layer was $0.6 \mathrm{mg} \mathrm{m} \mathrm{m}^{-3}$ (compared to 1.5 in 1979), and primary production exceeded $5 \mathrm{mg} \mathrm{C} \mathrm{m} \mathrm{m}^{-3} \mathrm{~h}^{-1}$ in the mixed layer at only 1 of 7 stations (compared to 4 of 6 in 1979). Maximum primary production occurred below the mixed layer at 5 of 7 stations in 1980 . The vertical distribution in primary production generally closely followed the vertical distribution in the rate of $\mathrm{NO}_{3}-\mathrm{N}$ uptake being grossly different at only 1 station (April 20).

Figure 5 includes a time series (euphotic zone integrals) of primary production and $\mathrm{NO}_{3}$ uptake, chlorophyll a specific uptake rates of $\mathrm{C}$ and $\mathrm{NO}_{3}$ (assimilation numbers), and chlorophyll a and $\mathrm{NO}_{3}$ at the $50 \mathrm{~m}$ isobath (shelf break) at euphotic zone integrals of $30^{\circ} \mathrm{N}$ during Apri1, 1980. In general, chlorophyll a and $\mathrm{NO}_{3}$ were similar in 1979 and 1980, but at the shelf break, primary production was generally much lower in 1980. Figure 5 shows that lower $C$ assimilation numbers, rather than the amount of chlorophyll a, accounted for lower primary production. Temporal changes in primary production at the shelf break in 1980 showed a strong, visual correlation with $\mathrm{NO}_{3}$ uptake (Fig. 5). Temporal changes in primary production and $\mathrm{NO}_{3}$ uptake closely followed the trend in chlorophyll a specific uptake (i.e., C and $\mathrm{NO}_{3}$ assimilation numbers) and did not correlate with chlorophyll a or $\mathrm{NO}_{3}$. The peak in $\mathrm{C}$ and $\mathrm{NO}_{3}$ uptake (and in $\mathrm{C}$ and $\mathrm{NO}_{3}$ assimilation numbers) on 20 April may 
have been caused by a higher incident solar irradiance than on the tivo previous days (Fig. 6). The good correlation of $\mathrm{C}$ and $\mathrm{NO}_{3}$ uptake with $\mathrm{C}$ and $\mathrm{NO}_{3}$ assimilation numbers contrasts wịth 1979 results. In 1979, primary production correlated better with chlorophylf a than with $\mathfrak{C}$ assimilation number.

A subsurface intrusion of nutrient-rich GSW penetrated much farther onto the shelf in 1980 than in 1979 (Fig. 8). Time series of primary production and euphoti zone $\mathrm{NO}_{3}$ at the $30 \mathrm{~m}$ and $40 \mathrm{~m}$ isobaths at $30^{\circ} \mathrm{N}$ are presented in Figure 11 . Primary production there averaged 1.8 and $2.2 \mathrm{~g} \mathrm{C} \mathrm{m}^{-2} \mathrm{~d}^{-1}$ compared to $0.7 \mathrm{~g} \mathrm{C}^{-2} \mathrm{~d}^{-}$. at the shelf break. Average euphotic zone $\mathrm{NO}_{3}$ at the $40 \mathrm{~m}$ isobath $\left(2.1 \mathrm{~g} \mathrm{NO}_{3}-\mathrm{N} \mathrm{m}^{-2}\right.$ was about twice the average at the shelf break $\left(1.2 \mathrm{~g} \mathrm{NO}_{3}-\mathrm{N} \mathrm{m}^{-2}\right)$ and $30 \mathrm{~m}$ isobath (1.1 $\mathrm{g} \mathrm{NO}_{3}-\mathrm{N} \mathrm{m}^{-2}$ ). Chlorophyll a measurements, available from only 3 samplings at the $30 \mathrm{~m}$ and $40 \mathrm{~m}$ isobaths, showed that chlorophyll. a and C assimilation numbers were higher at the $30 \mathrm{~m}$ and $40 \mathrm{~m}$-isobaths than at the shelf break. C assimilation numbers were 33,48 , and $25 \mathrm{mg} \mathrm{C} \cdot \mathrm{mg} \mathrm{Chl} \underline{\mathrm{a}}^{-1} \mathrm{~h}^{-1}$ and average chlorophyl1 a was 40,44 , and $30 \mathrm{mg}$ chlorophyll a $\mathrm{m}^{-2}$ at $30 \mathrm{~m}, 40 \mathrm{~m}$, and shelf break, respectively. Thus, primary production was higher at the $30 \mathrm{~m}$ and $40 \mathrm{~m}$ isobaths than at the shelf break due to both higher chlorophyll a and C assimilation numbers. The trends in Figure 11 suggest that primary production at the $30 \mathrm{~m}$ and $40 \mathrm{~m}$ isobaths was related to the amount of $\mathrm{NO}_{3}$ in the euphotic zone.

\section{PRIMARY PRODUCTION IN RELATION TO BIOMASS}

To obtain average values for the 1979 and 1980 studies, C uptake was Iinearly in-tegrated with time and $1980 \mathrm{NO}_{3}$ uptake data were similarly integrated. Primary pro ction was $21.5 \mathrm{~g} \mathrm{C} \mathrm{m}^{-2} 8 \mathrm{~d}^{-1}\left(\bar{x}=2.7 \mathrm{~g} \mathrm{C} \mathrm{m}^{-2} \mathrm{~d}^{-1}\right)$ and $10.3 \mathrm{~g} \mathrm{C} \mathrm{m}^{-2} 15 \mathrm{~d}^{-1}(\bar{x}=0.7$ g $\left.C \mathrm{~m}^{-2} \mathrm{~d}^{-1}\right)$ in 1979 and 1980, respectively. Euphotic zone $\mathrm{NU}_{3}-\mathrm{N}$ uptake during the 1980 study was $1.4 \mathrm{~g} \mathrm{~N} \mathrm{~m}^{-2} 15 \mathrm{~d}^{-1}\left(\bar{x}=0.09 \mathrm{~g} \mathrm{NO}_{3}-\mathrm{N} \mathrm{m}^{-2} \mathrm{~d}^{-1}\right)$. Thus, the 15 day av àge $\mathrm{C}: \mathrm{NO}_{3}-\mathrm{N}$ uptake ratio in 1980 was 7.6 (by weight). A possible explanation for 
higher shelf break primary production in 1979 than in 1980 is that there was more chlorophyll a in the mixed layer in 1979 than in 1980. The base of the mixed layer was generally close to the $10 \%$ isolume. When nutrients reach the mixed layer, one expects higher specific growth rates than deeper in the water column because of higher mean levels of irradiance. Thus, a given amount of mixed layer chlorophyll a makes a larger contribution to primary production than euphotic zone

the same amount deeper in the water column. We regressed^primary production against chlorophyll a in the mixed layer to ascertain if the two were related (Fig. 12). Excluding the point with the highest residual, the regression had a linear correlation coefficient $(r)$ of $0.82(n=14)$. Thus, mixed layer chlorophyll a explains about $67 \%\left(r^{2}\right)$ of the variability in our primary production measurements within upwelled waters at the shelf break. A similar regression using the mean chlorophyll a concentration of the mixed layer rather than the integral yielded a similar result. Thus, mean chlorophyll a concentration of the mixed layer was more important to primary production than the depth of the mixed layer in our studies.

Particulate $C$ and $N$ were integrated over depth in the euphotic zone and compared with integrated uptake rates (Table 2 ). Both studies in spring showed similar euphotic zone integrals for POC, PON, and chlorophyll a. POC:PON ratios generally ranged from 5 to 10 (by weight), which is within the range often cited for marine waters containing significant amounts of phytoplankton (e.g., Collos and Lewin, 1976; Eppley, Renger and Harrison, 1979). The commonly used C:N ratio of marine plankton (Redfield ratio), 5.7 (by weight), is 1 ower than all but one of our measurements. During both spring studies, euphotic zone POC:Chl a ratios generally exceeded 100 with 4 of 13 stations having values higher than 200. Most ratios reported for marine waters that contain significant amounts of phytoplankton range from 50 to 150 (e.y., Durbin, Krawlec and Smayda, 1975; 
Huntsman and Barber, 1977; Malone, 1977; Eppley, Harrison, Chisholm and Stewart, 1977).

At the two depths at stations: where $\mathrm{NO}_{3}$ uptake measurements were made in 1979, the $\mathrm{C} / \mathrm{NO}_{3}-\mathrm{N}$ uptake ratio varied between 3.6 and 23 (Table 2). Some of this variability may be attributed to the limited number of $\mathrm{NO}_{3}$ uptake measurements in the 1979 study, since the 1980 results (euphotic zone integrals) fell within a relatively narrow range (6.3-13) (Table 2). High $\mathrm{C}: \mathrm{NO}_{3}$ uptake ratios indicate that another form of $N$ provided a significant fraction of phytoplankton $N$ demand. To calculate the importance of $\mathrm{NO}_{3}$ as a source of $\mathrm{N}$ ("new production" in sensu Dugdale and Goering, 1967), the uptake rates of other forms of $N$ (e.g., $\mathrm{NH}_{4}$ ) should be known but were not measured. To obtain an estimate of new production, we assumed that phytoplankton assimilated $C$ and all forms of $N$ (total-N) according to the Redfietd ratio. By comparing öbserved $\mathrm{C}: \mathrm{NO}_{3}$ uptake ratios with this ratio (5.7), we calculated the percentage of total $N$ demand that could be accounted for solely by $\mathrm{NO}_{3}$ uptake and refer to this percentage as "new production". New production at the 2 depths sampled at each station in 1979 ranged from 25-100\% of total primary production (Table 2). In 1980, euphotic zone new production ranged from 44 to $90 \%$ of the total. The 15 day average $\mathrm{C}: \mathrm{NO}_{3}$ uptake ratio (7.6) in 1980 yields an average new production of about $75 \%$.

The last columns of Table 2 are estimates of $C$ and "new $N$ " euphotic zone doubling times. By doubling time, we mean the time it takes to synthesize an amount of $\mathrm{C}$ and $\mathrm{N}$ equivalent to the observed POC and PON at each station using observed rates of $\mathrm{C}$ and $\mathrm{NO}_{3}-\mathrm{N}$ uptake. Carbon doubling time was much faster in 1979 ranging from 1.7 to 9.5 däys versus 3.5 to 68 days in 1980 . Using average values for both POC and C uptake, C doubling time averaged 4 days in 1979 and 13 days in 1980. Our definition of "new N" doubling time (i.e., based only on $\mathrm{NO}_{3}$ uptake, not total-N uptake) is not the same as our definition of $\mathrm{C}$ doubling 
time. With high grazing rates and efficient nutrient recycling, one could observe rapid $C$ doubling times without significant net increases in POC nor a significant net $C$ flux into other pools (e.g., zooplankton, sinking losses). However, since upwelled $\mathrm{NO}_{3}$ is an addition of new $\mathrm{N}$ to the euphotic zone, $\mathrm{NO}_{3}$ uptake should cause an.increase in PON or net $N$ flux into another pool. New $N$ doubling time ranged from 2.7 to 100 days in 1980. The average euphotic zone PON and average $\mathrm{NO}_{3}$ uptake rate yielded an average new $\mathrm{N}$ doubling time of 10.5 days. Though average new $N$ doubling time is significantly less than the duration of our study (15 days) PON did not increase in the euphotic zone at the shelf break (Table 2). Thus euphotic zone PON was either transferred to another pool or was advected away from the shelf break.

Relatively high POC:Chl $\underline{a}$ and POC:PON ratios imply that phytoplankton were not the only important contributor to POC and PON: We calculated the percentage of POC not accounted for by phytoplankton $C$ by three different methods (Table 3): (1) a constant phytoplankton $C: C h 1$ a ratio of 50 , (2) a constant phytoplankton C:Chl a ratio of 100, and (3) the equation of Eppley et al. (1977), where phytoplankton $C=0.158(P O C)+0.0007(P O C)^{2}$. Non-phytoplankton $C$ was obtained by substracting the result of each of the estimates from measured POC. For each of the three methods, we used phytoplankton $C: N$ ratios of 5 and 10 and calculated by difference the $C: N$ ratios of the non-phytoplankton particulates (Table 3 ). The equation of Eppley et al. (1977) yielded results similar to those of either one or the other of the other two estimate, so the results of estimate (3) are not shown. Since phytoplankton $\mathrm{C}: \mathrm{Chl}$ a ratios generally fall between 50 and 100 , and phytoplankton $C: N$ ratios are generally between 5 and 10 , the matrix shown (Table 3) should cover the range of probable values for non-phytoplankton $C$. Regardless of which method was applied to estimate phytoplankton $C$, the results show that if the phytoplankton $C: N$ ratio was closer to 5 thar to 10 , then the 
C:N ratio of non-phytoplankton particulates was much greater than 10 (Table 3 ). $C: N$ ratios greater than 10 imply that non-phytoplankton particulates are primarily detritus rather than small zooplankton or bacteria which have $C: N$ ratios less than 5. Results from 1979 and 1980. showed that non-phytoplankton C ranged from about $30 \%$ to $70 \%$ depending on whether we assumed a phytoplankton $\mathrm{C}: \mathrm{Chl}$ a ratio of 100 or 50 , respectively.

AUGUST, 1978

Physical Description

XBTs taken along the outer shelf on 4 August, 1978, showed a subsurface intrusion of GSW between $30^{\circ}$ and $30^{\circ} 30^{\prime} \mathrm{N}$. Bottom temperatures were as low as $17^{\circ} \mathrm{C}$ at the $40 \mathrm{~m}$ isobath compared to surface mixed layer temperatures of $28^{\circ} \mathrm{C}$ (see Blanton et al., 1981). The cold water intrusion had been on the shelf for only a few days because a cross-sheif section at $30^{\circ} \mathrm{N}$ on 27 July, 1981, showed bottom temperatures of $21.1^{\circ} \mathrm{C}, 24.2^{\circ} \mathrm{C}$, and $24.7^{\circ} \mathrm{C}$ at the 50,40 and $30 \mathrm{~m}$ isobaths, respectively. XBT and CTD surveys on 4 and 5 August showed that the intrusion. was about $40 \mathrm{~km}$ in diameter, and that isotherms less than $22^{\circ} \mathrm{C}$ were cut off from source waters farther offshore ("stranded") in the cross-shelf axis and possibly also in the along-shore axis (Blanton et al., 1981). A drogue was deployed on 5 August near the center of the intrusion. The top of the drogue sail was at $24 \mathrm{~m}$ which corresponded to the $22^{\circ} \mathrm{C}$ isotherm. The drogue which was used as a reference station from 5 August $(T=0)$ until 14 August $(T=9)$ was located at the $37 \mathrm{~m}$ isobath on 5 August and near the $30 \mathrm{~m}$ isobath by 7 August. It remained close to the $30 \mathrm{~m}$ isobath for the remaining days of the study. During the 9 day study the drogue moved $61 \mathrm{~km}$ on a bearing of 345 degrees with a mean velocity of about $8 \mathrm{~cm} \mathrm{~s}^{-1}$ (Fig. 1). Prevailing winds were light from the south and southeast, and seas were calm. Four temperature sections, each centered by the position of the drogue, show that the drogue stayed near the center of the intrusion 
as defined by stranded isotherms less than $22^{\circ} \mathrm{C}$ (Fig. 13).

\section{Biological Effects}

Chlorophyll a and $\mathrm{NO}_{3}$ time series at the drogue are shown in Figure $14 . \mathrm{NO}_{3}$ was initially as high as $10 \mu M$ within the intrusion and less than $1.0 \mu M 7$ days later. Dissolved inorganic. Si and $P$ also decreased with time with dissolved Si as high as $12 \mu g$-atoms 1 iter $^{-1}$ initially,decreasing to less than $3 \mu g$-atoms liter ${ }^{-1}$ by the final two days. Chlorophyll a was less than $2 \mathrm{mg} \mathrm{m}^{-3}$, in the subsurface intrusion for the first 3 days and exceeded $7 \mathrm{mg} \mathrm{m} \mathrm{m}^{-3}$ by the sixth day. Temporal increases in chlorophyll a within the intrusion were accompanied by decreased $\mathrm{NO}_{3}$ (Fig. 14).

From 7 August $(T=2)$ until the end of the study $(T=9)$, the surface mixed layer and the intrusion (temperatures less than $25^{\circ} \mathrm{C}$ ) were each about $15 \mathrm{~m}$ thick. Mean chlorophyll a concentration in the mixed layer ranged from 0.2 to $0.35 \mathrm{mg} \mathrm{m}^{-3}$ and $\mathrm{NO}_{3}$ was always below detection limits. Mean chlorophyll a concentration in the intrusion was initially $0.4 \mathrm{mg} \mathrm{m}^{-3}$ and peaked at $4 \mathrm{mg} \mathrm{m}^{-3}$ on 12 August $(\mathrm{T}=7)$, i.e., a 10 fold increase. During the final 3 days of the study, mean chlorophyll a in the intrusion was 10-15 times greater than in the surface mixed layer. Mean $\mathrm{NO}_{3}$ and chlorophy 11. a concentrations of the intrusion are shown as a function of time in Figure 15. From $T=1$ until $T=7$, the doubling time of intrusion chlorophyll $\underline{a}$ was 1.5-2.0 days assuming exponential increase (Fig. 15). During the same period, the half-life of $\mathrm{NO}_{3}$ was 1.5-2.0 days assuming exponential decrease (Fig. 15). After $T=7$, average chlorophyll a in the intrusion decreased. Further decay of the phytoplankton bloom was not followed.

Light-limited cultures of the marine diatom, Skeletonema costatum grown at 16 and $22^{\circ} \mathrm{C}$ with $\mathrm{NO}_{3}$ as the source of $\mathrm{N}$, had $\mathrm{PON}: \mathrm{Ch}$ l a ratios close to 6 (Yoder, 1979). Mean $\mathrm{NO}_{3}$ concentrations of intrusion waters decreased to $6 \mu M\left(91 \mathrm{mg} \mathrm{m}^{-3}\right.$ ) from $T=1$ to $T=7$ (peak of the phytoplankton bloom). If the 
PON:Chl a ratio of intrusion phytoplankton was similar to light-limited $\underline{\text { s. }}$ costatum cultures, the average chlorophyll a concentration should have been $15 \mathrm{mg} \mathrm{m}^{-3}$ on $T=7$, rather than the observed $4 \mathrm{mg} \mathrm{m}^{-3}$. This implies that a high proportion of phytoplankton production was lost from the phytoplankton pool during the bloom. If the loss occurred at a constant exponential rate (e.g., due to zooplankton grazing), the average specific rate of "new production" of intrusion phytoplankton was $0.6 \mathrm{~d}^{-1}$ between $T=1$ and $T=7$ compared to the specific rate of chlorophyll a increase of $0.4 \mathrm{~d}^{-1}$ (i.e., a measure of net growth).

During the first 5 days. $\mathrm{C}$ and $\mathrm{NO}_{3}$ uptake rates were determined at a single depth within the intrusion. $C$ uptake was measured in a laboratory incubator at 10 levels of irradiance ranging from 5 to $60 \mu$ Einst. $\mathrm{m}^{-2} \mathrm{~s}^{-1}$. In comparison, the average daily irradiance (light period only) of the intrusion (15-30 $\mathrm{m}$ ) ranged from 46 to $82 \mu$ Einst. $\mathrm{m}^{-2} \mathrm{~s}^{-1}$ (calculated from equation 4 ). $\mathrm{NO}_{3}$ uptake was measured at $35 \mu$ Einst. $\mathrm{m}^{-2} \mathrm{~s}^{-1}$, the average daily light period irradiance at 24-29 $\mathrm{m}$. The relation between assimilation number ( $\mathrm{mg} \mathrm{C} \cdot \mathrm{mg} \mathrm{Chl} \underline{a}^{-1} \mathrm{~h}^{-1}$ ) and irradiance was linear at these low irradiance levels $;$ and straight lines were fit to the results of each experiment $(n=6)$. Examples of the regressions having highest and lowest correlation coefficients are shown in Figure 16 . The $x$-axis intercept of the regression lines (compensation irradiance) ranged from -1.2 to $8.3 \mu$ Einst. $\mathrm{m}^{-2} \mathrm{~s}^{-1}(400-700 \mathrm{~nm})$. Excluding the single negative result for $I_{C}$ (compensation irradiance), average $I_{c}$ was 4.3 kEinst. $m^{-2} s^{-1}(n=5)$. This corresponds to about $0.4 \%$ of average incident solar irradiance on a cloudless summer day. The attenuation coefficient at the drogue station was $0.11 \mathrm{~m}^{-1}$, and thus $I_{C}$ occurred at $50 \mathrm{~m}$. The slope (a) of the regressions ranged from 19-36

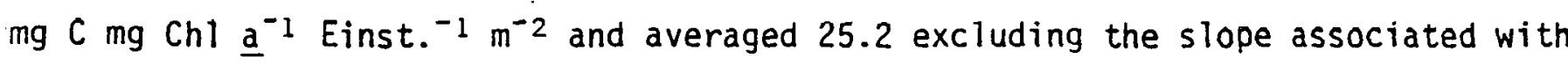
the negative $I_{C} \cdot \mathrm{C}: \mathrm{NO}_{3}-\mathrm{N}$ uptake ratio at $35 \mu$ Einst. $\mathrm{m}^{-2} \mathrm{~s}^{-1}$ ranged from 3.4 to 
58 and showed no trend with time, temperature, or $\mathrm{NO}_{3}$ concentration.

We used equations 2-5 to estimate daily primary production in the intrusion during the period of rapid increase in mean chlorophyll a and decrease in mean $\mathrm{NO}_{3}$ concentration $(T=1$ to $T=7)$.

$$
I_{O m}=I_{\max }(A)(B)(C)(D)
$$

where, $I_{\max }=600 \mathrm{ly} \mathrm{d}^{-1}$ (from pyranometer located at Skidaway Institute of Oceanography, Savannah, Georgia)

$A=$ photosynthetically active irradiance $\left(0.5 \mathrm{I}_{\max }\right)$

$B=\%$ sunshine (Fig. 6).

$C=0.85$ ( $i . e ., 15 \%$ reflectance off the sea surface; Strickland, 1958)

$0=1$ ly of sunshine $=0.2$ Einst. $\mathrm{m}^{-2}$ (Strickland, 1958)

$$
I_{15 m}=I_{0 m} \text { e }(-k z)
$$

where, $z=15 \mathrm{~m}$

$$
k=0.11 \mathrm{~m}^{-1} \text { (measured) }
$$

$$
\bar{I}_{15-30 m}=\left[I_{15 m}\left(1-e^{(15 k)}\right)\right] 15 k
$$

where, $\bar{I}_{15 m-30 m}$ is the mean irradiance between $15-30 \mathrm{~m}$

$$
\begin{aligned}
& \text { Daily primary production }=\left(\bar{I}-\bar{I}_{c}\right)(\underline{\bar{a}})\left(\Sigma_{15 \mathrm{~m}}^{30 \mathrm{~m}} \mathrm{Ch} \text { l } \underline{\mathrm{a}}\right) \\
& \text { where, } \\
& \underline{\bar{a}}=\text { mean initial slope (see text) } \\
& \bar{I}_{c}=\text { mean compensation irradiance (see text) } \\
& \Sigma \mathrm{Chl} \underline{a}=\text { average daily chlorophyll a (from Fig. 13) }
\end{aligned}
$$

Equations 2-5 yielded daily primary production estimates ranging from 0.4 $(T=1)$ to $4.1(T=7)$ g. C $\mathrm{m}^{-2} \mathrm{~d}^{-1}$. The total primary production for the 7 day period at depths between 15 and $30 \mathrm{~m}$ was $13.5 \mathrm{~g} \mathrm{C} \mathrm{m}^{-2}$ or an average of $1.9 \mathrm{~g} \mathrm{C} \mathrm{m}^{-2} \mathrm{~d}^{-1}$. Primary production of the surface mixed layer (15 m thick) measured on two separate days $(T=4$ and $T=7)$ averaged $0.4 \mathrm{~g} \mathrm{C} \mathrm{m}^{-2} \mathrm{~d}^{-1}$. Thus, primary production in the upper $15 \mathrm{~m}$ (mixed layer) was approximately equivalent to that of the intrusion $(15-30 \mathrm{~m})$ during the early stages of the bloom within the intrusion. 
but was only about $10 \%$ of intrusion primary production at the peak of the bloom. Average $C$ assimilation number was higher in the surface mixed layer than in the intrusion, but the intrusion had substantially higher chlorophyll a concentrations. The change in $\mathrm{NO}_{3}$ concentration in the intrusion during the same period was $-1.3 \mathrm{~g} \mathrm{NO}_{3}-\mathrm{N} \mathrm{m}^{-2} 7 \mathrm{~d}^{-1}$. Thus, the 7 day primary production and $\mathrm{NO}_{3}-\mathrm{N}$ uptake estimates yield a calculated $\mathrm{C}: \mathrm{NO}_{3}-\mathrm{N}$ uptake ratio of 10.4 or $55 \%$ new production using earlier assumptions.

Cell counts and particulate Si analyses showed that the intrusion at the drogue station was dominated by diatoms. Of the phytoplankton taxa commoniy found in marine waters, diatoms are the only important group that contain significant amounts of Si. A linear regression (minus the point having highest residual sums of squares from an initial regression) of chlorophyll a against particulate si below $15 \mathrm{~m}$ at different times yielded a correlation coefficient of $0.93(n=26)$ with a $Y$-axis intercept close to zero (-.06) (Fig. 15). Diatom species listed in Table 4 are ordered by their approximate cell volume. The dominate diatoms in the intrusion initially had a wide range in mean cell volume $\left(10^{2}\right.$ to $\left.4 \times 10^{6} \mathrm{\mu m}^{3}\right)$. By the end of the study, however; larger diatoms dominated. As in spring, 1979, mats of the diatom, Thalassiosira subtilis (or similar species), occurred in large numbers. The mats, particularly noticeable in zooplankton nets after tows within the intrusion (G. -A. Paffenhöfer, personal communication), were composed of a gelatinous matrix consisting of thousands of individual cells approximately $10 \mu \mathrm{m}$ in diameter, and thus accurate enumeration of this species vas not attempted. The relative abundance of I. subtilis, however, was determined by microscopically examining the area covered by the mats on the bottom of settling chambers. This method showed that I. subtilis became a major component of the phytoplankton by the end of the intrusion study (Table 4). 


\section{DISCUSSION}

Comparison of the Three Studies

Our results show that shelf break upwelling and intrusion of NACW onto the outer shelf leads to moderately high rates of primary production (ca. $1 \mathrm{~g} \mathrm{C} \mathrm{m}^{-2} \mathrm{~d}^{-1}$ or more) of which a significant percentage (> 50\%) is "new production". Despite differences in average primary production and the seasons during which our studies were conducted (spring and summer), all three showed important similarities. During all three studies, a high proportion of primary production was "new production" - i.e., upwelled $\mathrm{NO}_{3}$ was a principal source of $\mathrm{N}$. Best supporting evidence was obtained during spring, 1980, when the vertical changes in primary production closely followed $\mathrm{NO}_{3}$ uptake rates. Secondly, temporal changes in primary production closely followed trends in $\mathrm{NO}_{3}$ uptake (both integrated over the euphotic zone). Because of the small number of $\mathrm{NO}_{3}$ uptake experiments conducted in 1979, evidence supporting a high percentage of new production is not as convincing. However, temporal changes in primary production in 1979 followed trends in euphotic zone $\mathrm{NO}_{3}$ (with a 1 day $\mathrm{lag}$ ) suggesting a relation between the two. Finally, during summer 1978, the decline in intrusion $\mathrm{NO}_{3}$ coincided with increase in plant biomass (chlorophyll a ), providing strong indirect evidence that $\mathrm{NO}_{3}$ was a primary source of $\mathrm{N}$.

Phytoplankton species were not enumerated in Apri1, 1980 but during the other two studies upwelled waters were dominated by diatoms. Detailed floristic surveys (Marshal1, 1971; Hulburt, 1967) earlier showed that, in general, southeastern shelf waters are dominated by diatoms. Marshall (1971), who analyzed samples from all seasons of the year, concluded that $\underline{5}$. costatum and Rhizosolenia spp. were the most abundant diatoms. Other investigators later reported that diatoms generally dominate intruded GSW, but the dominate species were not always the same. Bishop et al. (1980) showed that an April intrusion 
of GSW was principally dominated by $\underline{S}$. costatum, whereas Paffenhöfer (1980) found that large Rhizosolenia spp. were abundant in a summer intrusion into Onslow Bay, North Carolina. Summer intrusions off the Georgia/florida coasts were also characterized by: significant numbers of Rhizosolenia spp. (Paffenhöfer and Dunstan, unpublished). The Chrysophyte, Phaeocystis pouchetii, was so abundant in a summer intrusion off the north Florida coast that quantitative zooplankton tows could not be made (Atkinson et al., 1978).

Phytoplankton productivity differed significantly during our three studies, and these differences are at least partially explained by differences in the physical dynamics of water motion. Primary production was highest $(\bar{x}=2.7 \mathrm{~g}$ $\mathrm{C} \mathrm{m}^{-2} \mathrm{~d}^{-1}$ ) in spring, 1979. Prior to, and during the early phase of this study, two large Gulf Stream frontal eddies passed-through our study area, and measurements were initially neär the center of an upwelled cold core (Yoder et al., 1981B). A third eddy came through only days later, and strong winds may have enhanced nutrient flux into the euphotic zone. To examine the relative "strength" of upwelling in spring, 1979, we calculated the net nitrate flux to the outer shelf over 12 days using the method described by tee et al. (1981). In brief, Lee et al. used continuous temperature and current records and the constant $\mathrm{NO}_{3} /$ temperature relation of GSW to calculate the net onshore flux of $\mathrm{NO}_{3}$ at the shelf break. During the 7 day duration of a frontal eddy studied in April, 1977, Lee et al. (1981) showed that net onshore $\mathrm{NO}_{3}$ flux averaged 18.6 umoles $\mathrm{m}^{-2} \mathrm{~s}^{-1}$ compared to the average onshore flux between December, 1976 and April, 1977, of $8.5 \mu$ moles $\mathrm{m}^{-2} \mathrm{~s}^{-1}$. The latter estimate reflects the averaged contribution of many separate upwelling events: In comparison, the net onshore $\mathrm{NO}_{3}$ flux during our 1979 study averaged 34.4 umoles $\mathrm{m}^{-2} \mathrm{~s}^{-1}$, or about twice the rate of the 1977 eddy and about 4 times the seasonal average. This suggests that upwe11ing was unusually strong during the 1979 study. 
No large frontal eddy passed through the study area during the April, 1980 study. However, four smaller upwelling-favorable events were detected by shelf break current meter arrays, and $\mathrm{NO}_{3}$-rich GSW penetrated well onto the shelf at $30^{\circ} \mathrm{N}$. Early stratification of the shelf was the probable cause of seasonallyatypical cross-shelf penetration. At the 30 and $40 \mathrm{~m}$ isobaths, temporal changes in vertical salinity distributions suggested vertical mixing between $\mathrm{NO}_{3}-\mathrm{rich}$ bottom waters and the mixed layer during the 15 day time series. Primary production was higher at the 30 and $40 \mathrm{~m}$ isobaths than at the shelf break which may have been in part due to more $\mathrm{NO}_{3}$ within the euphotic zone.

At the shelf break, average primary production was much lower during 1980 than 1979 ( 0.7 versus $\left.2.7 \mathrm{~g} \mathrm{C} \mathrm{m}^{-2} \mathrm{~d}^{-1}\right)$. Because euphotic zone chlorophyll $\underline{\mathrm{a}}$ was generally similar during both studies, the difference in primary production principally resulted from lower C assimilation numbers in 1980 . We hypothesize that assimilation numbers were lower in 1980 than in 1979 because a much higher percentage of chlorophy11 a was below the mixed layer (ca. $10 \%$ isolume) in 1980, and thus light-limitation was more severe than in 1979.

Physical conditions during the summer, 1978, drogue study were different from both of the spring studies. A subsurface intrusion of upwelled GSW penetrated well onto the shelf and separated from source waters - i.e., isotherms less than $22^{\circ} \mathrm{C}$ did not extend into deeper offshore waters. Winds were light and displacement of the drogue showed that the intrusion center moved north at a relatively slow speed (ca. $8 \mathrm{~cm} \mathrm{~s}^{-1}$ ). The linear relation between primary production and light up to an irradiance level that was close to the mean for the subsurface intrusion showed that phytoplankton were light-limited, at least during the first 5 days of the study. Although all detectable $\mathrm{NO}_{3}$ (and eventually more than $90 \%$ of the chlorophyll a) was below the $10 \%-20 \%$ isolume, the residence time of the intrusion on the shelf (greater than 10 days) was long enough for 
light-limited phytoplankton to convert virtually all of the $\mathrm{NO}_{3}$ into plant biomass. In spite of light-limitation the average production within the subsurface intrusion was about 5 times greater than that of the overlying mixed layer, because chlorophyll a concentrations were much greater.

Seasonal Estimates of Primary Production

Haines and Dunstan (1975) measured primary production across the southeastern shelf during 4 seasonal cruises of about 7 days duration during 1973-74. As their study was completed before the potential importance of upwelling along the Gulf Stream front was recngnized, they did not distinguish between rates obtained in upwelled waters and those that, were not. For coiliparative purposes, we assume that their very low average rate of primary production $\left(0.05 \mathrm{~g} \mathrm{C} \mathrm{m}^{-2} \mathrm{~d}^{-1}\right)$ reported at the 20-200 $\mathrm{m}$ isobaths during April is representative of the outer shelf in the absence of upwelled GSW:- Average primary production with in upwelled waters during Apri], 1979 and 1980 reported here was respectively, about 50 and 14 Limes greater than the average April rate reported by Haines and Dunstan (1975), and the highest rate $\left(6 \mathrm{~g} \mathrm{C} \mathrm{m}^{-2} \mathrm{~d}^{-1}\right)$ measured by us was more than 100 times greater than thefr average. This comparison illustrates why it is important to consider the effects of specific events such as upwelling when estimating seasonal primary production on the outer shelf. Obviously, the extent to which upwelling influences annual or seasonal estimates of areal production depends on the frequency of the upwelling events, their duration, and the area influenced.

The frequency of upwellings was estimated from the racords of a long-term current meter mooring located at the shelf break (75 $\mathrm{m}$ isobath) off the Georgia coast $\left(31^{\circ} 30^{\prime} N\right)$. Four records were available between November-April. Upwelling events were identified by onshore flow near the bottom coupled with a drop in near-bottom temperature, and we ignored all interruptions of onshore flow that lasted for less than $24 \mathrm{~h}$. Results from the four records showed that upwelling 
occurred from $40 \%-65 \%$, averaging $53 \%$, of the time. The number of events during the same period averaged 4-5 per month.

Hydrographic data collected during. the November-April period shows that nutrient-rich upwelled GSW is usually constrained to the outer shelf between about the $40 \mathrm{~m}$ to $200 \mathrm{~m}$ isobaths - a distance of about 30-40 km (Atkinson, 1977, unpublished; Lee et al., 1981; Yoder et al., 1981B; Yoder, unpublished manuscript). Except in waters shoreward of the $20 \mathrm{~m}$ isobath, relatively high chlorophyll a concentrations occur only within upwelled GSW (Bishop et al., 1980; Yoder et all:, 1981A; Yoder et al., 1981B; Yoder, unpublished manuscript). During months when the shelf is not stratified (ca. November-April), wave-like disturbances propagate along the cyclonic Gulf Stream front with characteristic periods and propagation speeds and cause upwelling which generally affects only the outer part of the continental shelf. For these reasons, we will assume that seasonal primary productivity does not change significantly along the length of the outer southeastern shelf when shelf waters are not stratified. Possible exceptions may be the outer shelf just north of Cape Canaveral, Florida and off the coast of North Carolina, where Blanton et al. (1981) showed that upwelling and intrusion of GSW may occur more frequently than off the north Florida, Georgia, and South Carolina coasts. Whether alongshore differences in upwelling frequency cause alongshore differences in primary production is not known.

Average primary production in upwelled waters on the outer shelf during November-April (most measurements were made in April) was $1.8 \mathrm{~g} \mathrm{C} \mathrm{m}^{-2} \mathrm{~d}^{-1}(n=23)$. This average and the average number of days that upwelling occurred (i.e., $53 \%$ of the time) implies a 6 month primary production during upwelling of about $175 \mathrm{~g} \mathrm{C} \mathrm{m}^{-2}$. We assume the average daily primary production during April 10.05 $g\left(\mathrm{~m}^{-2} \mathrm{~d}^{-1}\right)$ reported by Haines and Dunstan (1975) represents conditions on the outer shelf when upwelled waters are absent. Combining rates for non-upwelling 
and upwelling conditions yields a primary productivity estimate of about $180 \mathrm{~g}$ $C \mathrm{~m}^{-2} 6 \mathrm{mo}^{-1}$ on the outer shelf during November-April. Based on hydrographic data, the outer $40 \mathrm{~km}$ of the shelf (about the outer third of the shelf off the Georgia coast) is the approximate spatial scale to which this productivity estimate applies.

One major limitation of our estimate is that by using an average value for primary production, we ignore the time dependence of primary production during the development of phytoplankton blooms. Secondly, we assume that upwelling events are similar throughout the November-April period even though most of our measurements were made in April. Hydrographic, satellite, and current meter data show that relevant shelf break physical processes (i.e., meanders and eddies) occur throughout the November-April period, supporting the latter assumption. In addition, chlorophyll a measurements show consistent relations with hydrography, i.e., high concentrations on the outer shelf are only found within intruded GSW regardless of season. In spite of the above uncertainties, our productivity estimate is a first attempt to recognize and account for the effects of dominant processes that introduce nutrients into the euphntir zone on the outer southeastern shelf. Obviously a better estimate could be obtained with a long time series (weeks-months), but frequent measurements (ca. 1 per day) would be required to resolve the effects of upwelling events.

Haines and Dunstan (1975) also estimated an annual primary production of $285 \mathrm{~g} \mathrm{C} \mathrm{m}^{-2} \mathrm{yr}^{-1}$ fonr the inner shelf of the Georgia Bight $10 \mathrm{~m} 20 \mathrm{~m}$ isobaths or roughly the inner third of the shelf). Thomas (1966) showed that primary production near the mouth of the Altamaha River was about $600 \mathrm{~g} \mathrm{C} \mathrm{m}^{-2} \mathrm{yr}^{-1}$. Our 6 month estimate for the outer shelf suggests that production there may exceed average inner shelf production and may be as much as $60 \%$ the rate of primary production near the mouth of a major southeastern river. This contradicts earlier 
conclusions concerning productivity across the southeastern shelf (Haines, 1974; Haines and Dunstan, 1975; Turner et al., 1979) but is consistent with the hypotheses advanced by Dunstan and Atkinson (1976), Bishop et al. (1980) and Yoder et al., $(1981 A, 1981 B)$.

Our results show that new production during upwelling is $50 \%$ (about $85 \mathrm{~g}$ $C \mathrm{~m}^{-2} 6 \mathrm{mo}^{-1}$ ) or more of total primary production. This is more than 10 times higher than the new production estimate of Haines (1974) and Dunstan and Atkinson (1976) for the November-April period. The latter study concluded that intrusions of GSW were an important source of nitrogen only during summer. Lee et al. (1981) estimated that the net flux of nitrate onto the outer shelf from eddies could support a rate of new production of about $60 \mathrm{~g} \mathrm{C} \mathrm{m}^{-2} \mathrm{yr}^{-1}$ ( $\underline{\mathrm{ca}} .30 \mathrm{~g} \mathrm{C} \mathrm{m}^{-2} 6 \mathrm{mo}^{-1}$ ), which is less than $50 \%$ of the new production estimate given here. Lee et al. (1981) estimated nitrate flux using only near-surface and near-bottom current. meters to describe onshore-offshore currents during upwelling. More recent studies (Lee, unpublished) that employed up to 6 current meters spaced throughout the water column at the $75 \mathrm{~m}$ isobath showed that the results from just 2 current meters grossly underestimated onshore flow (and thus onshore nitrate flux). An improved estimate of eddy-induced $\mathrm{NO}_{3}$-flux was made using data from the shelf break mooring located at $30^{\circ} \mathrm{N}$ during April, 1980. Using this data and assuming 1 eddy every 14 days yields a $\mathrm{NO}_{3}$ flux to the shelf that could resuit in maximum "new" production of $160 \mathrm{~g} \mathrm{C} \mathrm{m}^{-2} 6 \mathrm{mo}^{-1}$ (assuming the Redfield ratio of 5.7 to convert phytoplankton $N$ to $C$ ). Our estimate of "new" production (based on uptake measurements) of $85 \mathrm{~g} \mathrm{C} \mathrm{m}^{-2} 6 \mathrm{mo}^{-1}$ is less by half than potential new production from eddy-induced upwelling alone. This suggests that most upwelled $\mathrm{NO}_{3}$ is not assimilated by phytoplankton during the November-April period.

Shelf break current meter records during May-October (stratified shelf) show that upwelling frequency is comparable to that of November-April (Lee, unpublished). 
However, no one has yet reported low temperatures $\left(<22^{\circ} \mathrm{C}\right)$, high $\mathrm{NO}_{3}$, or high chlorophyll a concentrations in the mixed layer on the outer shelf (ca. $40-200 \mathrm{~m}$ isobaths) during summer such as we found during spring (e.g., April, 1979) or observed by others during winter (Bishop et al:, 1980; Yoder, unpublished). Thus, our average value for outer shelf primary production during November-April may not apply during the remaining months of the year, since our average includes results obtained during strong upwelling in April, 1979 when mixed layer production was very high. Our summer, 1978 study illustrates another reason why outer shelf primary production may be lower during May-October than in NovemberApril. When the shelf is stratified, upwelled GSW penetrates well onto the shelf and at times, becomes isolated from source waters farther offshore (Atkinson, 1977). This situation arises when an upwelling favorable Gulf Stream disturbance is coupled with southerly winds that increase onshore flow in the bottom layer (Hofmann, Pietrafesa and Atkinson, 1981; 0'Malley, 1981). Prevailing winds during summer have a strong southerly component (Weber and Blanton, 1980). When a subsurface intrusion is stranded, water column nutrients are highest at the center of the intrusion, which can be shoreward of the $40 \mathrm{~m}$ isobath (e.g., summer, 1978), than on the outer shelf. Under these circumstances, we expect event-averaged primary production to be higher toward the center of the intrusion than on the outer shelf. A major study is planned to address upwelling dynamics and biological effects during summer conditions. Comparison with wind-driven Upwelling Systems

The major wind-driven upwelling systems off the west coast of the U.S., Peru, and northwest Africa have been studied for years, and a far larger data base is available for these areas than for the outer southeastern shelf. Despite the relatively few data for the southeast shelf, some preliminary comparisons illustrate important differences between the wind-driven systems and Gulf Stream- 
induced upwelling. The most obvious difference is the amount of $\mathrm{NO}_{3}$ in the mixed layer. We have never observed more than $5 \mu \mathrm{NO}_{3}$ in the mixed layer on the outer southeastern shelf and concentrations that high are rare. In comparison, mixed layer $\mathrm{NO}_{3}$ often exceeds 10 Hll during upwelling off Baja California (e.g., Walsh, Whitledge, Kelley, Hunstman and Pillsbury, 1977), Oregon (Small and Menzies, 1981), northwest Africa (Codispoti and Friederich, 1978), and Peru (Kelley, Whitledge and Dugdale, 1975). Secondly, upwelling is aseasonal on the southeast U.S. shelf and upwelled nutrient-rich waters are rapidly (daysweeks) removed from the outer shelf inbetween events, especially when the shelf is not stratified. This causes rapid (days-weeks), and extreme, "relaxations" in the biological response, since the outer shelf changes from relatively high primary production during upwelling to essentially oceanic conditions as upwelled waters downwell or advect from a fixed location on the shelf. During the upwelling season, in the aforementioned wind-driven systems, relaxations occur inbetween wind events, but the biological response does not drop to oceanic levels. For example, primary production averaged $2 \mathrm{~g} \mathrm{C} \mathrm{m}^{-2} \mathrm{~d}^{-1}$ during a 2 month (seasonal) study off northwest Africa (Huntsman and Barber, 1977) which slightly exceeds average primary production during upwelling events on the outer southeastern shelf. Finally, strong wind-driven upwelling destratifies the water column to the extent that the mixed layer depth considerably exceeds the depth of the euphotic zone. Under these circumstances, primary production is suppressed until the winds abate (e.g., Huntsman and Barber, 1977; Jones and Halpern, 1981). In contrast, Gulf Stream-induced upwelling increases stratification of the shelf and decreases the depth of the mixed layer as colder water intrudes onto the shelf beneath residence shelf waters. All of these differences will presumably influence the comparative efficiency and nature of the food chains that use phytoplankton production generated during wind-driven and Gulf Stream-induced upwelling. 
Speculation

During the 1979 and 1980 studies, some of the cross-shelf transects were extended seaward of the shelf break into the Gulf Stream. Chlorophyll isopleths contoured along these sections suggested continuity between subsurface chlorophy 11 maxima within the Gulf Stream and phytoplankton blooms within upwelled waters on the shelf. In general, chlorophyll isopleths followed isopycnals (isotherms) which, in turn, reflected the depth of the nitricline. Figure 18 illustrates an example where 4 diatoms that dominated upwelled waters on the shelf were the same 4 species that dominated the subsurface chlorophyll maximum within the cyclonic side of the Gulf Stream. In contrast, these 4 species were relatively unimportant within the shelf water shoreward of the phytoplankton bloom in upwelled waters (Fig. 18). From the results of single transects, one cannot conclude whether upwelling brings phytoplankton to the shelf or whether downwelling introduces shelf species to the subsurface chlorophyll maximum of the Gulf Stream. Results such as those presented in Figure 16 suggest that upwelling/downwelling causes an exchange of phytoplankton between blooms on the shelf and the subsurface chlorophyll maximum of the Gulf Stream. Marshall (1971) found that many phytoplankton species are common to the Gulf Stream and southeastern continental shelf and also suggested that upwelling along the front was a possible cause of the similarities. Dominate currents in the Gulf Stream are alongshelf implying that phytoplankton blooms within upwelled waters along the cyclonic side of the Gulf Stream may be "seeded" by phytoplankton transported long distances. For example, a current of $100 \mathrm{~cm} \mathrm{~s}^{-1}$ could transport a particle about $1000 \mathrm{~km}$ in 10 days. Studies in the Gulf of Mexico and Florida Straits identified upwelling zones that coincided with the location of the cyclonic front of the Gulf Stream (Loop Current) (Belousov et al., 1966). The dominant species within upwelled waters was the diatom, Thalassiosira subtilis, just as we observed in summer, 
197.8, and in other studies of upwelled GSW. Thus, we speculate that phytoplankton bloom dynmamics within upwelled waters along the Gulf Stream front in the Gulf of Mexico may be similar to the dynamics on the outer southeastern shelf, and that the strong currents associated with the Stream may have transported the population that "seeds" phytoplankton blooms within upwelled waters on the outer southeastern shelf a considerable distance.

Yentsch (1974, 1980) discussed the relatively high primary production observed along the cyclonic Gulf Stream front and attributed this to "ageostrophic effects" based on Rossby's (1936) model of cross-stream flow. Our studies suggest that frontal meanders and eddies may be the principal cause of the relatively high productivity of the cyclonic front, at least in those regions where the front is adjacent to continental shelves. We speculate that productivity of the cyclonic side of other western boundary currents, such as the Kuroshio, may also be influenced by similar processes. 


\section{ACKNOWLEDGEMENTS}

We thank the captains and crews of the R.V. Blue Fin, R. V. Eastward, R. V. James Gilliss, and R. V. Columbus Iselin for their assistance with the field studies. Special thanks to.C. Baker, W. Chandler; B. Christiansen, D. Deibel, D. Herring, G. Hess, F. Hudson, S. Lasley, P. 0!Malley, S. McIntosh, and J. Singer for technical assistance. We are especially grateful to H. Paerl for analyzing some of the $15 \mathrm{~N}$ samples, B. Giles for identification and enumeration of phytoplankton, A. Edwards for conducting some of the ${ }^{14} \mathrm{C}$ uptake experiments, and to $\bar{D}$. Menzel for critically reviewing a preliminary draft of this manuscript. This study was supported by U.S. Department of Energy contracts DE-AS09-76EV00936, OE-AS09-76EV00889, and DE-AS05-76EV05163 with partial ship support under NSF Grant OCE76-01142 and BLN Contract 209-05. 


\section{REFERENCES}

Atkinson, L. P. (1977) Modes of Gulf Stream intrusions into the South Atlantic Bight shelf waters. Geophysical Research Letters, 4, 583-586.

Atkinson, L.P. (1978) The results of four oceanographic cruises in the Georgia Bight. Georgia Marine Science Center, Skidaway Island, Georgia, Technical Report 78-1.

Atkinson, L. P., G. -A. Paffenhöfer, and W. M. Dunstan. (1978). The chemical and biological effect of a Gulf Stream intrusion off St. Augustine, Florida. Bulletin of Marine Science, 28, 667-679.

Belousov, I. M., Yu. A. Ivanov, S. A. Pasternak, T. S. Rass, and V. V. Rossov. (1966) Oceanographic research by the Soviet-Cuban marine expedition. Oceanology Açad. Sci. USSR, $6,312-320$.

Bishop, S. S., J. A. Yoder, and G. -A. Paffenhöfer. (1980) Phytoplankton and nutrient variability along a cross-shelf transect off Savannah, Georgia U.S.A. Estuarine and Coastal Marine Science, 11, 359-368.

Blanton, J. O., L. P. Atkinson, L. J. Pietrafesa, and T. N. Lee. (1981) The intrusion of Gulf Stream water across the continental shelf due to topographicallyinduced upwelling. Deep-Sea Research, 28A, 393-405.

Chandler, W. J., L. F. Atkinson, J. J. Jinger, P. G. O'Malley, and C. V. Baker. (1978) A CTD system: Description, operation, acquisition, and processing. Georgia Marine Science Center, Skidaway Island, Georgia, Technical report $78-7$.

Chew, F. (1981) Shingles, spin-off eddies and an hypothesis. Deep-Sea Research, $28 A, 379-391$.

Codispoti, L. A. and G. E. Friederich. (1978) Local and mesoscale influences on nutrient variability in the northwest African upwelling region near Cabo Corbeiro. Deep-Sea Research, 25, 751-770. 
Collos, Y. and J. Lewin. (1976) Blooms of surf-zone diatoms along the coast of the 0lympic Peninsula, Washington. 7. Variations of the carbon-to-nitrogen ratio in field samples and laboratory cultures of Chaetoceros armatum. Limnology and Oceanography, 21, 219-225.

Dugdale, R. C. and J. J. Goering. (1967) Uptake of new and regenerated forms of nitrogen in primary productivity. Limnology and Oceanography, $\underline{12}, 196-206$. Dunstan, W. M. and L. P. Atkinson. (1976) Sources of new nitrogen for the South Atlantic Bight. In: Eștuarine Processes, Vol.. 1, M. Wiley, editonr, Arademic Press, pp. 69-78.

Durbin, E. G., R. W. Krawiec, and T. J. Smayda. (1975) Seasonal studies on the relative importance of different size fractions of phytoplankton in Narragansett Bay (USA). Marine Biology, 32, 271-287.

Eppley, R. W., W. G. Harrison, S. W. Chisholm, and E. Stewart. (1977) Particulate organic matter in surface waters off southern California and its relationship to phytoplankton. Journal of Marine Research, 35, 671-696.

Eppley, R. W., E. H. Renger, and W. G. Harrison. (1979) Nitrate and phytoplankton production in southern California coastal waters. Limnology and Oceanography, 24, 483-494.

Glibert, P. L. and T. C. Loder. (1977) Automated analys is of nutrients in seawater: a manual of techniques. Woods Hole Oceanographic Institute, Technical report WHOI $-77-47$.

Haines, E. B. (1974) Processes affecting production in Genrgia conastal waters, Ph.D. Thesis, Duke University, $118 \mathrm{p}$.

Haines, E. B. and W. M. Dunstan. (1975) The distribution and relation of particulate organic material and primary productivity in the Georgia Bight 1973-1974 Estuarine and Coastal Marine Science, 3 , 431-441.

Hofmann, E. E., L. J. Pietrafesa, and L. P. Atkinson. (1981) A bottom intrusion in Onslow Bay, North Carolina. Deep-Sea Research, 28A, 329-345. 
Hofmann, E. E., L. J. Pietrafesa, J. M. Klinck, and L. P. Atkinson. (1980) A time-dependent model of nutrient distribution in continental shelf waters. Ecological Modeling, 10, 193-214.

Huntsman, S. A. and R. T. Barber. (1977) Primary production off northwest Africa: the relationship to wind and nutrient conditions. Deep-Sea Research, 24, 25-33.

Jones, B. H. and D. Halpern. (1981) Biological and physical aspects of a coastal upwelling event observed during March-April 1974 off northwest Africa. DeepSea Research, 28A, 71-81.

Kelley, J. C., T. E. Whitledge, and R. C. Dugdale. (1975) Results of sea surface mapping in the Peru upwelling system. Limnology and Oceanography, 20, 784794.

Kim, H. H., C. R. McClain, L. R. Blaine, W. D. Hart, L. P. Atkinson, and J. A. Yoder. (1980) Ocean chlorophyll studies from a U-2 aircraft platform. Journal of Geophysical Research, 도, 3982-3990.

Lee, T. N. (1975) Florida current spin-off eddies. Deep-Sea Research, 22, 753-765. Lee, T. N. and D. A. Brooks. (1979) Initial observations of current, temperature, and coastal sea level response to atmospheric and Gulf Stream forcing on the Georgia Shelf. Geophysical Research Letters, $\underline{6}, 321-324$.

Lee, T. N. and D. A. Mayer. (1977) Low-frequency current variability and spinoff eddies along the shelf off Southeast Florida. Journal of Marine Research, 35, $193-220$.

Lee, T. N., L. P. Atkinson, and R. Legeckis. (1981) Observations of a Gulf Stream frontal eddy on the Georgia continental shelf, April, 1977. Deep-Sea Research, 28A, $347-378$.

Malone, T. C. (1977) Light-saturated photosynthes is by phytoplankton size fractions in the New York Bight, U.S.A. Marine Biology, 42, 281-292. 
Marshall, H. G. (1971) Composition of phytoplankton off the southeastern coast of the United States. Bulletin of Marine Science, 21, 806-825.

O'Malley, P. G. (1981) The effect of summertime shelf break upwelling on nutrient flux in southeastern United States continental shelf waters. M.S. Thesis, Georgia Institute of Technology, $52 \mathrm{p}$.

Paasche, E. (1980) Silicon content of five marine plankton diatom species measured with a rapid filter method. Limnology and Oceanography, 25 474-480. Paffenhöfer, G. -A. (1980) Zooplankton diștributiọn as related to șummen hydrographic conditions in Onslow Bay, North Carolina. Bulletin of Marine Science, 30, 819-832.

Paffenhöfer, G. -A., D. Deibe1, L. P. Atkinson, and W. M. Dunstan. (1980) The relation of concentration of suspended particulate matter to hydrography in Onslow Bay, North Carolina. Deep-Sea Research , 27, 435-448.

Pietrafesa, L. J. and G. S. Janowitz. (1979) A note on the identification of a Gulf Stream spin-off eddy from Eulerian data. Geophysical Research Letters, $6,549-552$.

Rossby, C. -G. (1936) Dynamics of steady ocean currents in the light of experimental fluid mechanics. Papers in Physical Oceanography and Meteorology, 5, 3-43.

Sma11, L.. F. and D. W. Menzies. (1981) Patterns of primary productivity and biomass in a coastal upwelling region. Deep-Sea Research, 28A, 123-149.

Steemann Nielsen, E. (1952) The use of radioactive carbon $\left(C^{14}\right)$ for measuring organic production in the sea. J. du Cons. Internat. Explor. Mer., 19, $117-140$.

Strickland, J. D. (1958) Solar radiation penetrating the ocean. A review of requirements, data and methods of measurement, with particular reference to photosynthetic productivity. Journal of the Fisheries Research Board of Canada, 15, 453-493. 
Thomas, J. P. (1966) Influence of the Altamaha River on primary production beyond the mouth of the river. M.S. Thesis, University of Georgia, $88 p$.

Turner, R. E. (1981) Plankton productivity and the distribution of fishes on the southeastern U.S. continental shelf. Science, 206, 353-354.

Turner, R. E., S. W. Woo, and H. R. Jitts. (1979) Estuarine influences on a continental shelf plankton community. Science, 206, 218-220.

Vukovich, F. M., B. W. Crissman, M. Bushnell, and W. J. King. (1979) Gulf

Stream boundary eddies off the east coast of Florida. Journal of Physical Oceanography, $\underline{9}, 1214-1222$.

Walsh, J. J., T. E. Whitledge, J. C. Kelley, S. A. Huntsman, and R. D. Pillsbury. (1977) Further transition states of the Baja California upwelling ecosystem. Limnology and Oceanography, 22, 264-280.

Weber, A. H. and J. O. Blanton. (1980) Monthly mean wind fields for the South Atlantic Bight. Journal of Physical Oceanography, 10, 1256-1263.

Webster, F. (1961) A description of Gulf Stream meanders off Onslow Bay. Deep-Sea Research, $8,130-143$.

Yentsch, C. S. (1974) The influence of geostrophy on primary production. Tethys, 6, $111-118$.

Yentsch, C. S. (1980) Phytoplankton growth in the sea - a coalescence of disci-. plines. In: Primary productivity in the sea, P. G. Falkowski, editor, Plenum, pp. 17-32.

Yentsch, C. S. and D. W. Menzel. (1963) A method for the determination of phytoplankton chlorophyll and phaeophytin by fluorescence. Deep-Sea Research, 10, 221-231.

Yoder, J. A. (1979) Effect of temperature on light-limited growth and chemical competition of Skeletonema costatum (Bacillariophyceae). Journal of Phycology, 15, $362-370$. 
42

Yoder, J. A. (1980) Distribution of chlorophyll a in relation to hydrography and nutrients in the South Atlantic Bight. Report submitted to Science ApplicaLions, Inc., Raleigh, North Carolina, $38 \mathrm{p}$.

Yoder, J. A., L. P. Atkinson, J. 0. Blanton, D. R. Decibel, D. W. Menzel, and G. -A. Paffenhöfer. (1981) Plankton productivity and the distribution of fishes on the southeastern U.S. continental shelf. Science, 214, 352-353. Yoder, J. A., L. P. Atkinson, T. N. Lee, H. H. Kim, and C. R. McClain. (1981)

Role of Gulf Stream frontal eddies in forming phytoplankton patches on the outer southeastern shelf. Limnology and Oceanography, 26, 1103-1110. 
Table 1. Most abundant diatom species ( $\times 10^{-3}$ cells $\cdot l i t e r^{-1}$ ) at productivity station occupied on 28 April, 1979.

\begin{tabular}{|c|c|c|c|}
\hline SPECIES & 2 & $\begin{array}{r}\text { DEPTH } \\
12\end{array}$ & 45 \\
\hline \multicolumn{4}{|l|}{ DIATOMS } \\
\hline Chaetoceros spp. & 23 & 18 & n.d. \\
\hline Leptocylindrus danicus & 7 & 16 & 0.04 \\
\hline Nitzschia sp. & 27 & 72 & 0.18 \\
\hline Rhizosoleni'a fragilissima & 20 & 45 & 0.14 \\
\hline Rhizosolenia stolterfothii & 7 & 20 & 0.18 \\
\hline Skeletonema costatum & 96 & 350 & 0.20 \\
\hline TOTAL & . $\overline{195}$ & 570 & 1.3 \\
\hline \multicolumn{4}{|l|}{ DINOFLAGELLATES } \\
\hline TOTAL & n.d. & 9 & 0.04 \\
\hline
\end{tabular}


Table 2. Euphotic zone integrals of particulate and uptake measurements for shelfbreak productivity stations during Apri 1979 and 1980. See text.

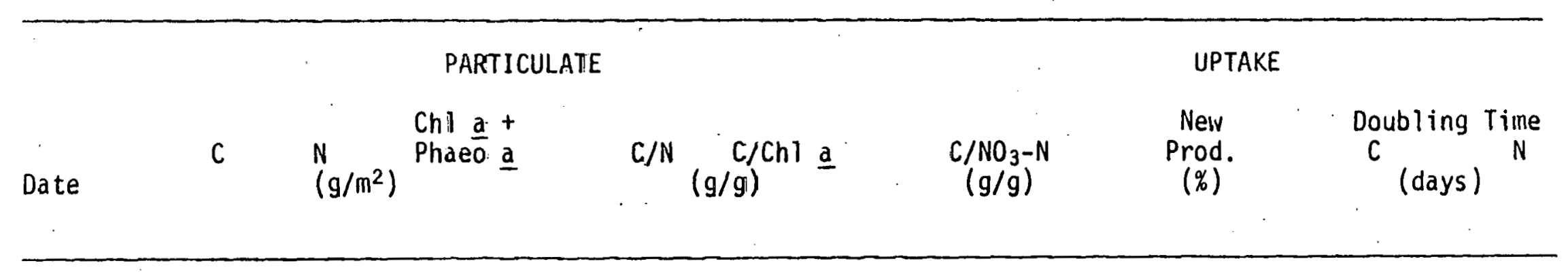

\begin{tabular}{|c|c|c|c|c|c|c|c|c|c|}
\hline \multicolumn{10}{|l|}{1979} \\
\hline $\begin{array}{l}4-23 \\
4-24 \\
4-27 \\
4-28 \\
4-29 \\
4-30\end{array}$ & $\begin{array}{r}13 \\
15 \\
8.3 \\
11 \\
8.4 \\
9.5\end{array}$ & $\begin{array}{r}1.4 \\
1.7 \\
0.72 \\
1.3 \\
0.83 \\
0.77\end{array}$ & $\begin{array}{l}0 . i 0 \\
0.06 \\
0.05 \\
0.09 \\
0.05 \\
0.06\end{array}$ & $\begin{array}{r}9.3 \\
8.8 \\
11 \\
8.5 \\
10 \\
12\end{array}$ & $\begin{array}{l}130 \\
250 \\
170 \\
120 \\
170 \\
160\end{array}$ & $\begin{array}{r}13^{\star} \\
23^{\star} \\
6.1^{\star} \\
17^{\star} \\
3.6^{\star}\end{array}$ & $\begin{array}{r}44^{\star} \\
25^{\star} \\
93^{\star} \\
34^{\star} \\
>100^{\star}\end{array}$ & $\begin{array}{l}3.4 \\
4.8 \\
6.9 \\
1.7 \\
4.9 \\
9.5\end{array}$ & $\begin{array}{l}-- \\
\cdots \\
-- \\
-- \\
-- \\
-\cdots\end{array}$ \\
\hline 1980 & & & & & & & & & \\
\hline $\begin{array}{l}4-12 \\
4-13 \\
4-17 \\
4-18 \\
4-20 \\
4-22 \\
4-26\end{array}$ & $\begin{array}{r}6.6 \\
9.9 \\
12 \\
9.8 \\
6.7 \\
7.6 \\
8.0\end{array}$ & $\begin{array}{l}1.2 \\
1.1 \\
1.0 \\
1.1 \\
0.8 \\
0.8 \\
0.9\end{array}$ & $\begin{array}{l}0.14 \\
0.03 \\
0.09 \\
0.10 \\
0.06 \\
0.03 \\
0.02\end{array}$ & $\begin{array}{r}5.5 \\
9.0 \\
12 \\
8.9 \\
8.4 \\
9.5 \\
8.9\end{array}$ & $\begin{array}{r}47 \\
330 \\
130 \\
98 \\
150 \\
250 \\
400\end{array}$ & $\begin{array}{r}11 \\
13 \\
8.0 \\
9.0 \\
6.3 \\
11 \\
6.3\end{array}$ & $\begin{array}{l}52 \\
44 \\
71 \\
63 \\
90 \\
52 \\
90\end{array}$ & $\begin{array}{r}18 \\
68 \\
16 \\
11 \\
3.5 \\
18 \\
22\end{array}$ & $\begin{array}{r}19 \\
100 \\
11 \\
11 \\
2.7 \\
22 \\
14\end{array}$ \\
\hline
\end{tabular}

*Based on measurements from onily 2 depths. 
Table 3. Estimates of percent POC not associated with phytoplankton (PP) and of the $\mathrm{C} / \mathrm{N}$ ratio $(\mathrm{g} / \mathrm{g})$ of non-phytoplankton particulates assuming that C/ChI a ratio of phytoplankton is either 50 or 100 and that phytoplankton $C / N$ ratio is either 5 or 10 . See text.

IF PP $\mathrm{C} / \mathrm{CHL} \underline{\mathrm{a}}=50$

Non-PP $C / N(g / g)$

Non-PP

$\operatorname{POC}(\%)$

\section{if $P P C / N$ is:}

5
IF PP C $/ \mathrm{CHL} \underline{\mathrm{a}}=100$

Non-PP

$\operatorname{POC}(\%)$
Non-PP $C / N(g / g)$ if $P P C / N$ is:

5

Apri1, 1979

RANGE

$59-80$

$11-38$

$7.6-14 \quad 18-60$

$5-21$

MEAN

(- high and low)

68

20

10

35

*

10

April, 1980

RANGE

$0-87$

10 -

7.4-*

$0-75$

$\star$

$3.5-*$

MEAN

(- high and low)

66

32

10

32

13

*Denotes that no $N$ is associated with non-phytoplankton particulates. 
Table 4. Daily change in the abundance ( $\times 10^{-3}$ cells.liter ${ }^{-1}$ except for I. Subtilis) of the dominant diatoms at the drague reference station during August, 1978. Species are ordered by their approximate cell volume.

\begin{tabular}{|c|c|c|c|c|c|c|c|c|c|c|c|}
\hline SPECIES & $\left(\times 10^{-3}{ }^{-3} \mathrm{~m}^{3}\right)$ & 0 & 1 & 2 & 3 & 4 & $\underset{5}{\text { DAYY of }}$ & $\begin{array}{l}\text { SAMPLE } \\
6\end{array}$ & 7 & 8 & 9 \\
\hline Cylindrotheca closterium & 0.1 & 0.1 & --- & $\cdots$ & --- & 8.8 & No & $-\cdots$ & No: & --- & -- \\
\hline Skeletonema costatum & 0.2 & ---- & --- & 9.2 & --- & 140 & Llata & $-\cdots$ & Data & $--\cdot$ & -- \\
\hline Thalassionema nitzchiodes & 0.4 & 0.06 & -- & 2.0 & $-\cdots-$ & 1.4 & & $-\cdots$ & & --- & $\cdots$ \\
\hline Chaetoceros spp. & 0.4 & 0.3 & 4.1 & 7.8 & 0.2 & 7.4 & & 0.2 & & 0.3 & 0.9 \\
\hline Leptocylindrus danicus & 3 & --- & 1.0 & 2.2 & ---- & 6.2 & & --- & & 0.6 & 0.4 \\
\hline Rhizosolenia fragilissima & 7 & --- & 1.3 & --- & $-\cdots$ & 6.4 & & $-\cdots$ & & 0.04 & 0.2 \\
\hline Cerataulina sp. & 40 & 0.9 & 1.8 & 3.4 & .0 .08 & 18 & & 0.06 & & 0.2 & 0.2 \\
\hline Rhizosolenia stolterfothii & 40 & 1.0 & 25 & 5.6 & 0.06 & 8.8 & & 0.2 & & 0.2 & 2.6 \\
\hline Rhizosolenia styliformis & 4000 & 0.4 & 1.2 & --- & 0.3 & $\cdots$ & & 0.3 & & 0.8 & 0.9 \\
\hline $\begin{array}{l}\text { Thalassiosira subtilis } \\
\text { (relative change) }\end{array}$ & . & 0.2 & -- & --- & 0.3 & 0.1 & & 3.2 & & 2.1 & 1.9 \\
\hline
\end{tabular}




\section{FIGURE LEGENDS}

Figure 1. Continental shelf off the north Florida, Georgia, and South Carolina coasts. Current meter moorings and primary production stations during the April, 1979 and 1980 studies and the net displacement of the drogue followed in August, 1978 are shown.

Figure 2. Wind vectors from shipboard measurements in April 1979 and 1980. During the gap in the 1979 record, winds were from the East shifting to the South at about $20 \mathrm{~m} \mathrm{~s}^{-1}$.

Figure 3. Time and depth changes in temperature at the 2 shelf break locations (5 $\mathrm{km}$ apart) where primary production measurements were made in Apri1, 1979. See Figure 1.

Figure 4. Vertical distributions in the euphotic zone at shelf break production stations occupied in Apri1, 1979. See Figure 1.

Figure 5. Temporal change in euphotic zone (A) $\mathrm{C}$ and $\mathrm{NO}_{3}-\mathrm{N}$ assimilation numbers, (B) $\mathrm{C}$ and $\mathrm{NO}_{3}-\mathrm{N}$ uptake, and (C) chlorophyll a and $\mathrm{NO}_{3}-\mathrm{N}$ for shelf break production stations occupied in April 1979 and 1980. See Figure 1.

Figure 6. Relative amount of daily sunshine during the three studies discussed in the text. Data from Jacksonville, Florida, meteorological station.

Figure 7. Time and depth changes in temperature and salinity at the locations of the production stations (along $30^{\circ} \mathrm{N}$ ) occupied in April, 1980 (A) $30 \mathrm{~m}$ isobath (B) $40 \mathrm{~m}$ isobath (C) shelf break. See Figure 1.

Figure 8. Vertical temperature $\left({ }^{\circ} \mathrm{C}\right)$ and $\mathrm{NO}_{3}(\mu \mathrm{M})$ sections across the shelf at $30^{\circ} \mathrm{N}$ during April, 1980. 
Figure 9.

Figure 10. Vertical distributions in the euphotic zone at shelf break production stations occupied in April, 1980. See Figure 1.

Figure 11. Temporal change in euphotic zone $\mathrm{C}$ uptake and $\mathrm{NO}_{3}-\mathrm{N}$ at (A) $30 \mathrm{~m}$ and (B) $40 \mathrm{~m}$ isobaths in Apri1, 1980. See Figure 1.

Figure 12. Euphotic zone C uptake versus mixed layer chlorophyll a. Data from shelf break stations during. upwelling in April 1978, 1979, and 1980.

Figure 13. Temperature sections centered at the position of the drogue followed in August, 1978. See Figure 1.

Figure 14. Time and depth changes in chlorophyll a and $\mathrm{NO}_{3}$ at the drogue reference station during August, 1978.

Figure 15. Temporal change in mean intrusion $\mathrm{NO}_{3}$ and chlorophyll a at the drogue reference station. Lines illustrate 2 different rates (base 2) of exponential decrease for $\mathrm{NO}_{3}$ and 2 different rates of exponential increase for chlorophyll $\underline{a}$.

Figure 16. Representative (best and worst linear correlation coefficients) photosynthesis versus irradiance measurements from water samples collected from within the subsurface intrusion at the drogue reference station during August, 1978.

Figure 17. Chlorophyll a versus particulate Si concentration from samples collected within the subsurface intrusion during the drogue study in August, 1978. 
Figure 18. Outer shelf temperature section, vertical chlorophyll a distribution and dominate diatom species at selected stations on the outer shelf during April, 1979. Inshore edge of the Gulf Stream is delineated by the $23^{\circ} \mathrm{C}$ isotherm. Arrows indicate depth at which species composition was determined. 
Fig 1

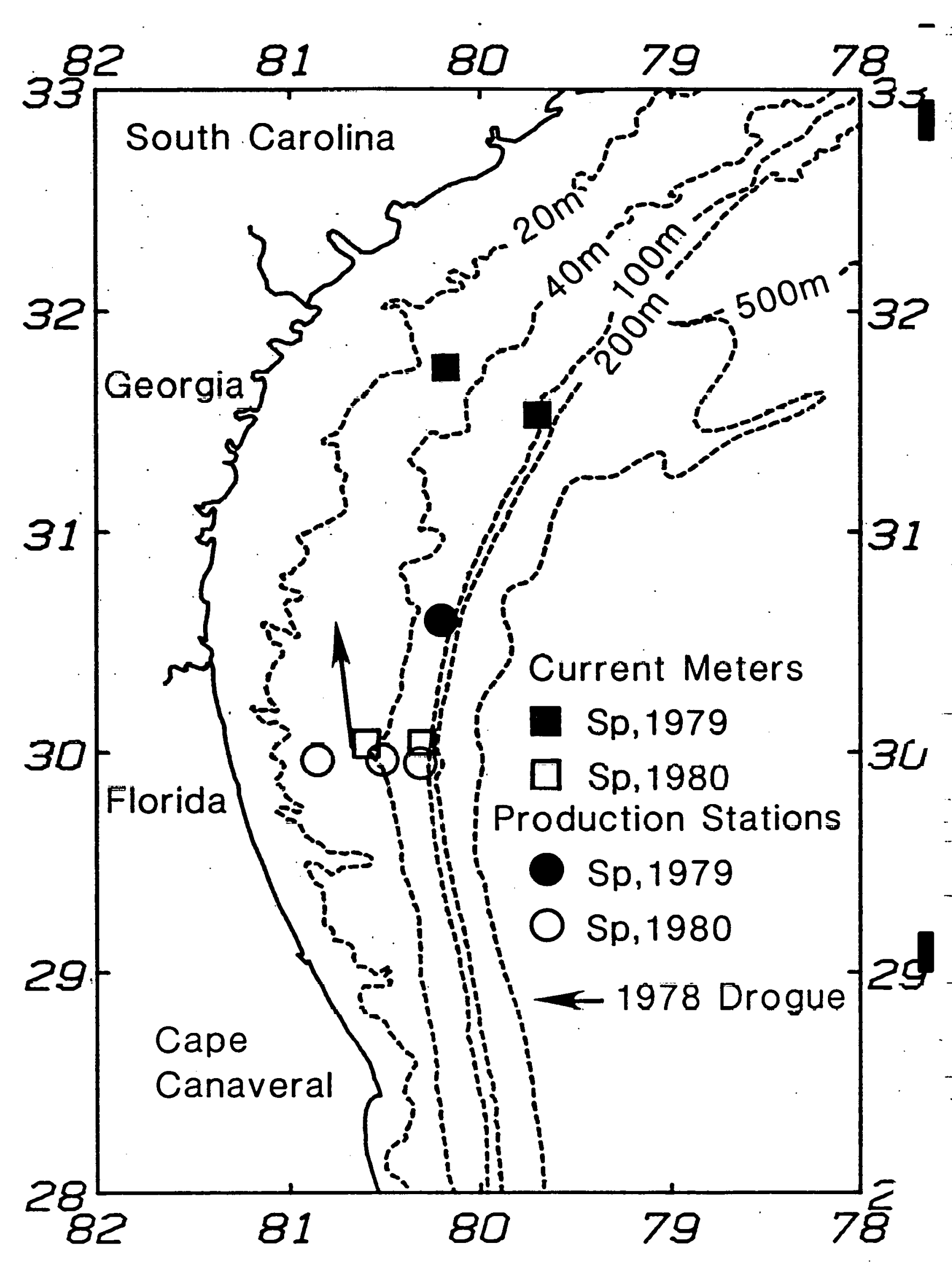


Fig 2
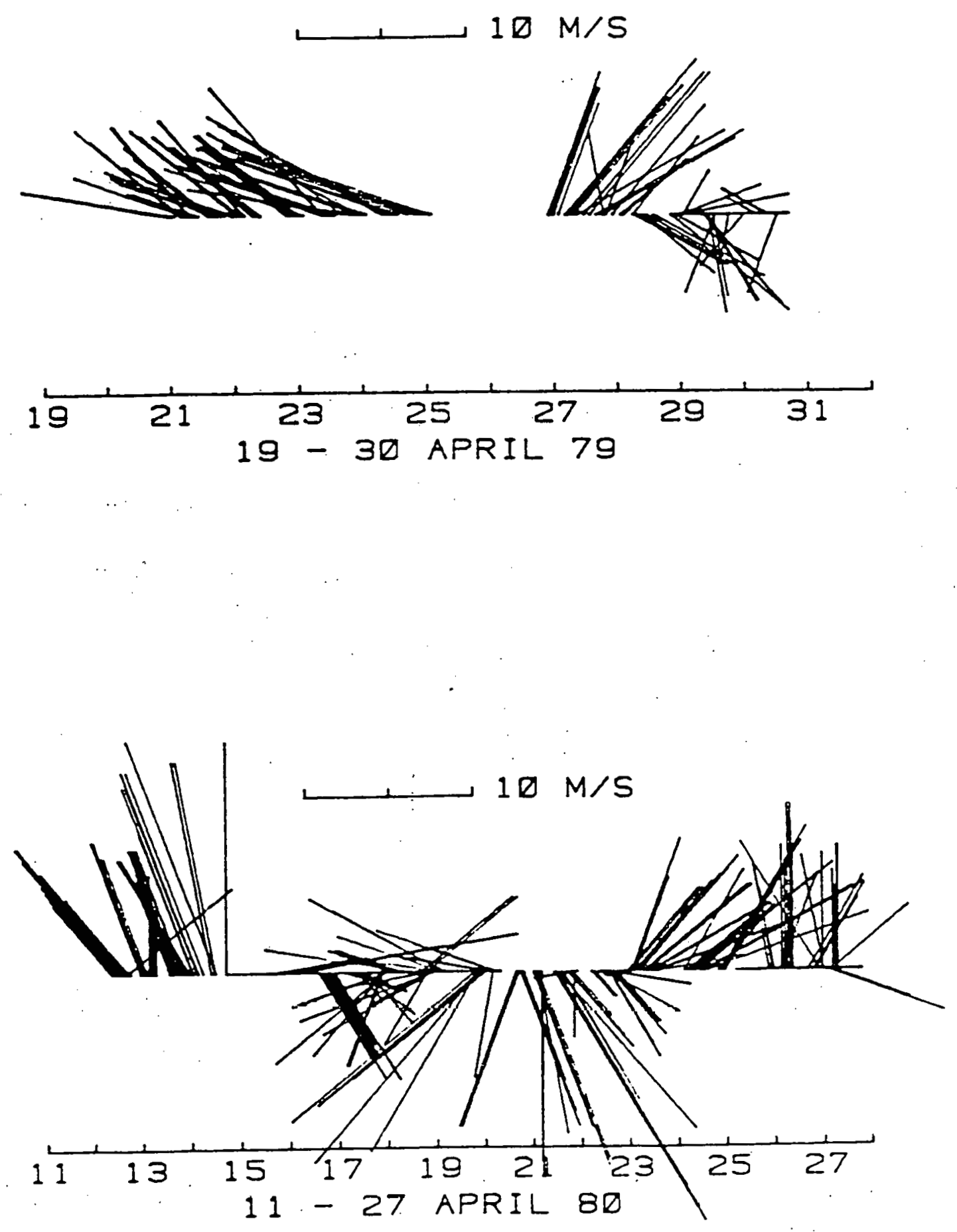


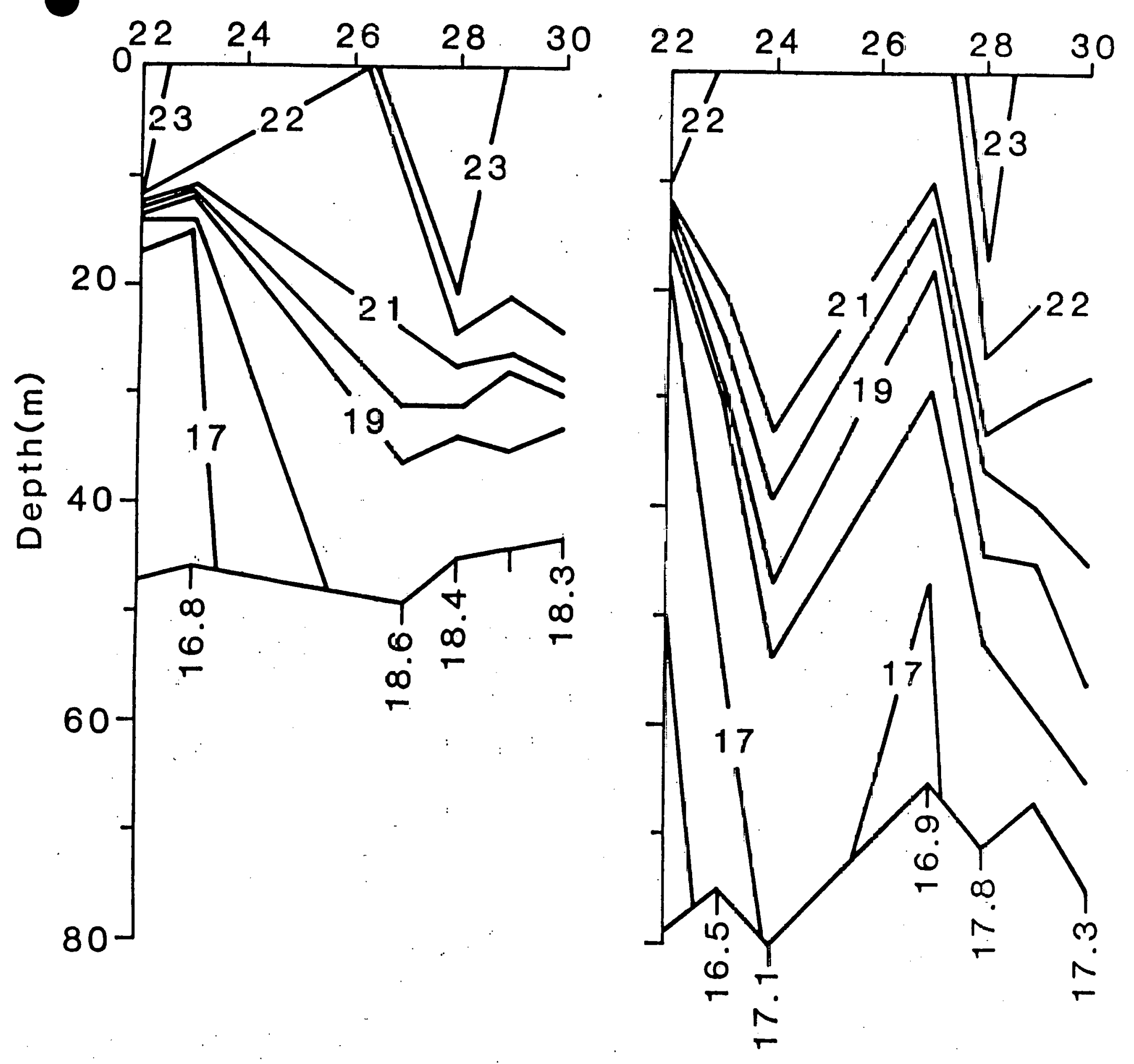


Fig 4

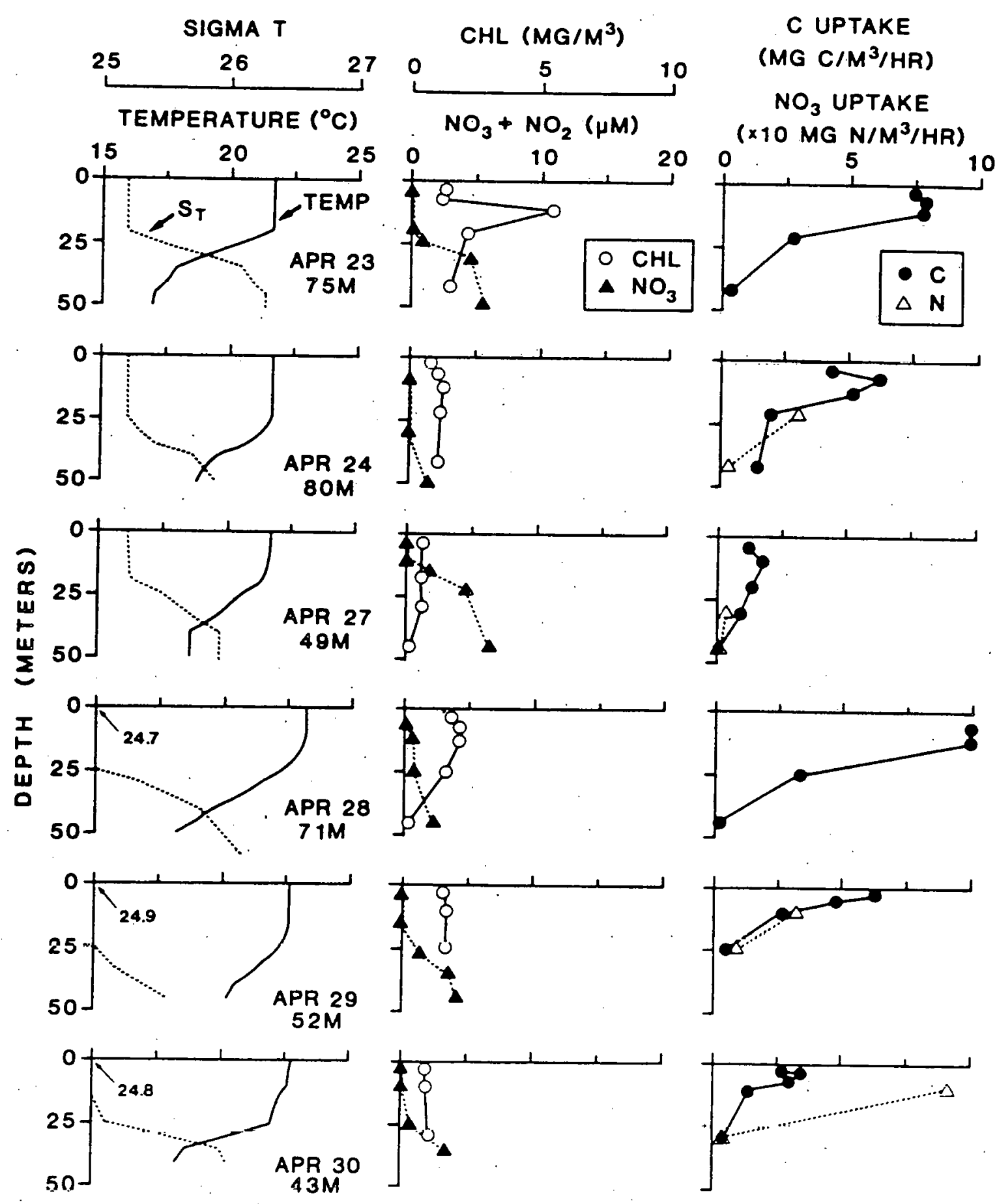


Fig. 5
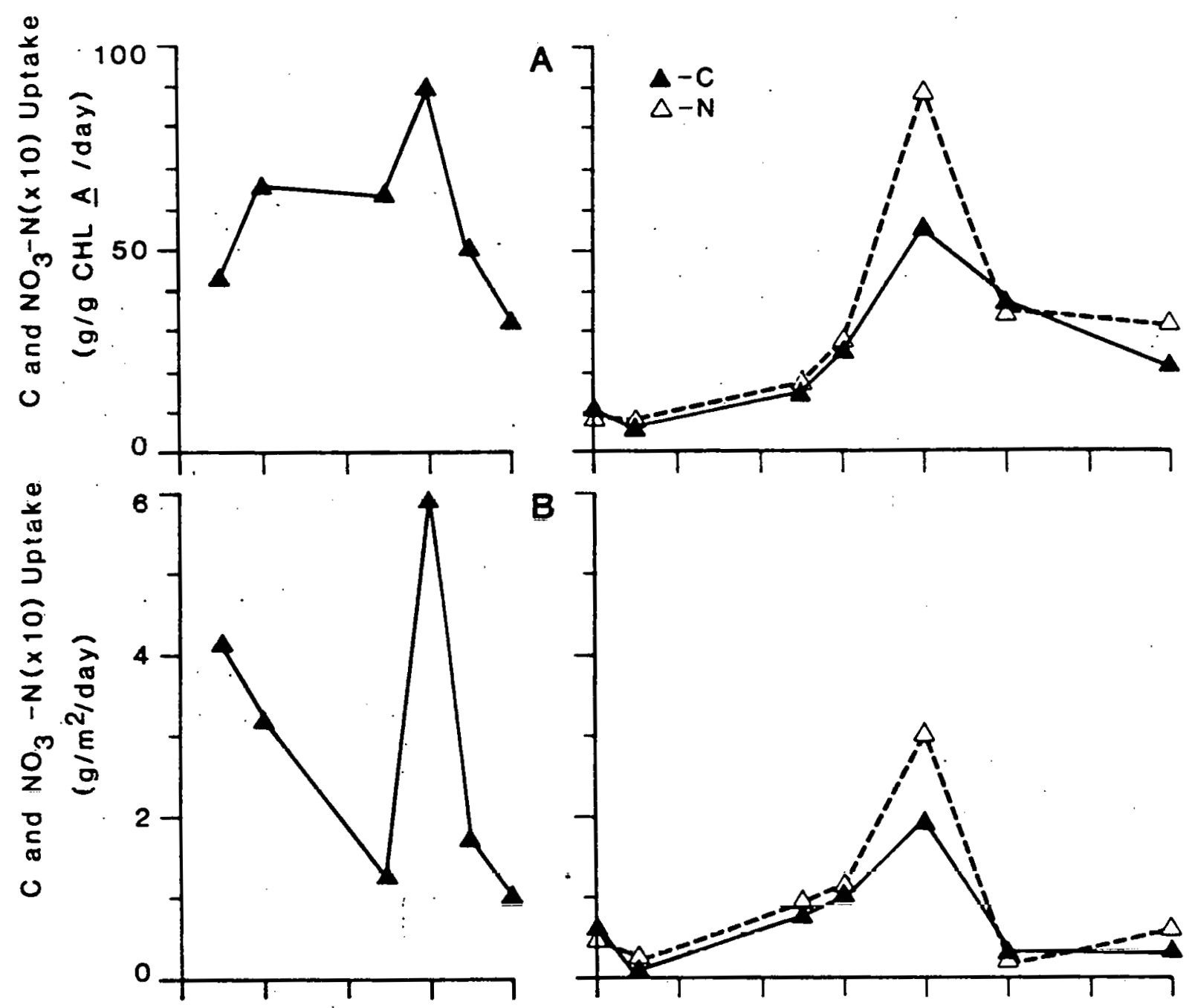

8
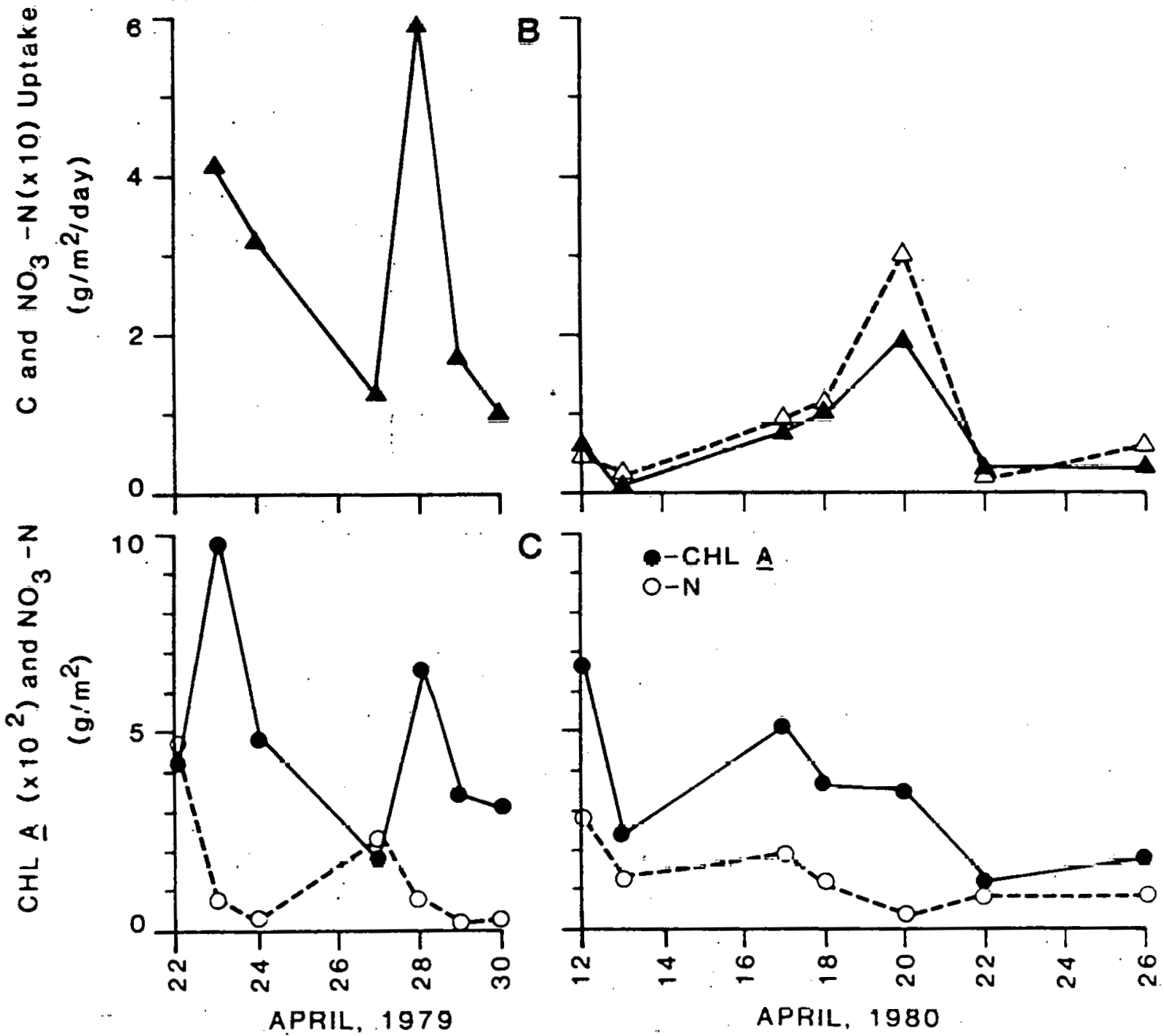

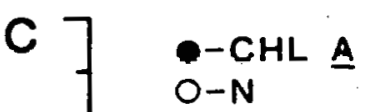

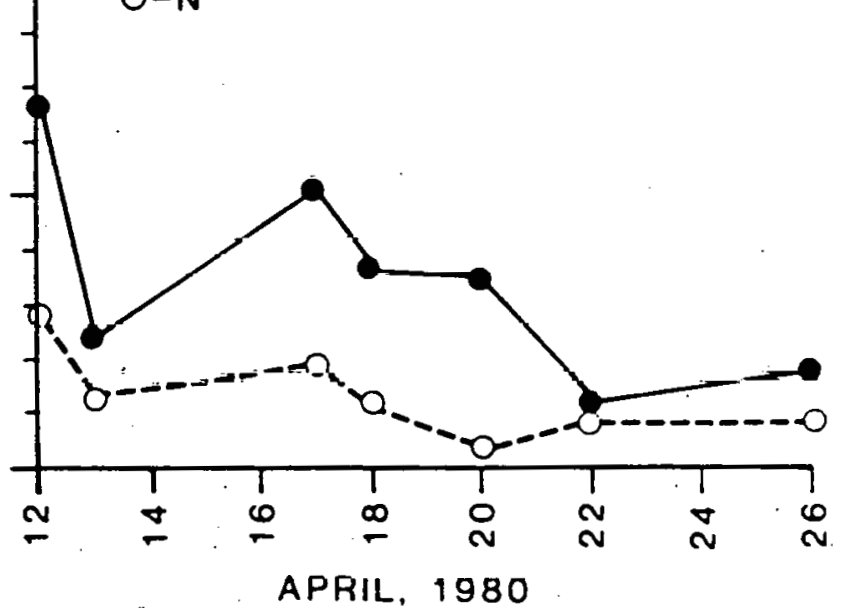


$19-56$

Fig 6
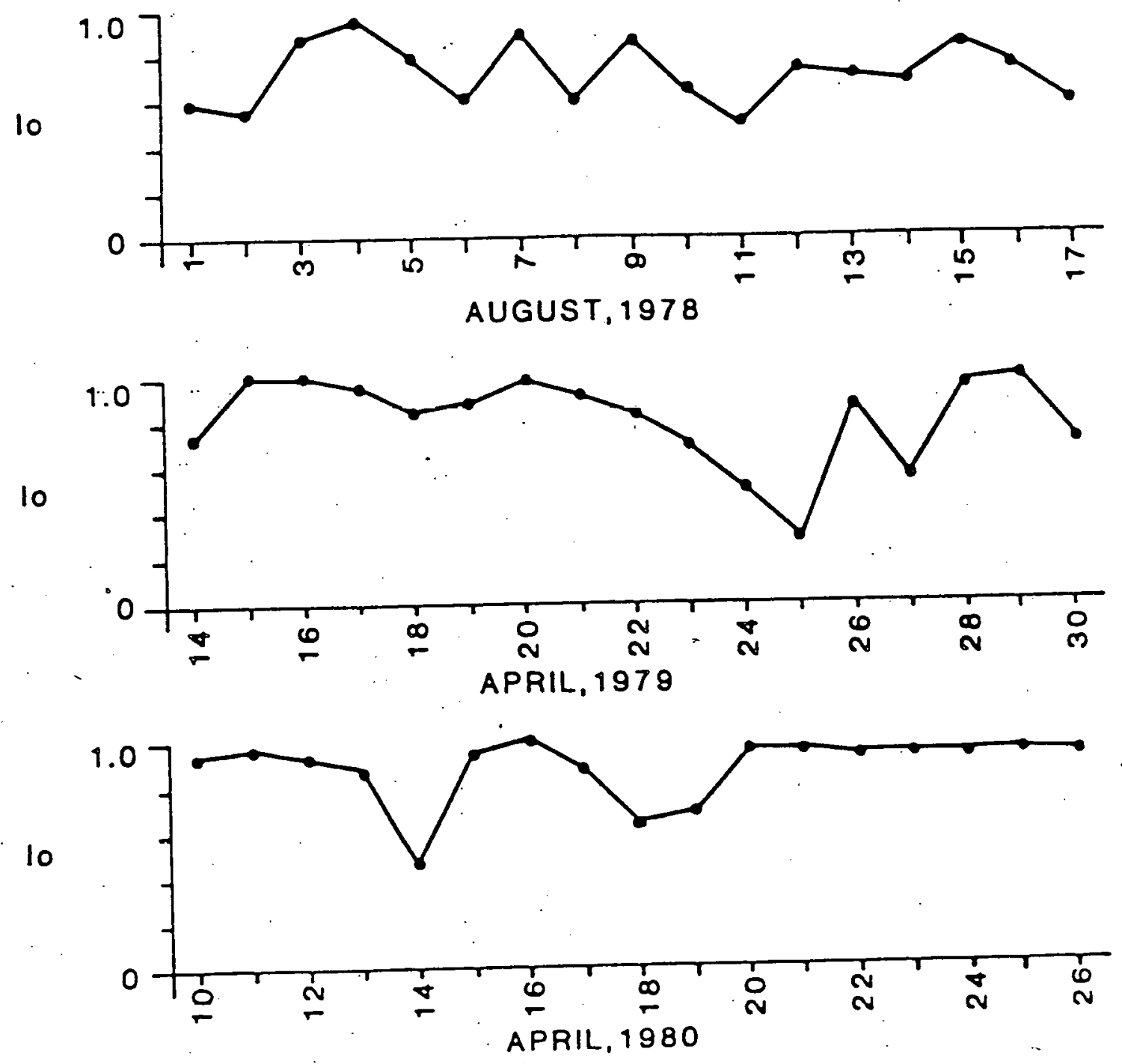
Fig 7

APRIL, 1980
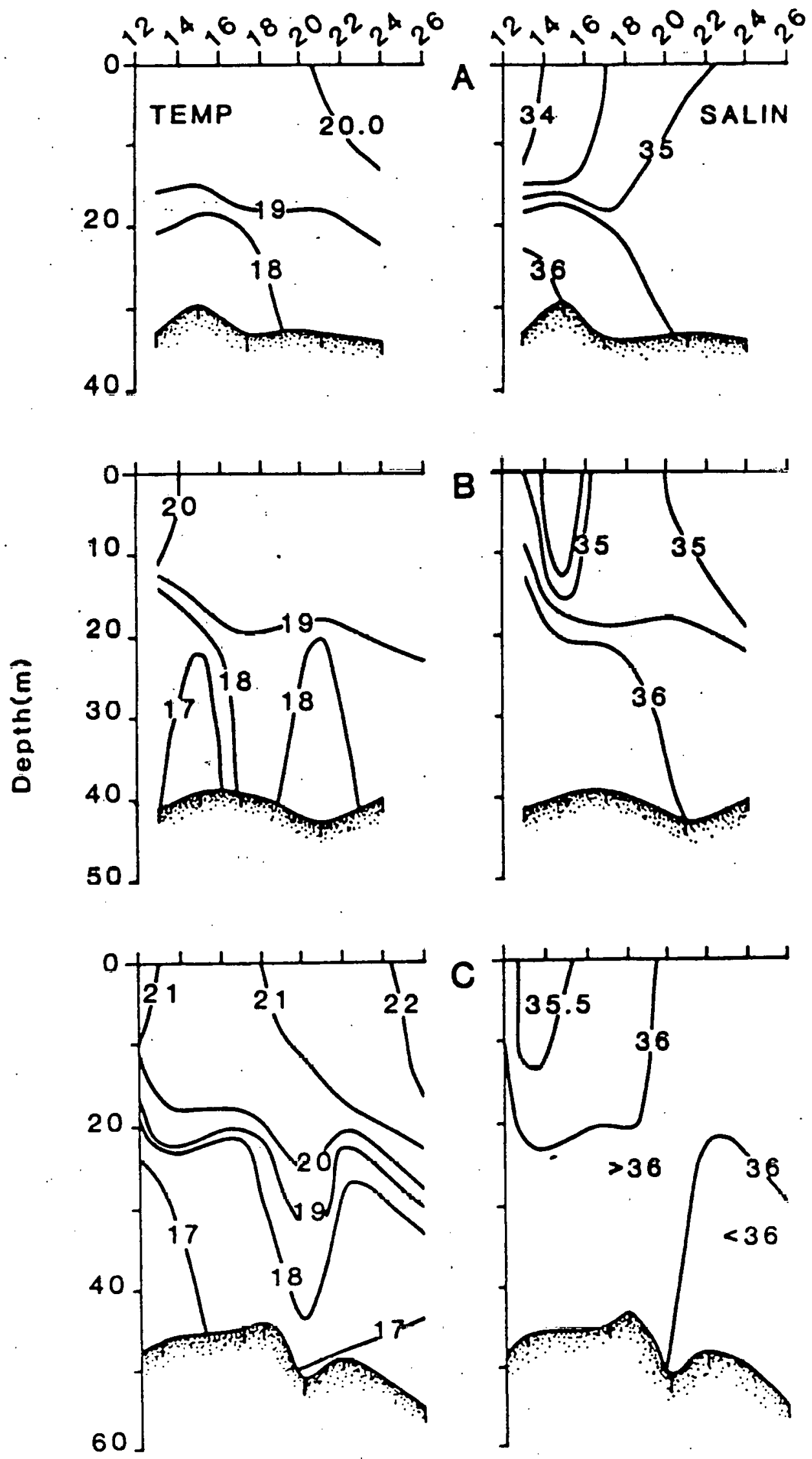
Fig 8
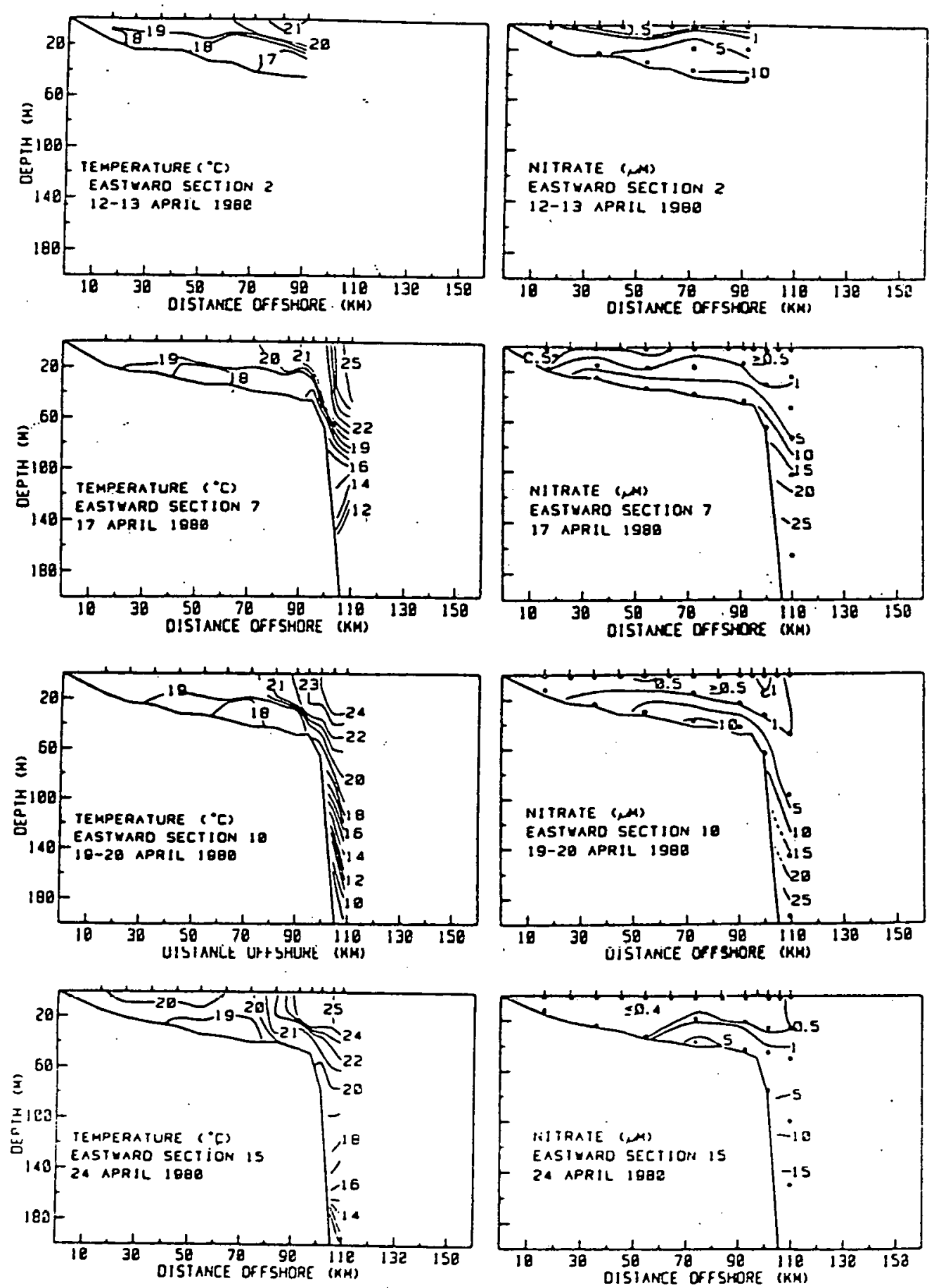
Fig 10

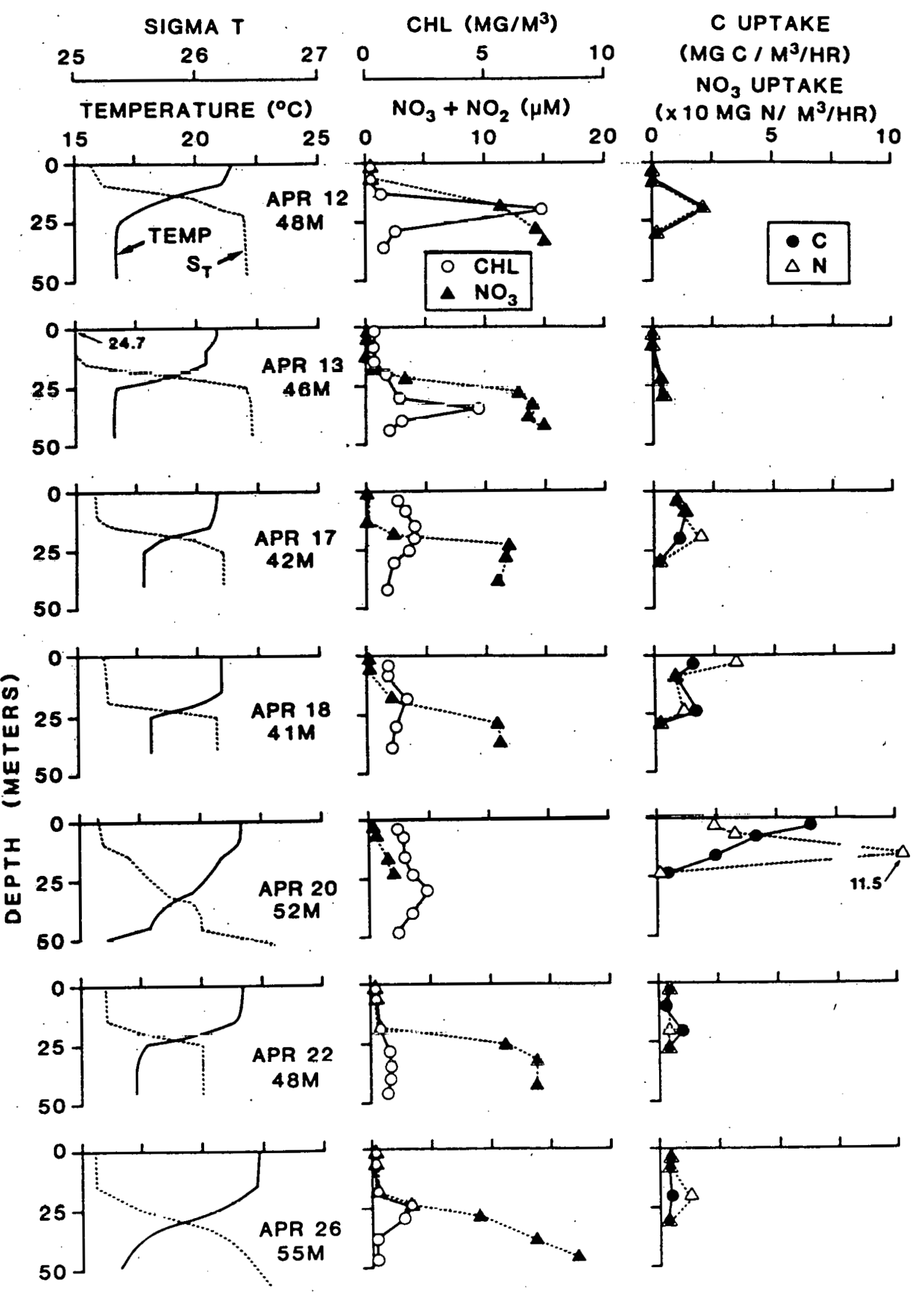


Fig 11

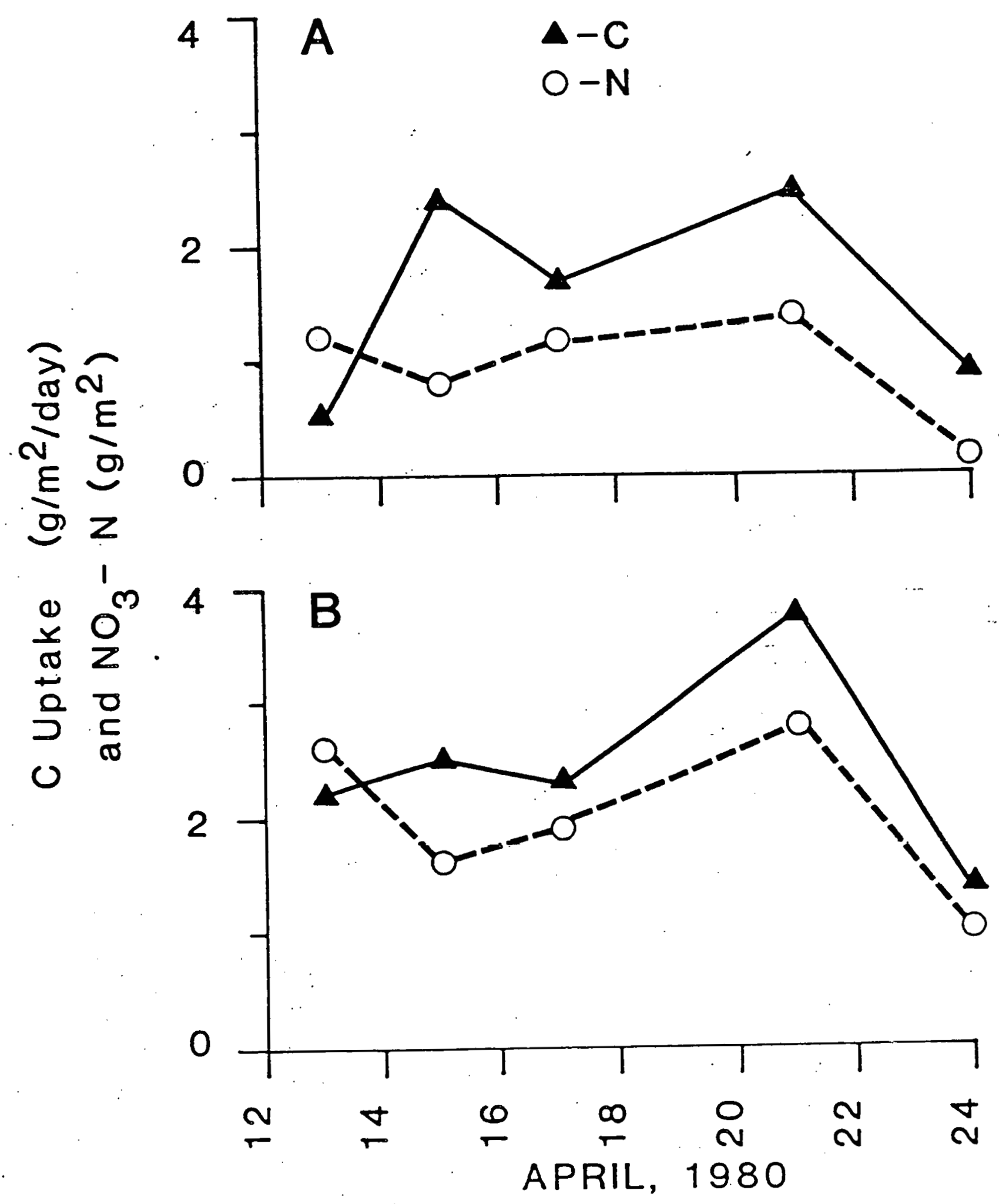


Fig 12

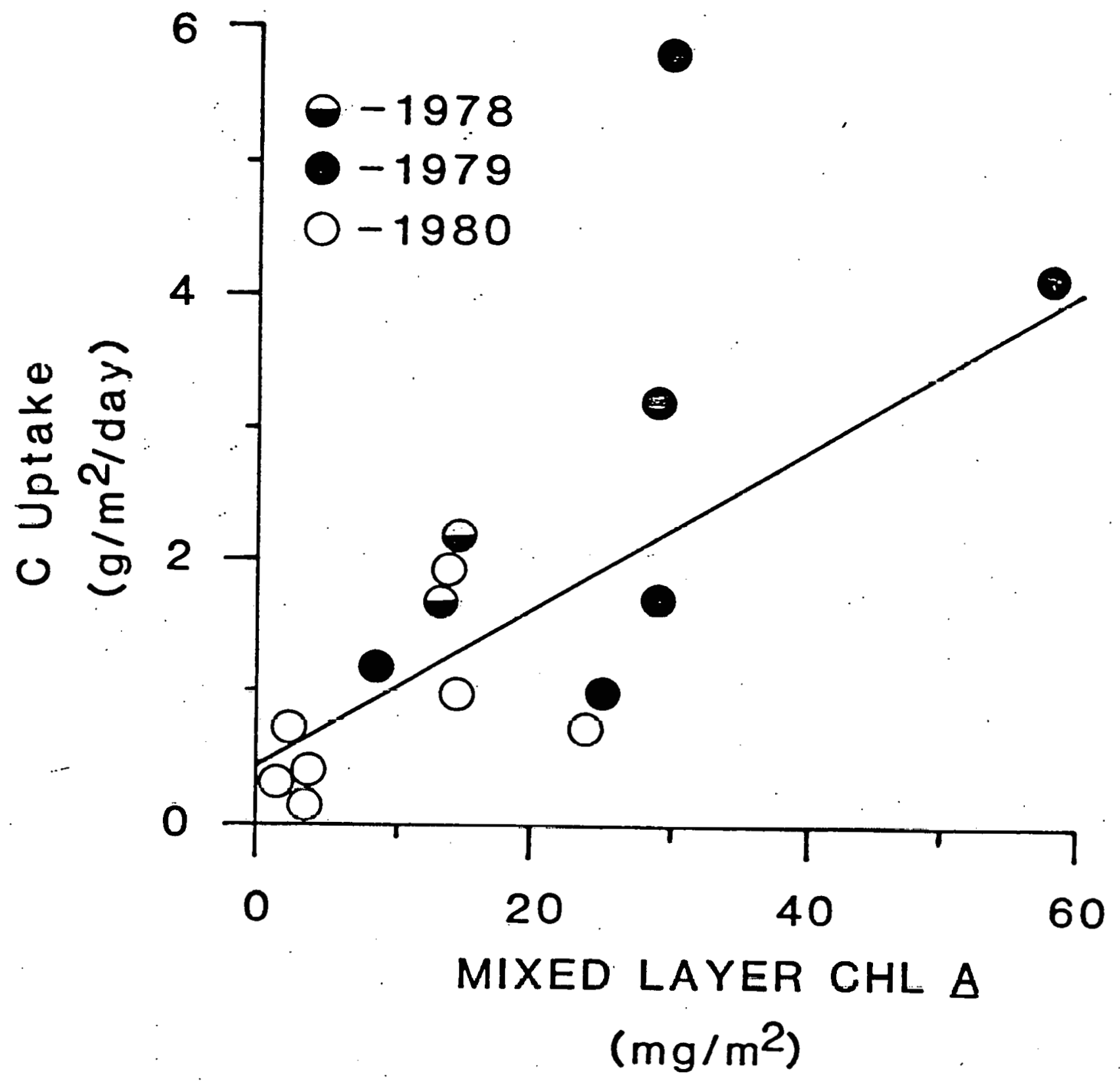




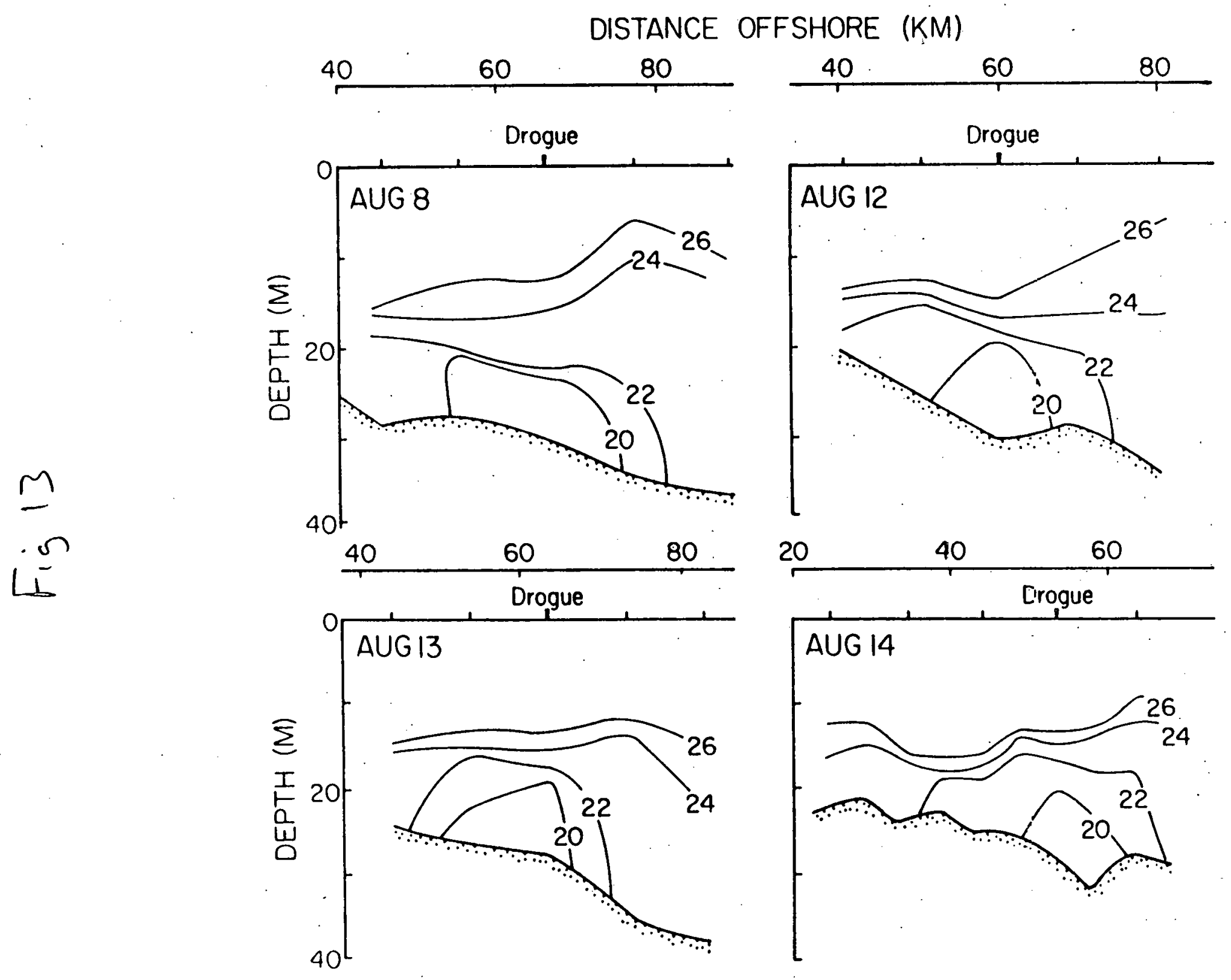




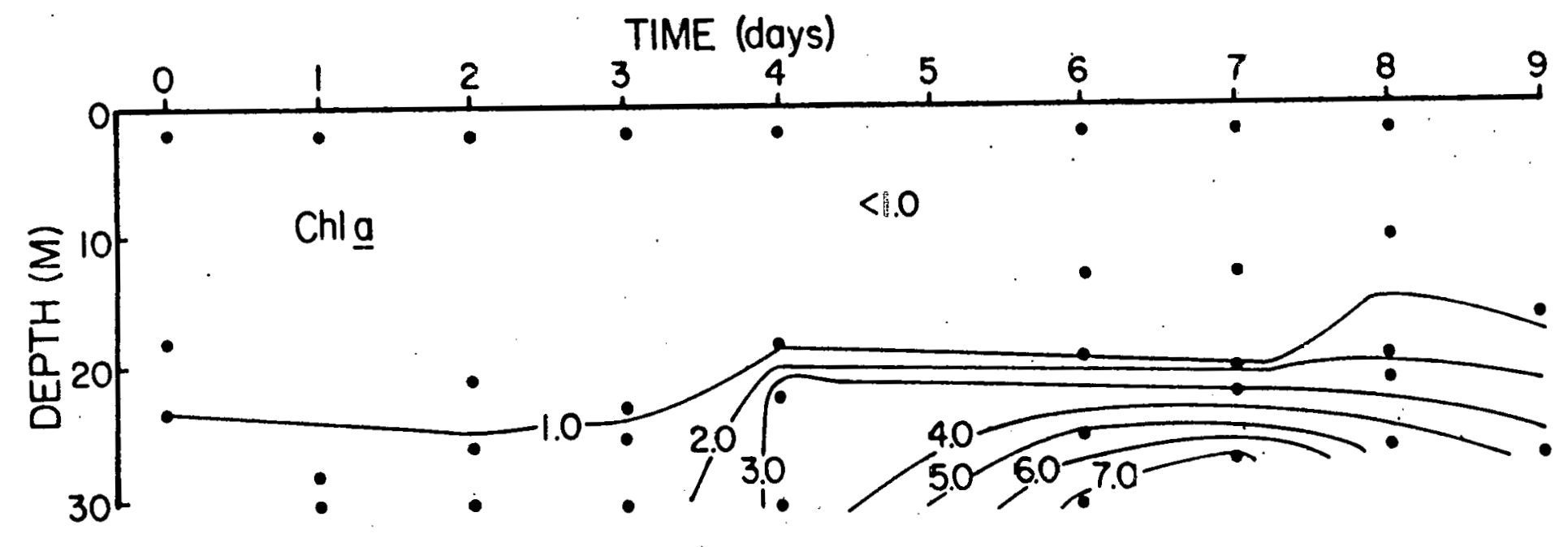

$\underline{4}$

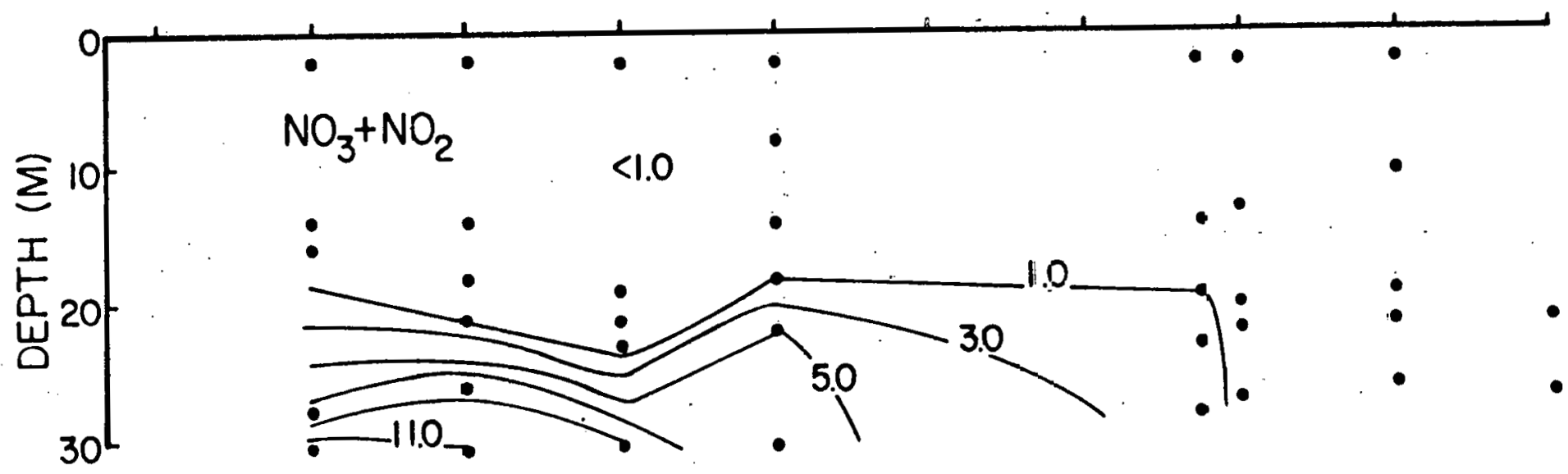


Fig 15
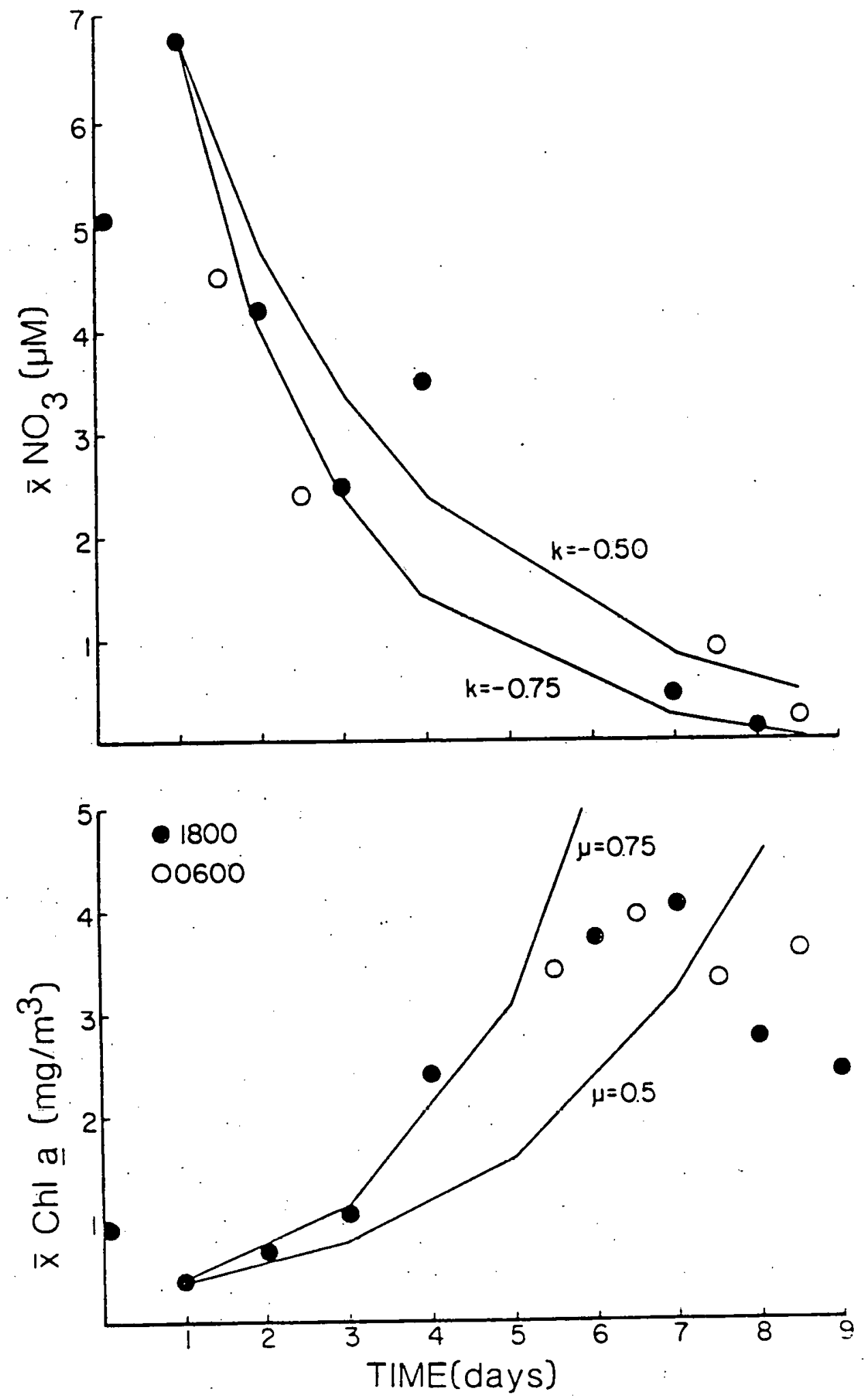
$F_{19}{ }^{16}$

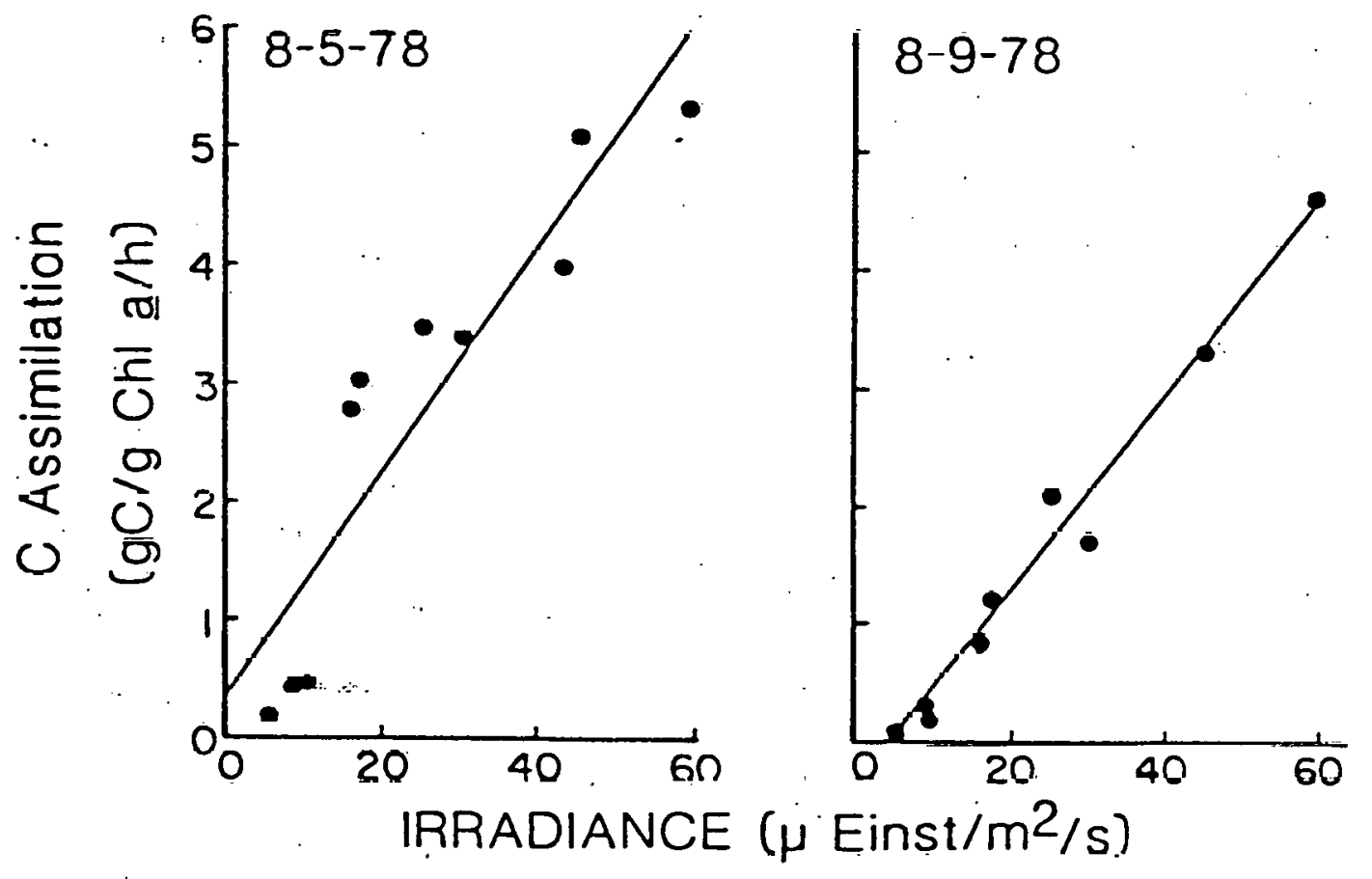


Fig 1?

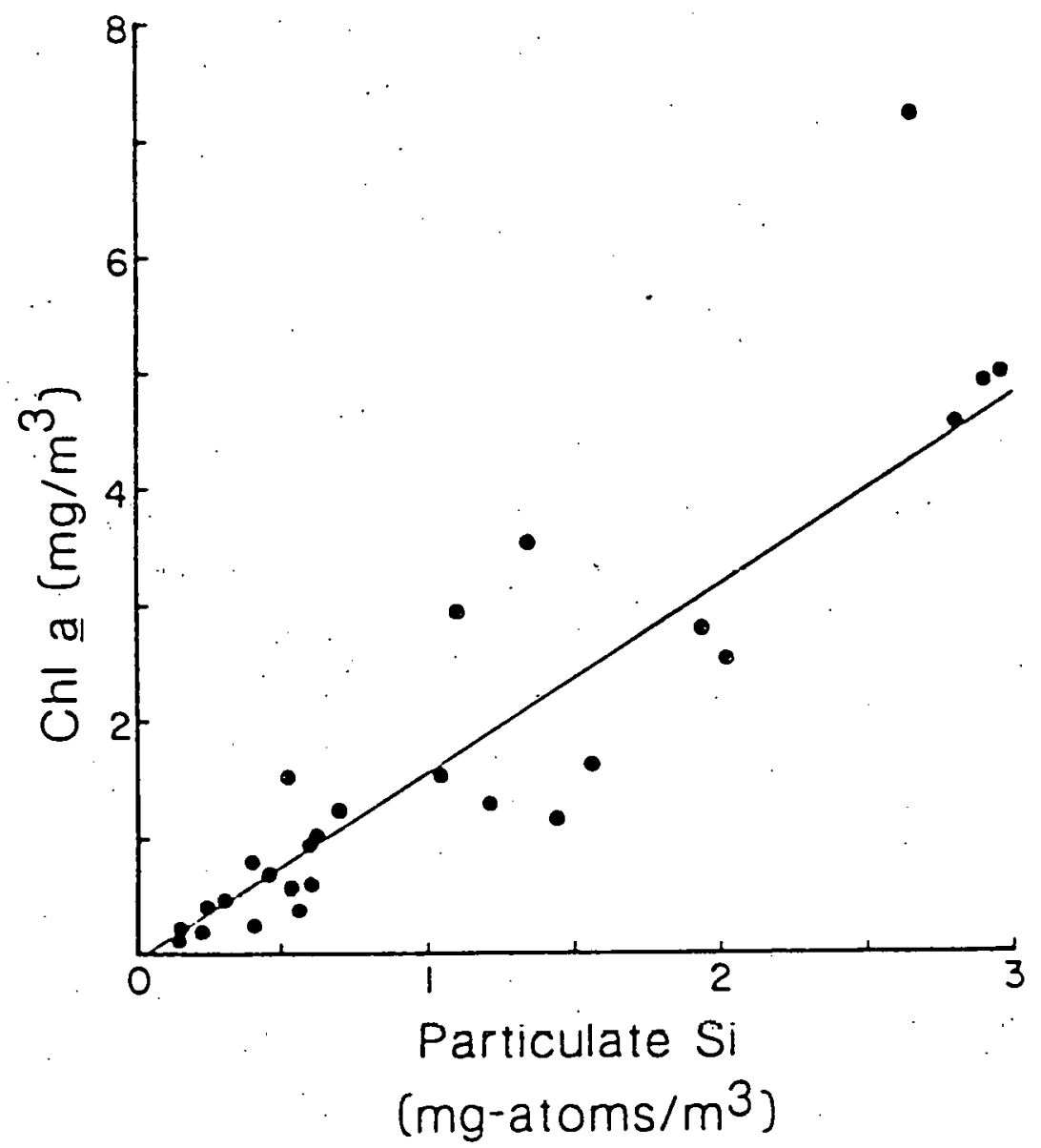


DISTANCE OFFSHORE (Km)

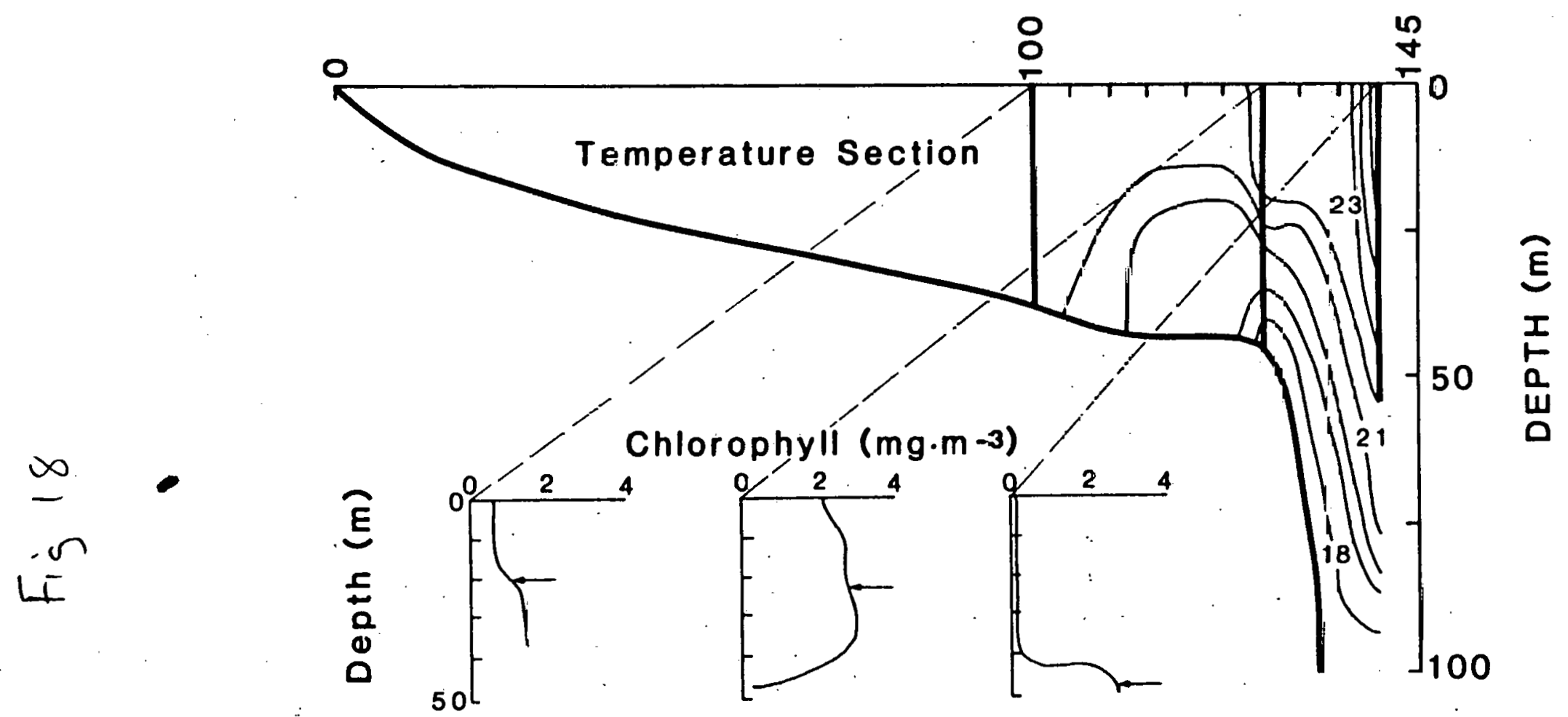

\section{Species Composition (\%)}

S. Costatum

Chaetoceros sp.

Nitzschia sp.

R. Iragilissima

15
3
8
0

52

14

8
60

21

8 


\section{ACKNOWLEDGEMENTS}

This research was supported in full by U.S. Department of Energy Contract Number DE-AS09-76EV00936. 